\title{
New mindsets to innovate activation
}

\author{
Citation for published version (APA):
}

Bierbaum, M. (2019). New mindsets to innovate activation. [Doctoral Thesis, Maastricht University]. ProefschriftMaken. https://doi.org/10.26481/dis.20191030mb

Document status and date:

Published: 01/01/2019

DOI:

10.26481/dis.20191030mb

Document Version:

Publisher's PDF, also known as Version of record

\section{Please check the document version of this publication:}

- A submitted manuscript is the version of the article upon submission and before peer-review. There can be important differences between the submitted version and the official published version of record.

People interested in the research are advised to contact the author for the final version of the publication, or visit the DOI to the publisher's website.

- The final author version and the galley proof are versions of the publication after peer review.

- The final published version features the final layout of the paper including the volume, issue and page numbers.

Link to publication

\footnotetext{
General rights rights.

- You may freely distribute the URL identifying the publication in the public portal. please follow below link for the End User Agreement:

www.umlib.nl/taverne-license

Take down policy

If you believe that this document breaches copyright please contact us at:

repository@maastrichtuniversity.nl

providing details and we will investigate your claim.
}

Copyright and moral rights for the publications made accessible in the public portal are retained by the authors and/or other copyright owners and it is a condition of accessing publications that users recognise and abide by the legal requirements associated with these

- Users may download and print one copy of any publication from the public portal for the purpose of private study or research.

- You may not further distribute the material or use it for any profit-making activity or commercial gain

If the publication is distributed under the terms of Article $25 \mathrm{fa}$ of the Dutch Copyright Act, indicated by the "Taverne" license above, 


\title{
New Mindsets
}

\author{
to Innovate Activation
}

Mira Bierbaum 
The cover illustration by Alexander Engel is inspired by the bronze sculpture L'homme qui marche I (The Walking Man I) created by Swiss artist Alberto Giacometti in 1961.

Giacometti's sculpture embodies the fragility of human life and the vulnerability that inevitably accompanies our being and that deserves society's unconditional protection. At the same time, there is a forward moving, unbroken element that depicts the life force of man, representing the often amazing resilience that we can see when we look around us attentively and with empathy. This aspect equally deserves our attention and recognition.

The use of chalk as the medium for the drawing, in combination with an expressive style, mimics the rough and raw appearance of the sculpture, while adding additional highlights and thereby depicting the many facets that define our identity and make us unique human beings. The repeated silhouette of the sculpture is used to form the stylised iris in the background. The iris therefore symbolises both the aspiration of this thesis - to zoom in and deconstruct implicit assumptions - as well as its attention to the way in which an individual is embedded in the social fabric.

Cover Design: Alexander Engel.

Publisher: ProefschriftMaken || www.proefschriftmaken.nl ISBN: 978-94-6380-527-8.

Copyright (C) Mira Bierbaum, 2019.

All rights reserved. No part of this publication may be reproduced, stored in a retrieval system, or transmitted in any form, or by any means, electronic, mechanical, photocopying, recording or otherwise, without the prior permission in writing, from the author. 


\title{
New Mindsets \\ to Innovate Activation
}

\author{
DISSERTATION
}

To obtain the degree of Doctor at Maastricht University on the authority of the Rector Magnicus, Prof. Dr. Rianne M. Letschert, in accordance with the decision of the Board of Deans, to be defended in public on

Wednesday, 30 October 2019, at 14.00 hours

by

Mira Bierbaum 


\section{Supervisors}

Prof. Dr. Fred Zijlstra

Prof. Dr. Franziska Gassmann

Prof. Dr. Ir. Eleonora Nillesen

\section{Assessment Committee}

Prof. Dr. Andries de Grip (Chair)

Prof. Dr. Jan Vranken, University of Antwerp

Dr. Rik van Berkel, Utrecht University

Dr. Zina Nimeh 


\section{Acknowledgments}

This thesis is the result of hard work, but much more than that, it is a great gift that has influenced my professional and personal trajectory over the last few years and certainly will do so into the future.

I would like to thank the assessment committee, Andries de Grip, Jan Vranken, Rik van Berkel and Zina Nimeh, who took the time to read my thesis and to provide valuable and insightful comments that improved its quality. I am thankful to my supervision team that has accompanied me for the last few years. Franziska Gassmann was the reason why I started this project in the first place. I have greatly appreciated the balance that she helped me strike between the freedom to explore new avenues, while not losing focus. Franziska is also the person who made it possible to conduct this research at Sociale Zaken Maastricht Heuvelland. With her superior analytical skills, Lonneke Nillesen supported me in sharpening my thinking and arguments. She also showed me how a story is created around an academic puzzle. Fred Zijlstra did not only support me in including a psychological angle in this research, but I also admire his dedication to improving the well-being of people in Limburg who have not enjoyed the best opportunities from the outset.

I am indebted to all citizens and caseworkers who participated in my research. In particular, I was touched by the openness of my interview partners who decided to share their stories. This was greatly facilitated by my interviewer Jàchyne Dejong, who struck the perfect balance between empathy and professionalism. Furthermore, I would like to thank all neighbourhood centres in Maastricht where we conducted interviews.

I am very grateful for the doctoral scholarship that I received by the Studienstiftung des deutschen Volkes, as this financial freedom directly translated into more academic freedom. This research was also made possible through the financial support of Sociale Zaken Maastricht Heuvelland. In addition to this, my special thanks go to Richard Vleugels and Manon Derrez for their generous support both in terms of their thinking and dedicating time. My thanks extend to the directors of Sociale Zaken Maastricht Heuvelland, Jellemiek Zock-ten Hoor in the first instance and later Nardy Beckers, the participation manager Huub Seyben, Resi Janssens and Uschi Hermans for their administrative support, the quality assurance employees Ruth Israël and Chantal Vandewalle, and, by way of example only, the caseworkers Harry Golsteijn, Minou Goessens, and Rachèl Ruijters, who piloted different studies. 
Many thanks go also to Robert Doyen who checked that survey instruments were written in plain language to increase accessibility.

From the side of UNU-MERIT and MGSoG, I received generous support from many people, be it administratively, academically, or through their moral support. I would like to thank Danny Beckers, Eveline in de Braek, Sueli Brodin, Mieke Drossaert, Ingeborg Eijssen-de Beer, Eric Engelen, Marlies Haak, Mourik Jan Heupink, Howard Hudson, Liesbeth Noben, Ad Notten, Herman Pijpers, Susan Roggen, Ingrid Scheffers, Muriël Verseijden, Marc Vleugels, Kim Zancan, my PhD cohort, colleagues and office mates, and the directors of the $\mathrm{PhD}$ programme Robin Cowan, Tatiana Skripka and formerly Mindel van de Laar. I especially benefitted from discussions with Keetie Roelen and Stefania Innocenti throughout my thesis.

This research is firmly based on the sincere conviction that "everyone, as a member of society, has the right to social security" (Universal Declaration of Human Rights, 1948, article 22). I am greatly indebted to Michael Cichon, who was the first person who exposed me to this idea. Together with Franziska Gassmann and Zina Nimeh, he ignited my commitment to social protection. Michael also introduced me to exciting projects beyond this PhD. I would like to thank Cäcilie Schildberg from the Friedrich-Ebert-Stiftung and Shahra Razavi and Laura Turquet from UN Women for giving me the opportunity to work with them and Michael during my $\mathrm{PhD}$ research.

I am thankful to my paranymphs, Peggy Muijrers and Vu Thao-Vi Dao, who do not only support me today, but have done so for the last few years. Alexander Engel prepared the cover with a lot of creativity, skills and patience. Sophie Bathurst shared her gift for languages and worked with me on making this thesis a book that is hopefully worthwhile reading, not only because of the content.

I dedicate this work to my family. I thank them for having afforded me the privilege of growing up in an environment of unconditional love where I could explore different opportunities, get lost and sometimes fail, and make the most of my capabilities. 


\section{Contents}

Acknowledgments $\quad$ i

1 Introduction $\quad 1$

1.1 Background and Motivation . . . . . . . . . . . . . . . . . 1

1.2 Sequential Exploratory Research Design . . . . . . . . . . . . . . . 9

1.3 Key Terms and Thesis Outline . . . . . . . . . . . . . . . . . 13

1.4 Ethical Considerations . . . . . . . . . . . . . . . . . 18

References ....................... 20

2 Activation, Societal Participation, and Work: Expansion and $\begin{array}{ll}\text { Limits of Substantive Freedoms } & 27\end{array}$

2.1 Introduction . . . . . . . . . . . . . . . . . . . . . 27

2.2 Conceptual Framework: Activation, Capabilities, and Social Exclusion 29

2.3 Policy Context . . . . . . . . . . . . . . . . . . . . . 33

2.4 Research Method . . . . . . . . . . . . . . . . . . . 36

2.5 Findings . . . . . . . . . . . . . . . . . . . . . 39

2.5.1 Activation and Feelings of Social Exclusion . . . . . . . . . 39

2.5.2 Activation and Capability for Work . . . . . . . . . . . . . 44

2.6 Conclusion . . . . . . . . . . . . . . . . . . . . . . . . . . . 48

References . . . . . . . . . . . . . . . . . 50

3 Lost Agency? Lived Experiences of Social Assistance Recipients $\begin{array}{ll}\text { in an Activating Welfare State } & 57\end{array}$

3.1 Introduction . . . . . . . . . . . . . . . . . . . . . . 57

3.2 Conceptual Framework: Activation and Agency . . . . . . . . . . . . 59

3.2.1 Activation Typologies . . . . . . . . . . . . . . . 60

3.2.2 Models of Agency in Social Policy . . . . . . . . . . . . . . . 62

3.2.3 Links Between Activation and Agency . . . . . . . . . . . . . 64

3.3 The Dutch Case . . . . . . . . . . . . . . . . . . . . . . . . 65

3.3.1 Responsibility Talk in the Netherlands . . . . . . . . . . . 66

3.3.2 Policy Instruments . . . . . . . . . . . . . . . . . . . 67

3.4 Research Method . . . . . . . . . . . . . . . . . . . . 69

3.5 Findings . . . . . . . . . . . . . . . . . . . 73 
3.6 Discussion . . . . . . . . . . . . . . . . . . . . . . . . 80

3.7 Conclusion . . . . . . . . . . . . . . . . . . . . . . . . 82

References ...................... 85

4 Sustaining the Integrity of the Threatened Self of Social Assistance Recipients: A Clustered Randomised Trial 91

4.1 Introduction . . . . . . . . . . . . . . . . . . . . . . . . . . . 91

4.2 Related Literature . . . . . . . . . . . . . . . . . . . . . . . . . . . . 94

4.3 Context and Intervention . . . . . . . . . . . . . . . . . . . . . . . . . 99

4.4 Research Method . . . . . . . . . . . . . . . . . . . . . . . . 102

4.4 .1 Randomised Clustered Trial . . . . . . . . . . . . . . . . . 102

4.4.2 Sample Size, Randomisation, and Participants . . . . . . . . . 104

4.4 .3 Outcome Measures . . . . . . . . . . . . . . . . . . 106

4.4.4 Analytical Strategy . . . . . . . . . . . . . . . . . . . 108

4.5 Discussion of Results . . . . . . . . . . . . . . . . . . . . . . . . 110

4.6 Conclusion . . . . . . . . . . . . . . . . . . 116

References . . . . . . . . . . . . . . . . . . . . 119

5 Professional Judgements at Work? A Factorial Survey Experiment on Activation Workers' Decision-Making 125

5.1 Introduction . . . . . . . . . . . . . . . . . . . . . 125

5.2 Related Literature . . . . . . . . . . . . . . . . . . . . . . 127

5.3 Conceptual Framework . . . . . . . . . . . . . . . . . . . . . . 130

5.4 Policy Context . . . . . . . . . . . . . . . . . . . . . . . 134

5.5 Research Method . . . . . . . . . . . . . . . . . 135

5.5.1 Factorial Survey Experiment . . . . . . . . . . . . 135

5.5.2 Vignette and Survey Design . . . . . . . . . . . . . 137

5.5.3 Sample Size and Sampling . . . . . . . . . . . . . . . . . . . 140

5.5.4 Analytical Strategy . . . . . . . . . . . . . . . . . . . . . . 142

5.6 Discussion of Results . . . . . . . . . . . . . . . . . . . . . 143

5.7 Conclusion . . . . . . . . . . . . . . . . . . . . . . 159

References . . . . . . . . . . . . . . . . . . 162

6 Conclusion $\quad 167$

References . . . . . . . . . . . . . . . . . . . 174 
Appendices

A Interview Guide . . . . . . . . . . . . . . . . . . 179

B Survey for Citizens in Cluster Randomised Trial . . . . . . . . . . . . 189

C Factorial Survey for Activation Workers . . . . . . . . . . . . . . . 205

D Estimation Results of Factorial Survey Experiment . . . . . . . . . . 217

Samenvatting voor Beleidsmakers

Valorisation Addendum

About the Author

243 


\section{List of Figures}

1.1 Overview of structure, key concepts, and research design . . . . . . . 14

3.1 Aurich's two dimensions of activation . . . . . . . . . . . . . . . 61

4.1 Framework for studying self-affirmation in the context of welfare and activation . . . . . . . . . . . . . . . . . . . . . . . . . . . 9 98

4.2 Average cluster size and minimum detectable effect size $(\alpha=0.05$; two-

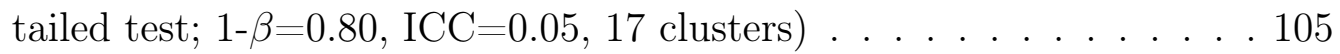

4.3 Adapted Inclusion of Community in Self (ICS) scale . . . . . . . . . . 107

4.4 Histograms and kernel density of outcome variables, by treatment and control group . . . . . . . . . . . . . . . . . . 114

4.5 Comparison of estimation results by different methods and subgroups: Negative feelings of self-worth . . . . . . . . . . . . . . . . . . 114

4.6 Comparison of estimation results by different methods and subgroups: Societal belonging . . . . . . . . . . . . . . . . . . . . 115

4.7 Comparison of estimation results by different methods and subgroups: Job search behaviour self-efficacy . . . . . . . . . . . . . . . . 115

5.1 Components of discretionary reasoning in activation work . . . . . . . 131

5.2 Frames of reference: The relative importance of different work objectives, overall distribution and by team membership . . . . . . . . . 146

5.3 Vignette evaluations (labour market chances) . . . . . . . . . . . . . 148

5.4 Estimation results: Likelihood of finding work within 12 months . . . 150

5.5 Estimation results: Application requirement . . . . . . . . . . . . 151

5.6 Estimation results: Job mediation . . . . . . . . . . . . . . . . . . . . 152

5.7 Estimation results: Personal development . . . . . . . . . . . . . . 153

5.8 Estimation results: Further activities . . . . . . . . . . . . . . . . . 154

5.9 Detailed view: Effects of frames of reference on likelihood of finding work within 12 months . . . . . . . . . . . . . . . . . . . 155

5.10 Detailed view: Effects of frames of reference on application requirement 155

5.11 Detailed view: Effects of frames of reference on job mediation . . . . 155

5.12 Detailed view: Effects of frames of reference on personal development 155

5.13 Detailed view: Effects of frames of reference on further activities . . . 156 


\section{List of Tables}

1.1 Overview of research questions, strategies, concepts, and data . . . 19

2.1 Sample characteristics (in per cent) . . . . . . . . . . . . 37

3.1 Links between Dutch activation policy and agency . . . . . . . . . . . 69

3.2 Sample characteristics (in per cent) . . . . . . . . . . . . . 71

3.3 Links between Dutch activation policy, agency, qualifiers, and mediators 81

4.1 Baseline summary statistics and test of balance for covariates . . . . . 112

4.2 Intracluster correlation coefficients . . . . . . . . . . . . . . . . . . 113

5.1 Overview of hypotheses . . . . . . . . . . . . . . . . 133

5.2 Description of vignette dimensions, levels and wordings . . . . . . . 138

5.3 Survey measure of frames of reference . . . . . . . . . . . . . . . . . . 140

5.4 Activation worker characteristics (in per cent) . . . . . . . . . . 145

5.5 Job characteristics of activation workers (in per cent) . . . . . . . . . 145

5.6 Correlations between different frames of reference . . . . . . . . . . . 146

5.7 Vignette evaluations (demanding and enabling instruments, in per cent) 147

5.8 Variance partition coefficients . . . . . . . . . . . . . . . . 157

D.1 Regression model of assessment of labour market chances . . . . . . . 217

D.2 Regression models of reintegration instruments . . . . . . . . . . . . 220 



\section{Introduction}

\subsection{Background and Motivation}

"What is your conception of the human being?"

This question was raised several times during the sitting of the Dutch Senate on June 24, 2014, when its Members discussed the legislative proposal of the Participation Act (Participatiewet, Pw) (Eerste Kamer der Staten-Generaal, 2014). The aim of this Act, previously passed by the House of Representatives and finally introduced in 2015, was to replace and harmonise a number of laws that were all aimed at providing people of insufficient means with a minimum income, and at promoting their labour force participation.

Opinions on how this could and should be achieved differed, however, and often revealed what Members, and, as a matter of fact, society, more or less explicitly assumed to be the root causes of being out of work. Do people engage in cost-benefit analyses and voluntarily decide to be out of work in light of generous benefits? Do such people therefore need financial incentives to participate in the labour force and to become active as opposed to passive and dependent? Or are reasons for unemployment more intricate and structurally related to a weak labour market? Do those people that experience unemployment deserve support, encouragement, and compassion? Are we dealing with scroungers and free-riders on society or citizens trapped in unlucky circumstances? Are we referring to the bottom of the labour market or the most vulnerable members of the labour force? To what extent is the individual responsible for his or her situation, or can/should be held responsible?

This debate in the Senate reiterated and raised numerous questions that have generated controversy, and have often been discussed in a heated manner, up until today. This thesis was initially motivated by the debates that were led five years ago - not only in the Netherlands, but also, most remarkably, in the United Kingdom (UK); not only in policy circles, yet also among scholars. In light of these debates, the research started out with the following puzzles: What kind of viewpoint informs the 
design of the Participation Act, and what implications does this carry for citizens? Can it ever be just "black or white", or does this zebra thinking hinder a deeper understanding of the causes and consequences of being out of work and adequate policy responses? Do we need to dig more deeply and to allow for variation - in the sense of taking into account the specific decision-making context of citizens, the potentially heterogeneous effects of different policy instruments on citizens' wellbeing and capacity to act, and the lived consequences of the Act when citizens experience it in their interactions with the delivering agencies?

Julien Le Grand, Richard Titmuss Professor of Social Policy at the London School of Economics, highlighted the crucial role of assumptions in social policymaking: "Conscious or not, the assumptions will determine the way that welfare institutions are constructed" (Le Grand, 1997, p. 154). Yet, what if these assumptions are fundamentally flawed, fail to grasp realities as experienced by recipients, carry the risk of reinforcing prejudices and undermining social solidarity? In the worst case, wrong assumptions do not merely lead to inefficient policies, but create "potential longer term, more insidious, "side-effects"" (Brown, 2012, p. 306) that serve to maintain certain interests, while jeopardising others. In line with Brown (2012), the studies assembled in this thesis therefore aim to deconstruct and question underlying assumptions and mindsets ${ }^{1}$ held by policymakers, implementers, and the society at large. The studies do so by focussing on the lived experiences ${ }^{2}$ of individuals who are policy recipients, and by paying close attention to these individuals' relative positions in society and their interactions with policy implementers. Before moving to an outline of the research design and an overview of the chapters, this section aims to locate this thesis in the broader scholarly field and policy context.

The influence that assumptions exert both on a policy's design and its implementation is highly relevant to the field of activation and, specifically, activation directed towards individuals who are able to work and rely on a minimum income

1 A mindset refers to "a person's way of thinking and their opinions" (Cambridge Dictionary), "the established set of attitudes held by someone" (Oxford Dictionary), or a "mental attitude or inclination", a "fixed state of mind" (Merriam-Webster).

2 The use of the term 'lived experience' has been growing in social policy analysis, yet what this notion actually implies has so far appeared more intuitive and received little in-depth discussion, as also noted by McIntosh and Wright (2019). Expressed briefly, in this thesis it is used to emphasise experience that is subjective, situated, and direct. It is personal knowledge that is gained from first-hand involvement rather than being constructed and mediated by other people. Finally, it is used as a "strategy of recognition" (McIntosh and Wright, 2019, p. 456; D. E. Smith, 1987) that is mindful of feelings or interactions that tend to be ignored. 
guarantee. Activation refers to the "policy of designing benefit rules and employment/training services with a view at moving unemployed income benefit recipients into work" (Lødemel \& Moreira, 2014, p. 8). ${ }^{3}$ Minimum income schemes act as financial safety nets for individuals and households that are not eligible for any other form of income protection and whose income falls below a defined social minimum (Lødemel \& Moreira, 2014, p. 8).

Over the past decades, there has been a trend in developed countries from managing risks collectively and sharing responsibilities between the state and the citizen towards the individualisation of risks and responsibilities, and, along with that, the stipulation of behavioural requirements for citizens by the state. In addition to an approach that focuses on the individual and locates the problem at the individual level (in contrast to structural problems in the labour market), Serrano Pascual (2007) characterised the activation paradigm by a focus on wage labour and contractualisation, which defines citizens' obligations in order to receive benefits. Based on the notion of reciprocity, the right to benefits is counterbalanced by recipients' responsibilities and obligations (Paz-Fuchs, 2008). In practice, policymakers reduced the generosity of income support to strengthen work incentives, targeted work-first programmes at wider groups of beneficiaries, introduced increasingly stringent eligibility tests for benefit receipt, or implemented stricter monitoring in combination with inducing or sanctioning certain behaviours (Knotz, 2018; van Berkel, 2010). Moreover, enabling measures, such as training or education, are typically mandatory and non-compliance can be sanctioned (Molander \& Torsvik, 2015). These "people-changing" as opposed to "people-processing" (Hasenfeld, 2010, p. 153) policies imply many assumptions, starting from assumptions about the behaviours that are attributed to the target population and the common values that they share; to assumptions about what causes problematic behaviours; and assumptions on what policies are best suited to achieve desired outcomes.

These assumptions become apparent in discussions on conditionality in social policy. As noted by Clasen and Clegg (2007), an individual's right to receive social benefits has always been conditional one way or the other. For the sake of conceptual clarity, the authors distinguished three forms of conditions. First, benefit receipt is conditioned by belonging to a certain category, for instance having passed retirement age for receiving a pension or being unemployed in order to be eligible for

3 As will be discussed later when the specific policy context in the studied Dutch municipality is introduced, this can entail different forms of work, ranging from regular employment to sheltered employment to activities to spend the day meaningfully. 
unemployment benefits. Second, individual benefit receipt is conditioned by circumstances, for instance by the degree of financial need demonstrated by a means-test. Finally, conditions of conduct impose behavioural requirements and constraints for on-going benefit receipt. It is mainly this conduct conditionality that has featured prominently in discussions and research on activation.

In a historical context, Deacon (1994) identified three linkages that had been put forward in order to justify conditionality. First, deterrence as justification is strongly linked to the US American political scientist Charles Murray. In his book Losing Ground: American Social Policy, 1950-1980, Murray (1984) posited that the expansion of social programmes in the 1960s and 1970s (for example, the Aid to Families with Dependent Children) worsened rather than alleviated the problem of poverty. According to him, these programmes created perverse incentives for people living in poverty that induced dependency and self-destructive behaviours in the long-term. His suggestion was to withdraw all assistance in cash and to leave it to the local level to provide relief schemes, with the possibility to use conditions as communities saw fit. He argued that at this lower administrative level, it would also be possible to distinguish between the deserving and undeserving or, what is often called in today's UK, the strivers and the shirkers (Patrick, 2014). Second, justification in utilitarian terms is represented by the work of Lawrence Mead. He claimed that benefits should be administered in ways that changed attitudes and habits and that thereby reduced dependency. In his words, the trade-off was "whether to stigmatize the least cooperative of the disadvantaged in order to integrate the rest" (Mead, 1986, p. 247). The third justification in paternalistic or moralistic terms claims that conditions are in the best interests of unemployed individuals as these conditions offset the demoralising effects of long-term unemployment.

Sharon Wright summarised these discussions in a stylised way as the dominant model of the "active welfare subject" (2016, p. 235). Critics of this view observe the alleged passivity of benefit recipients and their unapproved behaviours in the context of disempowering narratives of a socially constructed, denigrated "Other" (Lister, 2004, p. 100; Lister, 2015, p. 139). "Othering" (Lister, 2004, p. 99; Lister, 2015, p. 142) denotes the process by which the more powerful 'non-poor' demarcate themselves from the 'poor' and create, maintain, and justify a social distance between 'us' and 'them'. Accompanied by processes of stigmatisation and stereotyping, the individual experience of poverty becomes a shameful, demeaning, and humiliating one that goes beyond the material core of poverty and that is structurally embedded. The way in which (economic) action is affected by social rela- 
tions (cf. Granovetter, 1985) has arguably been less of a concern for policymakers and their "corrective lens" (Patrick, 2017, p. 37) when they have identified problematic behaviours and personal deficiencies, as well as desirable treatments. This has important implications for policy design - both in the sense of the risk of policies to aggravate stigma, shame or existing gaps in society and in the sense of the potential to overcome these problems by taking into account structural barriers, such as the labour market situation.

The effects of societal relations on individual well-being has been examined more closely in recent literature of the psychosocial aspects of poverty. This literature stresses relational $^{4}$ features in the lived experiences of people. It also challenges the strong focus on the effects of activation policies on transition into regular employment and turns attention to the impact on recipients' current well-being (Carter \& Whitworth, 2016; Sage, 2013, 2015a, 2015b; Strandh, 2001). Contrary to the trend of individualisation of responsibilities and "the individualisation of the social" (Ferge, 1997, p. 23), this thesis therefore aims not to lose sight of the societal structures in which policy recipients are embedded, their interactions with significant others, the role played by activation, and what this means for policy design. In this way, it embraces the intrinsic value of relatedness, the ability to appear in public without shame and to be included in the activities that are considered customary in a society (Nussbaum, 2006; Sen, 2000; A. Smith, 1799; Townsend, 1979). ${ }^{5}$

Particularly in the $\mathrm{UK}^{6}$, more recent research has been undertaken that explicitly takes the perspective of how citizens experience living on different types of benefits and how this contrasts with popular narratives told by politicians and the media (Garthwaite, 2016; Patrick, 2017). ${ }^{7}$ This has taken place against a background of "ubiquitous conditionality" (Dwyer \& Wright, 2014, p. 27), that is, an ever expanding and intensifying set of behavioural requirements attached to the receipt of working-age benefits that is backed by a system of sanctions and fines. The

4 By relational, or relational society, I mean that outcomes on the individual level, such as well-being, are the result of both individual capacities and someone's position in society in relation to other individuals (cf. M. L. Smith \& Seward, 2009).

5 The other side of this coin is the experience of stigma, defined by Goffman as "an undesired differentness from what we had anticipated" (1968, p. 15).

$6 \quad$ In the remaining chapters, reference will also be made to other country examples, for example Norway or the United States of America. Given the pertinence of the UK example in academic and policy debates, however, the introduction focusses on this country for clarity of exposition.

7 In a related vein, Geiger (2018) showed that misunderstandings about the benefit system were very common among the British public, in the sense that the level of benefit amounts, public spending, or incidence of fraud were often overestimated. 
large-scale, five-year-long Welfare Conditionality project (2013-2018) in the UK concluded that conditionality was largely ineffective in facilitating individuals' entry in the labour market. It also did not promote the progression of in-work beneficiaries into more secure and better paid jobs (Dwyer, 2018). Instead of enhancing people's motivation, benefit sanctions resulted in a range of negative outcomes in terms of finances, health, behaviour, or in the personal sphere. The results furthermore challenged implicit assumptions about citizens' problematic behaviours, such as the idea of living on benefits as a lifestyle choice. Overall, this project illustrated the disconnect between assumptions and evidence, and the way in which wrong assumptions could lead to ineffective policies and negative repercussions at the societal level.

Whereas English politicians have framed activation policies as part of "empowerment talk" and the "Big Society agenda" (Verhoeven \& Tonkens, 2013, p. 415), Dutch politicians have employed a "responsibility talk" (p. 415). This appeal to citizens' own sense of responsibility has set the tone in the Dutch welfare state throughout the past decades (Peeters \& Drosterij, 2011; Veldheer, Jonker, Van Noije, \& Vrooman, 2012; Verhoeven \& Tonkens, 2013). Particularly since the beginning of the 1990s, the linkages between welfare and work have become stronger and the state's focus has shifted towards the individual (Van Oorschot, 2002). The move from a logic of social protection towards a logic of self-responsibility (Sol, Sichert, van Lieshout, \& Koning, 2008) has formed part of the evolution towards a "new model of responsibility" (Vrooman, Van Noije, \& Veldheer, 2012, p. 19). The state mandates, monitors and sanctions behaviour, yet its realisation is left as far as possible to the citizen. At the same time, public entitlements are reduced. This means, increased individual responsibility, but on terms prescribed by the state (Peeters \& Drosterij, 2011; van Echelt \& Josten, 2012).

In his 2013 King's Speech, at a time after the 2007/08 economic and financial crisis when the Netherlands was still confronted with negative growth rates and increasing rates of unemployment and numbers of social assistance recipients, King Willem-Alexander introduced the term participatory society (participatiesamenleving) that would replace the classic welfare state in the Netherlands (Rijksoverheid, 2013). Everybody who is able to do so is asked to take responsibility for his/her own life and environment. Hindriks (2015), however, critically questioned to what extent unequal opportunities and other inequalities in society were sufficiently taken into account in the rhetoric of the following years. In his view, calls for participation could result in a participation paradox: Insufficient attention to structural factors that impeded participation were too easily disregarded and non-participation at- 
tributed to individual factors such as laziness. As a result, he warned that the call for participation could finally result in stigmatisation and exclusion rather than inclusion.

As in the UK, the role of assumptions, the question as to why somebody does not participate in society, and the extent to which these implicit assumptions are underpinned by evidence, is of central importance. Yet, there are also several differences between the countries, which makes the Netherlands an interesting and relevant case study. In addition to coercive elements, there are a number of other forms of active support available to social assistance recipients that include enabling, human capital enforcing elements. Examples are instruments such as application trainings, specific courses for people aged 45 and above, or internships or participation placements. Most of these reintegration activities, however, are compulsory. Moreover, the 2015 Participation Act introduced a quid pro quo requirement (the so-called tegenprestatie) that allows municipalities to ask social assistance recipients to do something in return for their benefits. These activities are not permitted to jeopardise reintegration in the labour market or crowd-out regular jobs. Non-compliance with the quid pro quo requirement can be sanctioned.

Finally, in the UK, criticism of the current activation approach mainly stems from the academic community. ${ }^{8}$ In the Netherlands, in turn, several municipalities have started to experiment with fewer or different rules attached to social assistance benefits. This takes place against a growing interest in policies that are informed by behavioural sciences ${ }^{9}$ and a move towards a social investment paradigm (Groot, Muffels, \& Verlaat, 2019; Peeters, 2019; Wetenschappelijke Raad voor het Regeringsbeleid, 2014). ${ }^{10}$

8 Moreover, the Scottish Government is currently creating a new social security system and will assume control over a number of benefits from the Department of Work and Pensions. The aim is to do things differently from the UK, a system that is described as stressful and inhumane. Based on the conviction that everybody as a member of society has a right to social security, this new system is dedicated to respecting the dignity of every individual (Patrick \& Simpson, 2019; Scottish Government/Social Security Scotland, 2019).

9 Even though behavioural sciences commonly look at individual behaviour, a major angle is the importance of social norms or contextual cues that shape decision-making. Katherine Curchin (2017; 2019), for instance, used behavioural insights in order to advocate for the provision of stronger social safety nets and discussed the ethical dimensions of attempts to alter behaviour. Another development is taking place in Germany, where the Federal Constitutional Court will have to judge whether sanctions imposed under the unemployment benefits scheme in the Second Book of the Code of Social Law are constitutional. The Gotha Social Court argues that they are unconstitutional as they interfere with the right to a minimum standard of living that ensures a life in dignity, as well as with the right to freedom of occupation (The Federal 
In that sense, a focus on conditionality alone does not do justice to the Dutch approach - nor to the approach in any other country, as it is typically a mix of demanding and enabling instruments that constitute an activation policy. Rather, it becomes necessary to disentangle the effects of different elements of activation and their respective as well as combined effects on individuals' well-being and capacity to act. This more nuanced approach carries the advantage that comparisons between municipalities or countries can be drawn in a more fine-grained way that takes into account the effects of specific activation policy elements and mixes thereof instead of activation policy in general terms. It adds understanding in terms of how and why policy instruments affect recipients, and thereby allows researchers and policymakers to ponder to what extent the results presented here should carry over to other contexts.

In summary, research that has investigated lived experiences of welfare users has challenged implicit assumptions made in policy design and has showcased the missing link between assumptions and the available evidence. This carries the risk that policies fail to meet their objectives or even lead to detrimental outcomes that might not have been considered in the first place, or occur in domains that might have been neglected. Against this backdrop, the initial goals of the thesis were to

(1) examine assumptions about how social assistance recipients make decisions and act in response to activation policy and, based on these insights:

(2) develop and experimentally test innovative policy design solutions that match people's actual psychology, support recipients well-being and agency, and are low-cost, feasible and scalable elsewhere.

In the course of this research, an additional angle was added by taking into account not only citizens, but also activation workers and their decision-making, as well as interactions between citizens and activation workers. In summary, the research contributes to addressing existing research gaps by means of:

(1) an explicit exploration of the links between assumptions and policy design, using a mixed-methods research design and primary data collection;

(2) an analysis of the effects of qualitatively different types of activation instruments, as well as their combined effects;

(3) a focus on outcome variables beyond transition into regular employment, particularly individuals' well-being, including their social relations, and agency;

Constitutional Court, 2018). 
(4) attention to the role of both policy users and implementers, their interactions, and how this shapes outcomes for policy users.

The next section sets out how these questions were approached. This is followed by an introduction to the empirical studies, the key concepts and the links between them.

\subsection{Sequential Exploratory Research Design}

According to Creswell (2009), a research design involves three components. These are the philosophical worldview assumptions that a researcher holds; the strategy of inquiry that she chooses; and the specific methods that she uses to practically implement this approach. This doctoral research is based on a pragmatist worldview that puts the research problem on centre stage. I used sequential mixed methods as a strategy of inquiry, beginning with a qualitative method in order to explore the problem and followed by quantitative methods to test a new instrument and generalise results. For that purpose, I collected qualitative data in semi-structured interviews. Subsequently, I used experimental methods to be able to make causal claims. The aim of this section is to justify the chosen research design and to provide more details on these three interconnected components.

A researcher's "general orientation about the world and the nature of research" (Creswell, 2009, p. 6), her worldview, influences her practice of research. The present thesis is built on a pragmatist ${ }^{11}$ worldview that employs pluralistic approaches to understand a problem. The focus is not on methods, but on the research problem at hand. Pluralistic approaches are conceivable; the criterion is that they have to contribute to understanding the research problem. The key underpinnings are the following (Creswell, 2009):

(1) There is no commitment to one system of philosophy or reality. Pragmatists freely decide on the best suited methods based on their purposes and take into account multiple approaches to collecting and analysing data.

(2) The world is not an absolute unity; likewise, there is no duality between reality of the mind or within the mind. "Truth is what works at the time" (Creswell, 2009, p. 11); The goal is to maximise understanding of the problem.

11 Creswell (2009) distinguished four different worldviews: post-positivism, constructivism, pragmatism, and advocacy/participatory. 
(3) The rationale for mixing needs to be established based on where the researcher wants to go with her research.

(4) Research is context-dependent and situated in society, history, politics, etc.

A pragmatic worldview hence creates the opportunity to embrace multiple methods and different forms of data collection and analysis. A risk is that this worldview is reduced to its practical appeal and that a mere focus on "what works" (Morgan, 2014, p. 1051) neglects the philosophical underpinnings of pragmatism (cf. Denzin, 2012). Yet, a pragmatic worldview goes beyond this practical aspect and urges researchers to reflect on how and why they make choices related to their research, and what the consequences of their actions are. ${ }^{12}$ Against the motivation and initial goals of this thesis outlined in the previous section, I adopted this view, as it allowed me to use tailored methods for investigating my research questions.

First, the apparent gap between popular narratives and rhetoric on the one hand and lived experiences of welfare users on the other hand leads us to question what assumptions should guide policy design. The mismatch urges us to investigate in detail the decision context of social assistance recipients (or the target population more generally) before designing policies. ${ }^{13}$ Qualitative methods that use openended questions are suited to understand the lived experiences of individuals and to let them compile their own narratives, including their own interpretations of what they do and the meaning they give to their activities (cf. Blaikie, 2009). It is possible to explore complex concepts such as an individual's well-being and agency that are shaped by the respondents' relative position in society. Moreover, this approach acknowledges and recognises the unique knowledge and expertise of those who are affected by policies and takes this knowledge seriously (cf. Lister, 2004; Patrick, 2017; Schweiger \& Graf, 2014). The role of the researcher and interviewer was important in the sense that they could influence the creation of information during the interviews and guide respondents towards specific answers. A balance had to be struck between being interested, empathic and concerned while following a neutral approach. Care was also taken to use open, non-leading questions and to follow up and probe responses accordingly. After each interview, the interviewer and I reflected

12 In that sense, an additional dimension is added to the use of the term mindset in the title: "When we are pursuing a research project, we are acting within a mind-set that determines what it means to choose one research topic rather than another as well as what it means to choose one research method rather than another" (Morgan, 2014, p. 1048).

13 The approach is in line with the recent claim to thoroughly explore the specific decision context of (low-income) individuals through qualitative research in order to frame interventions to achieve the intended results (Hall, Galvez, \& Sederbaum, 2014, p. 141). 
together not only about the content of the interview, but also the interview process and behaviours and emotions that had been conveyed. This allowed me to actively and critically reflect on the extent to which a common understanding of the more subtle information provided during the interviews was shared, to scrutinise my own assumptions and to detect my own confirmation biases (see Mason, 2002).

The aim of the second phase of the thesis was to use these insights in order to develop and test an instrument that could contribute to increasing an individual's well-being and agency. The social psychology theory that guided the development of hypotheses was identified and further informed by the key themes and patterns that had been examined in the first phase. In order to establish causality and to attribute changes in an individuals' well-being and agency to the newly developed instrument, I chose an experimental approach. In a randomised controlled trial, individuals are randomly assigned to a treatment group (that is exposed to an intervention or a policy change) and a control group (where there is no intervention or policy change) by means of, put simply, the toss of a coin. The expectation is that in the absence of the tested intervention or policy, the outcomes in the two groups would have been on average the same, given that the groups are large enough. Even though we can never observe the difference between being exposed to an intervention or not on an individual level, we can estimate the average treatment effect, i.e. the difference in the average outcomes between the two groups. More importantly, randomisation allows us to estimate the uncertainty we should associate with this effect and to make statements whether results occurred simply by chance or can be attributed to the treatment (Deaton \& Cartwright, 2018; Duflo, Glennerster, \& Kremer, 2008; Imbens \& Wooldrigde, 2009).

Despite these advantages of experiments, we need to remain cautious. Deaton (2010, 2011) or Barrett and Carter (2010) particularly emphasised the fundamental difference between the use of experiments in natural and social sciences. Since experimental units in the latter case are not merely physical subjects, but human agents, these authors criticised lack of attention to underlying mechanisms that explained why an intervention achieved the observed outcome (or not). Unrevealed behavioural mechanisms become central when thinking about heterogeneity of responses and, closely linked to that, external validity. In that sense, it is an advantage that the design of the instrument was informed by in-depth qualitative research and that the results of the experiments could be linked back to the previously gained detailed understanding of citizens' decision context. 
The final chapter studied activation workers' decision-making and aimed at understanding the principles that guide activation workers' choices. The qualitative part of this research pointed out the importance of caseworkers' decision-making for citizens. Similarly, qualitative studies by other authors have provided rich insights into the context of activation workers' decision-making processes and the factors that are relevant for their choices. Yet, factors that affect workers' decision-making, such as characteristics of citizens, are often highly correlated with each other. As a result, it is difficult or even impossible to separate the influence of one of them from the influence of the other. In an experimental setting, in turn, it would be possible to ensure that different factors are not correlated with each other. However, this usually comes at the price that not many factors can be taken into account and that the complexity inherent in human evaluations tends to be oversimplified.

The solution was to use a factorial survey experiment, a method that implements a multidimensional experimental design within a survey. In a factorial survey experiment, respondents evaluate descriptions of hypothetical persons or situations with various attributes (dimensions), so-called vignettes. The values of these dimensions (levels) are experimentally manipulated across vignettes. The random manipulation of the levels of the dimensions in vignettes, as well as the random distribution of vignette sets to respondents, make it possible to identify clearly the separate influences that guide the evaluations. At the same, more factors can be taken into account than in an experimental setting, so that the factors that influence evaluations are not oversimplified. As in the previous study, the exploratory phase served both as input for designing the factorial survey experiment, but also as a reference for contextualising the results. This again proved the value of combining different methods for collecting and analysing data within a pragmatist worldview that is not exclusively committed to one system of reality.

In addition to mixing methods, this research also spans multiple disciplines, as will become further apparent in the following section that elaborates on key terms and concepts. In line with the pragmatist claim to put the research problem on centre stage, the choice of the strategy of inquiry and the most appropriate method was not confined to a specific discipline, but I ventured into sociology, psychology and economics. In this sense, this research is cross-disciplinary, meaning that it is "substantively based on the analysis and methods of more than one discipline" (Kanbur, 2002, p. 483). In most parts, this research is multidisciplinary and uses different disciplines to answer a common set of analytical and policy questions, rather than aiming for deep integration in an interdisciplinary way at the outset. 
Nonetheless, the conclusion starts working towards a synthesis, with the aim of strengthening the coherence of results that deal with concepts as complex as wellbeing and agency, and increasing the social relevance of the results (cf. Hulme \& Toye, 2006).

\subsection{Key Terms and Thesis Outline}

This thesis consists of four empirical chapters that are linked by a common research agenda and feed into each other. Nonetheless, all chapters can stand alone, meaning that some pieces of information will be repeated in different chapters. While care was taken to structure each chapter in this thesis in a similar way, I also aimed to take into account field-specific language, customs and practices, and the current state of knowledge, as well as to position this research in the respective discipline/s. The aim of this section is to introduce the research questions of the four chapters, define key terms and outline the theories and conceptual approaches that guide them, and highlight the links between the studies. Figure 1.1 illustrates the structure of the thesis, the key concepts that are used, and the research design.

Three key terms are used throughout the thesis. First, as defined above, activation or activation policy refers to the "policy of designing benefit rules and employment/training services with a view at moving unemployed income benefit recipients into work" (Lødemel \& Moreira, 2014, p. 8). This definition distinguishes activation from active labour market policies that can be a subset of activation strategies, but are usually not concerned with eligibility criteria for the receipt of benefits. Activation is also broader than workfare, as additional options such as training, education, or job search assistance are available (Lødemel \& Moreira, 2014, p. 8). In the Dutch context, work can refer to regular or subsidised employment, but also working while retaining benefits, activities in return for benefits, sheltered employment or other ways of spending the day meaningfully. In this research, the focus is on activation of minimum income recipients, in light of the fact that there has been a trend to make the receipt of minimum income benefits conditional on activation requirements throughout Europe and the United States of America. In the Netherlands, these types of benefits are called social assistance benefits and are governed by the Participation Act. Unemployed individuals are eligible to such benefits if they have no employment record, if they were self-employed, or if their eligibility for unemployment benefits has expired. All other unemployed individuals receive unemployment benefits in the framework of the Unemployment Act (Werkloosheidswet, $W W$ ). 


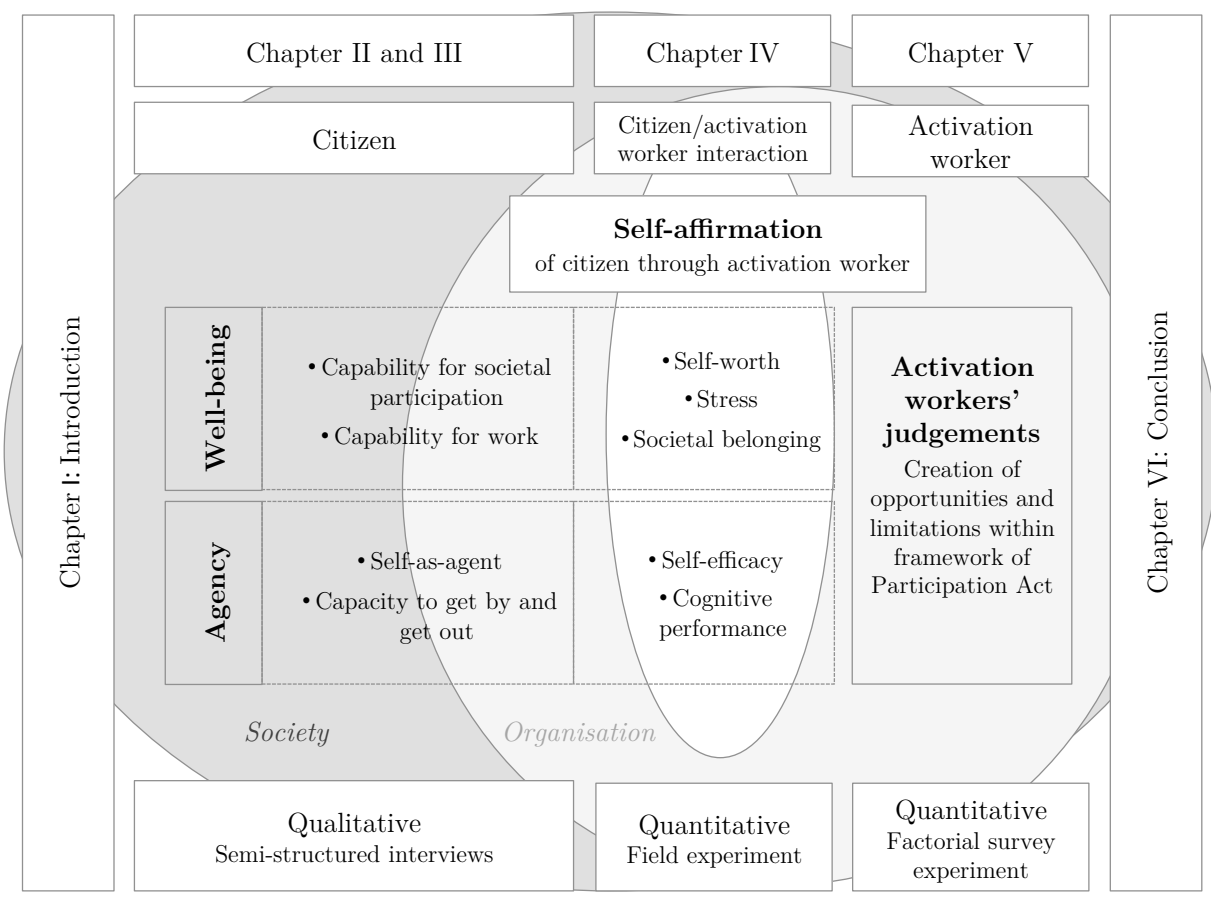

Figure 1.1: Overview of structure, key concepts, and research design

Source: Author's own illustration.

Second, I deliberately employ the term citizen (or, in a descriptive way, social assistance recipient) rather than client in order to focus on the integrity and relatedness of individuals. In this vein, attention is paid to what activation means for citizens' lives and the integrity of individuals in the context of their relationships instead of reducing them to clients. In addition, the term citizen emphasises the idea that people have civil, political, and social rights and stresses their membership of society (Marshall, 1950). ${ }^{14}$ It urges us to think about the ways in which social citizenship has been challenged, reframed or even undermined by the previously described trends from collective to rather individualised responsibility for welfare, and what this means for some of the most vulnerable people and groups in society (Dwyer, 2016; Taylor-Gooby, 2008). Third, I use the more descriptive terms

14 In Marshall's work, social citizenship implies the following: "By the social element I mean the whole range from the right to a modicum of economic welfare and security to the right to share to the full in the social heritage and to live the life of a civilised being according to the standards prevailing in the society" (Marshall, 1950, p. 11). Social citizenship hence relates back to the previous ideas of being able to appear in public without shame and to be able to participate in activities that are considered normal in a society. 
activation worker or caseworker instead of professional in order to highlight the contested question of whether activation work is a profession, as will be discussed in more depth in Chapter 5. Activation workers belong to the larger group of so-called frontline workers (cf. Maynard-Moody \& Musheno, 2000) or street-level bureaucrats (cf. Lipsky, 1980), as they deliver policies at the frontline or the street-level. The defining feature is that they directly interact with citizens and that they can exercise substantial discretion during the execution of their tasks (Lipsky, 1980, p. 3).

Figure 1.1 illustrates that Chapter 2 and Chapter 3 focus on the lived experiences of citizens. Chapter 4 zooms in on the interaction of citizens and activation workers during a meeting. Finally, Chapter 5 investigates the decision-making of activation workers, yet derives its ultimate interest in this topic from the fact that these decisions can have serious implications for the well-being and agency of citizens. The interaction between citizens and activation workers takes place within the organisation, which is indicated by the light grey ellipse. Whereas caseworkers' decision-making takes place within the organisation, an exploration of the lived experiences of citizens cannot disregard the way in which citizens are embedded in society. This is indicated by the darker ellipse.

The guiding concepts of Chapter 2 and 3 are well-being and agency. In order to understand outcomes beyond transition into regular employment, individuals' well-being is approached through the capability approach, originally presented by Amartya Sen in his 1979 Tanner lecture and since then continuously theoretically developed and empirically applied by him and many other scholars (cf. Robeyns, 2017). Rather than focusing predominantly on whether or not somebody transitions into work, the question becomes to what extent citizens have the substantive freedom (capability) to live the kind of life they value while they are receiving social assistance benefits, and the extent to which they can choose the work they want to pursue and have reason to value. Given that social assistance benefits provide for a minimum income only, and also taking into account the current movements and references to increased personal responsibility, the question of the extent to which people in receipt of social assistance feel that they can appear in public without shame is a central one. This will be captured by exploring the capability for social participation, which is further refined by scholarly work on social exclusion. Furthermore, the capability for work is investigated, particularly against the backdrop of increasingly stringent definitions of what kind of work is acceptable. Hence, what are the links between different instruments of activation and recipients' well-being? Under what conditions does activation promote recipients' well-being, or, on the contrary, limit it? In 
Chapter 2, these questions are conceptually discussed and empirically investigated by means of 45 semi-structured interviews with social assistance recipients.

The idea that people should have the freedom to live the kind of life they value entails an element of choice that goes beyond the enhancement of well-being. To take stock of individual choice and responsibility, I refer to the concept of agency. In the capability approach, agency is acknowledged through attention to the process of capability development. For Sen, an agent is "someone who acts and brings about change, and whose achievements can be judged in terms of her own values and objectives, whether or not we assess them in terms of some external criteria as well" (1999, p. 19). ${ }^{15}$ It follows that every individual should be put in a position where she can genuinely exercise agency, and where the social context is organised accordingly. Yet, there is no commitment to a certain account of agency and the concept can be fleshed out in different ways, depending on the purpose (Robeyns, 2017). In Chapter 3, I therefore refer to two models of agency in social policy, namely Lister's (2004; 2015) typology of forms of agency exercised by people living in poverty and Hoggett's (2001) model of agency. Whereas Lister's typology is helpful in order to understand how agency can manifest itself (in the forms of getting by on benefits on a daily basis and getting out in a strategic sense, for instance), Hoggett's model allows for moving on a continuum of empowerment from self-as-object to self-asagent. It is therefore possible to investigate in 45 semi-structured interviews with social assistance recipients the following questions that guide Chapter 3: What are the links between different instruments of activation and recipients' agency? Under what conditions does activation promote recipients' agency, or, on the contrary, limit it?

The empirical results of Chapter 2 and 3 lead to issues regarding threatened feelings of personal integrity and self-worth, feelings of stigma, shame and the psychological threat of stereotyping, the risk of detachment from society through deepened fault lines on the relational and societal level, feelings of limited freedom to act, and the ways in which interactions with caseworkers are central and can be exploited in beneficial ways. Whereas the results in the first two empirical chapters are mainly presented in sociological terms, Chapter 4 makes the step to social psychological theory in order to develop a concrete policy instrument that matches people's actual psychology. Self-affirmation theory, originally presented by Claude Steele in the

15 The use of the expression agent in this sense is different from the way it is typically used in economics, for instance, where an agent often acts on behalf of somebody else (say, a principal) (Sen, 1999). 
1980s (Steele, 1988), is concerned with how people deal with information or experiences that threaten their self-concept, and how the negative consequences thereof can be mitigated.

Self-affirmation is defined as "an act that manifests one's adequacy and thus affirms one's sense of global self-integrity" (Cohen \& Sherman, 2014, p. 337). It has been shown that well-timed affirmations can improve, for example, various well-being and agency-related outcomes in the health and education domain, but also in the context of decision-making of individuals living with a low income. In the concrete case of an application to social assistance recipients in the context of interactions with activation workers at the Social Services office, well-being and agency have to be captured by psychological concepts that can be measured in self-administered surveys. In the well-being dimension, these are self-worth, stress, and social belonging. Agency is approached by looking at a related concept, namely self-efficacy. Previously, Sabina Alkire (2009) suggested investigating self-efficacy measures as a quantitative measure of Amartya Sen's agency concept. Self-efficacy is defined by Ozer and Bandura (1990) as "people's belief in their capabilities to mobilize the motivation, cognitive resources, and courses of action needed to exercise control over given events" (p. 472) and referred to by Bandura (2001) as "the foundation of human agency" (p. 10). Cognitive performance in this dimension is also examined, in the sense of being able to process information as well as possible and take actions thereupon. In summary, Chapter 4 explores the following questions based on a field experiment with 174 social assistance applicants and 15 caseworkers: How can a self-affirmation be integrated in the first meeting between a social assistance applicant with a caseworker? To what extent does the self-affirmation deliver the intended effects?

The last empirical chapter extends the idea that not only the interaction with activation workers can impact on citizens' well-being and agency, but even more so the decisions that activation workers take with regard to a - in their view - appropriate course of action. Different activation workers' judgements create different opportunities or constraints for the same citizen (Eikenaar, de Rijk, \& Meershoek, 2016), including in terms of voice, rights, and redress (Brodkin, 2013). Interview respondents' reports on the fact that activation workers differed sometimes considerably in how they treated them echoes qualitative research that stressed the diversity of contexts within which activation-related decisions are taken, variations in workers' education and job design, preferences and role interpretations and ultimately, different treatment of citizens. The aim of Chapter 5 is a systematic exploration 
of the following question, taking advantage of a factorial survey experiment among 53 activation workers: To what extent do activation workers agree in their decisionmaking and share norms of action? To what extent do disagreements in decisionmaking reflect different role interpretations of activation workers? The final Chapter 6 discusses the overarching results, the contributions to academic literature and the policy implications. To explain the outline of the research design and structure of the thesis, Table 1.1 provides an overview of the research questions, concepts, and data collection as introduced in this section and the previous section.

\subsection{Ethical Considerations}

The research took into account that the majority of participants of the study were vulnerable by virtue of their socio-economic status. For this reason, it was very clearly communicated that participation was completely voluntary, in no way influenced benefit receipt and that the interviews or surveys could be stopped at any time. The interviewer was trained to develop feelings for boundaries and to be respectful and non-ignorant (Flick, 2008). Furthermore, we took into account participants' vulnerabilities by choosing appropriate locations for interviews, such as neighbourhood centres or volunteer workplaces, and by taking into account respondents' wishes regarding day and time of interview as far as possible. During the training of activation workers for the field experiment, care was taken to outline clearly who was eligible for the study, to explain how informed consent should be achieved, to ensure that all relevant information was also delivered verbally, to stress the voluntary nature of participation and to emphasise that non-willingness to participate must be respected.

Informed consent of individuals was formalised with a form, following the templates of the Ethical Committee Psychology (later renamed Ethical Review Committee Psychology and Neuroscience) and the Ethical Review Committee Inner City Faculties. The participants received written feedback including the goal of the study, how the information would be used and a contact person. To ensure confidentiality, the data was anonymised before analysis and stored safely. Only the involved researchers and the respective participant have access to interview data. Data of the field experiment and the factorial survey experiment were anonymised and made available for replication. All studies assembled in this thesis were approved by the Ethical Committee Psychology/Ethical Review Committee Psychology and Neuroscience of Maastricht University. 


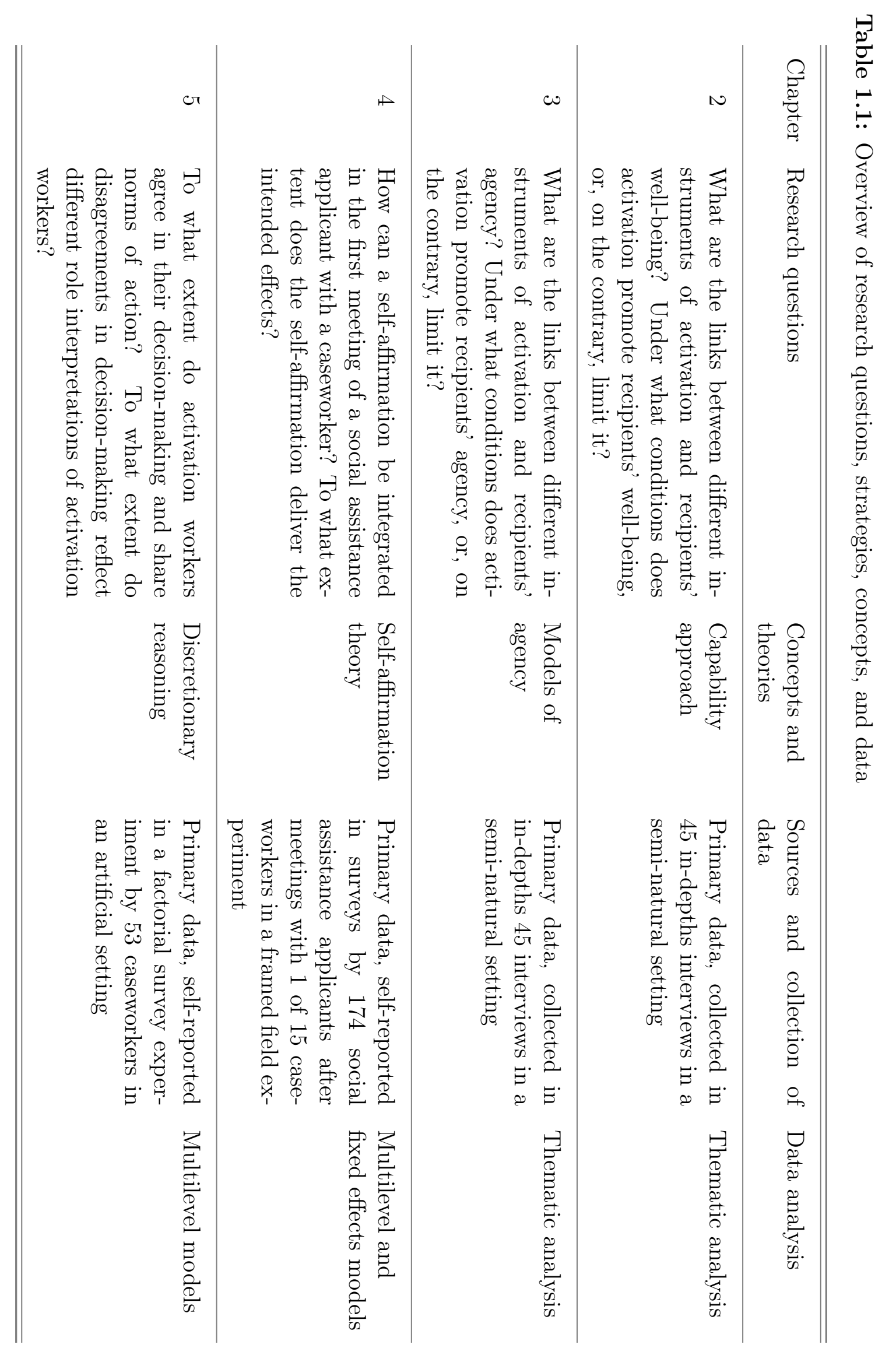




\section{References}

Alkire, S. (2009). Concepts and measures of agency. In K. Basu \& R. Kanbur (Eds.), Arguments for a better world. Essays in honor of Amartya Sen (Vol. 1, p. 455-474). Oxford, United Kingdom: Oxford University Press.

Bandura, A. (2001). Social cognitive theory: An agentic perspective. Annual Review of Psychology, 52, 1-26.

Barrett, C. B., \& Carter, M. R. (2010). The power and pitfalls of experiments in development economics: Some non-random reflections. Applied Economic Perspectives and Policy, 32(4), 515-548.

Blaikie, N. (2009). Designing social research (2nd ed.). Cambridge, United Kingdom: Polity.

Brodkin, E. Z. (2013). Street-level organizations and the welfare state. In E. Z. Brodkin \& G. Marston (Eds.), Work and the welfare state. Street-level organisations and workfare policies (pp. 17-34). Washington, DC: Georgetown University Press.

Brown, P. (2012). A nudge in the right direction? Towards a sociological engagement with libertarian paternalism. Social Policy and Society, 11(3), 305-317.

Carter, E., \& Whitworth, A. (2016). Work activation regimes and well-being of unemployed people: Rhetoric, risk and reality of quasi-marketization in the UK work programme. Social Policy \& Administration, 51 (5), 796-816.

Clasen, J., \& Clegg, D. (2007). Levels and levers of conditionality: Measuring change within welfare states. In J. Clasen \& N. A. Siegel (Eds.), Investigating welfare state change. The 'dependent variable problem' in comparative analysis (pp. 166-197). Cheltenham, United Kingdom: Edward Elgar.

Cohen, G. L., \& Sherman, D. K. (2014). The psychology of change: Self-affirmation and social psychological intervention. Annual Review of Psychology, 65, 333371.

Creswell, J. W. (2009). Research design: Qualitative, quantitative, and mixed methods approaches (Third ed.). London, United Kingdom: SAGE Publications.

Curchin, K. (2017). Using behavioural insights to argue for a stronger social safety net: Beyond libertarian paternalism. Journal of Social Policy, 46 (2), 231-249.

Curchin, K. (2019). The illiberalism of behavioural conditionality: A critique of Australia's 'no jab, no pay' policy. Journal of Social Policy, 48(4), 789-805.

Deacon, A. (1994). Justifying 'workfare': The historical context of the 'workfare' debate. In W. Michael (Ed.), Unemployment and public policy in a changing 
labour market (pp. 53-63). London, United Kingdom: Policy Studies Institute.

Deaton, A. (2010). Instruments, randomization, and learning about development. Journal of Economic Literature, 48(2), 424-455.

Deaton, A. (2011). Understanding the mechanisms of economic development. Journal of Economic Perspectives, 24(3), 3-16.

Deaton, A., \& Cartwright, N. (2018). Understanding and misunderstanding randomized controlled trials. Social Science \& Medicine, 210, 2-21.

Denzin, N. K. (2012). Triangulation 2.0. Journal of Mixed Methods Research, 6(2), $80-88$.

Duflo, E., Glennerster, R., \& Kremer, M. (2008). Using randomization in development economics research: A toolkit. In T. Schultz \& J. Strauss (Eds.), Handbook of development economics (Vol. 4, pp. 3895-3962). Amsterdam, the Netherlands: North Holland.

Dwyer, P. (2016). Citizenship, conduct and conditionality: Sanction and support in the 21st century UK welfare state. Social Policy Review, 28, 41-61.

Dwyer, P. (2018). Welfare conditionality: Sanctions, support and behaviour change. Final findings: Overview. Retrieved July 3, 2018, from http://www . welfareconditionality .ac.uk/wp-content/uploads/2018/ 05/40414_Overview-HR4.pdf

Dwyer, P., \& Wright, S. (2014). Universal credit, ubiquitous conditionality and its implications for social citizenship. Journal of Poverty and Social Justice, 22(1), 27-35.

Eerste Kamer der Staten-Generaal. (2014, June 24). Behandeling Participatiewet en Wet werk en bijstand. Retrieved February 19, 2019, from https://www.eerstekamer.nl/verslagdeel/20140624/ participatiewet_en_wet_werk_en_3

Eikenaar, T., de Rijk, A. E., \& Meershoek, A. (2016). What's in a frame? How professionals assess clients in Dutch work reintegration practice. Social Policy \& Administration, 50(7), 767-786.

Ferge, Z. (1997). The changed welfare paradigm: The individualization of the social. Social Policy \& Administration, 31(1), 20-44.

Flick, U. (2008). Designing qualitative research. London, United Kingdom: SAGE Publications.

Garthwaite, K. (2016). Hunger pains. Life inside foodbank Britain. Bristol, United Kingdom: Policy Press.

Geiger, B. B. (2018). Benefit 'myths'? The accuracy and inaccuracy of public beliefs 
about the benefits system. Social Policy \& Administration, 52(5), 998-1018.

Goffman, E. (1968). Stigma. Notes on the management of spoiled identity. Middlesex, United Kingdom: Penguin Books.

Granovetter, M. (1985). Economic action and social structure: The problem of embeddedness. American Journal of Sociology, 91 (3), 481-510.

Groot, L., Muffels, R., \& Verlaat, T. (2019). Welfare states' social investment strategies and the emergence of Dutch experiments on a minimum income guarantee. Social Policy \& Society, 18(2), 277-287.

Hall, C. C., Galvez, M. M., \& Sederbaum, I. M. (2014). Assumptions about behavior and choice in response to public assistance: A behavioral decision analysis. Policy Insights from the Behavioral and Brain Sciences, 1(1), 137-143.

Hasenfeld, Y. (2010). Organizational responses to social policy: The case of welfare reform. Administration in Social Work, 34(2), 148-167.

Hindriks, F. (2015, October). Gedeelde verantwoordelijkheid in een verdeelde samenleving. Oratie uitgesproken door Prof. dr. F.A. Hindriks bij de aanvaarding van het ambt van hogleraar in de Ethiek, Sociale en Politieke Filosofie.

Hoggett, P. (2001). Agency, rationality and social policy. Journal of Social Policy, $30(1), 37-56$.

Hulme, D., \& Toye, J. (2006). The case for cross-disciplinary social science research on poverty, inequality and well-being. The Journal of Development Studies, 42(7), 1085-1107.

Imbens, G. W., \& Wooldrigde, J. M. (2009). Recent developments in the econometrics of program evaluation. Journal of Economic Literature, 47(1), 5-86.

Kanbur, R. (2002). Economics, social science and development. World Development, $30(3), 477-486$.

Knotz, C. M. (2018). A rising workfare state? Unemployment benefit conditionality in 21 OECD countries, 1980-2012. Journal of International and Comparative Social Policy, 34 (2), 91-108.

Le Grand, J. (1997). Knights, knaves or pawns? Human behaviour and social policy. Journal of Social Policy, 26(2), 149-169.

Lipsky, M. (1980). Street-level bureaucracy: The dilemmas of the individual in public service. New York, NY: Russell Sage Foundation.

Lister, R. (2004). Poverty. Cambridge, United Kingdom: Polity.

Lister, R. (2015). 'To count for nothing': Poverty beyond the statistics. Journal of the British Academy, 3, 139-165.

Lødemel, I., \& Moreira, A. (2014). Introduction. In I. Lødemel \& A. Moreira (Eds.), Activation or workfare? Governance and the neo-liberal convergence (p. 1-18). 
Oxford, United Kingdom: Oxford University Press.

Marshall, T. H. (1950). Citizenship and social class and other essays. Cambridge, United Kingdom: Cambridge University Press.

Mason, J. (2002). Qualitative researching (2nd ed.). London, United Kingdom: SAGE Publications.

Maynard-Moody, S., \& Musheno, M. (2000). State agent or citizen agent: Two narratives of discretion. Journal of Public Administration Research and Theory, $10(2), 329-358$.

McIntosh, I., \& Wright, S. (2019). Exploring what the notion of 'lived experience' offers for social policy analysis. Journal of Social Policy, 48(3), 449-476.

Mead, L. M. (1986). Beyond entitlement. The social obligations of citizenship. New York, NY: The Free Press.

Molander, A., \& Torsvik, G. (2015). Getting people into work: What (if anything) can justify mandatory activation of welfare recipients? Journal of Applied Philosophy, 373-392.

Morgan, D. L. (2014). Pragmatism as a paradigm for social research. Qualitative Inquiry, 20(8), 1045-1053.

Murray, C. A. (1984). Losing ground: American social policy, 1950-1980. New York, NY: BasicBooks.

Nussbaum, M. C. (2006). Frontiers of justice. Cambridge, MA: Harvard University Press.

Ozer, E. M., \& Bandura, A. (1990). Mechanisms governing empowerment effects: A self-efficacy analysis. Journal of Personality and Social Psychology, 58(3), $472-486$.

Patrick, R. (2014). Working on welfare: Findings from a qualitative longitudinal study into the lived experiences of welfare reform in the UK. Journal of Social Policy, 43(4), 705-725.

Patrick, R. (2017). For whose benefit? The everyday realities of welfare reform. Bristol, United Kingdom: Policy Press.

Patrick, R., \& Simpson, M. (2019). Conceptualising dignity in the context of social security: Bottom-up and top-down perspectives. Social Policy $\&$ Administration. doi: 10.1111/spol.12528

Paz-Fuchs, A. (2008). Welfare to work. Oxford, United Kingdom: Oxford University Press.

Peeters, R. (2019). Manufacturing responsibility: The governmentality of behavioural power in social policies. Social Policy \& Society, 18(1), 51-65.

Peeters, R., \& Drosterij, G. (2011). Verantwoordelijke vrijheid: Responsabilisering 
van burgers op voorwaarden van de staat. Beleid en Maatschappij, 38(2), 179-189.

Rijksoverheid. (2013). Troonrede 2013. Koning Willem-Alexander heeft in de Ridderzaal de troonrede uitgesproken. Retrieved September 21, 2017, from https://www.rijksoverheid.nl/documenten/toespraken/2013/09/ $17 /$ troonrede-2013

Robeyns, I. (2017). Wellbeing, freedom and social justice. The capability approach reexamined. Cambridge, United Kingdom: Open Book Publishers. doi: http:// dx.doi.org/10.11647/OBP.0130

Sage, D. (2013). Activation, health and well-being: Neglected dimensions? International Journal of Sociology and Social Policy, 33(1/2), 4-20.

Sage, D. (2015a). Do active labour market policies promote the subjective well-being of the unemployed? Evidence from the UK national well-being pprogramme. Journal of Happiness Studies, 16(5), 1281-1298.

Sage, D. (2015b). Do active labour market policies promote the well-being, health and social capital of the unemployed? Evidence from the UK. Social Indicators Research, 124(2), 319-337.

Schweiger, G., \& Graf, G. (2014). The subjective experience of poverty. sats, 15(2), $148-167$.

Scottish Government/Social Security Scotland. (2019). Our Charter. What you can expect from the Scottish Government and Social Security Scotland. Edinburgh, Scotland: Scottish Government.

Sen, A. (1999). Development as freedom. Oxford, United Kingdom: Oxford University Press.

Sen, A. (2000). Social exclusion: Concept, application, and scrutiny. Social Development Papers, No. 1, Office of Environment and Social Development, Asian Development Bank.

Serrano Pascual, A. (2007). Reshaping welfare states: Activation regimes in Europe. In A. Serrano Pascual \& L. Magnusson (Eds.), Reshaping welfares states and activation regimes in Europe (pp. 11-34). Brussels, Belgium: P.I.E. Peter Lang.

Smith, A. (1799). An inquiry into the nature and causes of the wealth of nations (Vol. 3). London, United Kingdom: A. Strahan, T. Cadell jun. and W. Davies.

Smith, D. E. (1987). The everyday world as problematic: A feminist sociology. Boston, MA: Northeastern University Press.

Smith, M. L., \& Seward, C. (2009). The relational ontology of Amartya Sen's capability approach: Incorporating social and individual causes. Journal of 
Human Development and Capabilities, 10(2), 213-235.

Sol, E., Sichert, M., van Lieshout, H., \& Koning, T. (2008). Activation as a socioeconomic and legal concept: Laboratorium the Netherlands. In W. Eichhorst, O. Kaufmann, \& R. Konle-Seidl (Eds.), Bringing the jobless into work? Experiences with activation schemes in Europe and the US (pp. 161-220). Heidelberg, Germany: Springer.

Steele, C. M. (1988). The psychology of self-affirmation: Sustaining the integrity of the self. Advances in Experimental Social Psychology, 21, 261-302.

Strandh, M. (2001). State intervention and mental well-being among the unemployed. Journal of Social Policy, 30(1), 57-80.

Taylor-Gooby, P. (2008). Reframing social citizenship. Oxford, United Kingdom: Oxford University Press.

The Federal Constitutional Court. (2018, December 10). Oral hearing in the proceedings "Sanctions imposed under the unemployment benefits scheme in the Second Book of the Code of Social Law" on Tuesday, 15 January 2019, at 10:00 a.m. Retrieved January 15, 2019, from https://www. bundesverfassungsgericht .de/SharedDocs/Pressemitteilungen/EN/2018/bvg18-085.html

Townsend, P. (1979). Poverty in the United Kingdom: A survey of household resources and standards of living. Middlesex, United Kingdom: Penguin Books.

van Berkel, R. (2010). The provision of income protection and activation services for the unemployed in 'active' welfare states. An international comparison. Journal of Social Policy, 39(1), 17-34.

van Echelt, P., \& Josten, E. (2012). Werken voor je geld. In V. Veldheer, J.J. Jonker, L. Van Noije, \& C. Vrooman (Eds.), Een beroep op de burger. Minder verzorgingsstaat, meer eigen verantwoordelijkheid? (pp. 95-115). The Hague, the Netherlands: Sociaal en Cultureel Planbureau.

Van Oorschot, W. (2002). Miracle or nightmare? a critical review of Dutch activation policies and their outcomes. Journal of Social Policy, 31(3), 399-420.

Veldheer, V., Jonker, J.-J., Van Noije, L., \& Vrooman, C. (Eds.). (2012). Een beroep op de burger. Minder verzorgingsstaat, meer eigen verantwoordelijkheid? The Hague, the Netherlands: Sociaal en Cultureel Planbureau.

Verhoeven, I., \& Tonkens, E. (2013). Talking active citizenship: Framing welfare state reform in England and the Netherlands. Social Policy and Society, 12(3), $415-426$.

Vrooman, C., Van Noije, L., \& Veldheer, V. (2012). Responsable burgers, regisserende overheid. In V. Veldheer, J.-J. Jonker, L. Van Noije, \& C. Vrooman (Eds.), Een beroep op de burger. Minder verzorgingsstaat, meer eigen verant- 
woordelijkheid? (pp. 11-31). The Hague, the Netherlands: Sociaal en Cultureel Planbureau.

Wetenschappelijke Raad voor het Regeringsbeleid. (2014). Met kennis van gedrag beleid maken. Amsterdam, the Netherlands: Amsterdam University Press.

Wright, S. (2016). Conceptualising the active welfare subject: Welfare reform in discourse, policy and lived experience. Policy 85 Politics, 44(2), 235-252. 


\section{Activation, Societal Participation, and Work: Expansion and Limits of Substantive Freedoms}

\section{$2.1 \quad$ Introduction}

The notion that citizens need to be activated rather than compensated has guided many welfare reforms in advanced economies. ${ }^{1}$ These reforms have frequently entailed a redefinition of the rights and obligations of the state and beneficiaries alike and an increasing shift of responsibilities from the former to the latter. A prominent example of this trend are activation policies that are concerned with the design of benefit rules in combination with the provision of employment or training services in order to move unemployed beneficiaries into work (Lødemel \& Moreira, 2014). The Netherlands are no exception in this regard (Sol, Sichert, van Lieshout, \& Koning, 2008). In 1987, the Netherlands Scientific Council for Government Policy published its report on active labour market policy and introduced the idea that "people who are involuntarily inactive could be required to actively explore the possibilities in the labour market" (Wetenschappelijke Raad voor het Regeringsbeleid, 1987). Today, the currently in force 2015 Participation Act aims at increasing labour market participation of social assistance recipients, including through activity requirements for individual job seekers, job search assistance, work placements, and sanctions in case of non-compliance. Alongside these instruments that are geared towards work, recipients are required to participate socially through activities in return for the receipt of benefits (Government of the Netherlands, 2016).

This chapter investigates the ways in which different instruments of the Dutch activation policy impact on recipients' well-being while living on social assistance.

$1 \quad$ I would like to thank all interview participants and Maastricht Heuvelland Social Services for their cooperation, and the administrative and financial support provided. I also thank visitors of Het Parcours 2016 who assisted in re-translating the original quotes. Comments on earlier versions of this chapter were provided by Franziska Gassmann, Katrin Križ, Ortrun Merkle, Zina Nimeh, Geranda Notten, Keetie Roelen and participants at the APPAM International Conference in London from 13-14 July 2016 and at the HDCA Conference in Tokyo from 1-3 September 2016. 
The relevance of this question is derived from two current academic discussions that are related, but that could each benefit from integrating their theoretical and empirical insights more closely. These are, first, questions on the links between activation and well-being and, second, discussions on the psychosocial effects of living in poverty and implications for policy design. Discussions on the links between activation and recipients' well-being build on the observation that there has been a strong focus on the effects of activation policies on transition into regular employment. Emphasis on this outcome has gone along with a relative neglect of the influence of activation policy instruments themselves on recipients' current well-being (Carter \& Whitworth, 2016; Sage, 2013, 2015; Strandh, 2001). In this respect, Sage (2018) synthesised major theories of unemployment and conceptualised the current experience of unemployment as a process of loss. In addition to income loss, well-being may be reduced because of the loss of the psychosocial benefits of work, such as contributing to a collective purpose in a structured work environment (cf. Jahoda, 1982). Furthermore, unemployment constrains individual autonomy and can lead to loss of agency (Fryer, 1986). Finally, being out of work is associated with loss of social status (Ezzy, 1993). Consequently, we can conceive links between participation in activation activities and current well-being, yet with variations along activation typologies such as 'work-first' or 'human capital development' (Carter \& Whitworth, 2016). Carter and Whitworth (2016) called for advancing knowledge in this area across different contexts. However, an at least equally important point can be made to extend the understanding of recipients' well-being and to further conceptualise and empirically investigate the link between different activation policy instruments and well-being. This is where the second academic discussion becomes important.

Literature on the links between psychosocial effects of living in poverty and/or on welfare benefits and the implications for policy design is inherently concerned with the well-being of policy recipients (Lister, 2015; Pellissery, Lødemel, \& Gubrium, 2014). For instance, the aspect of conditionality and compulsion is perceived critically as it can reduce individual autonomy or heighten feelings of shame. The relational aspects of well-being in light of social assistance receipt have been thoroughly demonstrated in qualitative studies on recipients' experiences of social exclusion and social devaluation, or stigma and shame, in a number of European welfare states (e.g. Chase \& Walker, 2012, 2014; Gubrium \& Lødemel, 2014a; Kampen, Elshout, \& Tonkens, 2013; Marttila, Whitehead, Canvin, \& Burström, 2010; Patrick, 2014; Underlid, 2005). A smaller, but increasing number of studies explicitly looked at experiences with and interpretations of activation policies from the point of view 
of social assistance recipients (Gubrium \& Lødemel, 2014a, 2014b; Kampen, 2014; Kampen et al., 2013; Ohls, 2017). The analyses showed a delicate balance and possible conflict between the potential of policies or programmes to foster a sense of self-respect or to give meaning to participants' existence, while at the same time risking negative emotions, disappointment, or heightened feelings of shame. Here, the design and delivery of dignity-promoting policies can be further strengthened by continued, detailed investigations of the links between different types of activation instruments and well-being of recipients, understood not only as an outcome, but a process (cf. Gubrium \& Lødemel, 2014c; Taylor, 2011).

Against this background, this chapter seeks to answer the following questions: What are the links between different instruments of activation and recipients' wellbeing? Under what conditions does activation promote recipients' well-being, or, on the contrary, limit it? The framework for the analysis is based on Amartya Sen's capability approach that assesses whether "people have the freedoms or valuable opportunities (capabilities) to lead the kind of lives they want to lead, to do what they want to do and be the person they want to be" (Robeyns, 2005, p. 95). The empirical analysis draws on 45 semi-structured in-depth interviews with social assistance recipients in a southern Dutch city. It investigates how a set of activation instruments works together to shape and affect different aspects of well-being, possibly in diametrical directions, and stresses relational features in the lived experiences of individuals. This finally allows identifying in a more nuanced way the well-being enhancing and well-being limiting elements in the Dutch activation policy and places the design and delivery of this policy in a broader context of questions of recognition, dignity, and social solidarity.

\subsection{Conceptual Framework: Activation, Capabilities, and Social Ex- clusion}

The term activation is defined as the "policy of designing benefit rules and employment/training services with a view at moving unemployed income benefit recipients into work" (Lødemel \& Moreira, 2014, p. 8). The common benchmark to assess the impact of activation is recipients' labour market outcomes (cf. Card, Kluve, \& Weber, 2010, 2018). However, this does not capture aspects of individuals' wellbeing while receiving benefits, nor their freedom to achieve well-being in relation to work. It is therefore necessary to define alternative yardsticks to investigate the 
links between activation policy instruments and individuals' well-being. Against the general objectives of activation policy and Dutch activation policy in particular increased labour market participation and societal participation through activities in return for benefits - and the findings of studies on psychosocial aspects of living in poverty, the analysis will be concerned with individuals' freedom to participate in society and to pursue valuable work.

The capability approach is a normative framework that can be used for the assessment of individual levels of achieved well-being or well-being freedom ${ }^{2}$, social arrangements or institutions, or policy design (Robeyns, 2017). The capability approach has previously been suggested as an alternative framework for the assessment of activation policies that goes beyond transition into regular employment (for instance Bartelheimer, Leßmann, \& Matiaske, 2012; Bonvin, 2012; Bonvin \& Farvaque, 2006; Bonvin \& Orton, 2009). It was recently employed by Ohls (2017) or Egdell and Graham (2017) to guide the analysis of recipients' experiences with activation policies. More importantly for the purpose of this empirical capability application, it allows for the integration of social components to the overall assessment of activation policies. It permits the consideration of relational features and an individual's relative position in social structures (cf. Sen, 2000; Smith \& Seward, 2009).

Central to the capability approach is the distinction between outcomes (functionings) and substantive freedoms (capabilities) to achieve these functionings (Robeyns, 2017). Individuals should have the freedoms to lead the kind of life they have reason to value; for instance, to choose the work they want to pursue and have reason to value (Bonvin \& Farvaque, 2006). In that sense, the focus is not only on well-being achievement, but more broadly on well-being freedom. Capability sets reflect the freedom to lead different types of lives. Identical capability sets can thereby result in different outcomes, depending on personal choice that is influenced by an individual's life history and psychology, preference formation mechanisms or social influences on decision-making (Robeyns, 2017, p. 83). From the point of view of the capability approach, resources are merely means to achieve valued functionings.

2 In addition to well-being achievement and well-being freedom, Sen (1985, 1993) referred to two more points of evaluative interest: agency achievement and agency freedom. In contrast to well-being freedom, that is, the "the freedom to achieve something in particular" (Sen, 1985, p. 204) and that is the focus of this study, agency freedom "refers to what the person is free to do and achieve in pursuit of whatever goals or values he or she regards as important" (p. 204). The links between activation policy instruments and agency will be investigated in depth in the following chapter, though not through a specific capability lens, but models of agency in social policy. 
The way in which resources are converted into outcomes differs among individuals and is dependent on conversion factors. This includes personal (physical conditions, knowledge or skills), social (public policies, social norms, or power relations), and environmental (climate, risk of natural disasters, infrastructure) conversion factors as well as distributional rules within families and relational perspectives, such as being relatively poor in a wealthy community (Sen, 1999; as cited in Smith \& Seward, 2009, p. 217).

The question to what extent the capability approach is suited to capture relational aspects is disputed and thus briefly discussed here. Dean (2009) criticised the capability approach for being inherently liberal-individualist and for neglecting a constitutive element of human nature, that is, interdependency. According to him, our relationships do not only promote or limit our capabilities, they also define us. Burchardt and Hick (2016) contended that the acknowledgment of interdependencies does not keep us from assessing individuals' capabilities. The authors refer to work by Ingrid Robeyns (2005) who distinguished between ontological and ethical individualism. For the capability approach, the individual is the unit of moral concern. Yet, this ethical individualism does not imply ontological individualism and could be replaced with the term "the principle of each person as an end" (Robeyns, 2017, p. 59). On a theoretical level, the capability approach does not claim that society is created by individuals acting in isolation, but it takes into account the constraints and opportunities that arise from social structures and institutions. From this perspective, capabilities are a function of capacities at the individual level and a person's relative position in society. What an individual can or cannot achieve also depends on her position relative to others (cf. Smith \& Seward, 2009).

This centrality of social relations and being able to appear in public without shame is explicitly endorsed in Nussbaum's (2006) capability of affiliation, which entails "A. Being able to live with and toward others, to recognise and show concern for other human beings, to engage in various forms of social interaction ... B. Having the social bases of self-respect and non-humiliation; being able to be treated as a dignified being whose worth is equal to others" (p. 77)." A concern with relational issues and processes is also central to the concept of social exclusion (cf. Dean, 2016), that Levitas and colleagues (2007, p. 25) defined in the following way:

"Social exclusion is a complex and multi-dimensional process. It involves the lack or denial of resources, rights, goods and services, and the inability to participate in the normal relationships and activities, available to 
the majority of people in a society, whether in economic, social, cultural or political arenas. It affects both the quality of life of individuals and the equity and cohesion of society as a whole."

With regard to the added value of the concept, Sen, in writing on the idea of social exclusion and its nature, relevance and reach, argued that the approach was useful in "forcefully emphasising - and focussing attention to - the role of relational features in deprivation" (Sen, 2000, p. 8). Social exclusion, that is, "being excluded from social relations" (Sen, 2000, p. 4), could directly represent a capability deprivation as people have good reason to value these relations. In addition to being constitutively part of a deprivation, social exclusion can instrumentally cause further deprivations, for instance when unemployment leads to economic impoverishment that in turn results in homelessness or malnourishment (Sen, 2000). According to Sen (2000), the idea of social exclusion ultimately forced thinking about the extent to which certain forms of exclusion causally led to further deprivations, which is also relevant for policy responses. Vranken (2001) continued to ask the crucial question about reference points of social exclusion, that is, from what someone is actually excluded. Exclusion can occur at different levels of society. "Fault lines" describe a "gap, a wall, or a barrier" (Vranken, 2001, p. 81) that determine whether someone is 'in' or 'out'. In combination with hierarchical relationships between individuals or groups, fault lines indicate processes and situations of social exclusion. Relational fault lines refer to the micro level phenomenon that individuals cannot participate in the exchange of social commodities (e.g. income or status) and are thus excluded from social networks. At a macro level, societal fault lines describe the exclusion from societal structures or processes, such as the division between people with earned income as opposed to welfare income. Recognising the causal link between social exclusion and other deprivations, as well as the distinction between processes of social exclusion at different levels, is important for understanding an individual's position in the social fabric and for designing policies that aim to promote social inclusion and employment.

The capability for work is the second focus point of the assessment. It is "the real freedom to choose the work one has reason to value" (Bonvin \& Farvaque, 2006, p. 6). This implies that there can also be work that one has no reason to value. Besides, the definition of a job that someone has reason to value will differ across individuals, depending on personal preferences or social influences, as well as individuals' specific sets of conversion factors. Drawing on work by the economist Albert O. Hirschman 
(1970), the notion of the capability for work rests on two requirements (cf. Bonvin \& Farvaque, 2006). First, individuals need to have an exit option to refuse work that they deem not valuable. Second, individuals need the option to voice their opinion and make it count, be it in the process that leads to finding work or participating in the definition of the scope and content of the work.

Based on a capability perspective with a focus on relational aspects, activation policies shape and interact with capabilities for work and participation in several ways. First, cash benefits as resources can enhance an individual's relative position and the capability for work if this income support allows the continuation of meaningful participation in exchange relations. Reducing benefits to a level that aims to make refusal of work an unaffordable option, however, can render it impossible for individuals to engage in social networks and lead to social exclusion characterised by a relational fault line (cf. Bonvin \& Farvaque, 2006; Vranken, 2001). Second, skill improvement or training programmes should enhance employability, that is, through promoting personal conversion factors for finding valuable work (cf. Bonvin \& Farvaque, 2006). Yet, equal attention needs to be paid to social conversion factors. Trained skills need to match demand by employers, and (decent) jobs need to be available and accessible in the labour market. Otherwise, human capital improvement will not enhance capability (Bonvin \& Farvaque, 2006; Bonvin \& Orton, 2009). Finally, individual activity requirements and sanctions aim to alter job search behaviour and the likelihood of accepting a job. Implicit assumptions in policy design are either that laziness is addressed by placing constraints on individuals; or that previous discouragements led to a dependency trap that can be overcome by strict requirements (cf. Bonvin \& Farvaque, 2006). This carries the risk of (re-)enforcing prejudices of people in employment against welfare recipients (which would be a societal fault line based on earned income vs. welfare income (Vranken, 2001)), leading to stigma effects or shame and ultimately reinforcing feelings of social exclusion.

\subsection{Policy Context}

There are two principal types of social security benefits for people out of work in the Netherlands: unemployment benefits for individuals with an employment record, and means-tested social assistance benefits for those not eligible for unemployment benefits, or whose entitlements have expired. Since 2008, unemployment rates have been continuously on the rise, increasing from 3.7 per cent in 2008 to 6.9 per cent in 
$2015 .^{3}$ Both the number of unemployment and social assistance recipients has been constantly increasing over this period. Similar to developments in other countries, the logic of activation policies has taken hold in the Netherlands over the last two decades. Since 1996, major adjustments of the legislation related to social assistance have shifted the distribution of responsibility from the national level towards municipalities and the market and increasingly from the state towards beneficiaries (van Berkel, 2007). The Work and Social Assistance Act of 2004 emphasized the principle that people should be reintegrated into the labour market rather than simply being provided with an income, as expressed by the then popular slogan 'work above income'. By changing the financing system and further decentralisation, municipalities were incentivised to reduce the number of social assistance recipients (Blommesteijn, Kruis, \& van Geuns, 2012; van Berkel, 2007).

In 2015, the Participation Act replaced, among others, the Work and Social Assistance Act, with the aim of maximising labour market participation, including of individuals with limited work capacity. Social assistance recipients are obliged to accept and maintain offered work; to sign up at temporary employment agencies upon request by the municipality; to accept work that may require daily travel of up to three hours; to acquire or maintain skills that are needed to find or keep work; to behave and appear appropriately; and to participate in reintegration activities offered by the municipality of residence (Government of the Netherlands, 2016). Furthermore, social assistance recipients ${ }^{4}$ have to engage in activities that are valuable for society in return for their benefits. In case of non-compliance with these requirements, benefit receipt can be stopped for up to three months, whereby municipalities have the discretion to adjust sanctions in line with individual circumstances (Government of the Netherlands, 2016).

We conducted our research in Maastricht. Maastricht has approximately 120,000 inhabitants and is located in the south of the Netherlands. It is a suitable case study as slightly more than half of the social assistance recipients in the Netherlands live in municipalities with more than 100,000 inhabitants. With 47 social assistance recipients per 1,000 inhabitants aged 15 to 65, Maastricht is close to the average of these municipalities. Unemployment rates at the regional level are comparable to the national rate $(6.6$ per cent in the province of Limburg and 7.3 per cent in

3 All figures in this section are retrieved from Statistics Netherlands (Centraal Bureau voor de Statistiek, 2019).

4 Except single parents with children under the age of five or persons who are permanently incapacitated for work. 
Maastricht in 2015). Moreover, Maastricht's age profile resembles the average Dutch profile. The Social Services office of Maastricht is part of a regional collaboration of six municipalities, which jointly devised a policy framework for the implementation of the Participation Act (Maastricht-Heuvelland, 2014). The framework reiterates the central role of individual responsibility and the expectation that everybody works and participates in line with her abilities, preferably through regular employment. After the assessment of work capacity and specific needs, beneficiaries are divided into four categories that reflect their capacity to work on a scale from 0 to 100 per cent and that form the basis for the subsequent placement.

Instruments for placement are directed at either employers or beneficiaries. Employers may receive premiums for recruiting beneficiaries or subsidies for productivity losses due to the employment of individuals with less than 100 per cent work capacity. For recipients, the Act foresees different forms of work in relation to someone's work capacity. This includes regular or subsidised employment, working while retaining benefits, activities in return for benefits, sheltered employment or other ways of spending the day meaningfully. Working while retaining benefits involves instruments such as internships to promote work experience and employee skills or participation placements that aim to contribute to participation, social activation, personal development and increased opportunities on the regular job market. ${ }^{5}$ Activities in return for benefits, such as volunteer activities (though they are compulsory), are not considered reintegration instruments. They may neither jeopardise any reintegration efforts nor substitute regular workplaces. Finally, instruments for development include schooling or personal reintegration budgets.

In line with the conceptual considerations, the different forms of work considered within the Participation Act, particularly participation placements and volunteer activities, could contribute to overcoming both relational fault lines by engaging in activities with other people, and societal fault lines, as people do something in return for their benefits and engage in some type of work. Yet, several aspects could counteract the enhancement of capabilities for participation and work. First, income support might not be sufficiently high to maintain meaningful societal participation, thus leading to relational fault lines. Second, work other than regular employment might not be considered 'real' work either by beneficiaries and/or other people in employment, which, as a consequence, would not reduce the occurrence of societal fault lines. Third, whereas participation placements are explicitly meant to promote

5 Examples of participation placements in our sample included, for instance, administrative tasks in non-for-profit organisations; care tasks in retirement homes, etc. 
personal conversion factors and increase future prospects of achieving regular employment, this is not the case for volunteer activities. Capabilities for participation in society and/or for work might not be expanded if individuals cannot derive value from these activities in terms of societal belonging and/or increased employability. Fourth, increased capabilities for work also depend on the availability of regular employment opportunities as a social conversion factor. Finally, the rule that beneficiaries have to accept jobs that do not directly relate to their qualifications and aspirations could conflict with enhanced capabilities for work.

\section{$2.4 \quad$ Research Method}

The analysis is based on primary data collected in 45 semi-structured in-depth interviews with social assistance recipients in Maastricht between October 2015 and May 2016. The study population included legally competent individuals, 18 years and older, who were receiving social assistance under the Participation Act from the local Social Services office at the time of the interview. Initially, 159 individuals were selected by stratified random sampling (stratified by origin, sex, and age) based on administrative data. Due to privacy laws, the Social Services office sent out the letters that informed recipients about the study. In order to stress our independence as researchers from the Social Services office, and to alleviate concerns of sharing personal details gained during the interviews, the logo of Maastricht University was added to the letterhead. We only contacted recipients who explicitly agreed to participate in the study, either by sending us a response card, or verbally during the follow-up by phone conducted by an employee of the Social Services office. Due to low response rates to the invitation to participate in the study, additional strategies were subsequently employed. These included snowball sampling, contacts via social workers, and contacts via local neighbourhood and Social Services centres.

Table 2.1 summarises the socio-economic characteristics of participants and compares them to the population of social assistance recipients in Maastricht as of July 2015. Participants are slightly older, are more likely to be single, and have higher levels of educational attainment compared to the average recipient of social assistance in Maastricht. Nonetheless, expect for the age group of 18 to 27, we have a diverse sample of participants based on exogenous socio-economic characteristics allowing the exploration of the variety of experiences and perceptions with regard to benefit receipt and activation strategies. 
Table 2.1: Sample characteristics (in per cent)

\begin{tabular}{lrr}
\hline \hline & Sample & $\begin{array}{r}\text { Population of social } \\
\text { assistance recipients in } \\
\text { Maastricht }\end{array}$ \\
\hline Age (in years) & & \\
18-27 & 2.2 & 7.5 \\
$28-44$ & 26.7 & 35.1 \\
$45+$ & 71.1 & 57.4 \\
Male & 42.2 & 43.9 \\
Dutch & 86.7 & 85.5 \\
Foreign background & 12.0 & n.a. \\
Education & & 4.9 \\
No primary education & 0.0 & 30.8 \\
Primary education & 8.9 & 46.9 \\
Secondary education & 68.9 & 7.7 \\
Tertiary education & 22.2 & 9.9 \\
Unknown & 0.0 & \\
Civil status & & 44.9 \\
Never married & 53.3 & 22.0 \\
Married & 11.1 & 1.5 \\
Widowed & 4.4 & 31.7 \\
Divorced & 31.1 & 59.5 \\
Household composition & & 23.9 \\
One-person household & 64.4 & \\
Single-parent household & 15.6 & \\
Couple & 20.0 & \\
\hline \hline
\end{tabular}

Source: Administrative data provided by Social Services Maastricht Heuvelland.

Notes: Figures for the population of social assistance recipients in Maastricht refer to July 2015.

Data was collected in semi-structured interviews to achieve a detailed, contextualised understanding of lived experiences regarding social assistance receipt and activation and beneficiaries' own interpretations of what they do and why they do it, what they value and why, and perceptions of what hinders or supports them. The interviews used open-ended questions and appropriate probing questions to let respondents compile their own narratives around a series of key topics: experiences with living on social assistance, including feelings of belonging to society; the meaning of work; the current job search process; experiences with activation activities; and dreams for the future. Moreover, we gathered background data on demographic 
profiles using a simple questionnaire at the end of the interview. The interviews took place in neighbourhood centres or at individuals' participation placements and lasted typically between 35 and 60 minutes. All interviews except for one (during which notes were taken) were recorded and transcribed verbatim. Interviews were anonymized before continuing with data analysis. Transcription and data analysis were performed with the qualitative data software NVivo. Interviews were conducted and analysed in Dutch and only quotations that are included in the chapter were translated into English. Ethical approval was obtained prior to the interviews from Maastricht University and ethical considerations were respected throughout the study. All names that are used in this chapter are pseudonyms.

The transcripts were analysed using a thematic analysis, which is a widely used method to identify, analyse and report patterns in data (cf. Braun \& Clarke, 2006). For this analysis, the aim was not to provide a rich description of the entire dataset, but a more nuanced account of a group of themes. The focus on specific themes was guided by the research questions and conceptual framework outlined above. In that sense, themes were mainly identified based on the analytical interest (theoretical thematic analysis). The analysis considered latent themes that went beyond what a respondent had said, but also aimed to identify underlying concepts.

Data analysis followed the process suggested by Braun and Clarke (2006). Being present at the interviews, transcribing data and re-reading it actively all provided familiarity with the data. The initial codes were based on the conceptual framework outlined above. For instance, we first looked at capabilities for societal participation - the real freedom to participate in society in a way that the individual has reason to value - with reference to the concepts of relational and societal fault lines. In the course of data analysis when searching for additional themes, individuals' own definition of societal belonging were added as code. In the next step, the theme of societal participation was maintained and refined to have three sub-themes: relational fault lines, societal fault lines, and individuals' own definition of societal belonging. Related to capabilities for work, characteristics of work that individuals have reason to value were looked at. During the familiarisation with the entire data set, we soon decided to refer to the latent functions of work described by Jahoda (1982) as codes. In an iterative process, two additional codes were added to capture preferences and skills, as well as aspects related to personal development. Finally, the main theme of capabilities for work was maintained.

In terms of factors that expanded or limited the capability for societal participa- 
tion and work, codes referred to the different elements of activation policy (namely different types of placement instruments, income replacement, code of conduct and sanctions, caseworkers), as well as perceptions of the labour market situation, employers' discrimination based on age, and the perceived views of others, such as family and friends or people in employment. Starting at the stage of initial coding and throughout the refinement of the codes, we thought about the relationship between codes related to well-being, to activation policy instruments, and to social conversion factors. In addition to searching for themes and patterns across respondents, respondents' respective accounts were repeatedly read en bloc while the thematic analysis was being conducted. In this way, the integrity of individual accounts was preserved and (dis)continuities or contradictions within individual stories could be detected and put in context. This also helped in identifying not only the underlying meaning of each individual theme, but to consider how it linked back to the overall research questions and the conceptual framework.

\section{$2.5 \quad$ Findings}

The onset of a period of social assistance receipt was typically connected to one or sometimes several far-reaching life events that entailed some sort of loss - loss of job or enterprise, of partner or good health, or of home country in the case of refugees. These losses and the need for social assistance led to profound changes in their daily lives, which were often experienced as a reduction of personal opportunities, autonomy and freedom or intrusion in someone's private life. Respondents used words such as 'painful', 'constrained', 'limited', 'not free', 'dependent', or 'having no choice', or described reduced margins of opportunities, as Sara $(45+)$ put it: "You can cope with social assistance benefits for a certain period. You also learn to live with it. But there comes a point when you also notice that it is no longer possible to fulfil your wishes."

\subsubsection{Activation and Feelings of Social Exclusion}

We consider three ways in which experiences of social exclusion manifest and how these relate to income support and activation. We start with perceptions of relational and societal fault lines respectively to uncover different levels of feeling excluded. Respondents' own definitions of belonging to society are subsequently reviewed to explore what individuals themselves value. As will be discussed, two 
types of benchmarks emerged in this respect.

During the interviews we asked about perceptions of the current financial and social situation. The level of social assistance is tied to the national minimum wage; however, the amount an individual receives depends on existing income, household composition and the age of the recipient. Nearly all respondents reported that the benefits were sufficient to provide for all basic necessities such as rent or food (a "survival kit", as Martin, 45+, called it), yet did not cover any extras or unexpected expenses, let alone savings. "There's actually nothing fun about living on social assistance benefits", Maria $(45+)$ said. The extent to which individuals managed to cope with benefits was often related to the financial space people had in the past. Some recounted experiences of limited means during childhood that helped them learn to cope with little resources. Others referred to their resourcefulness or creativity in making ends meet, the fact that they managed their resources economically, or the need to make conscious choices.

Some respondents immediately raised the consequences of constrained financial resources on their social interactions and thereby described instances of relational fault lines. Participants named a range of social activities that they could no longer engage in, such as going to the cinema or theatre, inviting friends or eating out, going on vacation, taking part in a class at an art academy, or even a newspaper subscription. These experiences were described as 'limiting' and as situating the respondents 'outside society'. Anne $(45+)$, for instance, had lived on social assistance for many years due to her health condition. After previously having led an active and involved life including work, her family, and volunteer activities, she had to realise that the return to regular employment had become out of reach. Anne described a gradual process of social isolation after years during which she had not been able to participate in social activities: "You just notice that being on social assistance actually makes you fall more and more out of society." In some instances, friends offered to finance social activities, but this was not what respondents wished for: "... which also does not make you feel good when you have to depend on others", as Rita (45+) described this "emotional toll" (Gubrium \& Lødemel, 2014b, p. 196). In another case, the respondent's concern was less about herself, but about the extent to which her child could take part in activities and compare herself to other children, such as going to the city with friends and having the sneakers that everybody had.

The experience of deprivation is therefore not an absolute one in the sense that 
individuals can no longer afford basic needs, yet a relative one, meaning that certain costs of social inclusion are not covered by income support. This is different from Jahoda, Lazarsfeld, and Zeisel's (1971) study where unemployed individuals received basically no public support and struggled to meet basic necessities. However, based on a review of studies in the following decades when welfare benefits were widely available, Jahoda (1982) maintained her conclusions on the psychological strain of job loss. The individual stories about the onset of the social assistance spell and experiences further showed that living on social assistance was far from being a conscious lifestyle choice, a policy narrative strongly conveyed for instance in the United Kingdom, though lived experiences of English welfare recipients differ strongly (Patrick, 2014).

However, feeling excluded from social networks is not necessarily a consequence of living on social assistance. While many respondents experienced no changes in their social networks, were quite happy about their social situation or did not perceive a negative association with social assistance receipt, some even reported enlarged networks. Having more time to engage with others or participating in volunteer or participation activities contributed to feelings of being involved. However, the latter effect can quickly erode once these activities come to an end, as the case of Thomas $(45+)$ illustrates. He applied for social assistance in 2010. In 2011, he started with a participation track that matched his interests and due to his active involvement, his social network widened considerably. After the end of this track in 2013, however, his world became smaller again as the network quickly eroded.

Several respondents, both previously in salaried employment and self-employed, associated eroding networks with more difficulties to reintegrate into the labour market. In the case of Collin $(45+)$, remarks by others, such as caseworkers or other recipients, on the importance of networking for finding a job fuelled his frustration in light of his perception of his personal situation. He reiterated during the interview: "Once again, because your network, your social network, which you actually need to find work, erodes. You are no longer part of the network where people work, thus ..." The narratives of self-employed respondents revealed that in addition to limited financial resources that render it problematic to start a new business, rapidly experienced exclusion from professional networks further limited their entrepreneurial ambitions. Complementing Migheli's (2011) notion that embeddedness in interpersonal networks promoted the attainment of new capabilities (e.g. the capability for work) in a dynamic process, these participants described a downward spiral in which losses of exchange relations reduced capabilities for work. 
The distinction that is made and experienced between those with and without work leads to notions of social exclusion from productive processes, that is, societal fault lines based on employment status. This idea emerged in our interviews in two ways. First, individuals referred to the fact that being out of the labour force was synonymous with not being part of society. Ellie (28-44) said: "Currently I don't feel ... a sense of belonging. Yes. [Long pause] I don't work." Feelings of not being free, not being accepted, being less valued and particularly of being dependent were conveyed in these stories. For example, Stephen (28-44) said:

"Yes, well, that's because I still depend on society and am not serving it. Yes, and that's what I find quite a problem. So for my feeling, yes, I think that things will get better again only once I am out of social assistance."

Second, the role of work as a marker of difference and division in society emerged when respondents referred to participation placements (which approximately half of our respondents had) or volunteer work as letting them derive a feeling of societal belonging, usefulness and contribution to a collective purpose. Greta, 45+, had felt part of society when she worked, but she also felt it as a volunteer and considered these as two different ways of creating a notion of societal belonging. When asked about the way in which she currently felt part of society, Lilly (18-27) explained with reference to her participation placement: "I work here. I mean, I am here for the elderly." However, some respondents qualified the relationship between volunteering or participation activities and societal belonging in important ways. They illustrated subtle dimensions when contrasting their own activities in relation to others, specifically to those in paid employment working in the same organisation. Linda $(45+)$ was confident about her role in society and considered herself as the 'mother' of the place where she volunteered. Nonetheless, she felt that less value was attached to her work than to the work of the paid and mostly highly educated employees:

"People ask: 'What sort of work do you do?' And I say: 'Well, I do [name of volunteer activity].' Because I do that while retaining benefits, so I am actually paid for it. And then they say: 'Oh, wow, yes, you do that? Ho. Or do you do that as a volunteer?' 'Yes, I do that as volunteer.' 'Oh, okay, then ...' ... Then you are just taken less seriously."

Comparable feelings emerged among respondents regarding the fact that their 
work was not paid, or, more specifically, that they did the same work as employees, but were not paid and hence not valued equally. The most striking example was that of Greta, who was, within the social assistance scheme, considered for a temporary replacement of an employee on maternity leave. She felt that people were forced to do regular work for which others earned a decent salary under the disguise of an activation policy, but without the real opportunity to reject this work under the threat of sanctions. Matthew $(45+)$ threw into sharp relief this perspective: "I almost call this modern slavery."

Several respondents mentioned feelings of stigma or shame. Caroline $(45+)$ was confronted with her adult son, who found it terrible that she lived on social assistance, saying: "Get a job." Others told about current or past feelings of shame or negative feelings about having to depend on the state, either because they felt that they were young, healthy and willing to work, or because they had been working for their whole lives and suddenly had to adjust their mindsets. Finally, some respondents had been confronted with other people's views on social assistance recipients as free-riders or spongers who were lazy and chose not to work. This adds, in the words of Nancy Fraser, "the insult of misrecognition to the injury of deprivation" (Fraser \& Honneth, 2003, p. 65). Respondents found different ways of coping with negative attitudes. They pretended that they received a different type of benefit that felt more socially acceptable, such as sickness benefits, avoided situations in which they had to reveal their 'status' as social assistance recipients, or evaded social contacts completely. Finally, several respondents referred in this respect to other recipients that might well behave in the way that these prejudices suggested and distanced themselves from these 'others'. Chase and Walker (2012) described how adults living in poverty in the United Kingdom used this strategy of 'projected shaming' to cope with shame imposed on themselves. However, this undermined social solidarity among people who all had to deal with experiences of hardship and risked the "atomisation of modern society" (Chase \& Walker, 2012, p. 739).

The quotes in this section have shown that respondents differed in their feelings of belonging to society. Importantly, the ways in which they personally defined whether they belonged to society or not varied. Two types of benchmarks emerged from the narratives. First and in line with the notion of a societal fault line, individuals described the distinction between working and not working. Volunteer work or participation placements have the potential of taking the role of paid work, yet with the subtle differences outlined above. Second, feelings of societal belonging were equated with a sense of concern about society, being interested in political and 
societal issues, and with being a relevant and involved part of society. Volunteering or participation placements have the potential to establish feelings of societal belongings, as illustrated by the quote from Greta:

"I can imagine that if I would not have [the volunteer activity], that I would feel very lost. Then I can ... imagine very well that you have the feeling of steadily drifting apart from what happens around you. But just because I . . . am involved in different things, I feel indeed that I belong to society."

Or Sara:

"Being part of society means for me to contribute something and to be in contact with people. ... The identity, what I have in terms of experience and knowledge and weight, and in terms of my character, that I can contribute. And that is very ... nice."

Hence, volunteer or participation activities can enable beneficiaries to engage in networks, maintain social contacts and contribute to a collective purpose, thus in a sense widen "their sphere of existence" (Jahoda et al., 1971, p. 77). Nonetheless, these activities cannot completely bridge the fault lines that emerge, which will be further investigated when considering capabilities for work.

\subsubsection{Activation and Capability for Work}

Our interviews revealed at different points the type of work people valued and why, particularly when asking about the ways in which having work would make a difference to the current situation, the meaning of work, what type of work they looked for and what kind of reasons they could imagine to decline a job offer. After looking at perceptions of the type of work people have reason to value, we explore to what extent activation policies contribute to individuals' capability to find and pursue work that they value.

"Yes, more freedom. Simply to be financially independent, that's what matters most. And I have become really convinced, but that's something 
I've known for a while already, that work is something you simply must enjoy." (Jane, 45+)

This quote by Jane exemplifies that the meaning of work extends beyond its manifest function of providing the means of subsistence (cf. Jahoda, 1982). For her, work corresponds to having more freedoms by being financially independent and not having to comply with any obligations. Throughout her career path, she had strived to find work that she had reason to value, which even led her to quit her job to set up her own company. Similarly, Wilma $(45+)$ described that during the 40 years that she had been employed, she had consistently followed the credo to apply for a new job as soon as she no longer enjoyed her work.

A basic characterization that described the attitude of many respondents towards work was that it had to be nice or pleasant ${ }^{6}$, which comprised aspects beyond financial motives (cf. Jahoda, 1982). First, respondents valued work because of the social contacts - meeting new people, receiving fresh stimulus, working in a team with friendly colleagues who are on the same page, exchanging thoughts, and enlarging personal network. Second, many respondents emphasised some sort of collective purpose they sought, such as helping or being of significance for others, and making a societal contribution. Furthermore, interviewees reported on the importance of being active and structuring their day, getting satisfaction and meaning from work and being valued for it. Roshan $(45+)$ explained: "Yes, work means everything to me ... I can't live without ... I can't sit still ... Your life becomes steady ... Your character becomes very good." For Peter $(45+)$, work created a social context which included the fact of being visible and noticed.

In addition to these latent functions of work that were also reported in studies by Kampen (2014) or Underlid (2012), respondents emphasised two more aspects that contributed to the value of work. First, work has to be appropriate regarding previous work experience and education, individuals' interests and preferences, physical or psychological health conditions, or caring responsibilities. For some respondents, the circumstances of their benefit application necessitated a (re-)orientation. This could be related to health issues that rendered it impossible to engage in previous work activities, or it could stem from very limited work experience. Second, people are looking for challenges and want to keep on learning and developing themselves. This encompasses a strong forward-looking element regarding the perspectives that peo-

6 The Dutch word 'leuk', which was used by respondents in this context, has no direct equivalent in English. 
ple want to have. For Stephen, creating future opportunities for pursuing valuable work through investing in his education today conflicted with his present endeavour for independence:

"And then I'm afraid that I will get stuck, yes, being forced to work to pay the fixed costs without being able to move forward. So I try to follow a training course or something from the situation I'm in. So in that sense, I try to use the possibilities that are available. Maybe this doesn't go well together with the fact that I don't like being dependent, but that's the only possibility I have. Otherwise, yes, I get stuck in having to work to be able to stand on my own feet without me being able to move ahead."

The question is to what extent activation policies contribute to the enhancement of real freedoms to pursue valuable work. We look at three aspects: the value that individuals derive from volunteering or participation activities; conflicts that emerge between volunteering/participation placements and regular work; and the role of caseworkers.

Many aspects that people valued in work beyond financial motives - being active and in contact with others, contributing to a societal purpose, having a meaning for and being valued by other people - were experienced in the context of volunteer or participation activities. Yet, this was only true under the condition that the activity matched the individual's interests and experience, enabled the application of existing skills or contributed to the development of new skills or work experience, and/or opened up perspectives for paid employment - which is explicitly the goal of participation placements, yet not of activities in return for benefits. Many respondents were satisfied with their volunteer activities and participation placements, except for the fact that they were not paid. They had often chosen these activities by themselves or had been energetically shaping them. Others had had unpleasant experiences with volunteer work and had actively sought out new workplaces to find something from which they could derive value. However, our interviews also confirmed previous findings by Kampen (2014) that volunteer activities (rather than participation placements) can conflict with transitions into regular employment. This is how Sara described her perception of the conflict between personal and societal objectives: "It is an important contribution, but it is unpaid work. And as time goes by, it limits the possibilities that I want to have." Collin felt frustrated by investing considerable time in an activity that he experienced as an impasse rather than a path towards work: 
"The intention is that the track leads towards paid employment. But that simply ... doesn't happen. Thus, you don't get paid employment. It leads to nothing. You spend hours there, and you hope and hope, but it doesn't happen."

While volunteering or participation activities can potentially contribute to developing personal conversion factors, the lack of employment that fits a person's capacities equally compromises the capability for work. Nearly all respondents older than 44 years perceived their age as a major reintegration constraint, a situation further exacerbated by the perception of limited availability of jobs within their area of expertise. This constraint applied to highly educated individuals, but was also felt by lower-skilled workers. The latter could either no longer work in their often physically demanding professions due to health issues or faced structural changes in the labour market away from manufacturing towards the service industry.

Finally, the role of caseworkers becomes apparent in the context of enlarging opportunity sets. To enhance the capability for work, caseworkers would have to consider both individual capacities and an individual's social context. Relationships with caseworkers that were experienced as positive did exactly that: Respondents described them as sitting opposite a caseworker who explored their personal situation, circumstances and constraints and perceived the recipient as an individual with a unique past, present, and future. The caseworker recognised their willingness or motivation and discussed and opened up perspectives together with the recipient. Beneficiaries valued discussions on an equal footing and the transparency, availability, and support or advice provided by the caseworker if needed. Hence, we see a relational component in the sense of understanding an individual's context including different arenas such as family, friends, other (employed) people and the labour market; a dynamic component pertaining to an individual's life story including future prospects; and an agency component referring to making your voice heard in the process of participating in society and finding work. In contrast, negative caseworker-recipient interactions were described as hierarchical relationships in which beneficiaries felt belittled, judged, not taken seriously or held responsible for their situation without consideration of the operating constraints. Peter explained his vision of a valuable relationship:

"... [a caseworker] who does not talk to you from a position of hierarchy, saying: 'Let me tell you what you may and may not and must do. And if 
you don't do that, I'll punish you.' But who says: 'We are equal. Now, what about your story?"”

\subsection{Conclusion}

The capability approach as an alternative framework to investigate the design of activation policies introduces a mindset that explicitly considers an individual's relative position in social structures and what this means in terms of having the freedom to live the life one values. The normative benchmark for the assessment of activation policy instruments was the idea of enhancing capabilities for participation in society and work. This chapter investigated the often ambiguous ways in which qualitatively different types of activation instruments expand or limit these capabilities. This included benefit amounts and the extent to which they allow meaningful participation in exchange networks; societal gaps that emerge from being 'in' and 'out' of employment; or considerations of the enhancement of personal skills in combination with individual activity requirements in the context of regional labour markets. This is important as these insights on the impact of a policy's design and delivery on relational aspects of individual well-being can be used to reflect on a society's commitment to dignity.

Throughout the interviews, individuals' assessments of their personal situation were based on two types of comparisons in time and in space. In space, they were gleaned from the positioning of one's situation in terms of finances and social relationships in relation to others, such as family and friends or people in employment. Equally important was a temporal comparison of one's present situation to one's own past. This was complemented by looking forward and imagining and opening up valuable future opportunities, which emphasises the hopes and aspirations that respondents have for themselves. Caseworkers who are able to understand and through their interactions with recipients respond to the dynamics of an individual's life course and perceptions around relativity in society can contribute to recipients' well-being while living on social assistance.

In light of these constant comparisons, the question of 'exclusion from what?' proved to be a useful device to understand the impact of different elements of activation policies on current well-being in a more nuanced way. "Relational wounds" (Frost \& Hoggett, 2008, p. 440) are inflicted in different ways - exclusion from meaningful personal relations, or exclusion from productive processes - and in that way, 
attack a person's self-respect from various angles. In the worst case, behavioural requirements and sanctions that are implicitly loaded with assumptions on recipients' (lack of) motivation and (irresponsible) choices, in conjunction with limited financial means, accumulate and constitute a constant threat to the self. Defending one's integrity can then require considerable emotional labour, involving strategies of coping with stigma and shame that themselves can be detrimental to one's societal participation. Beyond these wounds on the individual level, the described instances of downward social comparisons and 'projected shaming' on other social assistance recipients carry the same risk of eroding social solidarity as has been described in the context of the United Kingdom (Chase \& Walker, 2012). The relative position in society was also important in terms of capabilities for work. Respondents often had a very good understanding of the instrumental and intrinsic importance of capabilities and were aware of the interplay of personal and social conversion factors. For instance, individuals commented on the experience of professional networks that dried up and not only limited capabilities for societal participation in the present, but also for work in the future. Or, individuals reflected on their age in relation to perceived age discrimination by employers or their skills in face of structural changes of regional labour markets.

The discussions on what type of work individuals have reason to value leads to broader considerations of what type of work society values, which manifests itself in the Participation Act and its implementation, but also in interactions of social assistance recipients with people in regular employment. The findings show that respondents appreciated the latent functions of work, namely social contacts, activity, structure, collective purpose, and status (Jahoda, 1982). This was complemented by valuing work that related to their own interests and experiences acquired in the past and an endeavour to continue learning and developing. On the upside, all these latent functions of work could possibly and were often satisfied through volunteer work or participation placements, so that these instruments can indeed have a positive impact on individual well-being while living on social assistance.

The crucial point that is needed to bridge societal gaps, however, is to what extent work other than regular employment is recognised by others in a society such as the Dutch where status has to be 'earned' (Elshout, 2016; Kampen et al., 2013; Sage, 2019). The current design of the Participation Act has arguably neglected the broader societal implications that it carries, namely that a group of individuals is put at risk of deeper exclusion as non-participation could be equated with nonwillingness to contribute to society. In that sense, the frequently named financial 
motives do not only relate to financial independence. Rather, monetary remuneration indicates to what extent an activity is deemed productive or 'worthy' from a societal point of view. The philosopher Axel Honneth, for instance, proposed a definition of work that included every activity that is required for the reproduction of society (see Schweiger, 2013, p. 544). This entails activities such as giving birth or caring for children and the elderly, and arguably one could equally include volunteer activities that bear societal relevance, or continued training and education.

Closely related, we need to ask what type of work is considered acceptable. At present, this is defined very broadly. The definition of acceptable work in essence is an absolute one that, in most cases, does not take into account personal conversion factors and hence does not recognise the individuality of each social assistance recipient. An alternative concept that could guide policymakers in practice, and that countries in principle have already agreed on, could be decent work. Decent work is a core topic of the International Labour Organization (ILO, 2008) and the eighth goal of the Sustainable Development Goals. The concept is focused on work that delivers a fair income, workplace security and social protection, but also opportunities for personal growth and social inclusion. If taken seriously, the objective of activation policy should be to have decent work. Revisiting this policy objective, as well as strengthening the links to closely related policies, such as wage policies, is particularly needed in light of the fact that in-work-poverty has become widespread across Dutch society (Goderis, van Hulst, Wildeboer Schut, \& Ras, 2018; Hoff, Goderis, van Hulst, \& Wildeboer Schut, 2018).

The common denominator of the empirical results is the notion that respondents want to be perceived and recognised as individuals with a unique past, present, and future who are placed in an intricate web of relations with significant others. From a policy perspective, the instances in which activation policy fails to acknowledge the interiority of a person and her vulnerability (cf. Sedmak, 2013) indicate that an approach that is dedicated to achieve a participatory society is not necessarily a strategy that leads towards social inclusion and promotes dignity. At the same time, the qualitative accounts provide important direct leverage points for policy changes, particularly with regard to the way in which caseworkers carry out their roles as policy mediators. Whereas citizens were clear about the social and communicative skills of activation workers that they experienced positively - being approachable, empathetic and respectful, supportive and motivating -, there needs to be a discussion around the extent to which these skills are already part of a professional identity of activation workers. 


\section{References}

Bartelheimer, P., Leßmann, O., \& Matiaske, W. (2012). Editorial: The capability approach: A new perspective for labor market and welfare policies? Management Revue, 93-97.

Blommesteijn, M., Kruis, G., \& van Geuns, R. (2012). Dutch municipalities and the implementation of social assistance: Making social assistance work. Local Economy, 27(5-6), 620-628.

Bonvin, J.-M. (2012). Individual working lives and collective action. An introduction to capability for work and capability for voice. Transfer: European Review of Labour and Research, 18(1), 9-18.

Bonvin, J.-M., \& Farvaque, N. (2006). Promoting capability for work: The role of local actors. In S. Deneulin, M. Nebel, \& N. Sagovsky (Eds.), Transforming unjust structures: The capability approach (pp. 121-142). Dordrecht, the Netherlands: Springer.

Bonvin, J.-M., \& Orton, M. (2009). Activation policies and organisational innovation: The added value of the capability approach. International Journal of Sociology and Social Policy, 29(11/12), 565-574.

Braun, V., \& Clarke, V. (2006). Using thematic analysis in psychology. Qualitative Research in Psychology, 3(2), 77-101.

Burchardt, T., \& Hick, R. (2016). The capability approach to advantage and disadvantage. In H. Dean \& L. Platt (Eds.), Social advantage and disadvantage (pp. 25-41). Oxford, United Kingdom: Oxford University Press.

Card, D., Kluve, J., \& Weber, A. (2010). Active labour market policy evaluations: A meta-analysis. The Economic Journal, 120(548), F452-F477.

Card, D., Kluve, J., \& Weber, A. (2018). What works? A meta analysis of recent active labor market program evaluations. Journal of the European Economic Association, 16(3), 894-931.

Carter, E., \& Whitworth, A. (2016). Work activation regimes and well-being of unemployed people: Rhetoric, risk and reality of quasi-marketization in the UK work programme. Social Policy \& Administration, 51 (5), 796-816.

Centraal Bureau voor de Statistiek. (2019). StatLine. Retrieved January 3, 2019, from https://opendata.cbs.nl/statline/\#/CBS/nl/

Chase, E., \& Walker, R. (2012). The co-construction of shame in the context of poverty: Beyond a threat to the social bond. Sociology, 47(4), 739-754.

Chase, E., \& Walker, R. (2014). The 'shame' of shame. In E. Chase \& G. Bantebya- 
Kyomuhendo (Eds.), Poverty and shame: Global experiences (pp. 161-173). Oxford, United Kingdom: Oxford University Press.

Dean, H. (2009). Critiquing capabilities: The distractions of a beguiling concept. Critical Social Policy, 29(2), 261-278.

Dean, H. (2016). Poverty and social exclusion. In H. Dean \& L. Platt (Eds.), Social advantage and disadvantage (pp. 3-24). Oxford, United Kingdom: Oxford University Press.

Egdell, V., \& Graham, H. (2017). A capability approach to unemployed young people's voice and agency in the development and implementation of employment activation policies. Social Policy \& Administration, 51(7), 1191-1209.

Elshout, J. (2016). Roep om respect. Ervaringen van werklozen in een meritocratiserende samenleving (Unpublished doctoral dissertation). Amsterdam Institute for Social Science Research, Amsterdam, the Netherlands.

Ezzy, D. (1993). Unemployment and mental health: A critical review. Social Science E Medicine, 37(1), 41-52.

Fraser, N., \& Honneth, A. (2003). Redistribution or recognition? A politicalphilosophical exchange. London, United Kingdom: Verso.

Frost, L., \& Hoggett, P. (2008). Human agency and social suffering. Critical Social Policy, 28(4), 438-460.

Fryer, D. (1986). Employment deprivation and personal agency during unemployment: A critical discussion of Jahoda's explanation of the psychological effects of unemployment. Social Behaviour, 1, 3-23.

Goderis, B., van Hulst, B., Wildeboer Schut, J. M., \& Ras, M. (2018). De SCPmethode voor het meten van armoede. The Hague, the Netherlands: Sociaal en Cultureel Planbureau.

Government of the Netherlands. (2016). Verplichtingen cliënten (Participatiewet, informatie voor gemeenten). Retrieved June 25, 2016, from https://www.rijksoverheid.nl/documenten/publicaties/2016/02/ 23/verplichtingen-clienten

Gubrium, E., \& Lødemel, I. (2014a). 'Not good enough': Social assistance and shaming in Norway. In E. Gubrium, S. Pellissery, \& I. Lødemel (Eds.), The shame of it: Global perspectives on anti-poverty policies (pp. 85-110). Bristol, United Kingdom: Policy Press.

Gubrium, E., \& Lødemel, I. (2014b). (Relative) poverty in a rich, egalitarian welfare state. In E. Chase \& G. Bantebya-Kyomuhendo (Eds.), Poverty and shame: Global experiences (pp. 188-200). Oxford, United Kingdom: Oxford University Press. 
Gubrium, E., \& Lødemel, I. (2014c). Towards global principles for dignity-based anti-poverty policies. In E. Gubrium, S. Pellissery, \& I. Lødemel (Eds.), The shame of it: Global perspectives on anti-poverty policies (pp. 199-220). Gubrium, Erika and Pellissery, S and Lødemel, Ivar: Policy Press.

Hirschman, A. O. (1970). Exit, voice, and loyalty: Responses to decline in firms, organizations, and states. Cambridge, MA: Harvard University Press.

Hoff, S., Goderis, B., van Hulst, B., \& Wildeboer Schut, J. M. (2018). Armoede in kaart 2018. Retrieved January 4, 2019, from https:// www.scp.nl/Publicaties/Alle_publicaties/Publicaties_2018/ Armoede_in_kaart_2018

ILO. (2008). ILO Declaration on social justice for a fair globalization adopted by the International Labour Conference at its ninety-seventh session, Geneva, 10 June 2008. Geneva, Switzerland: International Labour Organization.

Jahoda, M. (1982). Employment and unemployment: A social-psychological analysis. Cambridge, United Kingdom: Cambridge University Press.

Jahoda, M., Lazarsfeld, P. F., \& Zeisel, H. (1971). Marienthal: The sociography of an unemployed community. Chicago, IL: Aldine, Atherton.

Kampen, T. (2014). Verplicht vrijwilligerswerk: De ervaringen van bijstandscliënten met een tegenprestatie voor hun uitkering (Unpublished doctoral dissertation). University of Amsterdam, Amsterdam, the Netherlands.

Kampen, T., Elshout, J., \& Tonkens, E. (2013). The fragility of self-respect: Emotional labour of workfare volunteering. Social Policy and Society, 12(3), 427438.

Levitas, R., Pantazis, C., Fahmy, E., Gordon, D., Lloyd, E., \& Patsios, D. (2007). The multi-dimensional analysis of social exclusion. Bristol, United Kingdom: University of Bristol.

Lister, R. (2015). 'To count for nothing': Poverty beyond the statistics. Journal of the British Academy, 3, 139-165.

Lødemel, I., \& Moreira, A. (2014). Introduction. In I. Lødemel \& A. Moreira (Eds.), Activation or workfare? Governance and the neo-liberal convergence (p. 1-18). Oxford, United Kingdom: Oxford University Press.

Maastricht-Heuvelland. (2014). Beleidsplan Participatiewet Maastricht-Heuvelland 2015. Sociaal Domein.

Marttila, A., Whitehead, M., Canvin, K., \& Burström, B. (2010). Controlled and dependent: Experiences of living on social assistance in Sweden. International Journal of Social Welfare, 19(2), 142-151.

Migheli, M. (2011). Capabilities and functionings: The role of social capital for 
accessing new capabilities. Review of Political Economy, 23(1), 133-142.

Nussbaum, M. C. (2006). Frontiers of justice. Cambridge, MA: Harvard University Press.

Ohls, C. (2017). A qualitative study exploring matters of ill-being and well-being in Norwegian activation policy. Social Policy and Society, 16(4), 593-606.

Patrick, R. (2014). Working on welfare: Findings from a qualitative longitudinal study into the lived experiences of welfare reform in the UK. Journal of Social Policy, 43(4), 705-725.

Pellissery, S., Lødemel, I., \& Gubrium, E. K. (2014). Shame and shaming in policy processes. In E. Gubrium, S. Pellissery, \& I. Lødemel (Eds.), The shame of it: Global perspectives on anti-poverty policies (pp. 179-198). Bristol, United Kingdom: Policy Press.

Robeyns, I. (2005). The capability approach: A theoretical survey. Journal of Human Development, 6(1), 93-117.

Robeyns, I. (2017). Wellbeing, freedom and social justice. The capability approach reexamined. Cambridge, United Kingdom: Open Book Publishers. doi: http:// dx.doi.org/10.11647/OBP.0130

Sage, D. (2013). Activation, health and well-being: Neglected dimensions? International Journal of Sociology and Social Policy, 33(1/2), 4-20.

Sage, D. (2015). Do active labour market policies promote the well-being, health and social capital of the unemployed? Evidence from the UK. Social Indicators Research, 124 (2), 319-337.

Sage, D. (2018). Reversing the negative experience of unemployment: A mediating role for social policies? Social Policy and Administration, 52(5), 1043-1059.

Sage, D. (2019). Unemployment, wellbeing and the power of the work ethic: Implications for social policy. Critical Social Policy, 39(2), 205-228.

Schweiger, G. (2013). Recognition and social exclusion. A recognition-theoretical exploration of poverty in Europe. Ethical Perspectives, 20(4), 529-554.

Sedmak, C. (2013). Human dignity, interiority, and poverty. In C. McCrudden (Ed.), Understanding human dignity (p. 559-572). Oxford, United Kingdom: Proceedings of the Britisch Academy/Oxford University Press.

Sen, A. (1985). Well-being, agency and freedom: The Dewey lectures 1984. The Journal of Philosophy, 82(4), 169-221.

Sen, A. (1993). Capability and well-being. In M. Nussbaum \& A. Sen (Eds.), The quality of life (p. 30-53). Oxford, United Kingdom: Clarendon Press.

Sen, A. (2000). Social exclusion: Concept, application, and scrutiny. Social Development Papers, No. 1, Office of Environment and Social Development, Asian 
Development Bank.

Smith, M. L., \& Seward, C. (2009). The relational ontology of Amartya Sen's capability approach: Incorporating social and individual causes. Journal of Human Development and Capabilities, 10 (2), 213-235.

Sol, E., Sichert, M., van Lieshout, H., \& Koning, T. (2008). Activation as a socioeconomic and legal concept: Laboratorium the Netherlands. In W. Eichhorst, O. Kaufmann, \& R. Konle-Seidl (Eds.), Bringing the jobless into work? Experiences with activation schemes in Europe and the US (pp. 161-220). Heidelberg, Germany: Springer.

Strandh, M. (2001). State intervention and mental well-being among the unemployed. Journal of Social Policy, 30(1), 57-80.

Taylor, D. (2011). Wellbeing and welfare: A psychosocial analysis of being well and doing well enough. Journal of Social Policy, 40(4), 777-794.

Underlid, K. (2005). Poverty and experiences of social devaluation: A qualitative interview study of 25 long-standing recipients of social security payments. Scandinavian Journal of Psychology, 46(3), 273-283.

Underlid, K. (2012). Autonomy and poverty - an empirical study of long-term recipients of social assistance. In R. Laratta (Ed.), Social welfare (pp. 137152). Rijeka, Croatia: InTech.

van Berkel, R. (2007). Social assistance dynamics in the Netherlands: Exploring the sustainability of independence from social assistance via labour market inclusion. Social Policy and Society, 6(2), 127-139.

Vranken, J. (2001). Unravelling the social strands of poverty: Differentiation, fragmentation, inequality, and exclusion. In R. van Kempen \& H. T. Andersen (Eds.), Governing European cities: Social fragmentation, social exclusion and urban governance. (pp. 71-92). Aldershot, United Kingdom: Ashgate.

Wetenschappelijke Raad voor het Regeringsbeleid. (1987). Activerend arbeidsmarktbeleid. 's-Gravenhage, The Netherlands: Staatsuitgeverij. 



\section{Lost Agency? \\ Lived Experiences of Social Assistance Recipients in an Activating Welfare State}

\subsection{Introduction}

After unemployment rates had been comparatively low in countries of the European Union (EU) and the Organisation for Economic Co-operation and Development (OECD) before 2007/08, unemployment increased dramatically in the years following the economic and financial crisis. ${ }^{1}$ On average, unemployment rates rose by 2.5 percentage points both across EU and OECD member countries (Organisation for Economic Co-operation and Development, 2018). Over the same period, the long-term unemployment rate, defined as people who have been unemployed for twelve months or longer, was equally on the rise. Along with these developments, social spending, including benefits targeted to low-income households, unemployed persons or persons with disabilities, increased dramatically (Organisation for Economic Co-operation and Development, 2018). Measures that aimed at reforming the welfare-work nexus - often referred to as activation policies that aim to bring jobless people into work - gained particular prominence, though they had been in place in most OECD countries since the mid-1990s. Over the period 1980 to 2012, for instance, Knotz (2019) empirically showed for 21 OECD countries that, everything else being equal, the approach towards unemployed persons became stricter as unemployment rates rose and fiscal revenues decreased.

This chapter starts from two observations in this context. First, there is a dominant view that individuals out of work need to be activated. Policy reforms have included features that reduce the generosity of income support to strengthen work

1 I would like to thank all interview participants and Maastricht Heuvelland Social Services for their cooperation, and the administrative and financial support provided. Comments on earlier versions of this chapter were provided by Franziska Gassmann, Zina Nimeh, Keetie Roelen, and participants at the Welfare Conditionality Conference at York University from 26-28 June 2018. 
incentives, target work-first programmes at wider groups of beneficiaries, introduce increasingly stringent eligibility tests for benefit receipt, or implement stricter monitoring in combination with inducing or sanctioning certain behaviours. Moreover, enabling measures, such as training or education, are typically mandatory and noncompliance can be sanctioned (Molander \& Torsvik, 2015; van Berkel, 2010). What these types of reforms have in common is that they have sought solutions by way of individualising responsibility and requiring that people out of work change their behaviour. The term activation articulates the idea that individuals need to be made active, that benefit receipt alone without additional conditionality renders (or at least leaves) them passive. This leads us to think about the assumptions that are made about individuals' agency, referring to aspects of their decision-making, motivation, and capacity (Deacon, 2004). The currently prevailing view perceives the welfare subject as an actor who bears personal responsibility for his or her adverse life situation. Deficient behaviour needs to be induced or corrected by punitive action or conditional measures (Wright, 2012, 2016).

The second observation is that despite this dominant view and broad trend towards activation, countries have employed very specific mixes of activation policy instruments. A simple dichotomy between generous activation regimes that foster human capital formation and strict activation regimes that resort to coercion falls short from doing justice to the diversity of welfare states and substantial cross-national differences (cf. Aurich, 2011). Rather, countries typically build on idiosyncratic mixes of policy instruments that combine both enabling and demanding instruments to different degrees (cf. Marchal \& Mechelen, 2017), for instance in line with prevailing political positions and ideologies in a country, previous labour market trajectories, or the level of unemployment. Hence, despite a general consensus that individuals need to be activated, at the same time there are distinct and competing ideas on how this can be achieved.

Against this backdrop, this study asks the following questions: What are the links between different instruments of activation and recipients' agency? Under what conditions do activation instruments promote or limit recipients' agency? In brief, the argument is made that different activation instruments have varying, sometimes diametrically opposite effects on an individual's agency. An individual's agency is enhanced by elements that allow for autonomy of choice and create appropriate opportunity structures, namely adequate income replacement and high active support. Agency is limited by conditions and obligations imposed by codes of conduct and the non-availability of adequate opportunities and support. The empirical analysis 
draws on in-depth interviews with social assistance recipients. By building on lived experiences, this research changes the dominant perspective and lets policy users, rather than policymakers or policy implementers, express their voice.

The chapter contributes to the literature in two ways. First, the study contextualises the analysis of agency. It does so by recognising the hybrid nature of activation policies in terms of design of instruments and their potentially differing effects on recipients' agency. The chapter thereby adds to Carter and Whitworth's (2016) recent conceptual advances in the field that emphasised the need to link variations in recipients' well-being to different types of activation schemes. For that purpose, it draws on the literatures on activation typologies, models of agency in social policy, choice and autonomy, and the psychosocial effects of living in poverty and/or on welfare benefits. Second, this study provides new empirical evidence based on 45 semi-structured in-depth interviews with Dutch social assistance recipients. The analysis of recipients' agency within the context of activation policy challenges the implicit assumptions that influence policy discourse, design, and delivery in the Netherlands. This adds to the knowledge base of authentic accounts of social assistance recipients' experiences in the Dutch welfare state (Elshout, 2016; Kampen, 2014; Kampen, Elshout, \& Tonkens, 2013), yet with a specific focus on the enactment of individual agency within the social fabric in which it is produced. The study complements research on lived experiences in other countries, particularly the United Kingdom (e.g. Patrick, 2014; Wright, 2016) as a liberal welfare state or Norway (Gubrium \& Lødemel, 2014; Ohls, 2017) as a social-democratic type of welfare state with experiences from a conservative-corporatist type (Esping-Andersen, 1990).

This chapter comprises seven sections. In the next section, the conceptual framework is specified. This leads to hypotheses about how different instruments of activation should be linked to individuals' agency. The third section specifies the design of activation in the Dutch case. The fourth section explains the research method and the fifth section reports the results. The final sections discuss the main points of tension between the Dutch model of responsibility and recipients' lived experiences.

\subsection{Conceptual Framework: Activation and Agency}

The wide use of the terms activation and agency by different authors has led to some ambiguity. This section first sets the stage by presenting a typology of activation 
policy instruments. It then introduces the understanding of agency used in this study and presents the expected links between different activation elements and a welfare recipient's agency.

\subsubsection{Activation Typologies}

Activation refers to the "policy of designing benefit rules and employment/training services with a view at moving unemployed income benefit recipients into work" (Lødemel \& Moreira, 2014, p. 8). This definition distinguishes activation from active labour market policies that can be a subset of activation strategies, but are usually not concerned with eligibility criteria for the receipt of benefits. Activation is also broader than workfare, as additional options such as training or job search assistance are available (Lødemel \& Moreira, 2014).

The proliferation of interventions directed to the activation of recipients in combination with considerable cross-national variation inspired a literature that has studied questions of policy convergence across countries. The activation typologies that have been developed for this matter, particularly the more instrument-oriented ${ }^{2}$ classifications of activation (cf. Marchal \& Mechelen, 2017), are helpful in identifying different elements of activation. The literature typically differentiates between interventions to increase job search efforts and job take-up, and approaches that foster human capital development through education and training. The former approach incentivises or mandates behavioural change by means of the duration or level of benefits, the prescription of individual activity requirements, and/or sanctioning clauses. This approach has been denoted as a demanding, incentive-centred, or recommodifying approach (cf. Dingeldey, 2007; Eichhorst, Kaufmann, Konle-Seidl, \& Reinhard, 2008; Marchal \& Mechelen, 2017). The latter strategies are more concerned with increasing an individual's employability and have been labelled as enabling, human capital formation, or investment approaches (Dingeldey, 2007; Eichhorst et al., 2008; Marchal \& Mechelen, 2017).

Although it is generally acknowledged that countries use various strategies, this dichotomy hinders deeper understanding of mixed cases. Such cases form the focus of this study that looks at varying effects of different elements of an activation policy on a recipient's agency. For that purpose, it is expedient to look at activation

2 Other classifications are for instance based on basic principles, target groups, or aspects of governance. 
dimensions to emphasise mixed cases (Aurich, 2011; Bonoli, 2010, 2011; Dingeldey, 2007). Aurich's (2011) conceptual framework (Figure 3.1) is used, as her definition of activation is similar to the definition presented here. The framework distinguishes between the degree of active support on the horizontal axis and incentive construction on the vertical axis. Incentive construction ranges from granting autonomy to coercion. Autonomy is granted via social rights and refers to income replacement and the encouragement of activities that increase options between welfare receipt and employment. Coercion, in turn, counterbalances these autonomy effects by means of attaching conditions to benefit receipt. Examples of conditions are the definition of reasonable jobs, the code of conduct that specifies what (job search) behaviour is expected, and the sanctions that apply in cases of non-compliance. The degree of active support, on a continuum from low to high, is determined in light of the activities offered and aspects of case management and guidance.

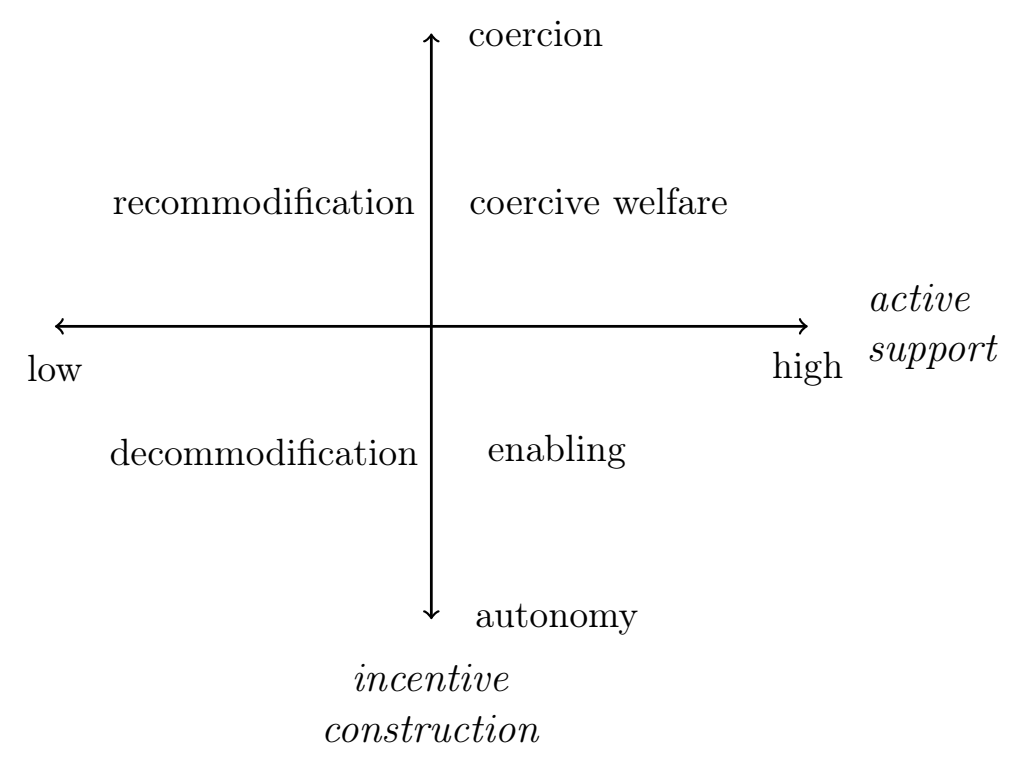

Figure 3.1: Aurich's two dimensions of activation

Source: Aurich (2011, p. 301).

The upper left and lower right quadrants reproduce the dichotomy presented above in the sense that they are either incentive-centred (recommodification) or promote human capital formation (enabling). The lower left quadrant refers to an approach of decommodification. Income replacement is generous and there is no active support at all. The upper right quadrant represents a hybrid case. Coercive welfare combines elements of creating incentives for benefit exit and increasing employability. 
This typology serves two purposes. First, it is employed to hypothesise how variations in incentive construction and active support can be linked to variations in agency. Second, it is used to organise the instruments that are included in Dutch activation policy in Section 3.3. Before that, the following section discusses models of agency and presents the conception of agency that is used in this study.

\subsubsection{Models of Agency in Social Policy}

When scholars refer to agency, they are usually concerned with "purposive human action or behaviour" (Deacon, 2004, p. 447) which includes aspects of decisionmaking, choice, motivation, and capacity. One strand of literature, presented as the dominant model of the "active welfare subject" by Wright (2016, p. 235), is guided by the assumption that welfare benefit recipients are inherently inactive. They are immoral, but rational (Murray, 1984) or "dutiful but defeated" (Mead, 1992, p. 133). These conceptions are associated with terms such as welfare dependency and underclass or categories of moral worth such as the undeserving poor. In any case, as inactivity is perceived as the core of the problem, the inferred policy solution is to transform passive recipients into active ones. This is achieved either through incentive structures or coercion in a prescriptive top-down manner. What exactly the active subject is supposed to look like, however, remains ambiguous and uncertain. In the context of activation policies, it is either seen as the docile subject that accepts or at least tolerates the behaviour prescribed by the state or, on the other hand, as the entrepreneurial self that proactively manages risks and opportunities (Whitworth, 2016).

Critics of this view observe the alleged passivity of benefit recipients and their unapproved conduct in the context of disempowering narratives of a socially constructed, denigrated "Other" (Lister, 2004, 2015). Othering denotes the processes by which the more powerful 'non-poor' demarcate themselves from the 'poor' and create, maintain, and justify a social distance between 'us' and 'them'. Accompanied by processes of stigmatisation and stereotyping, the individual experience of poverty becomes a shameful, demeaning, and humiliating one that is structurally embedded. Lister (2004) advocated for an understanding of poverty as both a material and a relational-symbolic phenomenon. Her work is of particular relevance for this study as she acknowledged the capacity to act of people who live with poverty, and the structural constraints and financial insecurity within which their agency is enacted. 
Lister $(2004,2015)$ presented a typology of four forms of agency that can be used as a conceptual lens to organise agency exercised by people living in poverty. These four forms are organised along two axes: the personal-political/citizenship axis and the strategic-everyday axis. On a personal level, everyday activities include the often completely unrecognised, but demanding and time-consuming 'getting by' on a low income. On a political level, everyday activities encompass different forms of informal resistance as 'getting (back) at'. Strategic expressions of individual agency include personally 'getting out' of poverty, for instance by means of education or seeking paid employment, as well as 'getting organised'. The latter refers to forms of collective action such as collective self-help or political activities in order to challenge the circumstances of living in poverty. The focus of this typology is on actions rather than actors. The same individual can exercise different forms of agency at different times or in different domains of life. In general, individuals are considered to be reflexive and creative agents who react to and act within structural constraints and power relations. Although Lister's work refers to poverty in general, a more focused view on social assistance recipients' agency does not require any adjustments to the four forms of agency (cf. Patrick, 2017, p. 64).

Lister's $(2004 ; 2015)$ focus on the creativity and resourcefulness of the welfare subject stands in stark contrast to the emphasis on pathologies in the dominant model. But not all forms of agency are per se good and constructive either for oneself or for other people. A focus on the positive capacities of the welfare subject is to be welcomed, but a robust model of agency cannot turn away from negative capacities and needs to incorporate them in a critical and realistic way. This is the line of argument of Hoggett (2001). Hoggett (2001) developed a model of agency that accommodates both the creative, reflexive agent, and positions of victim and "own worst enemy" (p. 37). In his work, Hoggett (2001) described a continuum of empowerment. The self-as-agent, on the one end, is able to shape his or her circumstances. The self-as-object, on the other end, has little control over the surroundings. Hoggett (2001) furthermore distinguished that both the self-as-agent and the self-as-object might either act in a non-reflexive way on impulse or consciously and calculated in a reflexive way.

In summary, Lister's (2004; 2015) taxonomy is a useful device to understand agency of social assistance recipients who have to manage living on tight budgets, but at the same time are expected to graduate from social assistance into work. It categorises different forms of their agency along the personal-political and the everyday-strategic axes. However, the taxonomy is mainly concerned with the self- 
as-agent. In order to understand incapacity to act, this study refers to Hoggett's (2001) model of agency as a continuum ranging from self-as-object to self-as-agent. To promote or to limit agency therefore means to move along this continuum, including both reflexive and non-reflexive agency. Both Lister and Hoggett emphasise that they refer to actions rather than individuals. This means, there can not only be variations in agency over time, but also variations regarding different aspects of life at the same point in time. It is therefore possible to hypothesise that different elements of activation can have varying effects on a recipient's agency. The following section links activation policy instruments and agency.

\subsubsection{Links Between Activation and Agency}

The two previous sections established the ways in which both variations in strategies within one activation policy and variations in agency are possible. This section discusses the expected links between variations in activation and agency. These are derived from literature on choice and autonomy (cf. Burchardt, Evans, \& Holder, 2015; Burchardt \& Holder, 2012) as well as Fryer's (1986) agency theory of the psychological impact of unemployment.

For the first dimension of Aurich's (2011) conceptual framework, incentive construction, it is expected that coercive policy elements reduce individual agency. Elements such as the definition of reasonable jobs, individual activity requirements, or sanctions limit choice and overrule an individual's preferences and values (cf. Burchardt et al., 2015; Burchardt \& Holder, 2012). In a related vein, Fryer (1986) emphasised the desire for self-directedness, sense-making, and autonomy in the fulfilment of an active social agent's needs. According to Fryer, the capacity to exercise agency may also be restricted to varying degrees for people in employment and lead to feelings of frustration. Yet, frustration of agency is predicted to be exacerbated in a situation of relative material poverty, stigma, and pressure from others. Linking the receipt of welfare benefits to fulfilling certain conditions can also induce shame (Pellissery, Lødemel, \& Gubrium, 2014) which equally inhibits agency (Walker et al., 2013). Conversely, policy elements that grant autonomy contribute to strengthening an individual's agency. For the second dimension, degree of active support, a person's capacity to act and to make choices is determined by the available opportunity structure (Burchardt \& Holder, 2012). The perceived and actual range of available options of active support is assumed to strengthen an individual's agency. A lack of such options limits agency. 
Overall, it is expected that an individual's agency is promoted the more a policy instrument or a combination of policy instruments grant autonomy while offering high levels of active support. In an enabling regime, agency both in terms of 'getting by' and 'getting out' is expected to be enhanced, whereas a pure recommodification type of policy is expected to have detrimental effects on an individual's agency. In the hybrid coercive welfare case, individual's agency is assumed to vary in line with the included policy elements. For instance, it is expected that mandatory placements yield ambiguous impacts depending on whether the aspect of coercion or of active support is more strongly perceived by the individual recipient. This is suggested by previous research in the Netherlands with workfare volunteers (Kampen \& Tonkens, 2019). The way in which the request to volunteer was presented was crucial for whether or not recipients felt empowered or disempowered.

Both Lister $(2004,2015)$ and Hoggett (2001) pay close attention to the role of structural constraints and power relations in the exercise of agency. In terms of structural conditions, this requires attention to the limits of agency that are imposed by the personal situation in relation to the labour market and society at large. In terms of power relations, this warrants particular attention to interactions with caseworkers and the ways in which these interactions mediate agency. Agencyreducing effects of coercive activation elements are expected to be intensified when labour markets in a certain profession are weak, or when efforts are not met with success for an extended period of time. Equally, the effect of interactions with the caseworker are assumed to depend on the extent to which caseworkers emphasise coercive elements or active support with room for self-directed choice (Kampen \& Tonkens, 2019).

This section discussed the theoretical links between variations in activation and agency. In the following section, Aurich's (2011) framework is applied to the Dutch context. This leads to specific hypotheses about how the design of Dutch social assistance policy is expected to be linked to social assistance recipients' agency, and under what conditions activation is assumed to promote or limit a recipients' agency.

\subsection{The Dutch Case}

Before presenting the specific activation policy instruments that were in place at the time of this study, a brief discussion of the prevalent policy discourse in the Netherlands sets the stage. 


\subsubsection{Responsibility Talk in the Netherlands}

An appeal to citizens' own sense of responsibility both in rhetoric and practice has set the tone in the Dutch welfare state throughout the past decades (Peeters \& Drosterij, 2011; Veldheer, Jonker, Van Noije, \& Vrooman, 2012; Verhoeven \& Tonkens, 2013). The move from a logic of social protection towards a logic of self-responsibility (Sol, Sichert, van Lieshout, \& Koning, 2008) has formed part of the evolution towards a "new model of responsibility" (Vrooman, Van Noije, \& Veldheer, 2012, p. 19). The state mandates, monitors and sanctions behaviour, yet its realisation is left as far as possible to the citizen. At the same time, public entitlements are reduced. This means, increased individual responsibility, but on terms prescribed by the state (Peeters, 2013; Peeters \& Drosterij, 2011; van Echelt \& Josten, 2012).

Though the Dutch activation policy has always included elements of both enabling and incentive-centred strategies (Marchal \& Mechelen, 2017; Spies \& van de Vrie, 2014), the introduction of the Participation Act in 2015 has further reinforced the latter. In line with developments in other advanced economies, the Netherlands have undergone transformations towards an activating welfare state. Over the last two decades, major adjustments to the legislation in the field of social assistance have redefined the distribution of responsibilities along two dimensions (Sirovátka \& Sol, 2013; van Berkel, 2007, p.48). This has entailed the shift of responsibilities and roles from the national level towards the municipalities and the market, as well as the increasing emphasis on the responsibility of beneficiaries vis-à-vis the state. Milestones of this development were the 1996 Social Assistance Act and the Work and Social Assistance Act in 2004, that spelt out the credo of 'work above income'. The most recent change occurred in January 2015 with the introduction of the Participation Act. It replaced the Work and Social Assistance Act and the Sheltered Employment Act as well as large parts of the Young Disabled Persons Act with the aim of maximising labour market participation, including of individuals with limited work capacity.

The detailed obligations for social assistance recipients as spelt out in the Participation Act are illustrative of the "new model of responsibility" (Vrooman et al., 2012 , p. 19). The state defines narrowly what it considers responsible behaviour on the side of the recipient to move into regular employment. Further, the state monitors recipients' efforts and has means to sanction deviant behaviour. In this regard, van Echelt and Josten (2012) observed a shift in the role of the state from caring to disciplining. They noted that this shift was illustrated by stricter condi- 
tions imposed on social assistance recipients, increasing distrust against this group, as well as different perceptions of the working as compared to the non-working population. This is in line with the notion of Othering implicit in the dominant model of the active welfare subject and mirrors earlier developments in the United Kingdom (Dwyer, 1998). This development has been met with some resistance by activation policy implementers. Several local welfare agencies have been planning field experiments with more flexible rules (such as no obligation to search for job or additional support if requested) based on a different understanding of human motivation, decision-making and choice, or trust and personal autonomy (Gemeente Utrecht, 2019; Groot, Muffels, \& Verlaat, 2019; Kremer, van de Meer, \& Ham, 2017). Further, the Dutch public is divided over this issue. 57 per cent of respondents in a representative survey on personal responsibility in 2012 agreed with the statement that individuals had to be more personally responsible for their well-being and should rely less on public provisions (den Ridder \& Dekker, 2012, p. 285). Compared to results from 1995, there was a tendency towards supporting stricter job search requirements for social assistance recipients, including single parents and older recipients (van Echelt \& Josten, 2012, pp. 102-103).

\subsubsection{Policy Instruments}

In line with Aurich's (2011) conceptual framework, the current activation policy instruments are presented along the two dimensions of incentive construction and degree of active support.

With respect to the dimension of incentive construction, autonomy is granted through income replacement. In the Netherlands, the level of social assistance is tied to the national minimum wage. Furthermore, it depends on the existence of additional income sources, household composition and the age of the recipient. In 2016, a person aged 21 or above who lived alone received 70 per cent of the national minimum wage (Government of the Netherlands, 2016a). Based on data from 2012, the Dutch social assistance scheme was the most generous one in comparison to other EU countries (Marchal \& Mechelen, 2017). It fell slightly short of reaching 60 per cent of median equivalent household income which marks the European at-riskof-poverty threshold as a criterion for guaranteeing adequate income (Marchal \& Mechelen, 2017). Contrary to a majority of OECD countries, there was no declining trend in the adequacy of minimum income protection between 1990 and 2012 (Noël, 2019). 
The level of autonomy provided through income replacement is counterbalanced by several conditions attached to benefit receipt (Government of the Netherlands, 2016b). With the introduction of the Work and Social Assistance Act in 2004, the definition of a reasonable job was changed from a fitting job to a commonly acceptable job (Spies \& van de Vrie, 2014). The code of conduct for social assistance beneficiaries includes obligations regarding the acceptance and maintenance of work; individual efforts to increase employability through acquisition and/or maintenance of necessary skills, participation in reintegration activities, and appropriate behaviour and appearance; and signing up at temporary employment agencies upon request (Government of the Netherlands, 2016b). In addition to obligations that aim at increasing chances to find employment, social assistance receipt is conditional on engaging in activities in return for benefits, a quid pro quo requirement. Activities in return for benefits are explicitly not aimed at increasing employability and often take the form of (compulsory) volunteer activities. They are not permitted to jeopardise any reintegration efforts nor substitute regular workplaces. Non-compliance of recipients with these obligations can be sanctioned by a withdrawal of benefits for up to three months. Discretionary adjustments in line with individual circumstances are possible.

The provision of active support to social assistance recipients is the responsibility of the municipal welfare agencies. In Maastricht, for example, a joint policy framework with five other municipalities sets out the principles and instruments for the assessment, placement, and personal development of beneficiaries. The assessment of specific needs and work capacity on a scale from 0 to 100 per cent is used to assign beneficiaries to one of four categories that form the basis for the subsequent placement. Instruments for placement intervene either at the employer or the beneficiary side. In the former case, premiums aim to incentivise employers to recruit social assistance recipients, and subsidies compensate for productivity losses due to employment of individuals with less than 100 per cent work capacity.

On the social assistance recipient side, different forms of work are foreseen according to an individual's work capacity. These range from activities to spend the day meaningfully, to sheltered employment, working while retaining benefits, and subsidised employment. Working while retaining benefits aims at directing social assistance recipients towards the labour market, for instance through internships to increase work experience or employee skills, or participation placements with the aim of promoting participation, social activation, personal development, and employability. Typical examples are care tasks in retirement homes or administrative 
duties in non-for-profit organisations. The fact that participation in reintegration activities are prescribed in the code of conduct as a form of active support exemplifies the contested nature of instruments in terms of being enabling or demanding. Table 3.1 summarises Dutch activation policy instruments and their expected links to individual agency in line with the conceptual framework presented in the previous section.

Table 3.1: Links between Dutch activation policy and agency

\begin{tabular}{|c|c|c|}
\hline $\begin{array}{l}\text { Dimension of } \\
\text { activation }\end{array}$ & Activation policy element & $\begin{array}{l}\text { Link to } \\
\text { agency }\end{array}$ \\
\hline \multirow[t]{4}{*}{$\begin{array}{l}\text { Incentive } \\
\text { construction }\end{array}$} & $\begin{array}{l}\text { Income replacement (social assistance benefits } \\
\text { defined at national level): }\end{array}$ & \multirow{2}{*}{$\begin{array}{l}\text { En- } \\
\text { hance/not } \\
\text { limit } \\
\text { agency }\end{array}$} \\
\hline & 70 per cent of minimum wage & \\
\hline & Coercive elements (nationally defined): & \multirow{2}{*}{$\begin{array}{l}\text { Limit } \\
\text { agency }\end{array}$} \\
\hline & $\begin{array}{l}\text { Definition of reasonable job: acceptable job } \\
\text { Code of conduct: Acceptance of offered } \\
\text { work, appropriate behaviour to find work } \\
\text { (e.g. application requirements, physical } \\
\text { appearance), participation in reintegration } \\
\text { activities and activities in return for benefits } \\
\text { - Sanctions: e.g. withdrawal of benefits for } \\
\text { one to three months }\end{array}$ & \\
\hline \multirow[t]{2}{*}{$\begin{array}{l}\text { Degree of } \\
\text { active support }\end{array}$} & $\begin{array}{l}\text { Instruments/activities (defined at municipal } \\
\text { level): }\end{array}$ & \multirow{2}{*}{$\begin{array}{l}\text { En- } \\
\text { hance/limit } \\
\text { agency } \\
\text { depending } \\
\text { on degree } \\
\text { to which } \\
\text { they are } \\
\text { offered }\end{array}$} \\
\hline & $\begin{array}{l}\text { - Instruments for diagnosis } \\
\text {. Job mediation (e.g. application training) } \\
\text {. Personal development (e.g. further } \\
\text { education or training, internships) } \\
\text {. Other forms of work (e.g. sheltered } \\
\text { employment) }\end{array}$ & \\
\hline
\end{tabular}

Source: Author's own elaboration.

\subsection{Research Method}

The empirical analysis draws on 45 semi-structured in-depth interviews with social assistance recipients in Maastricht held between October 2015 and May 2016. 
Maastricht is a southern Dutch city with roughly 120,000 inhabitants. ${ }^{3}$ In 2015, the unemployment rate in Maastricht was 7.3 per cent, which was close to the rate in the province and the national rate. The proportion of social assistance recipients in the municipality (47 social assistance recipients per 1,000 inhabitants aged 15 to 65 ) is comparable to other municipalities in the Netherlands with more than 100,000 inhabitants. The regional labour market structurally changed in recent decades. It has evolved away from the manufacturing towards the service industry.

The inclusion criteria were to receive a social assistance benefit governed by the Participation Act through the local Social Services office at the time of the interview; to be older than 17 years; and to be legally competent. The voluntary character of the study was emphasised, particularly that non-participation had no negative repercussions on benefit receipt. The initial sampling strategy of stratified random sampling based on anonymized administrative data was used to reach out to 159 individuals. Low response rates despite a follow-up by phone meant that complementary strategies were necessary, namely snowball sampling, contacts via social workers, and contacts via local neighbourhood and Social Services centres. Table 3.2 describes the socio-economic characteristics of respondents and compares them to the population of social assistance recipients in Maastricht as of July 2015. Based on observable characteristics, respondents tend to be older, are more often unmarried, and have completed more advanced educational degrees than the average social assistance recipient in Maastricht. This study therefore does not intend to make any claims of representativeness. Rather, the sample depicts diversity in terms of exogenous socio-economic characteristics (except for the age group of 18 to 27) and hence it is possible to explore the variety of lived experiences, intentions, and actions of social assistance recipients across these characteristics.

The term 'lived experience' is used to refer to respondents' subjective, situated, and direct experience that is gained through first-hand involvement. This contrasts with experience that is constructed or mediated by other people. McIntosh and Wright (2019) discussed the problem that a focus on highly individual experiences might challenge the generalisability of these accounts. Nonetheless, these experiences refer to and combine both the ordinary and the extraordinary (cf. Abrahams, 1986, cited in McIntosh and Wright (2019, p. 460)). The analysis therefore looks for the "typicality", "shared typical" (McIntosh \& Wright, 2019, p. 460) or commonalities in the accounts of individuals in similar situations. Finally, the term is also used as

3 All figures in this section are retrieved from Statistics Netherlands (Centraal Bureau voor de Statistiek, 2019). 
Table 3.2: Sample characteristics (in per cent)

\begin{tabular}{lrr}
\hline \hline & Sample & $\begin{array}{r}\text { Population of social } \\
\text { assistance recipients in } \\
\text { Maastricht }\end{array}$ \\
\hline Age (in years) & & \\
18-27 & 2.2 & 7.5 \\
$28-44$ & 26.7 & 35.1 \\
$45+$ & 71.1 & 57.4 \\
Male & 42.2 & 43.9 \\
Dutch & 86.7 & 85.5 \\
Foreign background & 12.0 & n.a. \\
Education & & 4.9 \\
No primary education & 0.0 & 30.8 \\
Primary education & 8.9 & 46.9 \\
Secondary education & 68.9 & 7.7 \\
Tertiary education & 22.2 & 9.9 \\
Unknown & 0.0 & \\
Civil status & & 44.9 \\
Never married & 53.3 & 22.0 \\
Married & 11.1 & 1.5 \\
Widowed & 4.4 & 31.7 \\
Divorced & 31.1 & 59.5 \\
Household composition & & 23.9 \\
One-person household & 64.4 & \\
Single-parent household & 15.6 & \\
Couple & 20.0 & \\
\hline \hline
\end{tabular}

Source: Administrative data provided by Social Services Maastricht Heuvelland.

Notes: Figures for the population of social assistance recipients in Maastricht refer to July 2015.

a "strategy of recognition" (McIntosh \& Wright, 2018, p. 456; D. E. Smith, 1987) that is mindful of feelings or interactions that tend to be ignored.

Semi-structured interviews were chosen to allow respondents to compile their own narratives along a series of key topics based on the study's objectives: experiences with living on social assistance in financial and social terms, including feelings of societal belonging (the personal and everyday dimension of 'getting by'); the meaning of work, the current job search process and experiences with reintegration activities, and dreams and expectations for the future (the personal and 
strategic dimension of 'getting out'). Through open-ended questions and appropriate probing questions, detailed and contextualised accounts of beneficiaries' lived experiences and how people gave meaning to their activities and activities of others were collected. At the same time, this made room for newly emerging themes. A supplementary questionnaire at the end of the interview gathered basic data on demographic profiles. Interviews were held in neighbourhood centres or at respondents' participation placements. Interviews lasted between 20 and 140 minutes. The typical length ranged between 35 and 60 minutes. All interviews except for one (during which notes were taken) were recorded and transcribed verbatim. Interviews were anonymised before continuing with data analysis. Transcription and data analysis were performed with the qualitative data software NVivo. Interviews were conducted and analysed in Dutch and only quotations that are included in the chapter were translated into English. Ethical approval was obtained prior to the interviews from Maastricht University and ethical considerations were respected throughout the study. All names that are used in this chapter are pseudonyms.

The transcripts were analysed using a thematic analysis, which aims at identifying and analysing recurring patterns and describing the data in detail (cf. Braun \& Clarke, 2006). The research questions and the conceptual framework placed the focus on more specific themes, with the objective of providing a more detailed account of this group of themes instead of a description of the entire dataset. The themes were mainly identified based on the analytical interest (theoretical thematic analysis). The analysis went beyond what respondents had explicitly said, but looked for underlying conceptions or ideas as latent themes.

Data analysis followed the process suggested by Braun and Clarke (2006). Detailed familiarity with the data was achieved by being present at the interviews, transcribing all data and finally reading and re-reading the data items. The coding was based on the conceptual framework described in the previous section. To illustrate, the self-as-agent could manifest itself through the dimensions of 'getting by' and 'getting out'. Codes related to the theme of 'getting by' on a daily basis were financial strategies (individuals spoke about strategies to deal with their financial situation, for instance creativity or resourcefulness) and social strategies (individuals referred to strategies to cope with their social situation). 'Getting by' was finally maintained as a theme. In addition, factors that expanded or limited agency were coded, with codes referring to the different elements of activation policy (namely different types of placement instruments, income support, requirements, caseworkers), as well as perceptions of the labour market situation, employers' discrimination 
based on age, and the perceived views of others, such as family and friends or people in employment.

From the stage of initial coding and throughout the refinement of the codes, the relationship between codes related to agency, to activation policy instruments, and to factors that expanded or limited agency were considered. In the course of data analysis, it became apparent that it was not only necessary to take into account that different instruments can have different effects on an individual's agency, but also that the effects could change over time. The theme of 'getting out', for instance, was refined in order to understand to what extent strategies might have changed over time. In this respect, it was important that respondents' accounts were repeatedly read en bloc. This ensured that the integrity of individual accounts was respected and that data extracts were always put in context. This strategy also allowed us to integrate the stories and patterns told within individual themes and to relate them to the overall research questions.

\section{$3.5 \quad$ Findings}

\section{"I simply had no choice"}

Take-up of social assistance benefit was usually preceded by one or sometimes more negative life events. These were characterised as being beyond recipients' personal control and entailing some sort of loss: loss of job or enterprise due to adverse economic circumstances, loss of good health, loss of partner through divorce or death, or persecution in the country of origin leading to loss of the previous home. In stark contrast to a discourse on lifestyle choices and personal responsibilities prevalent in the dominant model, respondents typically described the take-up of social assistance as last resort after they had explored and exhausted all other alternatives. Sometimes, they took this step only with great reluctance. Perceptions of self-as-object rather than of self-as-agent in this situation were conveyed in words and terms such as 'constrained', 'limited', 'not free', 'dependent' or 'having no choice'.

For some individuals, the benefit application process and the initial meeting at the Social Services office were experienced as a profound intrusion in their privacy, as humiliating and imposing a psychological toll on them and, particularly, as putting blame on them. "As if you had committed a crime. And the crime is to apply for your social assistance benefit", as Thomas $(45+)$ put it. Against this background 
of the onset of benefit receipt perceived as an unavoidable event that leaves the individual in an emotionally vulnerable state and threatens personal integrity, the links between elements of incentive construction, active support, and agency are explored.

\section{Imposed inactivity}

At the beginning of the interview, we asked respondents about their typical day. They usually sketched structured days that were filled with a number of activities. Many of our interview partners worked at participation placements or volunteered several days per week. In addition, respondents looked for jobs, took care of their children or relatives, kept medical appointments, or engaged in their hobbies.

Already at this early point and continuing throughout the interviews, the prevalent narrative was a strong preference for being active and involved. Contrary to the presumed passivity in the dominant model, many respondents commented that they could not bear just sitting at home, that they were not used to doing nothing, or that they thought that is was unhealthy for people to do so. Several people also felt that mental or physical health problems forced them to be inactive. A looming fear was that of becoming inactive as a consequence of job loss or ill-health, and of entering a downward spiral that could, in the worst case, end in depression - a state that was described in ways that were reminiscient of Hoggett's (2001) self as non-reflexive object. Respondents who had come as asylum seekers to the Netherlands remembered extreme examples of imposed inactivity, when any possibility to shape their environments was strongly restricted. While they had been waiting for their residence permits for up to several years, they had not been allowed to work or study at all. This led to frustration, desperation, or feelings of panic.

Income replacement as a right?

The majority of respondents agreed that the level of income replacement was sufficient to satisfy basic necessities, albeit not allowing any leeway to accommodate unexpected expenses or afford any extras. As pointed out by Lister (2004, 2015), it was in this context of narrow margins of financial freedom that many respondents demonstrated their capacity to act in resourceful ways to 'get by'. They referred, often with pride, to their ability to manage tight budgets, to find creative ways to 
produce things by themselves, and to be able to make conscious choices. Others actively struggled to be a good parent despite limited financial means, for instance by ensuring that their children were involved in social activities even by sacrificing their own needs. At the same time, for a few respondents it was finally a relief to receive a social assistance benefit because of its regularity and predictability. This was usually related to previous experiences with debts. In some other instances, respondents said that they were grateful that such a social safety net existed, which in part was related to situations in other countries.

In several interviews, it became apparent that social assistance benefits were not perceived or experienced as a right. This was observed in a range of situations, all of which can be understood as limiting individual agency. First, some people had the feeling that they had to ask for money. This made them feel dependent, not free, or took away control from their lives. Against this backdrop, some respondents expressed the idea that they wanted to do something in return for their benefit - an action that relieved them from the role as passive recipient and created a feeling of reciprocity and deservingness. Second, and in a related vein, the daily experiences of living on social assistance were shaped by processes of Othering. It was perceived that the society viewed welfare recipients as lazy profiteers and spongers, free-riding on tax payers and deliberately choosing not to work. Externally instilled feelings of stigma and shame coalesced with and potentially heightened negative internal evaluations of the self. In a few other cases, finally, this feeling was instilled by employees at the Social Services office. One example was given by Peter $(45+)$, who felt that income replacement was not framed as a social right, but presented as the result of irresponsible behaviour by 'them': "It is your fault, and you also have to solve it. And if you don't solve it quickly, then you are doing something wrong."

\section{'Responsible behaviour' within structural constraints}

If their current health situation or care responsibilities allowed it, many respondents engaged in strategic actions to 'get out' of social assistance. The motivation to exit from benefit receipt was related to a range of factors, including freedom from intrusion in your private sphere and hence regaining control over your life. More specifically, it was associated with more financial leeway - often also linked to considerations of participation in societal activities - and additional values attached to employment. These included social contacts, contributing your skills to a collective purpose, activity and structure (cf. Jahoda, 1982), or personal development. 
In their narratives, respondents mentioned a number of factors that limited their capacity to act in the personal/strategic domain of getting out of benefits. In the first instance, the factors they described were unrelated to the activation policy. A recurring topic was that of perceived employer discrimination based on age, that was raised by virtually every participant above the age of 44 . Moreover, poor health prevented many respondents from working full-time or from continuing their previous, often physically demanding jobs. Finally, both low- and high-skilled respondents commented on weak labour market demand in their sectors at the time of the interview. In this context, the intensity with which respondents looked for new jobs varied. Respondents who had already lived on social assistance for an extended period of time described a process during which the intensity of their job search activities and their motivation had gradually waned. Frustration and disappointment due to the constant experience of rejections were named as reasons, as by Wilma $(45+)$ :

"You become demoralised. At the beginning you jump on everything, you apply for everything that you think could somehow work. Yet, also because of reactions to your application such as: 'We have no use for you. We get better [emphasis] letters and your training is not good..."'

Nonetheless, this pervasive perception of constraints beyond personal control did not per se lead to inaction. Rather, a range of examples illustrated respondents' ability to reflect on their job search process hitherto and related emotions, and to incorporate these insights into future strategies to get out of benefits. Instead of randomly 'jumping on everything', these respondents had started to adjust their strategies in line with their personal situation and experiences and the perceived labour market situation. This included applying solely for jobs that matched their interests or where the chances of success were perceived as realistic in order to "incur no additional frustration", as Jane $(45+)$ explained. Others identified job leads not only using a combination of traditional job search channels, but also in more creative ways. For instance, they sought job opportunities that were not yet advertised in and beyond the region based on media coverage. Moreover, strategies to get out entailed thinking about further education, training or work experience that could increase employment chances and, last but not least, options for setting up your own enterprise. All of these strategies are illustrative of creative agents.

Precisely these individually devised strategies to get out in response to perceived 
structural constraints could conflict with incentive-related elements of Dutch activation policy. These coercive elements could prompt movements from self-as-agent aiming to react to and influence the environment in a meaningful way - towards selfas-object, where options to shape your environment become further limited. This pertained to, first, the definition of acceptable jobs. Whereas the Participation Act refers to acceptable work, respondents typically looked for work that matched their qualifications and/or interests. That is, they incorporated the idea of work that they had reason to value in their job search and were often less or not willing to take up work that did not fit their qualifications or interests, involved no challenge or did not contribute to a collective purpose. Working in a call centre was raised frequently as an example where the Social Services office's aim of moving people back into some kind of employment clashed with recipients' own views of valuable employment.

Application requirements and/or required registration at temporary employment agencies were a second point of tension. The crucial factor was that a link had to be made between these requirements, the individual situation, and trajectories towards the labour market. Failure to make sense of imposed constraints in relation to getting out of benefits was experienced as causing frustration, loss of control, and/or feelings of powerlessness: "Hence, they let people build up the frustration of a huge pile of letters where they either don't hear anything back or get a rejection. But you don't receive any feedback afterwards" (Peter, 45+). After one year with her application requirement, Lily (18-27) told her caseworker: "Everyday I write five applications and I don't find anything. How long do you still want me to continue searching? This is useless." Third, several respondents felt constrained in their strategies to get out by means of additional training, education or support with setting up their own businesses. These forms of active support were denied to them, typically because of budget constraints, as they were told. Some respondents reacted to this by seeking additional training without the support of the Social Services office.

\section{Participation placements and volunteering}

An arena in which many respondents depicted stories of active choices, initiative, and motivation was at their volunteer work or participation placement. Most interview partners who engaged in these activities were satisfied with them, yet had typically also actively worked to make them valuable by finding and/or shaping them by themselves. Recipients' motivations and the meaning they attached to these ac- 
tivities were at least twofold and centred around aspects of societal participation and contribution, and creating opportunities for personal development and/or employment. Joseph $(45+)$ explained that volunteering was a way for him to avoid social isolation and continue to be involved in society, but he equally used it to fill up gaps in his CV. Other narratives referred to being active rather than sitting alone at home, being useful, helping others and contributing to a collective purpose, as well as experiences of personal growth. It was in this context that some respondents described their strategy of always being one step ahead of the Social Services office, for instance by finding their own volunteer work instead of waiting to be assigned: "You can wait that the Social Services office guides you [emphasis] or you can do it by yourself. I have always simply initiated it by myself" (Linda, 45+). Hence, rather than waiting for activities being imposed on them, respondents kept in control by pre-empting the obligation to do something they maybe did not want to do.

Yet, the narratives also revealed the contested nature of participation placements as an instrument of active support to get out of benefits in the longer run, while equally being part of the code of conduct so that non-compliance could be sanctioned. Similar issues arose in regard to activities in return for benefits that are explicitly no reintegration instruments, yet may also not replace regular work places. Yet, where to draw the line appears to be a grey area. Several recipients felt that organisations took advantage of volunteers, or that volunteers did the same work as regular employees, but were only reimbursed differently. Greta (45+), for instance, said that she was considered as a temporary replacement for an employee on maternity leave. She strongly felt that it was wrong to let social assistance beneficiaries do regular work under the disguise of an activation policy. At the same time, she conceived that the rules and potential sanctions deprived her of the option to voice her concerns or exit the scheme, thus leaving her with the only option of loyalty (Hirschman, 1970). The role that sanctions played in constraining voice and exit options in this context, but also in relation to job search requirements, was raised by several respondents. They often also used the word 'punishment' instead of 'sanction' and depicted the communication as a sort of threat, made to people that do not 'behave': 'If you do not do that, we punish you.'

\section{Mediating agency at the Social Services office}

Throughout the majority of interviews, caseworkers were a crucial reference point. On the question of whether or not this relationship was important, most respondents 
answered the question in the affirmative. Caseworkers act as mediators between the written rules of the law and regulations and the lived experiences of recipients. It appeared that respondents' perceptions were partly linked to caseworkers' communication and here the extent to which the focus was more on elements of coercion or active support, as well as the degree to which structural constraints were taken into due consideration.

In that sense, negatively experienced interactions were characterised as hierarchical relationships in which respondents felt looked down upon, belittled, or judged, without attention paid to the individual recipient or sound consideration of the constraints within which she or he had to act - which, by themselves, could limit respondents in their actions, for instance in the case of physical or psychological health issues. Conflicts also emerged if respondents had an intended course of action or were motivated to find a job, yet perceived a lack of support or recognition by the caseworker in achieving this goal. Thomas, for instance, had devised a strategy to 'get out' of social assistance by setting up his own business, yet had the impression of being blocked by his caseworker. For him, these meetings felt like "talking to a brick wall", leaving him with a feeling of frustration: "I keep up my motivation, but it is just extremely difficult." Several respondents also commented on inherent power relations even if they had good relations with the caseworkers. They were well aware of the fact that the decisions taken by the caseworker could have a significant impact on their living situations, that it was in general more advantageous to be on good terms with the caseworker, or that you had to 'behave'.

In many other instances, however, the stories depicted elements of interactions that were experienced positively. These included caseworkers who were perceived as being approachable, empathetic and respectful, supportive and motivating. These caseworkers lead discussions on an equal footing, are unprejudiced and transparent and take into account the personal circumstances of each individual. Furthermore, the emphasis was on opening up perspectives in constructive ways and devising strategies together - hence elements of high active support in guidance. These aspects all spoke to the idea that recipients wanted to be recognised by caseworkers who took into account their past and options for the future, but also their present. Several respondents mentioned that they wanted caseworkers to see their strong motivation to find a job or their commitment at their volunteer or participation placement, and thereby recognise their agency in terms of getting out and getting by while living on benefits. 


\subsection{Discussion}

The qualitative findings shed light on the conditions under which different policy elements enhance or limit individuals' agency. The way in which agency is ultimately experienced depends on how the individual perceives the personal situation in relation to the labour market and the mediating role of activation workers, significant others and the society at large. Table 3.3 summarises the empirical links between activation and agency and qualifiers. These qualifiers as well as the mediators typically refer to the social fabric in which individuals are embedded and thereby emphasise the need to understand agency in relation to structural constraints and power relations. The interviews bring forcefully to the fore that the currently dominant model of the active welfare subject individualises the social. It neglects the importance of social structures that provide resources (or not) and reasons for particular behaviours (cf. M. L. Smith \& Seward, 2009). In that vein, the empirical analysis illustrates a discordance between a top-down conception of the welfare recipient as implied in the design and delivery of a number of elements of Dutch activation policy and a bottom-up view based on the lived experiences of social assistance recipients. The paradoxical result emerges that incentive-centred, coercive elements that aim to activate presumably passive individuals can contribute to growing feelings of frustration and, in the worst case, collapses of agency. The interviews showed that clashes between top-down and bottom-up views stem from two major sources. These are, first, the degree to which an individual's relative position in society is taken into account by policy design and implementation, as opposed to by the individual himself or herself. Second, the space, and some extent time, in which recipients' agency is evaluated by policymakers and/or policy implementers as opposed to by citizens.

First, individuals tell their narratives usually within a social context that encompasses the reasons for social assistance take-up beyond their personal control, the current labour market situation, and a broader web of interactions with significant others. Particularly in the context of the regional labour market in conjunction with the advanced age of many respondents, sometimes exacerbated by ill-health, respondents regularly felt that there was no demand for their participation in the workforce any longer. In a situation in which the capacity to act is already perceived as seriously constrained, the additional pressure induced by application requirements or obligations to be registered at a temporary employment agency can backfire. Instead of enhancing the capacity to act, the result at the individual level is a growing and sometimes even paralysing sense of frustration. 
Table 3.3: Links between Dutch activation policy, agency, qualifiers, and mediators

\begin{tabular}{|c|c|c|c|c|}
\hline $\begin{array}{l}\text { Dimension } \\
\text { of } \\
\text { activation }\end{array}$ & $\begin{array}{l}\text { Activation } \\
\text { policy } \\
\text { element }\end{array}$ & $\begin{array}{l}\text { Link to } \\
\text { agency }\end{array}$ & Qualifier & Mediator \\
\hline \multirow[t]{2}{*}{$\begin{array}{l}\text { Incentive } \\
\text { construc- } \\
\text { tion }\end{array}$} & $\begin{array}{l}\text { Income } \\
\text { replacement }\end{array}$ & $\begin{array}{l}\text { En- } \\
\text { hances/does } \\
\text { not limit } \\
\text { agency ... }\end{array}$ & $\begin{array}{l}\ldots \text {. if income } \\
\text { replacement is } \\
\text { perceived as } \\
\text { right/entitlement. }\end{array}$ & $\begin{array}{l}\text { Views of society } \\
\text { at large/ } \\
\text { significant } \\
\text { others/ } \\
\text { caseworker. }\end{array}$ \\
\hline & $\begin{array}{l}\text { Coercive } \\
\text { elements } \\
\text { · Definition } \\
\text { of } \\
\text { reasonable } \\
\text { job } \\
\text { - Code of } \\
\text { conduct } \\
\text { - Sanctions }\end{array}$ & $\begin{array}{l}\text { Limit } \\
\text { agency ... }\end{array}$ & $\begin{array}{l}\text {... if prescribed } \\
\text { behaviour is not } \\
\text { in line with own } \\
\text { efforts to find a } \\
\text { fitting (rather } \\
\text { than acceptable) } \\
\text { job, personal } \\
\text { circumstances } \\
\text { and/or } \\
\text { perceived labour } \\
\text { market } \\
\text { situation. }\end{array}$ & $\begin{array}{l}\text { Communication } \\
\text { and/or } \\
\text { discretion of } \\
\text { caseworker. }\end{array}$ \\
\hline \multirow[t]{2}{*}{$\begin{array}{l}\text { Active } \\
\text { support }\end{array}$} & High & $\begin{array}{l}\text { Enhances } \\
\text { agency ... }\end{array}$ & $\begin{array}{l}\ldots \text {.. if active } \\
\text { support and } \\
\text { case } \\
\text { management is } \\
\text { in line with own } \\
\text { preferences } \\
\text { and/or labour } \\
\text { market } \\
\text { situation. }\end{array}$ & $\begin{array}{l}\text { Communication } \\
\text { and/or } \\
\text { discretion of the } \\
\text { caseworker. }\end{array}$ \\
\hline & Low & $\begin{array}{l}\text { Limits } \\
\text { agency ... }\end{array}$ & $\begin{array}{l}\text {... if active } \\
\text { support is } \\
\text { perceived to be } \\
\text { needed with } \\
\text { regard to efforts } \\
\text { to find fitting } \\
\text { work, personal } \\
\text { circumstances } \\
\text { and/or } \\
\text { perceived labour } \\
\text { market } \\
\text { situation. }\end{array}$ & $\begin{array}{l}\text { Communication } \\
\text { and/or } \\
\text { discretion of the } \\
\text { caseworker. }\end{array}$ \\
\hline
\end{tabular}

Source: Author's own elaboration. 
A second mismatch emerges if recipients perceive that their actions to manage their daily lives or to devise strategies for their future do not fit the definition of expected actions by the Social Services office and are thus not recognised. In such a case, frustration and in the worst-case non-action is created rather than counteracted. This is in line with Whitworth (2016) who noted a similar mismatch in activation in the United Kingdom. Non-recognition of recipients' agency is not only an issue at the Social Services office, but it is also felt in interactions in which social assistance recipients are construed as free-riders or scroungers. As argued by Lister (2015), these are examples in which certain forms of agency are overlooked in welfare debates that are pre-occupied with holding individuals responsible for adverse life situations, rather than engaging in ways to encourage "self-creative responsibility" (Axelsen \& Nielsen, 2016, p. 1).

Nonetheless, in addition to such 'vicious cycles' that could be set off by negative interactions between loss of control and coercion, the narratives told frequently about 'virtuous cycles'. In these virtuous cycles, respondents felt that their motivation was recognised and their desire to develop was nurtured and actively supported. Activation activities such as participation placements or volunteer work could, for instance, achieve this. In this context, many respondents showed their ability and desire to make active choices and to shape their environments in meaningful ways. Caseworkers can function as important links who bridge gaps between individual experiences, external constraints and policy formulation and thereby successfully mediate agency in the course of activation policy implementation.

\subsection{Conclusion}

The start of this chapter posed questions on the links between different instruments of activation and agency, and the conditions under which social assistance recipients' agency is promoted or limited. For that purpose, it looked at an instrument-oriented, two-dimensional typology of activation policy. This typology puts particular focus on coercive welfare, that is, mixes rather than a dichotomy of demanding and enabling activation elements. Agency, in turn, was conceptualised on a continuum ranging from the self-as-object to the self-as-agent (Hoggett, 2001). This model accommodates the fact that individuals sometimes do not have the capacity to act, and at other times can shape their surroundings and act consciously. In the latter case, different forms of everyday and strategic agency were distinguished in line with Lister $(2004,2015)$. Based on literature on autonomy and choice, the argument was 
put forward that an individual's agency is enhanced the more a policy element or a combination of policy elements grant autonomy while offering high levels of active support.

Importantly, the study did not start from the assumption that individuals were inherently passive and needed to be activated. Rather, a research method was chosen that allowed individuals to report their lived experiences with regard to social assistance receipt and activation policy. By way of in-depth interviews, individuals compiled their own narratives and gave meaning to their experiences. Respondents' accounts provided an opposite pole to the current policy discourse in the Netherlands - the responsibility talk - and aligned remarkably well with currently emerging countercurrents of a number of Dutch policy implementers. The empirical analysis supported the conceptual links and substantiated the qualifying role of perceptions of an individual's situation in relation to the labour market, as well as the role of caseworkers and views of society at large. As discussed, clashes between a topdown and a bottom-up view of welfare recipients manifest in two ways. These are, first, the space (and time) that is taken into account when agency is expressed and acknowledged. The second clash emerges with respect to the extent to which individual situations are understood in relation to structural constraints.

The study illustrates the need to critically scrutinise underlying assumptions about human motivation and behaviour. Particularly in the context of policies that address individuals in socio-economically vulnerable situations, wrong assumptions do not only jeopardise a policy's effectiveness to reach intended goals. Of even graver concern is the way in which such assumptions run the risk of creating or reinforcing existing gaps in society, shaming individuals and attacking feelings of self-worth. Interestingly, over the last few years, a movement from the bottom meaning policy actors at the municipal level, often joining forces with academia - has emerged. It has voiced its critical view on different aspects of the Participation Act and the currently prevalent approach of inducing certain behaviours and punishing others. This movement manifests itself in a number of experiments that are currently being conducted in different municipalities across the Netherlands. This is different from the Finnish basic income experiment that was rolled out at the national level (De Wispelaere, Halmetoja, \& Pulkka, 2018). One aspect that all Dutch experiments have in common is that they embrace a different view on human motivation. They aim to compare, for instance, the benefits of a less coercive approach, more offers of additional support, or the possibility to earn income on top of the benefit up to a certain threshold (e.g. Gemeente Utrecht, 2019). 
These initiatives clearly contradict the policy trends that have been witnessed over the past decades, described as a move from a logic of social protection towards a logic of self-responsibility (Sol et al., 2008), or the "new model of responsibility" (Vrooman et al., 2012, p. 19). Often inspired by behavioural sciences as well as discourses on basic income or social citizenship, these developments have been referred to as an emerging policy paradigm (Groot et al., 2019) that has not yet been implemented in actual policymaking. The present chapter can be located within this movement. This background lends additional significance to the research, as this chapter provides new empirical evidence on why the current approach to social assistance and activation should be rethought. Yet, the question to what extent these insights will resonate at the top, that is, with national policymakers, still needs to be answered. 


\section{References}

Aurich, P. (2011). Activating the unemployed - Directions and divisions in Europe. European Journal of Social Security, 13(3), 294-316.

Axelsen, D. V., \& Nielsen, L. (2016, September). Being responsible and holding responsible: Why we should care about the former, but not the latter. Conference paper.

Bonoli, G. (2010). The political economy of active labor-market policy. Politics 86 Society, 38(4), 435-457.

Bonoli, G. (2011). Active labour market policy in a changing economic context. In Regulating the risk of unemployment. National adaptions to post-industrial labour markets in Europe (p. 318-332). Oxford, United Kingdom: Oxford University Press.

Braun, V., \& Clarke, V. (2006). Using thematic analysis in psychology. Qualitative Research in Psychology, 3(2), 77-101.

Burchardt, T., Evans, M., \& Holder, H. (2015). Public policy and inequalities of choice and autonomy. Social Policy \& Administration, 49(1), 44-67.

Burchardt, T., \& Holder, H. (2012). Developing survey measures of inequality of autonomy in the UK. Social Indicators Research, 106(1), 1-25.

Carter, E., \& Whitworth, A. (2016). Work activation regimes and well-being of unemployed people: Rhetoric, risk and reality of quasi-marketization in the UK work programme. Social Policy \& Administration, 51 (5), 796-816.

Centraal Bureau voor de Statistiek. (2019). StatLine. Retrieved January 3, 2019, from https://opendata.cbs.nl/statline/\#/CBS/nl/

Deacon, A. (2004). Different interpretations of agency within welfare debates. Social Policy and Society, 3(4), 447-455.

den Ridder, J., \& Dekker, P. (2012). De publiek opinie over eigen verantwoordelijkheid. In V. Veldheer, J.-J. Jonker, L. Van Noije, \& C. Vrooman (Eds.), Een beroep op de burger. Minder verzorgingsstaat, meer eigen verantwoordelijkheid? (pp. 277-302). The Hague, the Netherlands: Sociaal en Cultureel Planbureau.

De Wispelaere, J., Halmetoja, A., \& Pulkka, V.-V. (2018). The rise (and fall) of the basic income experiment in Finland. CESifo Forum, 19(3), 15-19.

Dingeldey, I. (2007). Between workfare and enablement - The different paths to transformation of the welfare state: A comparative analysis of activating labour market policies. European Journal of Political Research, 46(6), 823851. 
Dwyer, P. (1998). Conditional citizens? Welfare rights and responsibilities in the late 1990s. Critical Social Policy, 18(57), 493-517.

Eichhorst, W., Kaufmann, O., Konle-Seidl, R., \& Reinhard, H.-J. (2008). Bringing the jobless into work? An introduction to activation policies. In W. Eichhorst, O. Kaufmann, \& R. Konle-Seidl (Eds.), Bringing the jobless into work? Experiences with activation schemes in Europe and the US (pp. 1-16). Heidelberg, Germany: Springer.

Elshout, J. (2016). Roep om respect. Ervaringen van werklozen in een meritocratiserende samenleving (Unpublished doctoral dissertation). Amsterdam Institute for Social Science Research, Amsterdam, the Netherlands.

Esping-Andersen, G. (1990). The three worlds of welfare capitalism. Princeton, NJ: Princeton University Press.

Fryer, D. (1986). Employment deprivation and personal agency during unemployment: A critical discussion of Jahoda's explanation of the psychological effects of unemployment. Social Behaviour, 1, 3-23.

Gemeente Utrecht. (2019). Weten wat werkt: Samen werken aan een betere bijstand. Retrieved January 31, 2019, from https://www.utrecht.nl/werk-en -inkomen/weten-wat-werkt/

Government of the Netherlands. (2016a). Recht en hoogte uitkering (Participatiewet, informatie voor gemeenten). Retrieved June 29, 2016, from https://www.rijksoverheid.nl/onderwerpen/bijstand/ documenten/publicaties/2016/02/23/rechten-en-hoogte-uitkering

Government of the Netherlands. (2016b). Verplichtingen cliënten (Participatiewet, informatie voor gemeenten). Retrieved June 25, 2016, from https://www.rijksoverheid.nl/documenten/publicaties/2016/02/ 23/verplichtingen-clienten

Groot, L., Muffels, R., \& Verlaat, T. (2019). Welfare states' social investment strategies and the emergence of Dutch experiments on a minimum income guarantee. Social Policy \& Society, 18(2), 277-287.

Gubrium, E., \& Lødemel, I. (2014). (Relative) poverty in a rich, egalitarian welfare state. In E. Chase \& G. Bantebya-Kyomuhendo (Eds.), Poverty and shame: Global experiences (pp. 188-200). Oxford, United Kingdom: Oxford University Press.

Hirschman, A. O. (1970). Exit, voice, and loyalty: Responses to decline in firms, organizations, and states. Cambridge, MA: Harvard University Press.

Hoggett, P. (2001). Agency, rationality and social policy. Journal of Social Policy, $30(1), 37-56$. 
Jahoda, M. (1982). Employment and unemployment: A social-psychological analysis. Cambridge, United Kingdom: Cambridge University Press.

Kampen, T. (2014). Verplicht vrijwilligerswerk: De ervaringen van bijstandscliënten met een tegenprestatie voor hun uitkering (Unpublished doctoral dissertation). University of Amsterdam, Amsterdam, the Netherlands.

Kampen, T., Elshout, J., \& Tonkens, E. (2013). The fragility of self-respect: Emotional labour of workfare volunteering. Social Policy and Society, 12(3), 427438.

Kampen, T., \& Tonkens, E. (2019). Empowerment and disempowerment of workfare volunteers: A diachronic approach to activation policy in the Netherlands. Social Policy and Society, 18(3), 351-364.

Knotz, C. M. (2019). Why countries 'get tough on the work-shy': The role of adverse economic conditions. Journal of Social Policy, 48(3), 615-634.

Kremer, M., van de Meer, J., \& Ham, M. (2017). Werkt de zachte hand in de bijstand? Tijdschrift voor Sociale Vraagstukken, Winter 2017(4), 14-19.

Lister, R. (2004). Poverty. Cambridge, United Kingdom: Polity.

Lister, R. (2015). 'To count for nothing': Poverty beyond the statistics. Journal of the British Academy, 3, 139-165.

Lødemel, I., \& Moreira, A. (2014). Introduction. In I. Lødemel \& A. Moreira (Eds.), Activation or workfare? Governance and the neo-liberal convergence (p. 1-18). Oxford, United Kingdom: Oxford University Press.

Marchal, S., \& Mechelen, N. (2017). A new kid in town? Active inclusion elements in European minimum income schemes. Social Policy \& Administration, 51(1), 171-194.

McIntosh, I., \& Wright, S. (2019). Exploring what the notion of 'lived experience' offers for social policy analysis. Journal of Social Policy, 48(3), 449-476.

Mead, L. M. (1992). The new politics of poverty: The nonworking poor in America. New York, NY: BasicBooks.

Molander, A., \& Torsvik, G. (2015). Getting people into work: What (if anything) can justify mandatory activation of welfare recipients? Journal of Applied Philosophy, 373-392.

Murray, C. A. (1984). Losing ground: American social policy, 1950-1980. New York, NY: BasicBooks.

Noël, A. (2019). The politics of minimum income protection in OECD countries. Journal of Social Policy, 48(2), 227-247.

Ohls, C. (2017). A qualitative study exploring matters of ill-being and well-being in Norwegian activation policy. Social Policy and Society, 16(4), 593-606. 
Organisation for Economic Co-operation and Development. (2018, May). Data. Retrieved May 8, 2018, from https://data.oecd.org/

Patrick, R. (2014). Working on welfare: Findings from a qualitative longitudinal study into the lived experiences of welfare reform in the UK. Journal of Social Policy, 43(4), 705-725.

Patrick, R. (2017). For whose benefit? The everyday realities of welfare reform. Bristol, United Kingdom: Policy Press.

Peeters, R. (2013). Responsibilisation on government's terms: New welfare and the governance of responsibility and solidarity. Social Policy 85 Society, 12(4), $583-595$.

Peeters, R., \& Drosterij, G. (2011). Verantwoordelijke vrijheid: Responsabilisering van burgers op voorwaarden van de staat. Beleid en Maatschappij, 38(2), 179-189.

Pellissery, S., Lødemel, I., \& Gubrium, E. K. (2014). Shame and shaming in policy processes. In E. Gubrium, S. Pellissery, \& I. Lødemel (Eds.), The shame of it: Global perspectives on anti-poverty policies (pp. 179-198). Bristol, United Kingdom: Policy Press.

Sirovátka, T., \& Sol, E. (2013). Multiple barriers and bridges to work. Universiteit van Amsterdam, AIAS Working Paper, 138.

Smith, D. E. (1987). The everyday world as problematic: A feminist sociology. Boston, MA: Northeastern University Press.

Smith, M. L., \& Seward, C. (2009). The relational ontology of Amartya Sen's capability approach: Incorporating social and individual causes. Journal of Human Development and Capabilities, 10 (2), 213-235.

Sol, E., Sichert, M., van Lieshout, H., \& Koning, T. (2008). Activation as a socioeconomic and legal concept: Laboratorium the Netherlands. In W. Eichhorst, O. Kaufmann, \& R. Konle-Seidl (Eds.), Bringing the jobless into work? Experiences with activation schemes in Europe and the US (pp. 161-220). Heidelberg, Germany: Springer.

Spies, H., \& van de Vrie, N. (2014). From legitimacy to effectiveness. Developments in activation in the Netherlands. In I. Lødemel \& A. Moreira (Eds.), Activation or workfare? Governance and the neo-liberal convergence (pp. 143-171). Oxford, United Kingdom: Oxford University Press.

van Berkel, R. (2007). Social assistance dynamics in the Netherlands: Exploring the sustainability of independence from social assistance via labour market inclusion. Social Policy and Society, 6(2), 127-139.

van Berkel, R. (2010). The provision of income protection and activation services 
for the unemployed in 'active' welfare states. An international comparison. Journal of Social Policy, 39(1), 17-34.

van Echelt, P., \& Josten, E. (2012). Werken voor je geld. In V. Veldheer, J.J. Jonker, L. Van Noije, \& C. Vrooman (Eds.), Een beroep op de burger. Minder verzorgingsstaat, meer eigen verantwoordelijkheid? (pp. 95-115). The Hague, the Netherlands: Sociaal en Cultureel Planbureau.

Veldheer, V., Jonker, J.-J., Van Noije, L., \& Vrooman, C. (Eds.). (2012). Een beroep op de burger. Minder verzorgingsstaat, meer eigen verantwoordelijkheid? The Hague, the Netherlands: Sociaal en Cultureel Planbureau.

Verhoeven, I., \& Tonkens, E. (2013). Talking active citizenship: Framing welfare state reform in England and the Netherlands. Social Policy and Society, 12(3), 415-426.

Vrooman, C., Van Noije, L., \& Veldheer, V. (2012). Responsable burgers, regisserende overheid. In V. Veldheer, J.-J. Jonker, L. Van Noije, \& C. Vrooman (Eds.), Een beroep op de burger. Minder verzorgingsstaat, meer eigen verantwoordelijkheid? (pp. 11-31). The Hague, the Netherlands: Sociaal en Cultureel Planbureau.

Walker, R., Kyomuhendo, G. B., Chase, E., Choudhry, S., Gubrium, E. K., Nicola, J. Y., ... others (2013). Poverty in global perspective: Is shame a common denominator? Journal of Social Policy, 42(2), 215-233.

Whitworth, A. (2016). Neoliberal paternalism and paradoxical subjects: Confusion and contradiction in UK activation policy. Critical Social Policy, 36(3), 412431.

Wright, S. (2012). Welfare-to-work, agency and personal responsibility. Journal of Social Policy, 41(2), 309-328.

Wright, S. (2016). Conceptualising the active welfare subject: Welfare reform in discourse, policy and lived experience. Policy \& Politics, 44 (2), 235-252. 



\section{Sustaining the Integrity of the Threatened Self of Social Assistance Recipients:}

A Clustered Randomised Trial

\subsection{Introduction}

Recent welfare reforms have emphasised the idea of the increased individual responsibility of beneficiaries vis-à-vis the state. ${ }^{1}$ In 2014, the Dutch government passed the Participation Act that aims to increase labour participation, including for groups that face physical or psychological constraints. While such reforms are framed as appealing from the perspective of providing for a more inclusive labour force, a more cynical view is that they are linked to an increasing public perception that welfare subjects are deficient or passive (Wright, 2016). Indeed, stereotyping and stigmatising terms such as welfare dependency and underclass or categories of moral worth such as the undeserving poor feature prominently in many societies across the world (cf. Lister, 2004, 2015). The threat of being judged or treated negatively in light of stereotypes is a situational predicament that is termed "stereotype threat" (Spencer, Fein, \& Lomore, 2001, p. 415). Members of stigmatised groups feel at risk that their behaviours are assessed against the backdrop of these stereotypes. This can induce a disruptive state hampering performance and undermining aspirations. Conceptually, welfare recipients may be perceived socially as having low levels of competence, low status, and a lack of warmth. This feeds into perceptions of them as opportunistic free-riders who compete for and exploit scarce societal resources (Fiske, Cuddy, Glick, \& Xu, 2002). Such perceptions may elicit emotions of contempt and disgust against this group, which may result in harmful behaviour against them that could be active (harassment) and/or passive (neglect, exclusion) (Cuddy, Fiske, \& Glick, 2007).

1 I would like to thank all participants, caseworkers and Maastricht Heuvelland Social Services for their cooperation, and the administrative and financial support provided. Comments on earlier versions of this chapter were provided by Franziska Gassmann, Lonneke Nillesen and Fred Zijlstra. 
Empirical investigations into stigma among welfare recipients goes back at least as far as Handler and Hollingsworth (1969) who surveyed recipients of the Aid to Families with Dependent Children in six counties in the US state of Wisconsin. They found that about half of their sample experienced feelings of stigma and those who felt stigmatised were less satisfied with the programme and were on average less satisfied with their caseworker. While people who felt stigmatised were not more likely to leave the programme, among those who did leave, stigmatised respondents were more likely to leave through their own efforts, either by getting a job or through a change in their marital status. The authors interpreted this as those people behaving in an extremely socially desirable way because of feelings of shame. This study, however, merely described patterns in the data rather than providing firm evidence on the impacts of stigma among welfare recipients and how to mitigate this. More recent studies, for instance in the United Kingdom, Norway, and the Netherlands, found qualitative evidence of beneficiaries' experiences with the stigma of receiving benefits (Garthwaite, 2016; Gubrium \& Lødemel, 2014; Kampen, 2014; Lister, 2004, 2015; Ohls, 2017; Patrick, 2016, 2017), There are also several quantitative studies looking into this issue (Baumberg, 2016; Bertrand, Luttmer, \& Mullainathan, 2000; Lee \& Oguzoglu, 2007). Furthermore, there is some evidence of non-take-up, that is, people who refrain from using or applying for social benefits for which they are eligible due to (fear of) being stigmatised, alongside other more traditional factors that may explain low take-up including transaction costs and lack of information (Currie, 2006; Currie \& Grogger, 2001; Moffitt et al., 1983).

However, living on a low income and welfare receipt is associated with many more socio-economic and psychological consequences than stigma alone. Indeed, scarce resources, stress, and low social standing are also likely to play a role. Over the past decades, evidence has accumulated that these conditions are associated with distinct patterns of how individuals think, behave, or navigate their lives (e.g. Gennetian \& Shafir, 2015; Haushofer \& Fehr, 2014; Shafir, 2017; Sheehy-Skeffington \& Rea, 2017). A systematic review by Sheehy-Skeffington and Rea (2017) concluded that living on a low income was associated with lower feelings of self-worth, less favourable perceptions of self-efficacy, avoidance-based behaviour, a lower sense of societal belonging and withdrawal from public activities (see also Kunze \& Suppa, 2017). Living on a low income may not only seriously affect well-being through the psychological and relational aspects of reduced feelings of self-worth and social inclusion but may also lead to biased information processing, reduced cognitive performance and low self-efficacy beliefs that inhibit activities such as job search efforts. 
Previous studies have demonstrated the potential of so-called self-affirmation interventions - that is, interventions that expand the view of the "self" - to curb these adverse psychological effects (Cohen \& Sherman, 2014; Hall, Zhao, \& Shafir, 2014). Yet, the interventions described in Cohen and Sherman (2014) all fall within the domains of education, health, intergroup conflict or interpersonal relationships. Only the study by Hall et al. (2014) focused on low-income individuals using randomised field experiments at an inner-city soup kitchen in New Jersey. The authors found positive impacts of self-affirmation on fluid intelligence and openness to information related to social assistance benefits. This study is the most closely linked to what we do in our research.

We build on Hall et al. (2014) in a number of ways. First, we test the effectiveness of a randomised self-affirmation intervention on people who are unemployed, live on a low income, and are in the process of applying for social assistance benefits. This enables us to link the literature on the adverse psychological and behavioural impacts of living on welfare benefits to that on evidence of self-affirmation interventions. We hypothesise that a self-affirmation intervention among our population may strengthen a potential recipient's sense of self-worth, reduce stress levels, promote positive perceptions of job search-related self-efficacy and cognitive performance, and foster feelings of societal belonging. Obtaining such insights is important for policymakers as low-cost and possibly effective self-affirmative interventions may provide a promising complement to more expensive and complex interventions to improve socio-economic outcomes of people living on low incomes and social assistance. Second, our study is executed in a setting where the potential impact of the stereotype threat is particularly high: a Social Services office where applicants for social assistance have to physically come and meet with caseworkers. A visit to the Social Services office is arguably a situational cue that triggers the stereotype threat. Third, we use an extensive set of potential outcomes, including outcomes related to job search self-efficacy.

We find that there is no average effect of self-affirmation on our main outcomes, except for a negative impact on societal belonging that runs counter to our expectations. Yet, average treatment effects may gloss over important heterogenous impacts, as certain groups may differentially benefit from the same intervention. Indeed, our subgroup analyses reveal a number of distinct and interesting results. First, and also contrary to our expectations, treatment causes a 0.3 to 0.5 standard deviations increase in negative feelings of self-worth among those who had a paid job in the past two years. Also, treatment reduces feelings of societal belonging 
especially among those with a higher education. By contrast, treatment increases job search self-efficacy by about 0.5 standard deviations among respondents with lower levels of education. Our results are consistent across various model specifications and support the idea that the self-affirmation exercise as undertaken in our study might be beneficial especially for people that face increased challenges to (re)integrate into the labour market due to low education levels, having had social assistance benefits in the past two years and not having had paid work in the same period. At the same time, such self-affirmation may induce backlash effects on those who have better labour market perspectives.

Although we are unable to say how long potential impacts remain and whether such interventions indeed help increase the likelihood of leaving the social assistance scheme, and thus in the end affect labour market outcomes, our study provides important evidence on immediate outcomes that are plausibly conducive to longterm impacts, including finding qualified work. The chapter proceeds as follows. In Section 4.2 we describe the conceptual framework that details how self-affirmation can "work" in the context of welfare and activation and discuss relevant literature; Section 4.3 describes the context and the intervention; Section 4.4 presents the empirical strategy and the results; Section 4.5 comprises a discussion of the results and Section 4.6 set out our conclusions.

\subsection{Related Literature}

The basic premise of self-affirmation theory is that individuals have an innate need for maintaining the integrity and worth of the self. The self system comprises different domains, including roles, for example as student or employee; values, such as religion; group identities based on race or nation; central beliefs, such as political beliefs; goals, for example academic achievements or achievements at work; and relationships (Sherman \& Cohen, 2006). A psychological threat occurs when a person perceives that the environment challenges her self-integrity. For instance, job loss can threaten someone's role as a valued employee or reliable breadwinner. A psychological threat sets in motion a number of interrelated mechanisms (Schmader, Johns, \& Forbes, 2008): (1) a physiological stress response, (2) suppression processes in order to avoid negative thoughts and emotions, and (3) increased monitoring processes of the environment in relation to oneself. Together, these three mechanisms consume mental resources, with the increased cognitive load having negative repercussions on working memory, cognitive performance and problem-solving abilities. 
However, the self system is also flexible and can cope with a psychological threat in one domain by affirming oneself in another domain in a fungible way. Selfaffirmations are acts that demonstrate an individual's continued adequacy in face of a threat and enable a more holistic perspective of the self. This expanded view of the self also means that the threat impacts less on psychological well-being ("turns down the inner alarm of psychological threat", as Cohen and Sherman (2014, p. 354) said) and therefore buffers against stress and curbs self-protective defences. Finally, affirmations promote a different way of coping with threats and foster an approach orientation rather than avoidance. Self-affirmation tasks have been operationalized in various ways in experimental studies. Methods differ in terms of affirmation domain (specific value or personal characteristic), attainment of this value or characteristic (provided by the researcher or chosen by the respondent), and procedure (respond to a scale, write an essay, or imaginary techniques) (cf. McQueen \& Klein, 2006). A typical manipulation aks participants to rank a list of personal characteristics, values, or skills. Subsequently, participants are asked to write a brief essay in which they explain why the top-ranked value or characteristic is important to them. Participants in the non-affirmed condition are asked to reflect on a mediumor bottom-ranking value or characteristic (for instance Critcher \& Dunning, 2015; Schmeichel \& Vohs, 2009). Importantly, the affirmation needs to be unrelated to the domain of threat, as affirmations related to the threatening event or domain may backfire (Sherman \& Cohen, 2006). In general, self-affirmation lifts barriers to change and adaptation (Cohen \& Sherman, 2014). In order to understand more precisely the workings of affirmations and the effects they can deliver in our context of a Social Services office, the following paragraphs review the empirical literature on the way in which self-affirmations may impact on sense of self-worth, stress, societal belonging, self-efficacy, and cognitive performance.

First, job loss and the subsequent necessity to apply for social assistance benefits can lead to feelings of shame, humiliation, inadequacy, or being a failure (see also Chapter 2 and Chapter 3). An individual's sense of self-worth may be severely damaged by being deprived of this defining domain in one's self system. Reducing the negative implications of this psychological threat should not only be a means to lift barriers to change and adaptation, but also a goal in itself within welfare systems that are concerned with individual well-being in a broader sense. According to Critcher and Dunning's (2015) 'affirmation as perspective' model, the damaged identity may dominate one's self-concept and narrow the scope towards the threatened domain, thereby letting it loom disproportionately large. As a result, self-evaluations are more contingent on the threatened domain than on a larger concept of the self. 
Affirmations remind individuals of other domains that define them and in this way put the threat into a broader perspective. Second, some studies concluded that self-affirmation reduced physiological and psychological stress (Creswell et al., 2005; Sherman, Bunyan, Creswell, \& Jaremka, 2009). Another example was a writing exercise among breast cancer survivors. Participants who included self-affirmative messages in their essays experienced lower levels of distress, which indicated the stress-buffering effect of the self-affirmation (Creswell et al., 2007).

Third, it is conceivable that self-affirmation reduces feelings of social exclusion by buttressing a person's self-integrity (Cook, Purdie-Vaughns, Garcia, \& Cohen, 2012; Critcher \& Dunning, 2015, e.g.). A previous study tested this hypothesis in the context of a middle school and showed that self-affirmation stabilised African American students' sense of belonging (Cook et al., 2012). Fourth, several studies have explored the effects of values affirmation on self-efficacy. Perceived self-efficacy refers to "people's beliefs about their capabilities to produce designated levels of performance that exercise influence over events that affect their lives" (Bandura, 1994, p. 71). Self-efficacy is a prominent variable in the job search literature. It is a building block of social cognitive theory, self-regulation theory, the theory of planned behaviour, or expectancy value theory that are frequently cited in this context (Bandura, 1994; Kanfer \& Bufton, 2015; Kanfer, Wanberg, \& Kantrowitz, 2001; Liu, Huang, \& Wang, 2014; Saks, Zikic, \& Koen, 2015). In a meta-analysis of 60 studies, Liu et al. (2014) concluded that job search interventions that included an element to bolster self-efficacy (such as enactive mastery of job search behaviours or verbal self-guidance) increased the odds of obtaining employment considerably.

There are a number of studies that show the positive effects of self-affirmation on self-efficacy, for instance in the context of caffeine intake (Reed \& Aspinwall, 1998), healthy eating (Epton \& Harris, 2008), or anti-smoking messages (Zhao \& Nan, 2010). Affirmed participants had stronger beliefs in their abilities to adjust their behaviours in health-promoting ways; on average, outcome measures were at least half a standard deviation higher than in the control group. Such studies are typically based on the assumption that self-affirmation facilitates systematic and balanced processing of information, that affirmed participants are more open to information, and that they assess information and the role of the context and themselves more honestly. Another route could be that self-affirmation contributes to reducing stress, which, in turn, could enhance self-efficacy (cf. Epton \& Harris, 2008). Finally, it is conceivable that self-affirmation increases one's self-regard and perceptions of ability and control, thereby also elevating perceptions of self-efficacy 
(Zhao \& Nan, 2010). Yet, reducing caffeine intake or eating healthily are both outcomes that are plausibly fully controlled by individuals themselves. This is different from job search self-efficacy. Saks et al. (2015) argued that measures of job search self-efficacy should distinguish between job search behaviours and job search outcomes. Whereas job search behaviours are primarily controlled by the jobseeker, job search outcomes are the result of a multitude of interrelated factors, for instance educational attainment, profession, age, and the labour market situation. Hence, if self-affirmation allows for a more honest assessment of one's circumstances and one's own contributions, then it can be expected that self-affirmation enhances job search behaviour self-efficacy. In contrast, the effect is ambiguous regarding job search outcome efficacy, where less biased processing of information could lead to more positive or negative assessments depending on the individual situation in relation to the job market. Furthermore, Vohs, Park, and Schmeichel (2013) illustrated that the positive effect of self-affirmation on self-efficacy might be reversed if people immediately afterwards failed in a task. This suggests that "success" of self-affirmation exercises are dependent on timing and context.

Finally, self-affirmation has been shown to enhance cognitive performance. Particularly in the domain of education, evidence suggests that self-affirmative interventions reduce achievement gaps based on race or sex (e.g. Cohen, Garcia, PurdieVaughns, Apfel, \& Brzustoski, 2009; Martens, Johns, Greenberg, \& Schimel, 2006; Miyake et al., 2010; Walton \& Spencer, 2009). Miyake et al. (2010), for instance, tested a values affirmation in a college-level introductory physics class. Two brief writing exercises (10 to 15 minutes) over a 15-week course increased women's modal grade from the $\mathrm{C}$ to the $\mathrm{B}$ range and thereby reduced the gender achievement gap considerably. In particular, women who believed that men do better on physics than women profited most strongly from the affirmation. Sheehy-Skeffington and colleagues (cited in Sheehy-Skeffington and Rea (2017, p. 17)) designed a study in which socio-economic status was experimentally manipulated. Those participants who believed that they were low on socio-economic status performed worse on a measure of executive function. This group equally performed worse on a complex decision-making task. The authors interpreted these findings as indicating that status threat distracted from the task at hand. Other research has indicated that selfaffirmation enhances problem-solving among chronically stressed individuals with impaired problem-solving capacity (Creswell, Dutcher, Klein, Harris, \& Levine, 2013). Conceptualising welfare stigma as stereotype threat, Hall et al. (2014) found that self-affirmation had positive effects on cognitive performance (using Raven's Standard Matrices) among participants recruited at an urban soup kitchen. This 
study is remarkable, as it used a newly developed oral affirmation, which is particularly easy to implement in terms of time and cost, as well as across different settings. For participants in the affirmed condition, the increase in cognitive performance was comparable to the difference in performance between an average 55-year-old and 45year-old. The same study also demonstrated that an oral affirmation could increase openness to potential threatening information, echoing results from health-related studies. Affirmed participants were more likely to stop at a table where fliers on Earned Income Tax Credits and Volunteer Income Tax Assistance were offered, and to take a flier.

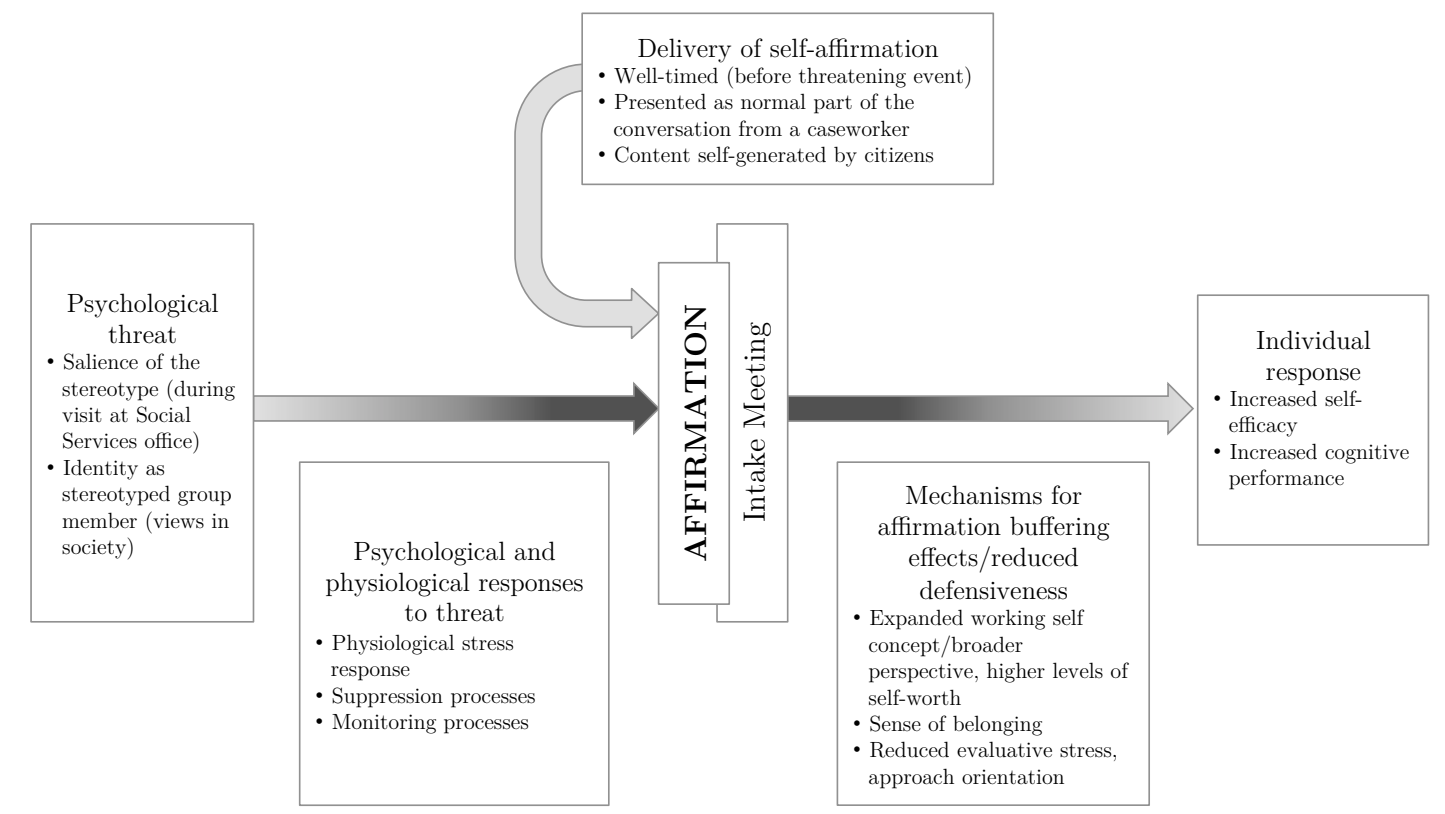

Figure 4.1: Framework for studying self-affirmation in the context of welfare and activation

Source: Adapted illustration of Borman (2017, p. 7487), based on Cohen and Sherman (2014); Schmader et al. (2008); Sherman (2013).

Figure 4.1 summarises the main mechanisms and results presented in the reviewed literature. The delivery of the self-affirmation exercise and a detailed description of the context in which it was carried out follows in Section 4.3. We test the following hypotheses:

Participants in the self-affirmed condition ...

(H1) ... have higher feelings of self-worth;

(H2) ... report lower levels of stress;

(H3) ... report higher levels of societal belonging; 
(H4) ... have more favourable perceptions of self-efficacy related to job search behaviour; and

(H5) ... show better cognitive performance ...

... than participants in the non-affirmed condition.

\subsection{Context and Intervention}

The experiment was conducted between October 2017 and December 2018 in the Social Services office of the city of Maastricht, the Netherlands. ${ }^{2}$ In 2017, the unemployment rate in Maastricht was 5.6 per cent, and 4.7 per cent in the province of Limburg, which is roughly equal to the national rate in the same year. The proportion of social assistance recipients in the municipality (47 social assistance recipients per 1,000 inhabitants aged 15 to 65) is comparable to other municipalities in the Netherlands with more than 100,000 inhabitants. The regional labour market has undergone structural changes in recent decades, evolving away from the manufacturing towards the service industry. The Social Services office of Maastricht is part of the regional collaboration Maastricht Heuvelland in which six municipalities joined forces to implement the Participation Act (Maastricht-Heuvelland, 2014) which is the legal framework for governing means-tested social assistance benefits in the Netherlands since 2015.

Applications for social assistance have to be submitted electronically. Within two working days after submission, individuals have to appear in person at the Social Services office with a valid ID card for a short eligibility screening. The subsequent process depends on the applicant's age. For applicants older than 27 years, a so-called intake meeting is planned immediately. In contrast, applicants aged 18 to 27 have a compulsory job search period of four weeks during which they have to document their job search efforts before they have their intake meeting. Furthermore, some of these applications (based on the region) are processed by a caseworker of a separate team (team youth). Finally, meetings with applicants who are currently in the naturalisation process are conducted by two specialised employees. All other applicants meet a caseworker of the regular intake team. Some of these caseworkers were part of a project team that investigated the extent to which the process of screening and intake meeting could be streamlined. This means

2 All figures in this section are retrieved from Statistics Netherlands (Centraal Bureau voor de Statistiek, 2019). 
that for some applicants, the screening and intake meetings were combined. In all cases, the allocation of applicants to caseworkers is solely based on the caseworkers' availability. Characteristics beyond the applicants' age are not taken into account.

During the intake meeting, applicants have to provide all documents that are necessary to check benefit eligibility. In addition, they are informed about their rights and obligations as social assistance recipients, including job search requirements. Finally, individuals are often directly transferred to a workplace (transferium) for the following thirteen weeks. If individuals have not found work by the end of this process, they receive the status of an active file and are directed to a new caseworker in the team who manages these active files. On the basis of a diagnosis that has been prepared at the workplace (transferium), possible additional (competence) tests and their own assessment, caseworkers in this team decide on the type of reintegration activities and obligations that they judge as suitable. Meetings or phone calls are also conducted as caseworkers see fit.

In line with the intervention logic, we decided to focus on individuals' intake meetings at the Social Services office. Previous research has stressed that the affirmation's effectiveness crucially depends on its timing. A well-timed and appropriately situated intervention can be a turning point in a process that sets off positive, mutually reinforcing feedback loops between the self system and the social system (Cohen \& Sherman, 2014). It is therefore appropriate to conduct the self-affirmation as early as possible in the context of the Social Services office as a potentially threatening context. Whereas the initial screening is a short procedure with a gate-keeping function, the intake meeting usually lasts approximately one hour. As one of the aims is to get to know the applicant, the affirmation can be included in a meaningful way in these meetings. Furthermore, it is particularly during this meeting that focuses on rights, obligations, and job search, that applicants are arguably most in need of an affirmation that may positively impact on openness to information, unbiased information processing, and self-efficacy.

Our aim was to develop an affirmation that could easily be included in standard work processes and that could be implemented by caseworkers themselves. The verbal affirmation procedure that was used in this study was developed based on the verbal affirmation ${ }^{3}$ presented by literature on self-affirmation in general (e.g.

3 At the design stage, to the best of our knowledge there had been no further published studies that used a verbal affirmation in a comparable way. However, verbal self-affirmation in the context of poverty has been explored by other authors as well (e.g. Banker, Bhanot, \& Deshpande, 2018; Weiss, Rockenbach, Schneiders, \& Vollan, 2017). 
Cohen \& Sherman, 2014; McQueen \& Klein, 2006) and that of Hall et al. (2014) specifically, as well as principles of motivational interviewing (cf. Ehret, LaBrie, Santerre, \& Sherman, 2015). We developed a protocol that stipulated that: (i) the caseworker should seek citizens' permission to talk about personal values; (ii) the affirmation should be conducted at the beginning of the meeting; (iii) the self should be affirmed in a domain chosen by the participant that is outside the threat; and (iv) the affirmation should be introduced in descriptive and not in psychological terms. Caseworkers read out the following text to respondents in the treatment group:

As you know, the aims of this meeting are to [explain the objectives of the meeting]. But before we start with these topics, I would like to get an idea of who you are and what is important for you - not related to work, but to you as a person. Is that okay?

[Participant answers. If he or she does not agree, the self-affirmation is not implemented.]

Can you describe to me an experience or event that made feel you successful or proud?

[Participant answers. If necessary, it is possible to give examples. For example: Some people tell about values they find important, for instance their religion. For others, certain activities or hobbies are important or they are proud of personal characteristics. Or they talk about relationships, for instance with their family or friends.]

Can you explain why that made you feel proud/why that felt good?

[Participant answers.]

Participants in the non-affirmed (control) condition were asked neutral introductory questions, for example about the mode of transport they used to get to the Social Services office.

The self-affirmation exercise was pre-tested with two caseworkers, one from the regular intake team and one from the team youth. All caseworkers who were eligible for the study (see below) were trained in a two-hour workshop that included a presentation on the intervention logic and hypotheses, as well as a training session in groups. 


\subsection{Research Method}

In this section, we firstly justify the use of a clustered randomised trial. Subsequently, we provide details on sample size calculations, randomisation, and participants and describe the analytical strategy.

\subsubsection{Randomised Clustered Trial}

The hypotheses are tested in a clustered randomised trial with one treatment and one control arm. Caseworkers represent the clusters in which the applicants with whom they conduct the intake meeting are naturally grouped. As outlined above, social assistance applicants are in essence randomly assigned to caseworkers in line with organisational work processes. Randomisation at the cluster level (the caseworkers) was preferred over randomisation at the individual level (the social assistance applicants) after weighing the trade-offs between statistical efficiency and the research setting (Donner \& Klar, 2004; Hayes \& Moulton, 2009; Wears, 2002).

On the one hand, randomisation by cluster is costly as statistical efficiency is lost. Individuals within clusters (clusters in other studies are typically patients in hospitals; students in classrooms/schools; or people within a community) tend to be more similar than individuals across clusters. The degree to which this is the case is quantified by the intracluster correlation coefficient (ICC) $\rho . \rho$ is defined as the share of between-cluster variance $\sigma_{B}^{2}$ in the overall variance $\sigma^{2}$ (the sum of between- and within-cluster variance $\sigma_{B}^{2}$ and $\sigma_{W}^{2}$ ). Three main reasons for withincluster correlation are clustering of population characteristics, variations in response to intervention, and correlation due to interaction between individuals (Hayes \& Moulton, 2009). The first source, clustering of population characteristics, is unlikely to play a role in the setting at the Social Services office. As described above, with the exception of age, new applicants are not systematically allocated to caseworkers. Except for age, it is unlikely that applicants' characteristics differ systematically across caseworkers. Equally, the third source, interactions among individuals, is unproblematic in the research setting. Since the outcome variables are measured directly after the meeting, it is unlikely that applicants who fill in the survey interact with other applicants who had or who are going to have a meeting with the same caseworker.

Variations in response to the intervention are, however, a likely source of within- 
cluster correlation. Different characteristics of caseworkers may be responsible for variations in response to the self-affirmation across clusters. Possible distinguishing features that may interact with the intervention are a caseworker's general understanding of and approach to his or her work (e.g. more emphasis on rule implementation and fraud detection vs. relatively more focus on supporting services or motivation). ${ }^{4}$ Caseworkers may also differ in their openness and commitment to experimenting with new methods and learning. Finally, skills, flexibility and "bandwidth" to conduct the self-affirmation as outlined in the protocol may vary.

A further complication arises from the fact that, due to the organisational structure, there were only 17 caseworkers who could be randomised into treatment and control conditions. Three of those caseworkers could not participate in the study due to changes in tasks and sick leave. In the course of the experiment, one employee left the office and three new colleagues joined the youth team. With few cases, randomisation might not ensure adequate balance between caseworkers in the treatment and control condition (Hayes \& Moulton, 2009; Torgerson, 2001, pp. 39-40). The possibility that caseworkers are on average not similar regarding potentially confounding factors enhances the concern that applicants' responses may to some extent vary depending on who implements the treatment. Finally, the small number of clusters complicates data analysis beyond the fact that clustering needs to be taken into account. However, models for clustered data with very few clusters have recently attracted more attention and several options are available (e.g. McNeish \& Stapleton, 2016b).

On the other hand, considerations of the research setting strongly suggested a cluster randomised trial. The intervention is based on a training for caseworkers to include a small number of additional questions at the beginning of the meeting. It is therefore aimed at the practice of a professional (Hutton, 2001). Even though the additional questions to be asked are very clearly stated and the changes to the overall way of conducting a meeting are limited in scope, one may wonder whether caseworkers can easily switch between different conditions in practice and intentionally or not mix up treatment and control conditions (Borm, Melis, Teerenstra, \& Peer, 2005; Duflo, Glennerster, \& Kremer, 2008). Glennerster (2014) and Karlan and Appel (2016) cautioned that researchers should not underestimate the mental effort and flexibility that it takes to implement even small changes with regard to familiar tasks and routines. Moreover, even if caseworkers are willing to deliver the

4 The extent to which caseworkers differ in their role understanding and what this means for citizens is discussed in Chapter 5. 
treatment and control condition as planned and ostensibly do so, it is possible that the way they conduct meetings in the control group are unconsciously influenced by experiences they made with the experimental group and the training in general (cf. Wears, 2002). Alternatively, caseworkers who have had positive experiences with the self-affirmation may feel that they would like to follow this approach in all meetings, regardless of an applicant's treatment status. Not being able to do so then may induce ethical concerns on the part of the caseworker.

On balance, we felt that the arguments related to the research setting weighed more heavily and opted for the cluster-level randomization. In the context of experimental studies on activation in welfare organisations, a cluster-randomised design has for instance also been favoured by Malmberg-Heimonen and Tøge (2016) or Behncke, Frölich, and Lechner (2009). We take the clustered nature of the data into account in both the sample size calculations and data analysis.

\subsubsection{Sample Size, Randomisation, and Participants}

The number of caseworkers is fixed and determined by the structure of the organisation and work processes outlined in section 4.3. During the planning phase of the study, there were 17 caseworkers (12 regular ones and 5 from the youth team). Due to a re-organisation of tasks, changes in team membership and sick leaves, 15 caseworkers finally participated in the trial (of which 1 joined only later). The number of participants per caseworker is based on considerations of efficiency. A rule of thumb is that further gains in power become modest as soon as the number of participants per cluster is larger than the reciprocal value of the intracluster correlation coefficient $\rho$. With an assumed intracluster correlation coefficient $\rho$ of 0.05 , the optimal number of participants per caseworker is 20 (see Figure 4.2). ${ }^{5}$

With a sample size of 280 participants in 14 clusters, it is possible to detect effect sizes of approximately 0.51 standard deviations ( $\alpha=0.05$; two-tailed test; 1 $\beta=0.80) .{ }^{6}$ The previously cited studies on the effects of affirmation on feelings of self-worth, self-efficacy, or cognitive performance report effect sizes in this order of magnitude or larger.

5 We used the PowerUp! tool for calculating minimum detectable effect sizes and minimum required sample sizes (Dong \& Maynard, 2013).

6 The final sample consisted of 174 individuals in 15 clusters, which allows, given the same parameters, the detection of effect sizes of approximately 0.56 standard deviations. 


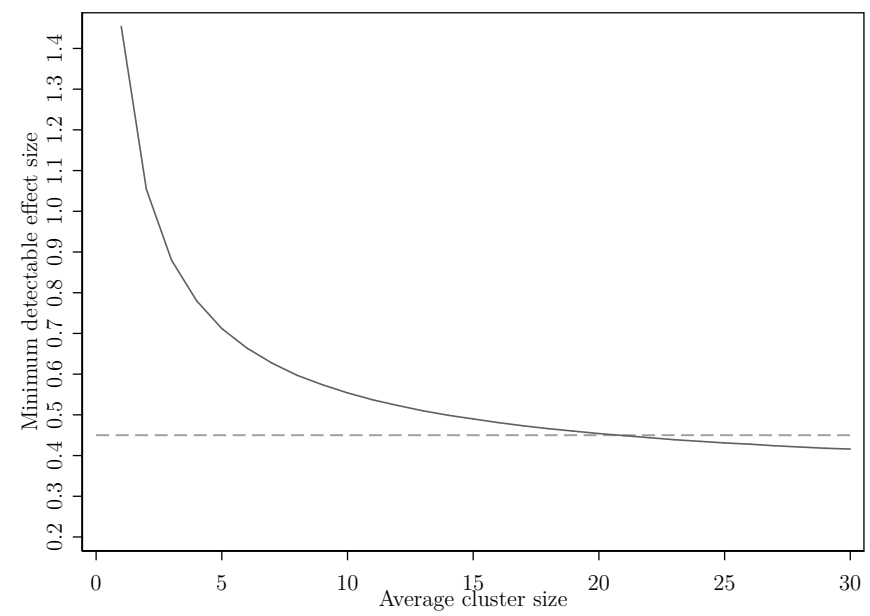

Figure 4.2: Average cluster size and minimum detectable effect size ( $\alpha=0.05$; twotailed test; $1-\beta=0.80, \mathrm{ICC}=0.05,17$ clusters)

Source: Author's own calculations.

It is more difficult to achieve balance between treatment arms with few clusters and since several caseworkers only dealt with young applicants, restricted randomisation was used to ensure balance based on team affiliation (Hayes \& Moulton, 2009). The randomtreat command (Carril, 2017) in Stata (version 15) was employed to assign the original 17 caseworkers to the treatment and control condition, stratified by team affiliation (regular intake team and team youth). A seed was set for replicability.

Nine caseworkers were initially allocated to the treatment and the remaining eight caseworkers to the control condition. When the implementation of the experiment started, the 14 caseworkers we worked with were equally distributed between treatment and control condition. Two caseworkers in the experimental and three in the control condition exclusively worked with young people. In the course of the experiment, one employee in the control group left the youth team and her replacement was allocated to the control group. Later, three new colleagues joined the youth team. Two of them were randomly allocated to the treatment group and one to the control group, but none of them ended up participating in the experiment. Given the type of intervention, treatment concealment was not possible at the level of the caseworkers. Participants, however, were not aware of the different experimental conditions.

At the cluster level, all caseworkers who conduct intake meetings were eligible, except for the two employees who were solely responsible for applicants in the nat- 
uralisation process. At the level of the participants, individuals had to be (1) older than 17 years and (2) legally competent. Moreover, caseworkers did not introduce the study if (3) language skills were seriously deficient, they had (4) any other doubts about the individual's mental capacity to provide informed consent, or if (5) the atmosphere at the beginning of the meeting was for some reason emotionally loaded or aggressive and the introduction of the study would therefore be out of place.

\subsubsection{Outcome Measures}

All outcomes were measured at the level of the participant. Directly after the intake meeting, participants were asked to privately fill in the survey. In addition, caseworkers filled in a brief survey after the intake meeting that asked them to assess the meeting from their point of view on a five-point scale (ranging from very negative to very positive). Caseworkers in the treatment condition were also asked whether it was possible to conduct the self-affirmation and if so, what the main topics of the self-affirmation were. The variables of interest were embedded in a paper-based survey on participants' satisfaction with the intake meeting (see Appendix B). The following dependent variables were measured:

Self-worth: Self-worth was measured with 14 items based on Critcher and Dunning (2015). Items were rated on nine-point Likert scales ranging from 1 (do not agree at all) to 9 (agree completely). The seven items on positive and the seven items on negative feelings were averaged separately to create indices of feelings of positive and negative self-worth. Furthermore, one general scale of feelings of selfworth was created based on all items, whereby the scores of the items on negative feelings were reversed.

Stress: The stress measure was based on three items presented by Creswell et al. (2005), but the wording was adjusted to refer to the meeting. Participants were asked to respond to statements on whether they experienced the meeting as stressful, difficult, or threatening. All items were measured on a five-point Likert scale that ranged from 1 (do not agree at all) to 5 (agree completely). The scores were averaged to create a composite measure of stress.

Societal belonging: Societal belonging was measured on an ordinal, six-point scale that ranged from 1 (low) to 6 (high). We adapted the inclusion of community in self scale (Mashek, Cannaday, \& Tangney, 2007). This scale is a single-item pictoral measure that offers a simple measure of community connectedness (see Figure 4.3). 
The measure consists of six pairs of circles. The first pair of circles does not overlap at all. In the following pairs, the overlap increases constantly until the sixth pair of circles nearly overlaps completely. We replaced 'community' by 'society' in our survey. Respondents received the explanation that in each image, the left circle represents themselves and the right circle refers to society. Society was defined broadly in the instructions as "all people together, and how they interact with each other".

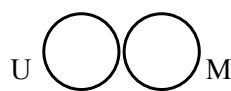

$\mathrm{U}$

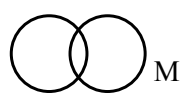

○

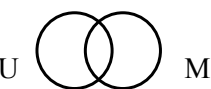

○
$\mathrm{U}$

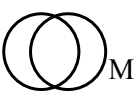

$\mathrm{U}$

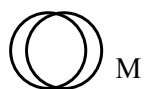

$\mathrm{U}$

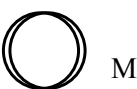

O

Figure 4.3: Adapted Inclusion of Community in Self (ICS) scale

Source: Author's own illustration based on Mashek et al. (2007).

Job search self-efficacy: The job search self-efficacy measure was based on Saks et al. (2015) as the authors distinguished explicitly between self-efficacy related to job search behaviour and outcomes. We left out some of the items or adjusted them in order to reflect more closely the Dutch context and the specific characteristics of our sample. Nine items referred to job search self-efficacy behaviour (for instance, belief that someone can prepare a good CV, plan weekly job search activities, or find appropriate vacancies) and seven items were related to job search self-efficacy outcomes (e.g. belief that someone can be invited to attend a job interview, or can find work quickly). All items were measured on five-point Likert scales ranging from 1 (not confident at all) to 5 (completely confident). Note that these questions were only included for participants who had no exemption from their job search requirements. Reasons for exemptions granted by the caseworker are, for instance, work incapacity, certain social circumstances, provision of informal care, or caring for children younger than five.

Cognitive performance: In line with Hall et al. (2014), cognitive performance was measured with a subsample of 12 Raven's Standard Progressive Matrices (RSPM). RSPM is considered a non-verbal estimate of fluid intelligence. These 12 out of 60 matrices were selected based on Bilker et al. (2012, Form A) who presented abbreviated forms of the RSPM that are highly predictive of the complete 60-item RSPM scale.

In addition, we collected information on respondents' sex, age, origin, civil status, household composition, previous benefit receipt, education, and work over the 
previous two years. These independent variables served two purposes. First, they were used to test randomisation balance and were included as control variables in order to reduce the variance of the estimator of the treatment effect (Duflo et al., 2008). Second, we hypothesised that the intervention may have different impacts for certain groups. We specified three subgroups based on educational attainment; having had social assistance in the past two years; and having had paid work in the past two years. Finally, the participants answered a section that focused on their satisfaction with the meeting, as this was of interest to the Social Services offices with which we collaborated. This section included statements about the content of the meeting, the caseworker, as well as an overall assessment of the meeting on a 10-point scale.

The survey for participants was checked for functional illiteracy by an expert. In light of the heterogeneity of backgrounds in terms of education and origin, we wanted to ensure that the survey was as accessible as possible for all participants. The research was approved by the Ethics Committee of Maastricht University (ERCPN 176 05_02_2017).

\subsubsection{Analytical Strategy}

The analyses are based on the intention-to-treat estimates of the effect of selfaffirmation. This means that the effect of being assigned to the treatment group is assessed rather than the effect of the treatment itself, as this reflects the policyrelevant effect of self-affirmation. ${ }^{7}$ The identification strategy takes into account the clustered random assignment. Failure to do so would lead to inflated Type-I error rates for the significance tests of regression coefficients, as the assumption of identically and independently distributed residuals would be ignored and standard errors underestimated (Hayes \& Moulton, 2009; McNeish \& Stapleton, 2016b). The basic model is an ordinary-least-squares regression. The standard errors are adjusted to reflect that observations are independent across caseworkers, yet not necessarily within caseworkers.

With our dataset, a further complication arose from the very small number of clusters. In order to model this appropriately and to understand the sensitivity of results to different methods, we used two further models that have previously

$7 \quad$ In any case, the self-affirmation exercise was implemented in 100 out of the 104 meetings in the treatment group. 
been shown to perform well with very few clusters (McNeish \& Stapleton, 2016b). The first model is a multilevel model, notationally written as follows (McNeish \& Stapleton, 2016b, p. 497):

$$
\mathbf{y}_{j}=\mathbf{X}_{j} \boldsymbol{\beta}+\mathbf{Z}_{j} \mathbf{u}_{j}+\boldsymbol{\epsilon}_{j}
$$

where $\mathbf{y}_{j}$ is a $m_{j} \times 1$ vector of responses for the cluster $j, m_{j}$ is the number of units within cluster $j, \mathbf{X}_{j}$ is a $m_{j} \times p$ design matrix of predictors in cluster $j$ (at either level in this notation), $p$ is the number of predictors (which includes the intercept), $\boldsymbol{\beta}$ is a $p \times 1$ vector of fixed regression coefficients, $\mathbf{Z}_{j}$ is a $m_{j} \times q$ design matrix for the random effects for cluster $j, q$ is the number of random effects, $\mathbf{u}_{j}$ is a $q \times 1$ vector of random effects for cluster $j, E\left(\mathbf{u}_{j}\right)=\mathbf{0}$ and $\operatorname{Cov}\left(\mathbf{u}_{j}\right)=\mathbf{G}$, where $\mathbf{G}$ is $q \times q$, and $\boldsymbol{\epsilon}_{j}$ is an $m_{j} \times 1$ vector of residuals of the observations in cluster $j$ where $E\left(\boldsymbol{\epsilon}_{j}\right)=\mathbf{0}$, $\operatorname{Cov}\left(\boldsymbol{\epsilon}_{j}\right)$ is $m_{j} \times m_{j}$, and $\mathbf{u}_{j}$ and $\boldsymbol{\epsilon}_{j}$ are independent $\left(\operatorname{Cov}\left[\mathbf{u}_{j}, \boldsymbol{\epsilon}_{j}\right]=\mathbf{0}\right)$.

Maximum likelihood estimation relies on asymptotic theory and yields good parameter estimates in large samples. In small samples, however, these properties are not assured. Particularly, $\boldsymbol{\epsilon}_{j}$ tends to be too low. As $\boldsymbol{\epsilon}_{j}$ goes into the estimation of the standard errors of the fixed effects, this negative effect can lead to standard errors that are too small. This, in turn, inflates Type-I errors and can lead to false discoveries. One alternative that alleviates this problem is to use restricted maximum likelihood estimation. However, due to the small number of clusters, there is still uncertainty in $\boldsymbol{\epsilon}_{j}$. In order to reflect this uncertainty and address the downward bias, we additionally implement the Kenward-Roger adjustment. This is the most widely used correction and has been recommended when samples size is small, the covariance structure is complicated and the data is unbalanced (McNeish \& Stapleton, 2016a; Yang, 2015).

The second model is a fixed effects models. Indicator variables are included for each cluster to account for the nested nature of the data. The model is notationally written as (the intercept is suppressed) (McNeish \& Stapleton, 2016b, p. 501):

$$
\mathbf{y}_{j}=\mathbf{X}_{j} \boldsymbol{\beta}+\alpha_{j} C_{j}+\mathbf{r}_{j}
$$

where $\mathbf{y}_{j}$ is a $m_{j} \times 1$ vector of responses for the $j$ th cluster, $\mathbf{X}$ is a $m_{j} \times p$ design matrix of substantive predictors, $\boldsymbol{\beta}$ is a $p \times 1$ vector of substantive regression coefficients, $\alpha_{j}$ is the cluster affiliation variable for cluster $C_{j}$, and $\mathbf{r}_{j}$ is the residual.

It is not possible to directly estimate the effects of Level-2 predictors, including 
the treatment effect, because of perfect multicollinearity of these predictors and the cluster affiliation predictors. The treatment effect is recovered by linear contrasts of the cluster affiliation variable coefficients. The weighted average of the cluster affiliation estimates for the treatment group are compared to the weighted average of the cluster affiliation estimates of the control group (McNeish \& Stapleton, 2016b). This requires the assumption that slopes of Level-1 predictors are homogenous across clusters. Furthermore, the reported standard errors for the recovered binary Level-2 predictor will be too small, as the software does not accommodate the fact that there needs to be a distinction between variance at Level-1 and at Level-2. To rectify this issue, the standard errors of the output are multiplied with the square root of the unconditional design effect (McNeish \& Stapleton, 2016b):

$$
D E F T=\sqrt{(1+(m-1) \times \rho)}
$$

where $m$ is the average cluster size and $\rho$ is the intracluster correlation that is calculated based on the unconditional model.

A final caveat of fixed effects models (as compared to multi-level models) is that cluster-specific questions can only be answered in a limited way. Inferences are only appropriate to the clusters in the data, but are not generalizable to the broader population of clusters since clusters are specified as fixed effects. However, this does not pose a problem for this study as we are interested in questions related to participants, not to caseworkers and their characteristics.

\subsection{Discussion of Results}

The final sample consisted of 174 individuals in 15 clusters. 104 individuals were in the treatment group and 70 in the control group. Table 4.1 provides a summary of the baseline statistics. The average age is 38 . The sample is evenly split between male and female participants. Three out of ten participants have a foreign background. The majority has completed lower or higher secondary education. Typically, individuals are single or single parents, or form part of the final category on household composition, i.e. live with their parents or other relatives. The large majority has never been married. Roughly one fourth of applicants has already had a social assistance benefit in the previous two years. Only one fifth had paid work in the previous two years. Reflecting the development of the labour market situation in the Netherlands, most people applied in the final quarter of 2017 or the 
first quarter of 2018. Typical topics of the self-affirmation exercise were family and friends, hobbies, or educational achievements.

The unequal distribution of individuals in the treatment and control condition raised concerns about whether the randomisation strategy had worked. Table 4.1 reports the results of a test of randomisation balance. Each covariate was regressed on treatment assignment, while controlling for caseworker fixed effects. With the exception of age, being a single parent, and application in the first quarter of 2018, none of the coefficients is significant at the 10-per cent level. The result for age is driven by the fact that there had been an unequal number of caseworkers in the youth team. With three of those caseworkers in the control and only two in the treatment group, the average age of applicants is higher in the treatment group. In the following analyses, all socio-economic variables are included as control variables.

Since the clustered nature of our data is a possible concern, Table 4.2 reports the ICC for all outcome variables. The sizes of all coefficients are very moderate and, in most cases, below the values that were assumed for the power calculations. Measurements of applicants who were treated by the same caseworker are only slightly more similar than measurements of applicants from different caseworkers. The distribution of outcome variables is shown in Figure 4.4. Visual inspection reveals that the outcome variables roughly follow a normal distribution. Furthermore, there are indications that job search behaviour self-efficacy and cognitive performance tend to be higher in the treatment group, whereas societal belonging appears to be higher in the control group.

In the next step, the data was modelled in line with our analytical strategy. Four results should be noted. First, we found little support for an average effect of the affirmation exercise, except for a moderate negative effect on societal belonging. This either means that self-affirmation has indeed no effect on the defined outcome variables; that the study is not sufficiently powered to detect effects; or that there are heterogenous treatment effects that depend on the characteristics of applicants. We therefore proceeded with the subgroup analyses. Second, the subgroup analyses revealed that results for the total sample indeed mask different dynamics at the subgroup level. In particular, self-affirmation had a negative effect for those individuals that had not received a social assistance benefit in the previous two years, but had paid work (Figure 4.5). Depending on the model, being in the treatment group increased negative feelings of self-worth by 0.6 to 1.0 units, which means that negative feelings were one third to one half standard deviations higher in the treated 
Table 4.1: Baseline summary statistics and test of balance for covariates

\begin{tabular}{|c|c|c|c|c|}
\hline & \multirow[b]{2}{*}{ Mean } & \multicolumn{2}{|c|}{ Test of randomisation balance } & \multirow[b]{2}{*}{$N$} \\
\hline & & Coefficient & $p$-value & \\
\hline Age & 38.35 & 21.38 & 0.064 & 174 \\
\hline Male & 0.49 & -0.38 & 0.467 & 86 \\
\hline Foreign background & 0.28 & 0.31 & 0.501 & 48 \\
\hline \multicolumn{5}{|l|}{ Education } \\
\hline No/special & 0.06 & 0.06 & 0.805 & 11 \\
\hline Basic & 0.10 & 0.13 & 0.698 & 18 \\
\hline Lower secondary & 0.37 & 0.25 & 0.622 & 64 \\
\hline Higher secondary & 0.29 & -0.75 & 0.108 & 51 \\
\hline Tertiary & 0.17 & 0.31 & 0.418 & 30 \\
\hline \multicolumn{5}{|l|}{ Household composition } \\
\hline Single & 0.47 & 0.63 & 0.215 & 81 \\
\hline Partner & 0.09 & 0.00 & 1.000 & 15 \\
\hline Single parent & 0.15 & -0.75 & 0.033 & 26 \\
\hline Family & 0.04 & 0.00 & 1.000 & 6 \\
\hline Other & 0.24 & 0.13 & 0.761 & 46 \\
\hline \multicolumn{5}{|l|}{ Civil status } \\
\hline Never married & 0.68 & -0.31 & 0.481 & 118 \\
\hline Married & 0.11 & 0.00 & 1.000 & 19 \\
\hline Divorced or widowed & 0.21 & 0.31 & 0.449 & 36 \\
\hline PW benefit in previous 2 years & 0.27 & -0.60 & 0.197 & 47 \\
\hline Paid work in previous 2 years & 0.20 & 0.25 & 0.545 & 34 \\
\hline \multicolumn{5}{|l|}{ Quarter of intake meeting } \\
\hline $4 / 2017$ & 0.39 & 0.31 & 0.527 & 68 \\
\hline $1 / 2018$ & 0.36 & -0.75 & 0.057 & 63 \\
\hline $2 / 2018$ & 0.20 & 0.19 & 0.301 & 34 \\
\hline $3 / 2018$ & 0.04 & 0.25 & 0.614 & 6 \\
\hline $4 / 2018$ & 0.02 & 0.00 & 1.000 & 3 \\
\hline
\end{tabular}

Source: Author's own calculations.

Notes: All covariates are reported. The second column reports the sample mean. The third and fourth column report the coefficients and $p$-values from ordinary least squares regressions of each covariate on assignment to treatment, controlling for caseworker fixed effects. $N=174$.

group. We also observed that the increased negative feelings of societal belonging seem to be driven by people with a higher education and who have not received a social assistance benefit in the previous two years (Figure 4.6). By contrast, self- 
Table 4.2: Intracluster correlation coefficients

\begin{tabular}{|c|c|c|c|c|c|c|}
\hline \multirow[b]{3}{*}{ Positive feelings self-worth } & \multicolumn{2}{|c|}{ All } & \multicolumn{2}{|c|}{ Treatment } & \multicolumn{2}{|c|}{ Control } \\
\hline & ICC & S.E. & ICC & S.E. & ICC & S.E. \\
\hline & 0.000 & 0.036 & 0.035 & 0.059 & 0.000 & 0.074 \\
\hline Negative feelings self-worth & 0.000 & 0.036 & 0.000 & 0.042 & 0.017 & 0.081 \\
\hline Stress & 0.072 & 0.060 & 0.036 & 0.061 & 0.183 & 0.145 \\
\hline $\begin{array}{l}\text { Job search behaviour self- } \\
\text { efficacy }\end{array}$ & 0.046 & 0.062 & 0.116 & 0.110 & 0.000 & 0.098 \\
\hline Societal belonging & 0.050 & 0.054 & 0.109 & 0.010 & 0.000 & 0.072 \\
\hline Cognitive performance & 0.028 & 0.049 & 0.000 & 0.048 & 0.147 & 0.138 \\
\hline
\end{tabular}

Source: Author's own calculations.

Notes: The second to seventh column show the intracluster correlation coefficients (ICC) and the asymptotic standard errors (S.E.) for all outcome variables; for the complete sample and the treatment and control groups separately.

affirmation boosted job search behaviour self-efficacy among individuals with lower levels of education (Figure 4.7). Job search behaviour self-efficacy, measured on a five-point scale, was 0.4 to 0.6 points higher among affirmed individuals. This is exactly the size of the gap in job search self-efficacy between individuals with lower levels of education (3.1 points) and individuals with higher levels of education (3.7 points). To put this further into perspective, job search behaviour self-efficacy is approximately half a standard deviation higher among self-affirmed individuals. The order of magnitude reflects results found in health studies cited above.

Third, results are consistent across different specifications. While point estimates are typically of the same order of magnitude, the level of uncertainty differs across the methods. Nonetheless, the consistent patterns, regardless of the method that was used, illustrate that the main results are not sensitive to the chosen method. Fourth, putting together the different results, a more general story line emerges. There are indications that self-affirmation can have positive effects for persons that face more challenges to (re)integrate into the labour market, proxied by lower levels of educational attainment, social assistance receipt in the previous two years, and an absence of paid work in the same period. Most importantly, job search behaviour self-efficacy is boosted, which is a critical component for successful job search. On the contrary, self-affirmation may lead to lower feelings of self-worth and societal belonging among people with better labour market perspectives - indicated by higher levels of education, being in paid work in the previous two years, or having had no social assistance in the previous two years. 

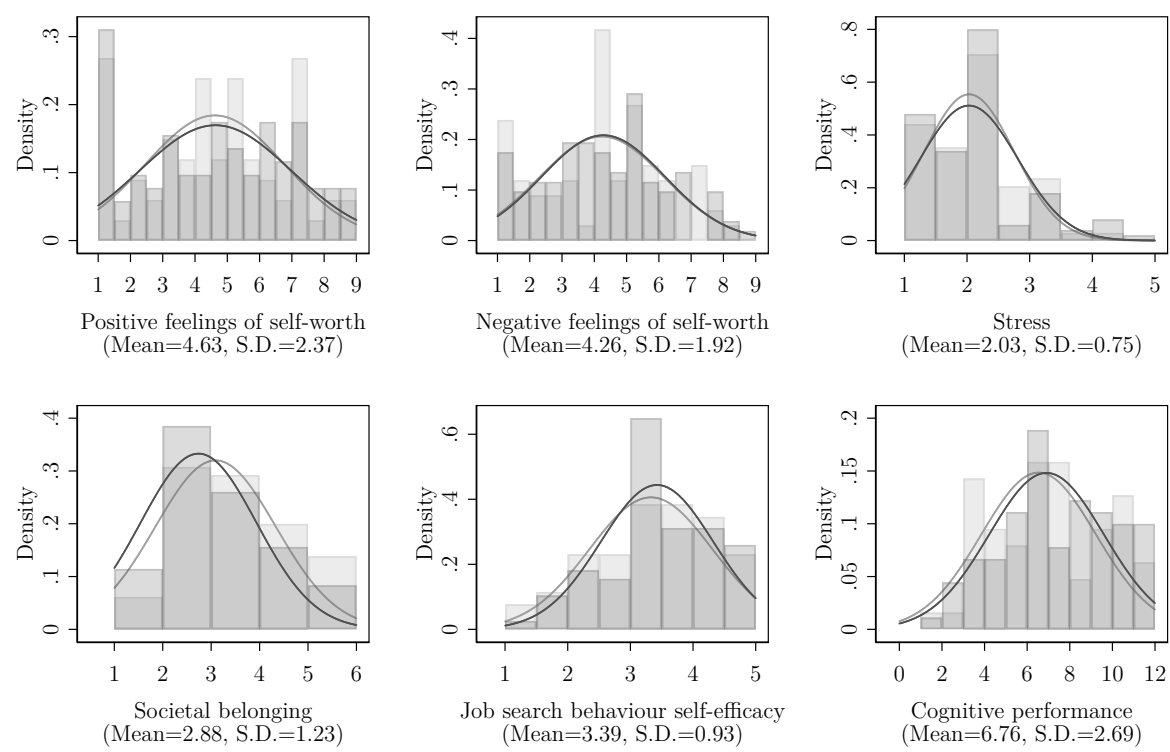

Control

Treatment

Figure 4.4: Histograms and kernel density of outcome variables, by treatment and control group

Source: Author's own calculations.

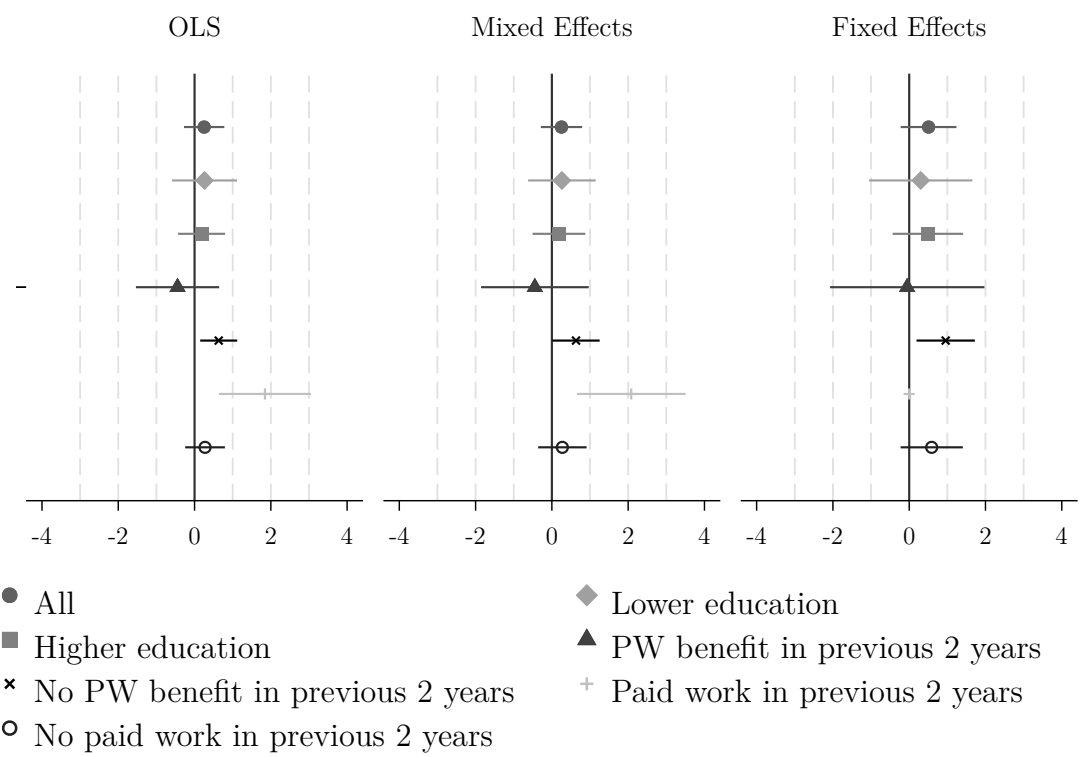

Figure 4.5: Comparison of estimation results by different methods and subgroups: Negative feelings of self-worth

Source: Author's own calculations.

Notes: The markers indicate the point estimates and the extending lines the 90-per cent confidence intervals. In all models, control variables are included. The graph is created in Stata with the coefplot command developed by Jann (2014). 

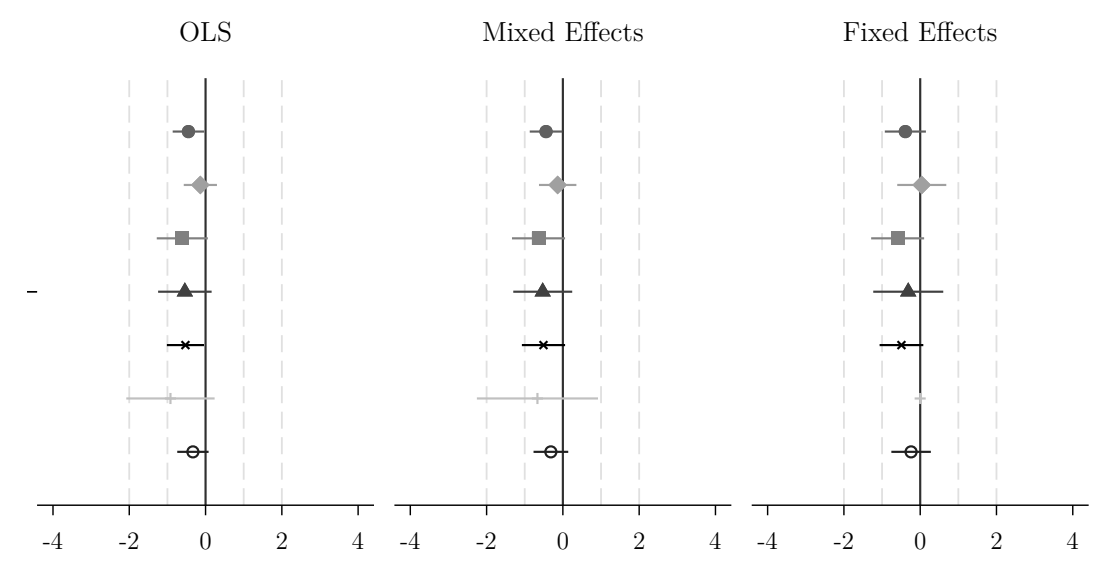

- All

$\checkmark$ Lower education

- Higher education

- PW benefit in previous 2 years

× No PW benefit in previous 2 years

+ Paid work in previous 2 years

$\circ$ No paid work in previous 2 years

Figure 4.6: Comparison of estimation results by different methods and subgroups: Societal belonging

Source and notes: See Graph 4.5.

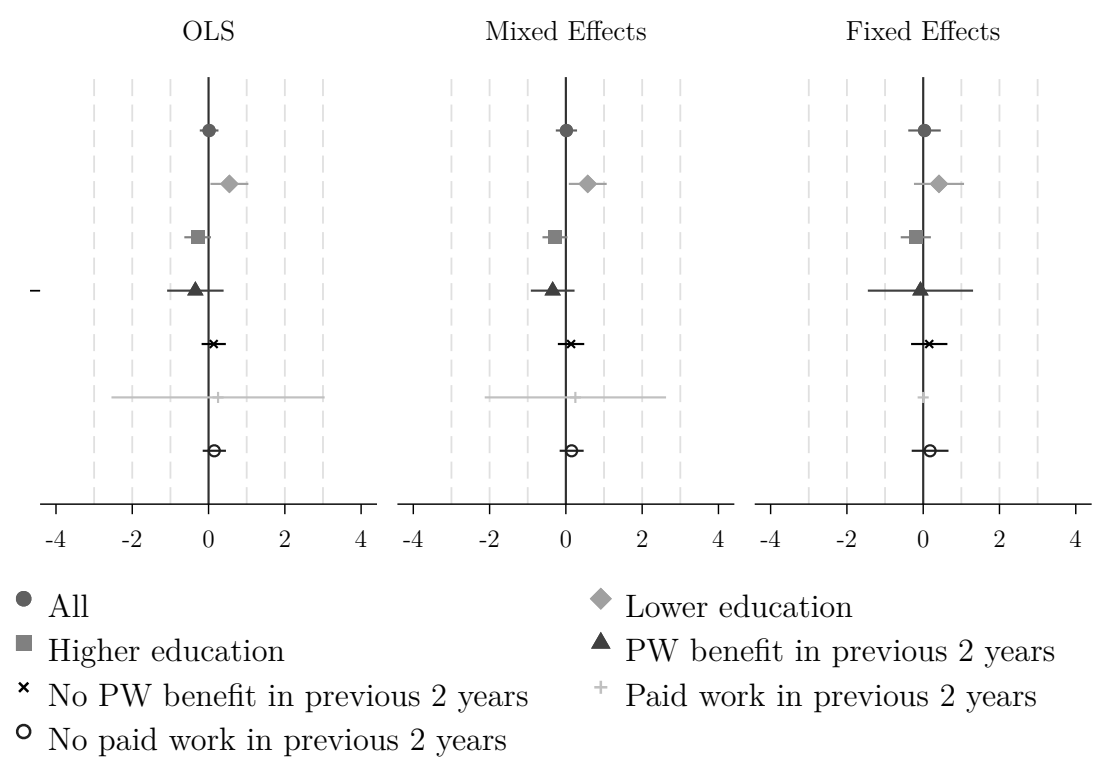

Figure 4.7: Comparison of estimation results by different methods and subgroups: Job search behaviour self-efficacy

Source and notes: See Graph 4.5. 
The results echo previous findings in effect studies on motivational interviewing. In an overview of effect studies by Macdonald (2007, quoted in Bannink (2013)), the author concluded that motivational interviewing worked better for persons with lower socio-economic status. Still, the question remains what mechanisms can explain this finding in our context. According to Critcher and Dunning's (2015) 'affirmation as perspective' model, the point of departure is that someone's self-concept is dominated by a damaged identity. As a result, self-evaluations are disproportionately dominated by this threatened domain. It is conceivable that this is indeed the case for individuals who have found themselves in a threatening situation without paid work, social assistance receipt, and low levels of education. These feelings could have been exacerbated by social interactions that have consolidated the damaged identity over years. In this situation of constant perceptions of environmental threats, the self-affirmation exercise could redirect the focus from the threatened to a valued domain and restore a broader perspective on the self. For individuals with higher educational attainment, paid work and no social assistance benefit in the previous two years, the self-affirmation might lead to exactly the opposite effect. Instead of restoring a positive self-image, it might rather serve as a reminder of a threat. Possibly, it serves to emphasise the consequence of newly belonging to a group that is threatened by stereotypes in society. Rather than turning the spotlight away from the damaged identity, the self-affirmation could make it loom larger and thereby lead to more negative self-evaluations and tendencies to detach oneself from society.

\subsection{Conclusion}

Based on previous research on self-affirmation and motivational interviewing, this chapter developed an oral self-affirmation that is suitable to be used in Social Services offices, or other services and agencies where caseworkers and recipients directly interact with each other. The aim of this short and low-cost intervention is to restore personal integrity in situations in which it is challenged by the surrounding environment. In addition to job loss, other applications of the self-affirmation are conceivable, for example debt counselling or child protection. The newly designed protocol was tested in a clustered randomised trial with 15 caseworkers and 174 citizens that ran for 15 months in a Dutch Social Services office.

The results emphasise the importance of taking into account individual characteristics. Overall, we find little effect of this one-time affirmation on individuals' 
feelings of self-worth, stress, societal belonging, self-efficacy, and cognitive performance. Sub-group analyses show, however, heterogeneous effects, suggesting that recipients' characteristics play a role. There are potential adverse effects for individuals with better labour market perspectives - characterised by higher education, paid work and no social assistance benefit in the previous two years. For these citizens, the exercise seems to act as a reminder of their new identity in a group that is potentially vulnerable to stereotype threats, and can lead to heightened feelings of negative self-worth and detachment from society. For individuals with lower levels of education, no paid job and/or social assistance benefits in the previous two years, we do not find those same effects. On the contrary, the exercise serves to boost job search behaviour self-efficacy, an important building block of many job search interventions. From a policy perspective, this means that caseworkers need to be sensitised to the conditions under which they can use this intervention. Applied appropriately, this instrument is potentially a catalyst for improved job search behaviour self-efficacy.

We could cast the net even wider. Our research was motivated by the observation of welfare stigma and its negative repercussions on how people think, behave, and navigate their lives. The self-affirmation was then conducted during the first longer meeting at the Social Services office. Yet, evidence suggests that there are people who do not apply for benefits at all, despite being in need and eligible. Based on rich Dutch administrative data, Tempelman and Houkes-Hommes (2016) estimated that one in six Dutch households did not take up an income-dependent health-care allowance. The likelihood of take-up in general increases as income decreases, but this relationship does not hold for the group with the lowest income and wealth that does not have the highest take-up rates. Information is a crucial factor, but another, non-tested explanation could be that for those individuals, the stigma effects looms largest. This would call for self-affirmation interventions to increase the openness to potentially threatening information, as demonstrated by Hall et al. (2014) in an urban soup kitchen. It would also be necessary to identify appropriate places to get in touch with individuals outside the Social Services office, such as food banks or neighbourhood centres.

In light of the overall topic of this thesis, it would be possible to criticise the self-affirmative exercise for targeting a symptom rather than the root cause of the problem, namely the stigmatisation of social assistance recipients and the fact of making them responsible for their own predicament. It is certainly true that this study might be thought to distract attention away from underlying structural prob- 
lems. Nonetheless, there are convincing arguments in favour of such an exercise. First, whereas it is correct that social exclusion and stigma need to be tackled directly, such a discussion and changes will not come easily and need time to materialise. Provided that we do not lose sight of the ultimate causes, there should be nothing wrong with finding ways to at least alleviate the symptoms in the short term. Second, as the self-affirmation exercise is embedded in a recipient-caseworker interaction, it does not understand the individual welfare recipient in isolation. Even though this is not the society at large, this is at least a first step; the exercise in the end does not only open up the perspectives of recipients, but arguably also of caseworkers.

This research opens up new avenues for further studies. To start with, the extent to which these results can be generalised may need to be put to the test by replicating the exercise in other offices and, if possible, with more participants. In that way, it would be possible to detect smaller effects. Given the low cost both in time and money, effects of a smaller order of magnitude could still be relevant. Second, even though we provide a possible explanation of the reasons for heterogeneous treatment effects, this should be tested more rigorously. The benefit of a better understanding of underlying mechanisms is that the use of this intervention can be fine-tuned. Third, it remains to be seen how long these effects can be sustained and whether or not further outcomes in the long-run could be positively affected. 


\section{References}

Bandura, A. (1994). Self-efficacy. In V. S. Ramachaudran (Ed.), Encyclopedia of human behavior (Vol. 4, p. 71-81). New York, NY: Academic Press.

Banker, S., Bhanot, S., \& Deshpande, A. (2018, March 29). Poverty identity and competitiveness. Retrieved November 27, 2018, from https://www . haverford.edu/sites/default/files/Department/ Economics/Poverty-Identity-and-Competitiveness .pdf

Bannink, F. (2013). Oplossingsgerichte vragen. Handboek oplossingsgerichte gespreksvoering. Amsterdam, the Netherlands: Pearson.

Baumberg, B. (2016). The stigma of claiming benefits: A quantitative study. Journal of Social Policy, 45(2), 181-199.

Behncke, S., Frölich, M., \& Lechner, M. (2009). Targeting labour market programmes: Results from a randomized experiment. Swiss Journal of Economics and Statistics, 145(3), 221-268.

Bertrand, M., Luttmer, E. F., \& Mullainathan, S. (2000). Network effects and welfare cultures. The Quarterly Journal of Economics, 115(3), 1019-1055.

Bilker, W. B., Hansen, J. A., Brensinger, C. M., Richard, J., Gur, R. E., \& Gur, R. C. (2012). Development of abbreviated nine-item forms of the Raven's Standard Progressive Matrices Test. Assessment, 19(3), 354-369.

Borm, G. F., Melis, R. J., Teerenstra, S., \& Peer, P. G. (2005). Pseudo cluster randomization: A treatment allocation method to minimize contamination and selection bias. Statistics in Medicine, 24(23), 3535-3547.

Borman, G. D. (2017). Advancing values affirmation as a scalable strategy for mitigating identity threats and narrowing national achievement gaps. Proceedings of the National Academy of Sciences, 114(29), 7486-7488.

Carril, A. (2017). Dealing with misfits in random treatment assignment. The Stata Journal, 17(3), 652-667.

Centraal Bureau voor de Statistiek. (2019). StatLine. Retrieved January 3, 2019, from https://opendata.cbs.nl/statline/\#/CBS/nl/

Cohen, G. L., Garcia, J., Purdie-Vaughns, V., Apfel, N., \& Brzustoski, P. (2009). Recursive processes in self-affirmation: Intervening to close the minority achievement gap. Science, 324(5925), 400-403.

Cohen, G. L., \& Sherman, D. K. (2014). The psychology of change: Self-affirmation and social psychological intervention. Annual Review of Psychology, 65, 333371. 
Cook, J. E., Purdie-Vaughns, V., Garcia, J., \& Cohen, G. L. (2012). Chronic threat and contingent belonging: Protective benefits of values affirmation on identity development. Journal of Personality and Social Psychology, 102(3), 479-496.

Creswell, J. D., Dutcher, J. M., Klein, W. M., Harris, P. R., \& Levine, J. M. (2013). Self-affirmation improves problem-solving under stress. PLoS One, 8(5), 1-7.

Creswell, J. D., Lam, S., Stanton, A. L., Taylor, S. E., Bower, J. E., \& Sherman, D. K. (2007). Does self-affirmation, cognitive processing, or discovery of meaning explain cancer-related health benefits of expressive writing? Personality and Social Psychology Bulletin, 33(2), 238-250.

Creswell, J. D., Welch, W. T., Taylor, S. E., Sherman, D. K., Gruenewald, T. L., \& Mann, T. (2005). Affirmation of personal values buffers neuroendocrine and psychological stress responses. Psychological Science, 16 (11), 846-851.

Critcher, C. R., \& Dunning, D. (2015). Self-affirmations provide a broader perspective on self-threat. Personality and Social Psychology Bulletin, 41(1), 3-18.

Cuddy, A. J., Fiske, S. T., \& Glick, P. (2007). The bias map: Behaviors from intergroup affect and stereotypes. Journal of Personality and Social Psychology, 92(4), 631-648.

Currie, J. M. (2006). The invisible safety net: Protecting the nation's poor children and families. Princeton, NJ: Princeton University Press.

Currie, J. M., \& Grogger, J. (2001). Explaining recent declines in food stamp program participation. Brookings-Wharton Papers on Urban Affairs, 203244.

Dong, N., \& Maynard, R. (2013). PowerUp!: A tool for calculating minimum detectable effect sizes and minimum required sample sizes for experimental and quasi-experimental design studies. Journal of Research on Educational Effectiveness, 6(1), 24-67.

Donner, A., \& Klar, N. (2004). Pitfalls of and controversies in cluster randomization trials. American Journal of Public Health, 94 (3), 416-422.

Duflo, E., Glennerster, R., \& Kremer, M. (2008). Using randomization in development economics research: A toolkit. In T. Schultz \& J. Strauss (Eds.), Handbook of development economics (Vol. 4, pp. 3895-3962). Amsterdam, the Netherlands: North Holland.

Ehret, P. J., LaBrie, J. W., Santerre, C., \& Sherman, D. K. (2015). Self-affirmation and motivational interviewing: Integrating perspectives to reduce resistance and increase efficacy of alcohol interventions. Health Psychology Review, 9(1), 83-102.

Epton, T., \& Harris, P. R. (2008). Self-affirmation promotes health behavior change. 
Health Psychology, 27(6), 746-752.

Fiske, S. T., Cuddy, A. J., Glick, P., \& Xu, J. (2002). A model of (often mixed) stereotype content: Competence and warmth respectively follow from perceived status and competition. Journal of Personality and Social Psychology, 82(6), 878-902.

Garthwaite, K. (2016). Hunger pains. Life inside foodbank Britain. Bristol, United Kingdom: Policy Press.

Gennetian, L. A., \& Shafir, E. (2015). The persistence of poverty in the context of financial instability: A behavioral perspective. Journal of Public Policy Analysis and Management, 34(4), 904-936.

Glennerster, R. (2014). Choosing the level of randomization. Retrieved August 29, 2017, from https://www.google.nl/search?q=rachel+glennerster+ coosing+the+lvel+of+randomisation\&ie=utf $-8 \& o e=u t f-8 \& c l i e n t=$ firefox-b-ab\&gfe_rd=cr\&dcr=0\&ei=DI-IWaStCsf G8Aex1Zd4

Gubrium, E., \& Lødemel, I. (2014). 'Not good enough': Social assistance and shaming in Norway. In E. Gubrium, S. Pellissery, \& I. Lødemel (Eds.), The shame of it: Global perspectives on anti-poverty policies (pp. 85-110). Bristol, United Kingdom: Policy Press.

Hall, C. C., Zhao, J., \& Shafir, E. (2014). Self-affirmation among the poor: Cognitive and behavioral implications. Psychological Science, 25(2), 619-625.

Handler, J. F., \& Hollingsworth, E. J. (1969). Stigma, privacy, and other attitudes of welfare recipients. Stanford Law Review, 22(1), 1-19.

Haushofer, J., \& Fehr, E. (2014). On the psychology of poverty. Science, $344(6186)$, 862-867.

Hayes, R. J., \& Moulton, L. H. (2009). Cluster randomised trials. Boca Raton, FL: Chapman \&Hall/CRC Press.

Hutton, J. L. (2001). Are distinctive ethical principles required for cluster randomized controlled trials? Statistics in Medicine, 20(3), 473-488.

Jann, B. (2014). Plotting regression coefficients and other estimates. The Stata Journal, 14(4), 708-737.

Kampen, T. (2014). Verplicht vrijwilligerswerk: De ervaringen van bijstandscliënten met een tegenprestatie voor hun uitkering (Unpublished doctoral dissertation). University of Amsterdam, Amsterdam, the Netherlands.

Kanfer, R., \& Bufton, G. (2015). Job loss and job search: A social-cognitive/selfregulation perspective. In U.-C. Klehe \& E. A. van Hooft (Eds.), The Oxford handbook of job loss and job search. Oxford Handbooks Online. doi: 10.1093/ oxfordhb/9780199764921.013.002 
Kanfer, R., Wanberg, C. R., \& Kantrowitz, T. M. (2001). Job search and employment: a personality-motivational analysis and meta-analytic review. Journal of Applied Psychology, 86(5), 837-855.

Karlan, D., \& Appel, J. (2016). Failing in the field: What we can learn when field research goes wrong. Princeton, NJ: Princeton University Press.

Kunze, L., \& Suppa, N. (2017). Bowling alone or bowling at all? The effect of unemployment on social participation. Journal of Economic Behavior $\&$ Organization, 133, 213-235.

Lee, W.-S., \& Oguzoglu, U. (2007). Income support and stigma effects for young Australians. Australian Economic Review, 40(4), 369-384.

Lister, R. (2004). Poverty. Cambridge, United Kingdom: Polity.

Lister, R. (2015). 'To count for nothing': Poverty beyond the statistics. Journal of the British Academy, 3, 139-165.

Liu, S., Huang, J. L., \& Wang, M. (2014). Effectiveness of job search interventions: A meta-analytic review. Psychological Bulletin, 140(4), 1009-1041.

Maastricht-Heuvelland. (2014). Beleidsplan Participatiewet Maastricht-Heuvelland 2015. Sociaal Domein.

Macdonald, A. (2007). Solution-focused therapy. Theory, research 8 practice. London, United Kingdom: SAGE Publications.

Malmberg-Heimonen, I., \& Tøge, A. G. (2016). Effects of individualised follow-up on activation programme participants' self-sufficiency: A cluster-randomised study. International Journal of Social Welfare, 25(1), 27-35.

Martens, A., Johns, M., Greenberg, J., \& Schimel, J. (2006). Combating stereotype threat: The effect of self-affirmation on women's intellectual performance. Journal of Experimental Social Psychology, 42(2), 236-243.

Mashek, D., Cannaday, L. W., \& Tangney, J. P. (2007). Inclusion of community in self scale: A single-item pictorial measure of community connectedness. Journal of Community Psychology, 35(2), 257-275.

McNeish, D., \& Stapleton, L. M. (2016a). The effect of small sample size on two-level model estimates: A review and illustration. Educational Psychology Review, 28(2), 295-314.

McNeish, D., \& Stapleton, L. M. (2016b). Modeling clustered data with very few clusters. Multivariate Behavioral Research, 51(4), 495-518.

McQueen, A., \& Klein, W. M. (2006). Experimental manipulations of selfaffirmation: A systematic review. Self and Identity, 5 (4), 289-354.

Miyake, A., Kost-Smith, L. E., Finkelstein, N. D., Pollock, S. J., Cohen, G. L., \& Ito, T. A. (2010). Reducing the gender achievement gap in college science: A 
classroom study of values affirmation. Science, 330(6008), 1234-1237.

Moffitt, R., et al. (1983). An economic model of welfare stigma. American Economic Review, 73 (5), 1023-1035.

Ohls, C. (2017). A qualitative study exploring matters of ill-being and well-being in Norwegian activation policy. Social Policy and Society, 16(4), 593-606.

Patrick, R. (2016). Living with and responding to the 'scrounger' narrative in the UK: Exploring everyday strategies of acceptance, resistance and deflection. Journal of Poverty and Social Justice, 24 (3), 245-259.

Patrick, R. (2017). For whose benefit? The everyday realities of welfare reform. Bristol, United Kingdom: Policy Press.

Reed, M. B., \& Aspinwall, L. G. (1998). Self-affirmation reduces biased processing of health-risk information. Motivation and Emotion, 22(2), 99-132.

Saks, A. M., Zikic, J., \& Koen, J. (2015). Job search self-efficacy: Reconceptualizing the construct and its measurement. Journal of Vocational Behavior, 86, 104114.

Schmader, T., Johns, M., \& Forbes, C. (2008). An integrated process model of stereotype threat effects on performance. Psychological Review, 115 (2), 336356.

Schmeichel, B. J., \& Vohs, K. (2009). Self-affirmation and self-control: Affirming core values counteracts ego depletion. Journal of Personality and Social Psychology, 96(4), 770-782.

Shafir, E. (2017). Decisions in poverty contexts. Current Opinion in Psychology, $18,131-136$.

Sheehy-Skeffington, J., \& Rea, J. (2017). How poverty affects people's decisionmaking processes. Joseph Rowntree Foundaction.

Sherman, D. K. (2013). Self-affirmation: Understanding the effects. Social and Personality Psychology Compass, 7(11), 834-845.

Sherman, D. K., Bunyan, D. P., Creswell, J. D., \& Jaremka, L. M. (2009). Psychological vulnerability and stress: The effects of self-affirmation on sympathetic nervous system responses to naturalistic stressors. Health Psychology, 28(5), 554-562.

Sherman, D. K., \& Cohen, G. L. (2006). The psychology of self-defense: Selfaffirmation theory. Advances in Experimental Social Psychology, 38, 183-242.

Spencer, S. J., Fein, S., \& Lomore, C. D. (2001). Maintaining one's self-image vis-à-vis others: The role of self-affirmation in the social evaluation of the self. Motivation and Emotion, 25(1), 41-65.

Tempelman, C., \& Houkes-Hommes, A. (2016). What stops Dutch households from 
taking up much needed benefits? The Review of Income and Wealth, 62(4), 685-705.

Torgerson, D. J. (2001). Contamination in trials: is cluster randomisation the answer? British Medical Journal, 322(7282), 355-357.

Vohs, K. D., Park, J. K., \& Schmeichel, B. J. (2013). Self-affirmation can enable goal disengagement. Journal of Personality and Social Psychology, 104(1), $14-27$.

Walton, G. M., \& Spencer, S. J. (2009). Latent ability grades and test scores systematically underestimate the intellectual ability of negatively stereotyped students. Psychological Science, 20(9), 1132-1139.

Wears, R. L. (2002). Advanced statistics: Statistical methods for analyzing cluster and cluster-randomized data. Academic Emergency Medicine, 9(4), 330-341.

Weiss, A. R., Rockenbach, B., Schneiders, S., \& Vollan, B. (2017). Self-affirmation and productivity among the poor: A field experiment in rural Namibia. Retrieved from https://asfee2017.sciencesconf .org/145644/document

Wright, S. (2016). Conceptualising the active welfare subject: Welfare reform in discourse, policy and lived experience. Policy \& Politics, 44 (2), 235-252.

Yang, X. (2015). Small-sample inference for linear mixed-effects models. Presentation at 2015 Stata Conference.

Zhao, X., \& Nan, X. (2010). Influence of self-affirmation on responses to gain-versus loss-framed antismoking messages. Human Communication Research, 36(4), 493-511. 


\section{Professional Judgements at Work? \\ A Factorial Survey Experiment on Activation Workers' Decision-Making}

\section{$5.1 \quad$ Introduction}

For citizens, the welfare state usually manifests itself through their experiences with street-level organisations - those public bureaucracies and private agencies that link policies and people (Brodkin, 2013a). ${ }^{1}$ Lipsky (1980) famously argued that streetlevel organisations are not simply agents of the state, but have wide discretion in making decisions for citizens. He shifted the analytical lens to understand streetlevel bureaucrats as de facto policy mediators who negotiate and produce policy at the frontline. Brodkin (2013a) extended this view and argued that street-level organisations are also mediators of politics, as they structure possibilities for voice, rights and redress - especially for disadvantaged or marginalised groups for whom political institutions might be less accessible. The decisive role of frontline workers as mediators of policy and politics is particularly resonant in the field of activation. Activation policy combines income support with strategies to move people without employment back to work (Lødemel \& Moreira, 2014). Research has shown that frontline practices, such as the discretion that activation workers have and how they exercise it, are shaped by a number of contextual factors (Caswell, Kupka, Larsen, \& van Berkel, 2017). These include the content and regulation of activation policy, as well as governance, organisational and occupational contexts.

Previous studies have pointed at the diversity of frontline practices and the contexts in which they take place. This encompasses variations in activation workers' education and job design, preferences, role interpretations and, ultimately, treatment of citizens (De Wilde \& Marchal, 2018; Eikenaar, de Rijk, \& Meershoek, 2016;

1 The author would like to thank all participants and Maastricht Heuvelland Social Services for their cooperation, and the administrative and financial support provided. Comments on earlier versions of this chapter were provided by Franziska Gassmann, Lonneke Nillesen, Keetie Roelen, Fred Zijlstra, and participants at the Welfare Conditionality Conference at York University from 26-28 June 2018. 
Nothdurfter, 2016; van Berkel \& Knies, 2018). These studies typically use qualitative approaches that provide nuanced accounts of factors, mechanisms and contexts that shape activation workers' decisions (van Berkel, 2017a). However, these study approaches do not allow for causal relationships to be established and the distinct effects on decision-making of often correlated factors, for instance citizen characteristics, cannot be disentangled. Moreover, these studies cannot uncover activation workers' tacit knowledge and intuitions.

This chapter therefore aims to answer the following questions using an experimental approach: To what extent do activation workers agree in their decisionmaking and share norms of action? To what extent do disagreements in decisionmaking reflect different role interpretations of activation workers? This chapter contributes to opening up the black box of activation workers' decision-making. It systematically explores agreements and disagreements in judgements of activation workers using a novel approach that so far has only rarely been employed in this context. The chapter is grounded in Wallander and Molander's (2014) framework for understanding professional discretion. Agreements in discretionary reasoning allow us to identify common norms that activation workers use to arrive at a conclusion of what to do based on the description of a hypothetical beneficiary (Wallander \& Molander, 2014). At the same time, the analysis of disagreements in discretionary reasoning shows to what extent these stem from differences across individual activation workers or, possibly, varying role interpretations (Eikenaar et al., 2016; Nothdurfter, 2016; Wallander \& Molander, 2014). This is done by means of a purpose-designed factorial survey experiment and multi-level analysis of this data.

The results of this chapter can be used to elucidate activation workers' decisionmaking and strengthen the development of a reintegration profession (Eikenaar et al., 2016). The results also have implications for social assistance recipients, as different judgements create different opportunities or constraints for the same citizen (Eikenaar et al., 2016). In the words of Lipsky (1980), "the ways in which street-level bureaucrats deliver benefits and sanctions structure and delimit people's lives and opportunities" (p. 4); "they hold the keys to a dimension of citizenship" (p. 4). The following section reviews related literature and identifies the research gap. Section 5.3 presents the conceptual framework and the hypotheses, which is followed by an introduction of the context of Dutch activation frontline work in Section 5.4. Section 5.5 outlines the research methods and Section 5.6 presents and discusses the results. 


\section{$5.2 \quad$ Related Literature}

In the context of activation, frontline workers and their practices are the "missing middle" (Brodkin, 2013b, p.8) between policies and people. Their key role has only more recently been recognised in European countries (Nothdurfter, 2016; van Berkel $\&$ van der Aa, 2012). Frontline workers, or here specifically activation workers, are defined as "public service workers who interact directly with citizens in the course of their jobs and who have substantial discretion in the execution of their work" (Lipsky, 1980, p. 3). Activation is the "policy of designing benefit rules and employment/training services with a view at moving unemployed income benefit recipients into work" (Lødemel \& Moreira, 2014, p.8). The contexts in which activation work is carried out vary largely. At the same time, these contexts shape activation practices, that is, the actual delivery of activation policies (Caswell, Kupka, et al., 2017). Four contexts are particularly relevant, namely the context in terms of content and regulation of activation policy, and the governance, organisational and occupational contexts (Caswell, Kupka, et al., 2017).

In terms of policy content, activation workers have to balance different types of activation instruments. The literature typically creates a dichotomy between elements that intervene to increase job search efforts and the probability of job take-up, and approaches that foster human capital through education and training. The former strategy incentivises or mandates desired behavioural change by means of the duration or level of benefits, the prescription of individual activity requirements, and/or sanctioning clauses. This has been denoted as a demanding, incentive-centred, or recommodifying approach (Dingeldey, 2007; Eichhorst, Kaufmann, Konle-Seidl, \& Reinhard, 2008; Marchal \& Mechelen, 2017). The latter strategies aim at increasing an individual's employability and have been labelled as enabling, human capital formation, or investment approaches (Dingeldey, 2007; Eichhorst et al., 2008; Marchal \& Mechelen, 2017). In general, activation workers do not only "process" people by following administrative procedures, but implement policies that change people's behaviours (cf. Hasenfeld, 2010).

In addition to reconciling diverse policy elements, activation workers have to cater for the needs of an increasingly heterogeneous target group. This trend has been observed in many countries. Previous exemptions from work obligations for groups such as single parents, older people or those with health issues or disabilities have gradually been abolished in the course of policy reforms. Furthermore, additional groups of people may have to depend on social assistance benefits due to 
stricter eligibility criteria for sickness or disability schemes. As a result, citizens are highly diverse in terms of age, health, education and work experience, care responsibilities, or duration of their unemployment spell (Caswell, Kupka, et al., 2017). Activation workers have to react to fundamental problems that may go beyond unemployment, such as debts or health-related problems (Caswell, Larsen, van Berkel, \& Kupka, 2017).

Complex challenges and ambiguities in policies therefore concentrate in the practice of frontline workers who have to decide on solutions (Nothdurfter, 2016, p. 421) within permitted alternatives. Alongside the administrative aspects of the role which involves standardised bureaucratic routines, activation work demands professional responses to individual, sometimes challenging, situations and problems. This has inspired an academic debate around the nature of activation work, the question of whether it is an administrative function or provision of a professional service, or what an activation profession would actually entail (van Berkel \& van der Aa, 2012). Much of the debate centres around the concept of discretion. Discretion is exercised when a public officer has the power "to make a choice among possible courses of action and inaction" (Davis, as cited in Hupe and Hill, 2007, p. 281). It is, in addition to direct interactions with citizens, the distinguishing feature between traditional bureaucrats and street-level bureaucrats or professionals (Lipsky, 1980; van Berkel, van der Aa, \& Van Gestel, 2010). Recent studies indicate the continued opportunities for discretionary decision-making in the context of activation policies. However, some scholars point towards curtailments of the discretionary space in conjunction with increased standardisation of practices (Fuertes \& Lindsay, 2016; Jessen \& Tufte, 2014).

Given the diversity of policy instruments and citizens, the contested role of activation work as professional or administrative activity, and tensions between standardisation and individualisation, it is not surprising that practitioners themselves have varying conceptions of their work. These have been referred to as "frames of reference" (Eikenaar et al., 2016, p. 770) or role interpretations and framings of practice (Nothdurfter, 2016) that activation workers have vis-à-vis the recipient, the policies they implement, and their organisational context. In a Dutch case study, interviews with reintegration workers revealed substantial variations in their judgements (Eikenaar et al., 2016). The authors attributed this large variety to differences in the images of citizens that these frontline workers held. There were also differences in implicit rules or frames of reference on which they based their work. These frames were labelled as procedural, work-based, caring, learning, or facilitating. In a 
qualitative study in Austria, activation workers interpreted their roles in remarkably similar ways (Nothdurfter, 2016). More broadly, scholars have shown (activation) frontline workers' perceptions or social constructions of the recipients with whom they interact. Underpinning categories are recipients' perceived attitudes towards work or perceived deservingness (Altreiter \& Leibetseder, 2015; Buss, 2018; Dunn, 2013; Jilke \& Tummers, 2018; Rosenthal \& Peccei, 2006). Another distinction relates to the dilemma of whom to serve, i.e. the question of whether frontline workers are agents of the state or the citizen (Maynard-Moody \& Musheno, 2000).

Eikenaar et al. (2016) concluded that judgements depended too much on arbitrary decisions, which calls for investigation into the professional black box, particularly interactions between frames of reference, citizen characteristics, and institutional settings. One such example is a Norwegian study where 16 case files were scrutinised in combination with interviews with the responsible social workers (Solvang, 2017). Personalisation of services was mostly detached from citizens' characteristics or wishes, but depended on the social worker's dominant discretionary approach. A study based on a unique Suisse dataset that links jobseekers and their caseworkers concluded that jobseekers' employment chances were higher when caseworkers put less emphasis on satisfying jobseekers' wishes, but tended towards assigning programmes independent of those preferences (Behncke, Frölich, \& Lechner, 2010). The mechanism behind this, however, remained unexplained. Finally, based on a novel experimental approach, a study in Belgium concluded that roughly half of the variation in treatment decisions by activation workers could not be attributed to citizen characteristics (De Wilde \& Marchal, 2018). Activation workers' attitudes towards the welfare state and ideological beliefs were crucial, but a substantial amount of variation at the caseworker level could not be explained. Moreover, the study found no evidence in support of the identity hypothesis that caseworkers are more inclined to help recipients that are more similar to them, for example related to ethnicity or parenthood (cf. van Oorschot, Roosma, Meuleman, \& Reeskens, 2017). ${ }^{2}$ Finally, a study with 196 Dutch activation workers in 14 local welfare agencies looked more into what preceded activation workers' preferences, for example with regard to servicing and treating citizens, and investigated to what extent diverging preferences could be associated with the nature of activation workers' tasks and their educational background (van Berkel \& Knies, 2018). Aligning it with Eikenaar et al.'s (2016) frames of reference, the authors found some indicative evidence that workers with

2 In future work and with a larger sample, it would be interesting to explore this hypothesis. This chapter, however, focuses on the main effects of variables, also given the limited number of respondents as detailed in Section 5.5.3. 
a background in social administration focused more on procedures, whereas social workers tended towards a caring frame of reference. Activation workers with a degree in Personnel \& Labour, in turn, were more likely to demonstrate a work-based focus.

In summary, empirical evidence on activation frontline practices in European countries has established considerable variations in activation workers' judgements. There appear to be systematic links between activation workers' education and job design; activation workers' preferences or frames of reference, including citizen conceptions; citizen characteristics; and the assessment and treatment of citizens. All these studies provide interesting leverage points for further research, but are also limited in several respects. The majority of research designs do not allow us to make causal claims. Moreover, in interviews, caseworkers can rationalise their decisions in hindsight or provide socially desirable answers. In addition, activation workers might have cognitive biases so they are not even aware of some heuristics they implicitly use in their daily practice, which could lead to systematic errors. Studies based on administrative data, in turn, are limited to the exploration of a confined set of combinations of citizen characteristics as present in the sample. They therefore do not allow us to disentangle the effects of different factors that often are highly correlated in real life. Finally, as was also suggested by van Berkel and Knies (2018), there lacks a systematic investigation of the extent to which differences in workers' preferences result in different treatment decisions - everything else, such as organisational context or citizen characteristics, held constant. For that purpose, this chapter continues along the lines of De Wilde and Marchal (2018), who used a factorial survey experiment to investigate decision-making and confirmed the importance of beliefs and attitudes. Factorial survey experiments have so far rarely been employed to study activation workers' decision-making, but this method has more recently been applied to research questions on perceived deservingness (Buss, 2018; Jilke \& Tummers, 2018) or discrimination against ethnic minorities (Terum, Torsvik, \& Øverbye, 2018).

\subsection{Conceptual Framework}

The conceptual framework is based on Wallander and Molander's (2014) model of discretionary reasoning. Discretionary reasoning is defined as "the cognitive activity carried out by an agent when he or she is making judgements and decisions under conditions of indeterminacy" (Wallander \& Molander, 2014, p. 2). Activation work- 
ers are concerned with solving practical problems, that is, "problems about what to do" (Gauthier, 1963, p.1), and they have to justify their responses. This practical reasoning consists of three components (Toulmin, 1958): (i) data, a description of the situation; (ii) a claim/conclusion, a course of action or inaction; and (iii) the warrant, a norm of action that justifies the conclusion based on the data. In the context of professional work (see Figure 5.1), including activation, an additional step is added between the description of the situation and the conclusion. Starting from the pieces of information at hand, activation workers use identification rules to arrive at their diagnosis. For example, they assess citizens' job readiness or chances on the labour market. Activation workers subsequently decide on the basis of treatment rules what kind of treatment is required, that is, which specific (mix of) incentive-based and/or enabling policy instrument(s).

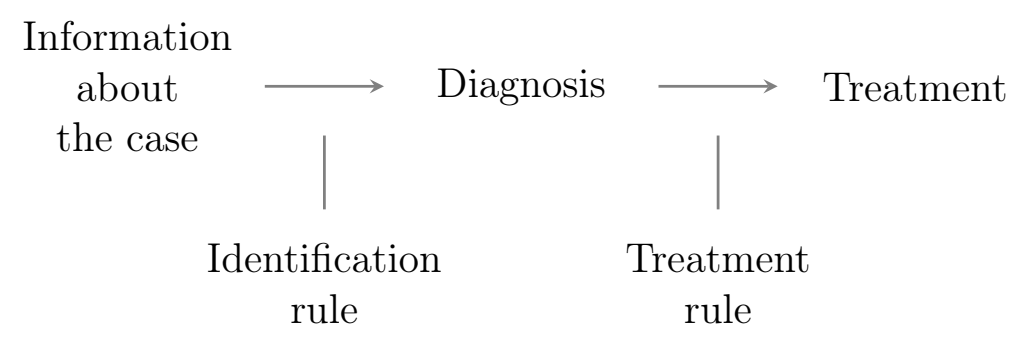

Figure 5.1: Components of discretionary reasoning in activation work Source: Author's own illustration based on Wallander and Molander (2014, p. 5).

Building on Rice's (2013) micro-institutionalist theory of policy implementation, factors that influence these judgements are organised at three levels: (1) citizen characteristics, (2) activation worker characteristics, and (3) the organisational context. In terms of citizen characteristics, previous studies, as well as key informants at the local Social Services office, identified age, sex, origin, language skills, health, household composition, education, motivation to work, or previous benefit receipt. On the side of the activation worker, relevant characteristics encompass demographics such as sex, age, education, work experience, parenthood, personal experiences with benefit receipt or unemployment (De Wilde \& Marchal, 2018; van Berkel \& Knies, 2018), as well as different frames of reference (Eikenaar et al., 2016; Nothdurfter, 2016). Finally, the activation worker/citizen interaction is embedded within an organisation with specific economic aspects impacting on these interactions (e.g. resources, budgets, contracting); as well as politics (autonomy, goals); culture and/or subcultures; and social relations (e.g. communication) (Rice, 2013).

Table 5.1 provides an overview of all hypotheses. To start with, literature on 
reemployment success and perceived deservingness of benefit recipients informs hypotheses on the links between citizen characteristics, the expected chances on the labour market and the use of demanding and enabling policy instruments. First, Wanberg, Hough, and Song (2002) presented a comprehensive model of factors related to reemployment success that included, among others, job seekers' human capital; reemployment constraints; job search intensity, clarity, and quality; and employer discrimination. In general, higher levels of human capital (level of education, language skills, and work experience) are expected to be associated with faster reemployment. Reemployment constraints refer to situational factors that can limit an individual's employment, such as care responsibilities, health issues, or debts. Job search intensity, clarity, and quality can be proxied by motivation to work. Discrimination of employers could be linked to jobseekers' origin. Previous benefit receipt might be interpreted by employers as a signal of lower skills or experience.

Second, literature on perceived deservingness suggests that the less in control somebody appears in a situation, the more rights and fewer requirements are expected to be granted (Buss, 2018). Factors beyond individual control refer to age, child care responsibilities, the reason for unemployment, and ethnicity (Buss, 2018), as well as health status and care responsibilities. Another factor is perceived effort (Buss, 2018; Jilke \& Tummers, 2018), as previous studies have shown that frontline workers' behaviour is influenced by their perceptions of whether the citizen is hard working, or appears to be free-riding on others. The link between the performance of citizens and the use of enabling instruments is less clear-cut (cf. Jilke \& Tummers, 2018). One line of argument is that street-level bureaucrats prioritise low performing citizens, as those are perceived as needy. Literature on 'creaming', in turn, argues that street-level bureaucrats focus on high-performing citizens, as they have the highest chances of success.

Third, a few studies looked at factors beyond citizen characteristics that affect activation workers' decision-making (De Wilde \& Marchal, 2018; Eikenaar et al., 2016). These studies emphasised the role of beliefs and convictions of activation workers in shaping activation practices, but there is limited evidence on the link between role interpretations and actual guidance or use of enabling instruments. Eikenaar et al. (2016) rather showed that different frames of reference have consequences for the content of guidance, and De Wilde and Marchal (2018) focused on sanctions. We therefore test whether there are indeed systematic links between variation in the use of instruments and activation workers' role interpretation, workplace characteristics, and individual characteristics. 
Table 5.1: Overview of hypotheses

(H1) Activation workers' assessment of citizens' chances on the labour market is higher for younger citizens, citizens who are Dutch or speak Dutch fluently, have higher levels of education, extensive work experience, no health issues, no care responsibilities, have not received a benefit previously, have no debts, and/or show a high motivation to find work than for older citizens, citizens with limited language skills, low levels of education, little work experience, bad health, care responsibilities, citizens who previously had a benefit, have debts and/or show no motivation to find work.

(H2) Activation workers are more likely to use demanding instruments for younger citizens, citizens with no health problems, no care responsibilities, and citizens who do not show willingness to find work than for older citizens or citizens with health problems, citizens with young children or who are providing informal care, and citizens who show a large motivation to find work.

(H3) Activation workers are more likely to use enabling instruments for citizens who show a high willingness to find work than for citizens who show a low willingness.

Activation workers are more likely to use enabling instruments for cit-

(H4a) izens who have greater chances on the labour market than for citizens who have lower chances on the labour market.

Activation workers are more likely to use enabling instruments for

(H4b) citizens who have lower chances on the labour market than for citizens who have greater chances on the labour market.

(H5) Variation in the use of instruments by activation workers is systematically related to activation workers' role interpretation.

(H6) Variation in the use of instruments by activation workers is systematically related to activation workers' work place characteristics.

(H7) Variation in the use of instruments by activation workers is systematically related to activation workers' individual characteristics. 


\subsection{Policy Context}

Since 2015, the legal framework that governs social assistance benefits is the Participation Act. The Participation Act carried forward the continuous strengthening of obligations for social assistance recipients since the mid-1990s. At present, municipalities can mandate virtually all social assistance recipients to engage in activities in return for their benefits (van Berkel, 2017b), which includes citizens that are very remote from the labour market. However, a study by the Dutch Ministry for Social Affairs and Employment concluded that many municipalities left it to their caseworkers to strike a balance between an approach that leans more towards sanctioning or supportive measures (Inspectie SZW, 2017). As clearly set out by the Ministry, resulting differences between caseworkers and municipalities contradicted its goal of a uniform application of the sanctioning regime. In general, the code of conduct for social assistance recipients includes obligations regarding the acceptance and maintenance of work; individual efforts to increase employability through acquisition and/or maintenance of skills, participation in reintegration activities, and appropriate behaviour and appearance; and signing up at temporary employment agencies upon request (Government of the Netherlands, 2016).

The (de jure) centralisation of a stricter sanctioning regime was accompanied by deregulation and decentralisation of reintegration activities. Similar to sanctioning practices, municipalities differ in what they want to achieve and how. A comparative study of five Dutch municipalities found that they differed with regard to their goals (e.g. increased participation, reintegration, or well-being), as well as their basic beliefs and the way they approached citizens (through coercion, motivation, or on a voluntary basis) (Kremer, van de Meer, \& Ham, 2017). In Maastricht, the city where this study was conducted, there are a number of policy instruments that activation workers can use individually or in combination. First of all, they can ask for a more detailed diagnosis of the situation and needs of a citizen, including referral to a doctor. In addition to the obligations spelt out above, activation workers can decide whether they impose an application requirement on citizens. In all cases, non-compliance with these obligations can be sanctioned. Furthermore, activation workers have a number of enabling policy instruments in their tool box. Job mediation encompasses application training or a specific project for citizens aged 45 and above. Instruments aiming at personal development include internships, training or language courses, or job coaching. Finally, there are further activities such as spending the day meaningfully or social activation. 
The increased heterogeneity of the target group described previously has also been observed in the Netherlands. While unemployed people are typically a vulnerable group on the labour market, citizens differ profoundly with regard to their educational attainment, work experience, health status, or family situation. The way in which this is reflected in the organisational context of frontline work differs (cf. van Berkel, 2017b). Municipalities choose different job designs, both in terms of tasks (combination of activation activities and benefit administration or not) and recipient groups (remote or very remote from the labour market, or mixed groups). Moreover, activation workers come from diverse educational backgrounds. In the study by van Berkel (2017b), employees with degrees in social work, social administration, and Personnel \& Labour, constituted roughly 60 per cent of the workforce, but the remaining caseworkers had other backgrounds. Professional associations of activation workers have only started to develop more recently and at this stage, they bring together people doing the same kind of job, rather than a community that shares expertise, professional standards and values (cf. van Berkel, 2017a).

\subsection{Research Method}

This section outlines the methodological framework that is based on Wallander and Molander (2014). After a brief introduction to factorial survey experiments, it specifies the measurement of dependent and independent variables, and explains the sampling procedure and analytical strategy.

\subsubsection{Factorial Survey Experiment}

In a factorial survey experiment, respondents are presented with fictitious descriptions of social objects (e.g. situations, persons), so-called vignettes. In this study, activation workers were presented with the description of a hypothetical citizen and were asked to assess the individual's labour market chances and what kind of activation instruments they would normally use. The values (levels) of attributes (dimensions) of these social objects were experimentally varied across the vignettes that were randomly assigned to activation workers. This means, the fictitious person was either a man or a woman, had either no work experience or extensive work experience, and so on. In contrast to conventional surveys, the systematic variation of values across the single descriptions and random assignment of the vignettes to activation workers allow us to estimate the impact of the experimental variations 
- the citizens characteristics - on the respondents' ratings, i.e. the treatment decisions of activation workers. This also means that activation workers had to weigh the different characteristics of citizens and arrive at an overall judgement.

In addition to the rating exercises, activation workers filled in a brief survey on characteristics of their workplace, their role understanding, and individual characteristics. Therefore, it is not only possible to estimate which judgement principles are shared by activation workers, but also to investigate to what extent there are subgroup differences. For example, variables that refer to the role understanding of activation workers can be included in the analysis to see whether differences in these frames are systematically linked to treatment decisions. Put differently, a social and an individual component of judgements are identified and the individual component further deconstructed to take into account subgroup variations (Rossi \& Anderson, 1982). An advantage of factorial survey experiments is that vignettes are presented in a multidimensional way. Several attributes, such as citizens' sex, age, or work experience, are manipulated at the same time. In this way, the effects of citizen characteristics that are in reality often highly correlated can be disentangled. In addition, the questioning becomes more subtle, social desirability bias is reduced (Auspurg \& Hinz, 2015), and tacit knowledge can be explored (Wallander \& Molander, 2014).

The random distribution of vignettes to respondents allows us to demonstrate causal relationships between variables and rule out competing explanations (cf. Auspurg \& Hinz, 2015). Some additional risks to the internal validity of factorial survey experiments can be dealt with at the design stage. For example, each vignette needs to be rated by several respondents to avoid vignette and respondent characteristics becoming confounded, and cognitive overload or misunderstandings of the task need to be avoided. What is more contested, however, is the external validity of the estimated effects. Critics question whether factors that explain hypothetical choices reflect real-life decision-making processes. Hainmüller, Hangartner, and Yamamoto (2015) showed that results from vignette and conjoint survey experiments matched very well with the relative importance of attributes of actual choices in the real world, as long as the sample was a probability sample of the target population and not a convenience sample. The fact that all respondents in this study are from the target population increases confidence in the results. At the same time, it is not possible to generalise across all activation workers in the Netherlands, as respondents only come from one organisation. Another point is that some combinations of citizen characteristics shown in vignettes might only rarely occur in the real world 
(cf. Wallander, 2009). Care was taken to define the dimensions in a way that no combinations were absolutely unrealistic, and respondents could indicate whether they were familiar with such a case in their daily work.

\subsubsection{Vignette and Survey Design}

Each caseworker received twelve vignettes describing a fictitious social assistance recipient and evaluated the labour market chances of this person, as well as the appropriate activation instruments. Table 5.2 summarises the citizen characteristics (dimensions) that are included and the levels at which they are measured. Furthermore, it shows how these characteristics are worded in the vignette. With eleven dimensions, the vignettes are more complex than usually recommended (seven dimensions plus/minus two) to avoid overburdening respondents (Auspurg \& Hinz, 2015), particularly when they are elderly, have lower levels of education, or are not familiar with the topic (Sauer, Auspurg, Hinz, \& Liebig, 2011). However, the level of complexity seemed appropriate for an expert group that is well-acquainted with the topic. The vignette read as follows (the randomly assigned characteristics appear in squared brackets):

A [24-year-old/35-year-old/50-year-old $]$ [man/woman $]$ [recently had/has never had] a social assistance benefit. He/she has [debts./no debts.] The man/woman is [ a native citizen./an immigrant and speaks Dutch fluently./an immigrant and speaks broken Dutch.] He/she lives [alone./alone with a child that is younger than five years./alone with a child that is older than five years. /with a partner and a child that is younger than five years./with a partner and a child that is older than five years.] $\mathrm{He} /$ she has [no health problems./physical health problems./mental health problems.] [He/she does currently not volunteer or provide informal care./Currently, he/she volunteers./Currently, he/she provides informal care.]

The man/woman has completed [primary education/secondary education/higher education][, but has only very limited work experience./and has extensive work experience.] He/she [shows great motivation to find work./shows little motivation to find work.] 
Table 5.2: Description of vignette dimensions, levels and wordings

\begin{tabular}{|c|c|c|}
\hline Dimension & & Wording \\
\hline \multirow[t]{4}{*}{ Age } & & A \\
\hline & 1 & 24-year-old ... \\
\hline & 2 & 35-year-old ... \\
\hline & 3 & 50-year-old ... \\
\hline \multirow[t]{2}{*}{ Sex } & 1 & $\ldots \operatorname{man} \ldots$ \\
\hline & 2 & ... woman ... \\
\hline \multirow[t]{3}{*}{ Previous benefit receipt } & 1 & ... recently had \\
\hline & 2 & ...has never had \\
\hline & & a social assistance benefit. \\
\hline \multirow[t]{3}{*}{ Debts } & & $\mathrm{He} /$ she has \\
\hline & 1 & debts \\
\hline & 2 & no debts. \\
\hline \multirow[t]{4}{*}{ Origin and language } & & The man/women is \\
\hline & 1 & a native citizen. \\
\hline & 2 & an immigrant and speaks Dutch fluently. \\
\hline & 3 & an immigrant and speaks broken Dutch. \\
\hline \multirow[t]{6}{*}{ Household composition } & & $\mathrm{He} /$ she lives \\
\hline & 1 & alone. \\
\hline & 2 & alone with a child that is younger than five years. \\
\hline & 3 & alone with a child that is older than five years. \\
\hline & 4 & with a partner and a child younger than five years. \\
\hline & 5 & with a partner and a child older than five years. \\
\hline \multirow[t]{4}{*}{ Health } & & $\mathrm{He} /$ she has \\
\hline & 1 & no health problems. \\
\hline & 2 & physical health problems. \\
\hline & 3 & mental health problems. \\
\hline \multirow[t]{4}{*}{ Participation } & 1 & He/she does currently not volunteer or provide \\
\hline & & informal care. \\
\hline & 2 & Currently, he/she volunteers. \\
\hline & 3 & Currently, he/she provides informal care. \\
\hline \multirow[t]{4}{*}{ Education } & & The man/women has completed \\
\hline & 1 & primary education ... \\
\hline & 2 & secondary education ... \\
\hline & 3 & higher education ... \\
\hline \multirow[t]{2}{*}{ Work experience } & 1 & $\ldots$, but has only very limited work experience. \\
\hline & 2 & $\ldots$ and has extensive work experience. \\
\hline \multirow[t]{3}{*}{ Motivation } & & $\mathrm{He} / \mathrm{she}$ \\
\hline & 1 & shows great motivation to find work. \\
\hline & 2 & shows little motivation to find work. \\
\hline
\end{tabular}


After each vignette, activation workers were asked whether they were familiar with such a case (the complete survey is shown in Appendix C). Subsequently, they had to assess how likely it was that the citizen would find paid employment within 12 months, rated on a scale from 0 to 100 . They were asked whether they would use an additional diagnostic tool (referral to a workplace for diagnosis or to an occupational physician/psychologist) and whether they would set an application requirement for this citizen, which represents a demanding instrument. The next three questions referred to enabling instruments, namely whether activation workers would use some type of job mediation instrument; a personal development instrument; and whether they would suggest other activities. ${ }^{3}$ In general, activation workers could decide to use a mix of instruments for the same citizen. In this study, the analysis focussed on whether a specific policy instruments was used for a citizen, but not on the number of policy instruments that were used or the mix of them.

The rating of vignettes was followed by questions on respondents' characteristics, including team affiliation, job design, work experience, role understanding and preferences, sex, age, parenthood, education, and personal experiences with unemployment or benefit receipt. Role interpretation was operationalised following the characterisation of the five frames of reference by Eikenaar et al. (2016). These frames are derived from what activation workers see as the "quintessence" (2016, p. 775 ) of their work and how this relates to their image of citizens. Workers in the procedural frame focus on the meticulous implementation of rules and regulations. A work-focused frame is described as promoting citizens' benefit independence and/or getting citizens (back) to work as the main objective. Providing citizens with the services they need is the core of a caring frame. Within a teaching frame, workers see the promotion of citizens' autonomous action as their main objective. Finally, a facilitating frame is operationalised as focussing on the provision of services that citizens want. Eikenaar et al. (2016) emphasised that workers might use different frames for different citizens. Therefore, a survey question was designed that allowed activation workers to indicate the relative importance of these five goals for their work (see Table 5.3). Participants had to distribute a total of 100 points across these objectives. The point allocation technique has several advantages. All dimensions

3 Activation workers could indicate the specific policy instrument that they would use (see pp. 208-209). The category of job mediation instruments subsumes application training and a project for older jobseekers. For personal development, these are internship/work experience placements; education/training/language classes; or training on the job. Further activities refer to social activation; sheltered employment; or activities to spend the day meaningfully. The answers were recoded into binary variables that indicate, for example, whether or not an instrument from the category of personal development instruments was chosen. 
that respondents rate are presented at the same time. Trade-offs between dimensions are made explicit, as a point that has been allocated to one dimension can no longer be allocated to another dimension. Furthermore, this approach acknowledges that frames of reference are not mutually exclusive but that caseworkers might pursue different objectives at the same time, yet to differing degrees.

Table 5.3: Survey measure of frames of reference

How important are the following objectives for your work?

In total, you can distribute 100 points across the following five objectives. The more important a certain objective is for your work, the more points you allocate to it. It is also possible to allocate the same amount of points to certain objectives, or to allocate no points at all to an objective.

Implementing rules and regulations meticulously:

Promoting citizens' benefit independence/getting citizens (back)

to work:

Providing citizens with the services they need:

Promoting citizens' autonomous action:

Providing citizens with the services they want:

\subsubsection{Sample Size and Sampling}

The combinations of the eleven citizen characteristics with two to five levels respectively resulted in a universe of 38,880 vignettes $\left(2^{5} \cdot 3^{5} \cdot 5\right)$. Since obviously not all of these vignettes could be presented to activation workers, a sample of vignettes was drawn. Taking into account trade-offs between feasibility and statistical efficiency, the necessary sample size is decided based on number of interrelated choices (Auspurg \& Hinz, 2015): These include (i) the total number of vignettes; (ii) the number of vignettes that is shown to each respondent; (iii) and the number of respondents who evaluate the same vignette deck.

The following considerations guided these choices. First, since the rating of vignettes is cognitively demanding, vignette decks should not become too large in order to avoid fatigue effects and inconsistent responses. Sauer et al. (2011) recommended that respondents should not rate more than 20 vignettes with fewer than 
12 dimensions. In this study, each respondent was asked to judge twelve vignettes. Since the vignettes were already quite complex and eight questions had to be answered after each vignette, a higher number of vignettes per respondent did not seem desirable even in light of the fact that respondents are experts in this topic. Second, the population of activation workers was limited within the studied organisation. At the outset, it was estimated that approximately 60 employees would fit the inclusion criteria. It is recommended that each vignette (deck) should be judged by at least five respondents (Auspurg \& Hinz, 2015). If a vignette is rated by only a single respondent, personal characteristics of the respondent and the vignette become confounded. With ten decks, this minimum could be reached.

The third consideration was the level of statistical efficiency that could be achieved with different sample sizes. Until recently, many studies used random samples (Dülmer, 2007, 2016). However, especially with smaller samples, different dimensions can be highly correlated and levels of dimensions unbalanced by chance, ${ }^{4}$ which results into information loss as compared to a sample where dimensions are uncorrelated (orthogonality) and all levels of dimensions occur with the same frequency (balance). The parameter estimates are not as precise as they could be since the variance and covariance of coefficients are not minimised. Commonly, statistical information is measured with the Fisher information matrix, which forms the basis for many measures of the goodness of an experimental design, the so-called design efficiency (Auspurg \& Hinz, 2015). Among measures of design efficiency, D-efficiency is the most prominent. D-efficiency is a standardised measure that takes into account both orthogonality and balance and optimises these criteria (Dülmer, 2007). ${ }^{5}$ The measure ranges from 0 to 100 . Values above 90 are usually considered adequate for most research purposes in the social sciences (Auspurg \& Hinz, 2015).

The design search was implemented with the package AlgDesign in R (Wheeler, 2004b). The sample of vignettes was blocked into decks using the same package's block option (Wheeler, 2004a). Since D-efficiency does not necessarily increase with larger sample sizes, a large number of different designs was compared to find the design that satisfied the considerations above in a good way. Based on an iterative process, it was decided to draw a sample of 120 vignettes. These 120 vignettes

4 In the universe of all vignettes, the levels of all dimensions occur with the same frequency, which does not need to be the case when a random sample is drawn.

5 D-efficiency is calculated in the following way: D-ef ficiency $=100 \cdot\left(\frac{1}{N_{D}} \cdot\left|X^{\prime} \cdot X\right|^{\left(\frac{1}{p}\right)}\right)$, where $N_{D}$ denotes the set size of the design, $\left|X^{\prime} \cdot X\right|$ is the information matrix of the vignette variables including the intercept, and $p$ refers to the number of $\beta$ s including the intercept that will be estimated (Dülmer, 2016, pp. 316-317). 
are organised in 10 decks à 12 vignettes. The final sample reached a D-efficiency of 91.4. The vignette sample was balanced and most dimensions were completely uncorrelated. In the few cases in which the dimensions were correlated, the strongest correlation did not exceed $r=|0.064|$ and all other correlations were marginal.

\subsubsection{Analytical Strategy}

The data analysis aimed to identify systematic correlation structures between caseworkers' judgements and the citizen characteristics included in the vignettes, as well as the characteristics of caseworkers that were collected in the survey. Since every activation worker judged several vignettes, the hierarchical data structure needed to be taken into account. This is reflected by including an additional error component. For an outcome measured on an interval scale ( $Y$ is the perceived probability of finding a job within twelve months), the following model is used:

$$
Y_{i j}=\beta_{0}+\beta_{1} X_{i j 1}+\beta_{2} X_{i j 2}+\cdots+\beta_{p} X_{i j p}+\gamma_{1} Z_{j 1}+\gamma_{2} Z_{j 2}+\cdots+\gamma_{q} Z_{j q}+u_{j}+\epsilon_{i j}
$$

where $i$ indexes the citizen and $j$ the activation worker, $i=1, \ldots, n_{d}$ and $j=$ $1, \ldots, n_{r}, \beta_{1}$ to $\beta_{p}$ denote the coefficients for the citizen characteristics ( $X$ would be citizens' sex, age, etc.) and $\gamma_{1}$ to $\gamma_{q}$ the coefficients for activation worker characteristics ( $Z$ refers to sex, age, workplace characteristics, etc.). The variance of the outcome $Y_{i j}$ can be decomposed into the variance between activation workers $u_{j}$ and the variance within activation workers (and between citizens) $\epsilon_{i j}$.

For binary outcome variables (the log-odds of opting for additional diagnosis or for an application requirement; and the log-odds of using job mediation; personal development; or other activities), the model is written as follows:

$\log \left(\frac{\pi_{i j}}{1-\pi_{i j}}\right)=\beta_{0}+\beta_{1} X_{i j 1}+\beta_{2} X_{i j 2}+\cdots+\beta_{p} X_{i j p}+\gamma_{1} Z_{j 1}+\gamma_{2} Z_{j 2}+\cdots+\gamma_{q} Z_{j q}+u_{j}+\epsilon_{i j}$

which can be reorganised to obtain an expression for the response probability $\pi_{i j}$ :

$\pi_{i j}=\frac{\exp \left(\beta_{0}+\beta_{1} X_{i j 1}+\beta_{2} X_{i j 2}+\cdots+\beta_{p} X_{i j p}+\gamma_{1} Z_{j 1}+\gamma_{2} Z_{j 2}+\cdots+\gamma_{q} Z_{j q}+u_{j}+\epsilon_{i j}\right)}{1+\exp \left(\beta_{0}+\beta_{1} X_{i j 1}+\beta_{2} X_{i j 2}+\cdots+\beta_{p} X_{i j p}+\gamma_{1} Z_{j 1}+\gamma_{2} Z_{j 2}+\cdots+\gamma_{q} Z_{j q}+u_{j}+\epsilon_{i j}\right)}$ 
To explicitly address the multilevel structure of the error term, multilevel regression models were used that take into account different thresholds for individual respondents (i.e., random intercepts: the sum of the intercept and the first error component) of the outcomes. In addition to these random intercept models, it would also be possible to take into account individual variation in the slope (random slope models). The results presented in the next section are based on more parsimonious random intercept models, as random slope models require strong additional assumptions on the distribution of the variance components (Auspurg \& Hinz, 2015). Above all, there should be sound theoretical consideration of why the effects of citizen characteristics should differ randomly across caseworkers, which is not part of the conceptual model outlined in the previous section. ${ }^{6}$

The models were built up in several steps. First, a null model was estimated without explanatory variables to determine the unexplained variance at the level of the caseworker and the level of citizens. In the next step, citizen characteristics were added. This model investigated the link between citizen characteristics and activation workers' judgements. In the following steps, groups of variables pertaining to activation workers were included in the following sequence: (1) Frames of reference; (2) workplace characteristics (team membership, type of target group, job design, and caseload); and (3) socio-economic characteristics of the caseworker, as well as their familiarity with the case and their previous assessment of the respective citizen's labour market chances. This approach allowed us to determine how much of the unexplained variance was explained by frames of reference, workplace characteristics, and individual characteristics respectively. Furthermore, dummy variables for each vignette deck were included in order to control for systematic differences depending on which deck a respondent judged. The presentation and interpretation of results refer to the final model that includes all variables.

\subsection{Discussion of Results}

The link to the online survey was distributed to all 106 caseworkers at the Social Services office Maastricht Heuvelland who have direct contact with citizens within the framework of the Participation Act (as of June 2018). By December 2018, 53 participants had completed the survey. Due to the level of non-response, the sample might not be representative of the population of caseworkers in Maastricht. Table

6 Nonetheless, several models that allowed for different slopes across caseworkers were tested, but there was no strong evidence that the effects of coefficients varied across caseworkers. 
5.4 summarises their characteristics. The typical respondent is a 45-year old woman with no foreign background and at least one child. The educational background of participants is diverse. Social administration and social work are the most common profiles, but still more than one third of the participants have other backgrounds such as economics, law, or more specialised training such as reintegration or job mediation. Participants have on average 16 years of work experience, yet this differs widely as well. Notably, every second activation worker had the experience of being unemployed for more than six months or receiving a social assistance benefit, or at least knows somebody with such an experience within their close circles.

Table 5.5 displays respondents' workplace characteristics. Respondents in the intake team (eleven per cent) conduct the initial meetings with persons who apply for social assistance and decide on first steps towards reintegration. After this intake phase, social assistance recipients who have not yet found a job become so-called 'active files' and are handled by persons in this team (43 per cent of respondents). Other teams are the youth team (13 per cent) that specifically caters for the needs of younger persons (up to the age of 27), including their first meetings at the Social Services office, and a team of specialists (23 per cent), for example regarding reintegration activities such as participation placements. Approximately one third of the respondents reported that they had more than one major task. Most commonly, caseworkers conduct both intake meetings and manage active files. The majority of respondents does not work with a specific target group in terms of their labour market chances. The average working time is 36 hours per week. Approximately every third respondent is employed part-time. The average caseload, seen in relation to the number of weekly working hours, is two cases per hour.

Regarding workers' role understandings, workers attach, on average, the greatest importance to enhancing citizens' autonomy (32.1 points), as well as to moving citizens back into work (23.3 points). The provision of services that citizens need is the next most important objective (20.5 points). Focus on procedures and facilitation of services play comparatively minor roles (13.1 and 10.9 points respectively). More interesting than averages, however, are two aspects illustrated in Figure 5.2. First, caseworkers differ profoundly regarding the relative importance of different frames, as captured by the large spread of the distributions in the left plot. Second, as shown in the right plot, there are differences of these configurations across teams. Whereas respondents in the intake team tend to focus more on procedures and trajectories into work, the caring and learning frames are more important for the role understanding of other teams. This points to subcultures within teams. 
Table 5.4: Activation worker characteristics (in per cent)

\begin{tabular}{lr}
\hline Age (in years) & $45.4(10.5)$ \\
Male & 39.6 \\
Dutch & 100.0 \\
Foreign background & 7.6 \\
Parent & 75.5 \\
Personal experience with unemployment & 49.0 \\
Education & \\
$\quad$ Social administration & 45.3 \\
$\quad$ Social work & 15.1 \\
$\quad$ Personnel and labour & 9.4 \\
$\quad$ Other & 35.9 \\
Level of education & \\
$\quad$ Higher professional education & 84.9 \\
$\quad$ University & 15.1 \\
Work experience (in years) & $16.0(9.5)$ \\
\hline \hline
\end{tabular}

Source: Author's own calculations.

Notes: The percentages for education do not add up to 100 per cent since three respondents followed more than one educational trajectory. For age in years and years of work experience, the standard deviation is given in parentheses. $N=53$.

Table 5.5: Job characteristics of activation workers (in per cent)

\begin{tabular}{lc}
\hline Team membership & \\
$\quad$ Intake & 11.3 \\
Active files & 43.4 \\
Specialist & 20.8 \\
Youth team & 13.2 \\
Other & 11.3 \\
Main task & \\
$\quad$ Intake & 26.4 \\
Support/assistance & 84.9 \\
Specialist & 22.6 \\
Other & 11.3 \\
Integrated job design & 37.7 \\
Mixed target group & 62.3 \\
Working hours per week & $35.5(5.7)$ \\
Caseload (per hour) & $2.0(1.0)$ \\
\hline \hline
\end{tabular}

Source: Author's own calculations.

Notes: The percentages for main task do not add up to a 100 per cent since several respondents indicated more than one major task. For caseload per hour, the standard deviation is given in parentheses. $N=53$. 

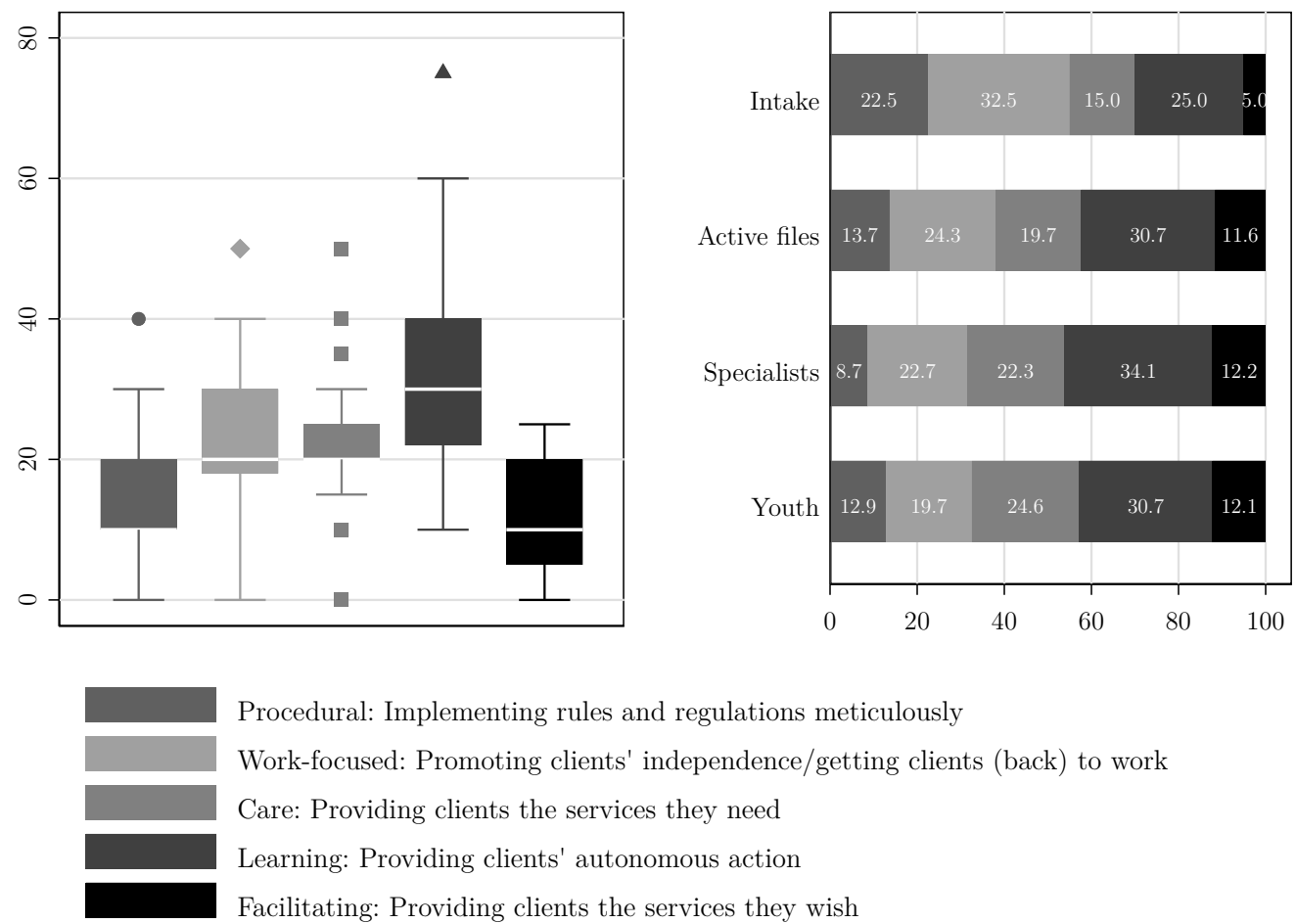

Procedural: Implementing rules and regulations meticulously

Work-focused: Promoting clients' independence/getting clients (back) to work

Care: Providing clients the services they need

Learning: Providing clients' autonomous action

Facilitating: Providing clients the services they wish

Figure 5.2: Frames of reference: The relative importance of different work objectives, overall distribution and by team membership

Source: Author's own calculations.

Notes: $N=53$. In the left plot, the distribution is presented as box plot. The box represents the middle 50 per cent of values. The middle line is the median value. The line below and above the box represents the range for the bottom and top 25 per cent of respondents respectively. The dots indicate outside values. In the right plot, the stacked bar shows the relative importance of each frame of reference, as average across all members of the respective team.

Table 5.6: Correlations between different frames of reference

\begin{tabular}{ccccc}
\hline \hline $\begin{array}{c}\text { Procedural } \\
-0.076\end{array}$ & & & & \\
$(0.589)$ & Work & & & \\
\cline { 1 - 2 }-0.265 & -0.407 & & & \\
$(0.055)$ & $(0.002)$ & Care & & \\
\hline-0.377 & -0.320 & -0.320 & Learn $/$ change & \\
$(0.005)$ & $(0.019)$ & $(0.020)$ & -0.397 & Facilitate \\
\hline-0.087 & -0.324 & 0.207 & $(0.003)$ & \\
$(0.534)$ & $(0.018)$ & $(0.137)$ & & \\
\hline \hline
\end{tabular}

Source: Author's own calculations.

Notes: $N=53$. The first number of each pair indicates the Pearson's correlation coefficient and the second number given in brackets the $p$-value. 
Furthermore, when looking at correlations between different frames (Table 5.6), the largest trade-off exists between the caring and the work-focused frames. The more importance a caseworker attaches to moving a citizen into work, the less emphasis is put on promoting autonomous action (and vice versa). Another trade-off exists between ideas of promoting citizens' autonomous action and the provision of services that citizens want; as well as between a focus on procedures and strengthening autonomy.

All vignette decks were judged by at least five caseworkers, except for the fourth (four) and ninth (three caseworkers) deck. The analysis is based on 630 vignette evaluations. Across these vignettes, all citizen characteristics were balanced. Correlations between the variables were either insignificant or very small and their absolute magnitude did not exceed $r=|0.115|$. Table 5.7 and Figure 5.3 display the outcomes of the vignette evaluations. Activation workers were normally familiar with the type of cases presented to them. On average, the estimated likelihood that a citizen would find work within 12 months was 54.9 per cent. The histogram shows a rounding tendency towards multiples of ten (i.e., 20 per cent, 30 per cent, and so on) that appears as little spikes, yet overall, the outcome follows a normal distribution. In three out of four cases, workers would direct the citizen to write applications and in two thirds of the cases, activation workers would opt for an additional diagnostic instrument. In terms of enabling activities, the most frequently chosen options were instruments for personal development, followed by job mediation and further activities. The presentation of results starts with the extent to which activation workers share norms based on citizen characteristics. Subsequently, the focus is on the variation in the use of instruments and the extent to which these are systematically linked to frames of reference, workplace characteristics, and workers' individual characteristics.

Table 5.7: Vignette evaluations (demanding and enabling instruments, in per cent)

\begin{tabular}{ll}
\hline \hline Outcome variable & \\
\hline Familiarity with vignette & 81.3 \\
Application requirement & 78.1 \\
Further diagnosis & 67.2 \\
Job mediation & 63.7 \\
Personal development & 84.5 \\
Activities & 59.0 \\
\hline \hline
\end{tabular}

Source and notes: Author's own calculations. $N=630$. 


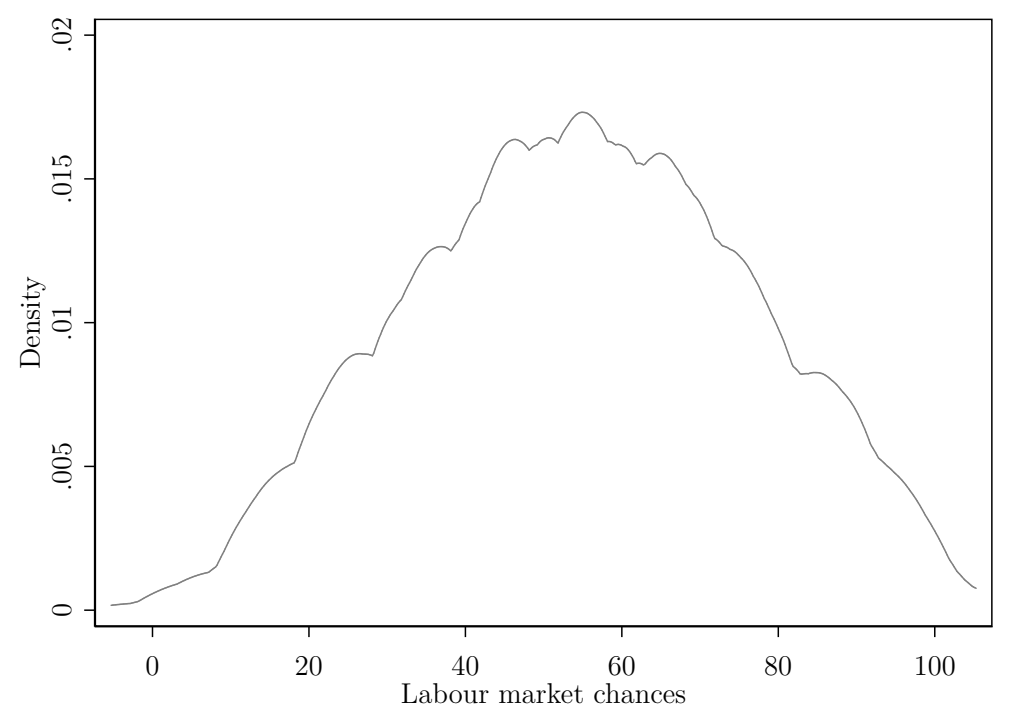

Figure 5.3: Vignette evaluations (labour market chances)

Source and notes: Author's own calculations. $N=630$.

First, Figure $5.4^{7}$ shows that nearly all citizen characteristics that were included had a significant effect on the perceived probability of finding work within twelve months. According to caseworkers' judgement, and everything else being equal, the likelihood of finding work reduces as citizens get older, when they have debts, speak only broken Dutch, when there is a young child in the household, and, most strongly, when citizens report physical or mental health problems. On the positive side are higher levels of educational attainment, previous work experience, a strong work commitment and working as a volunteer. A surprising result is that caseworkers, ceteris paribus, expect that men are 2.4 percentage points more likely to find a job within 12 months. This might be an example of an unconscious bias that caseworkers themselves are not aware of.

Second, caseworkers shared fewer common warrants based on citizen characteristics when it came to the question of whether an application requirement should be imposed. Factors on which respondents tended to agree were that an application requirement was less adequate for persons with physical or mental health problems, but more expedient for individuals with, according to their assessment, greater chances on the labour market (Figure 5.5). This supports the second hypothesis that mental or physical impairments would make it less likely that caseworkers imposed requirements on citizens. Instead, the odds of using an additional diagnostic tool were

$7 \quad$ The detailed estimation results for all models are shown in Appendix D. 
considerably higher for persons with physical or mental health problems.

Third, the hypothesis that activation workers would be more likely to use enabling instruments for citizens who show a high willingness to find work than for citizens who show low motivation is rejected. The coefficient of attitude towards work was not significant with regard to the use of job mediation or personal development instruments. Fourth, the competing hypotheses were tested on whether workers were more likely to use enabling instruments for citizens who have greater chances on the labour market than for those citizens who have lower chances, or vice versa. The results showed that this depends on the type of activity. The odds of using job mediation or an instrument for personal development were higher for persons that are presumably more likely to find a job in the short term, whereas the odds of assigning further activities were lower (Figure 5.6 to Figure 5.8). Hence, instruments that are more directly linked to increasing individuals' employability tend to be prioritised towards recipients that show more reintegration potential in the short run, supporting the 'creaming' hypothesis. Further activities, such as social activation, tend to be used for citizens whose labour market chances appear to be lower.

Fifth, in order to have a closer look at the link between frames of reference and the vignette ratings, Figure 5.9 to Figure 5.13 zoom in on the odds ratios for the variables that indicate the different frames of reference. The hypothesis that the variation in the use of policy instruments is systematically linked to frames of reference is confirmed. With regard to all instruments, the effect of at least one frame of reference was statistically significant. Furthermore, Table 5.8 reports the variance partition coefficients - the share of between caseworker variance in the total variance - for all models. It also shows how the inclusion of additional respondent characteristics changes them. In the null model, the share of between caseworker variance in the total variance was 20 per cent for the rating of labour market chances. It was substantially higher (between 25 to nearly 50 per cent) when it came to the use of enabling instruments. The inclusion of frames of reference decreased the unexplained variance in all models. 


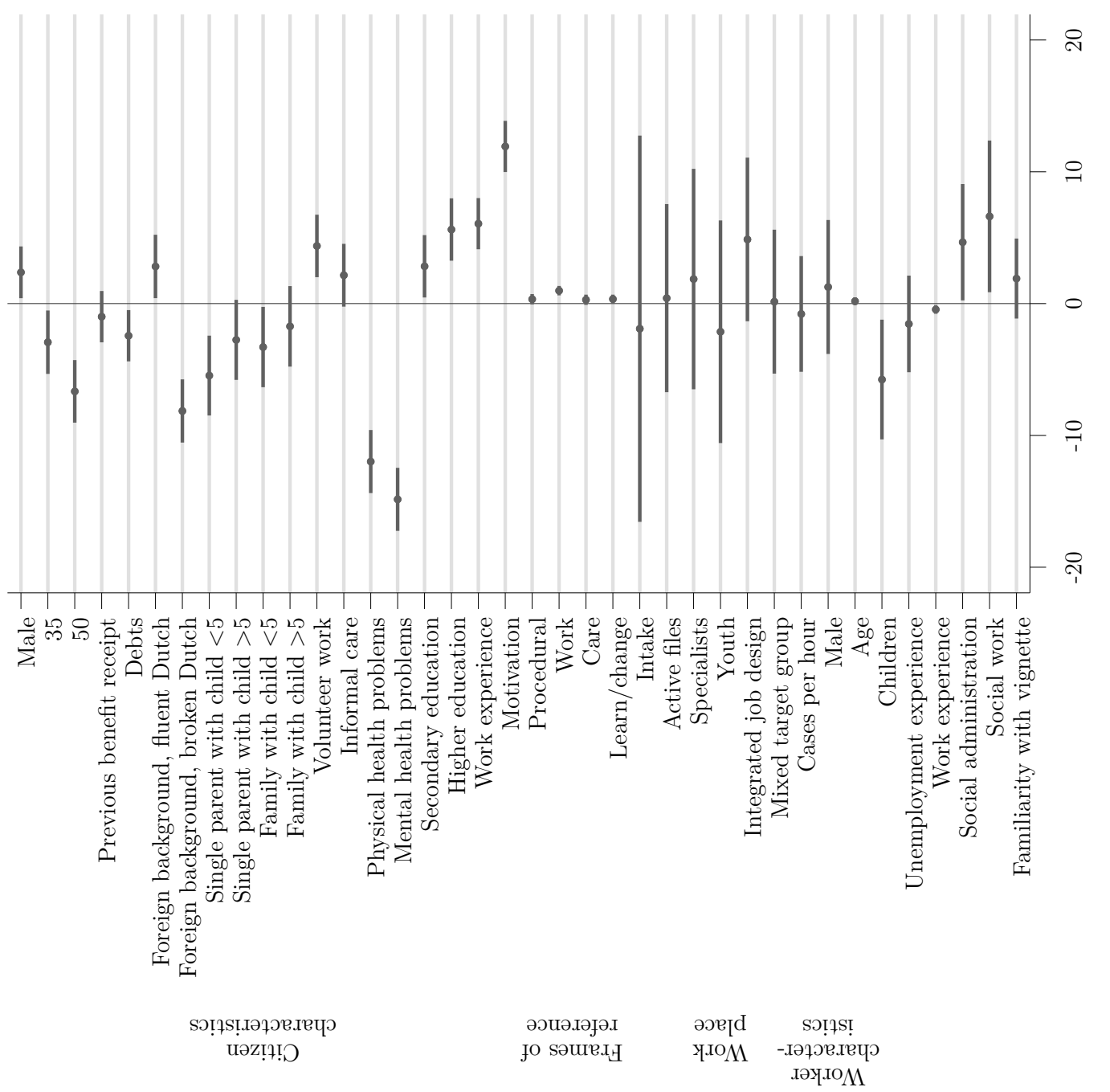




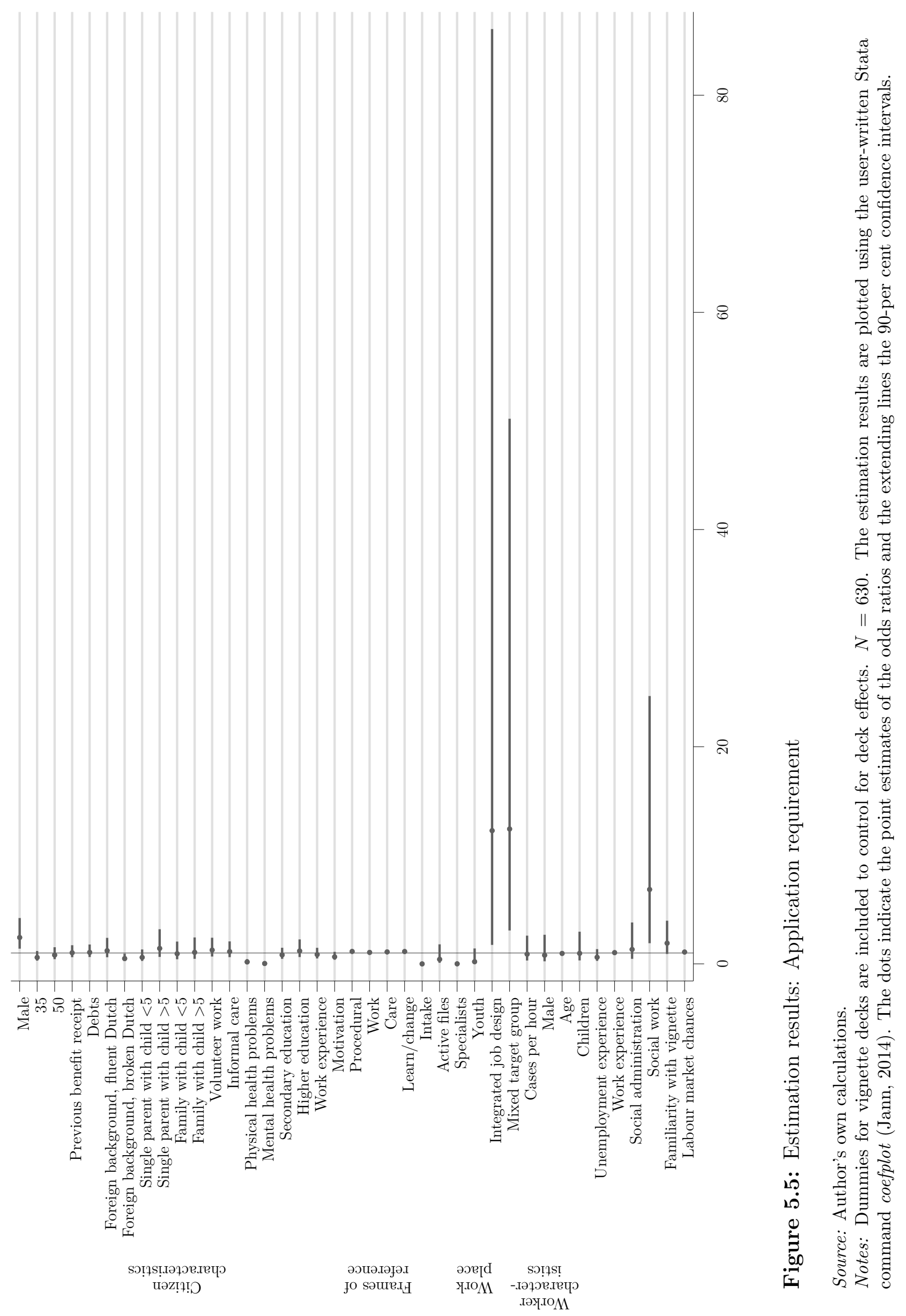




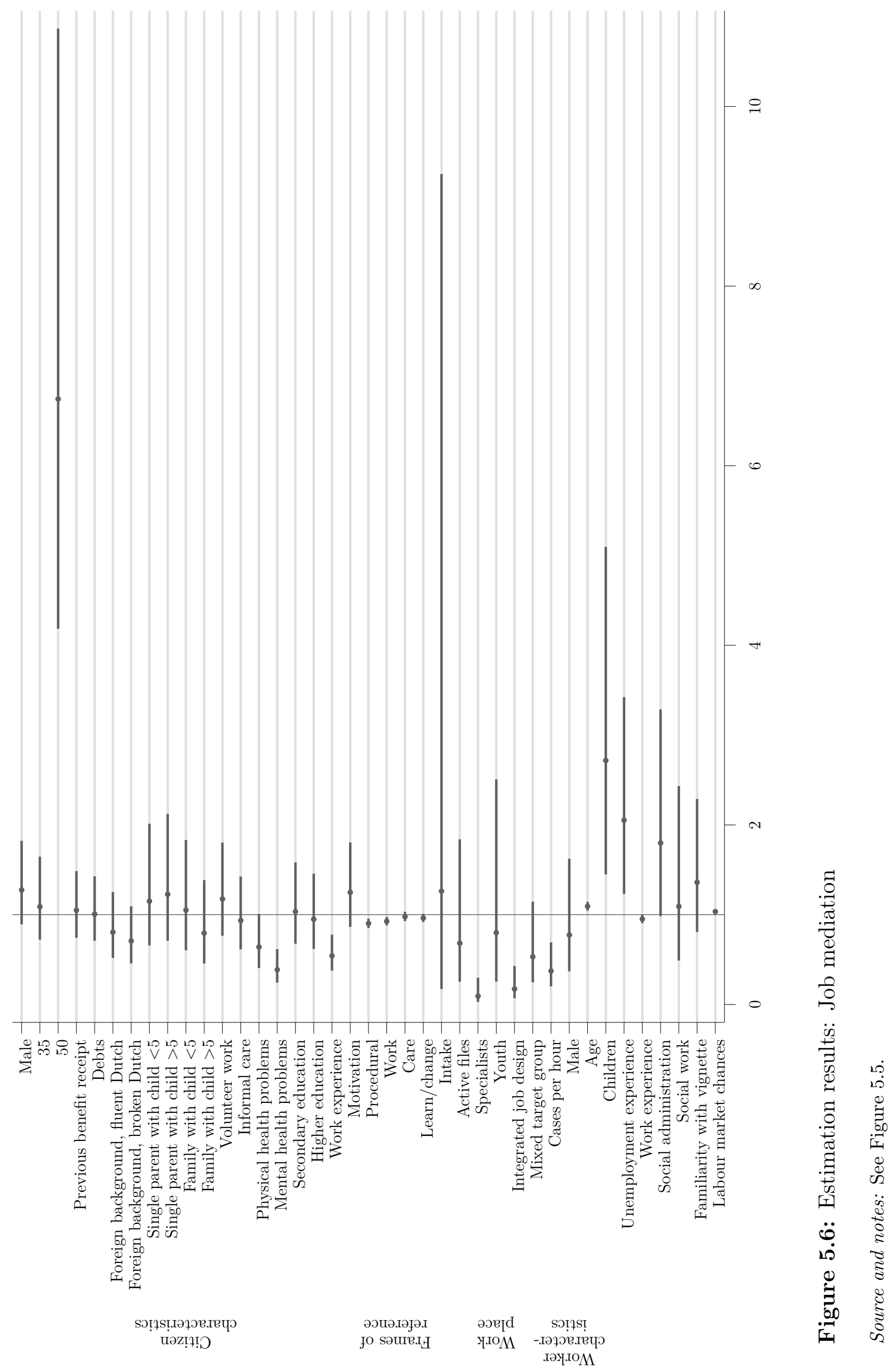




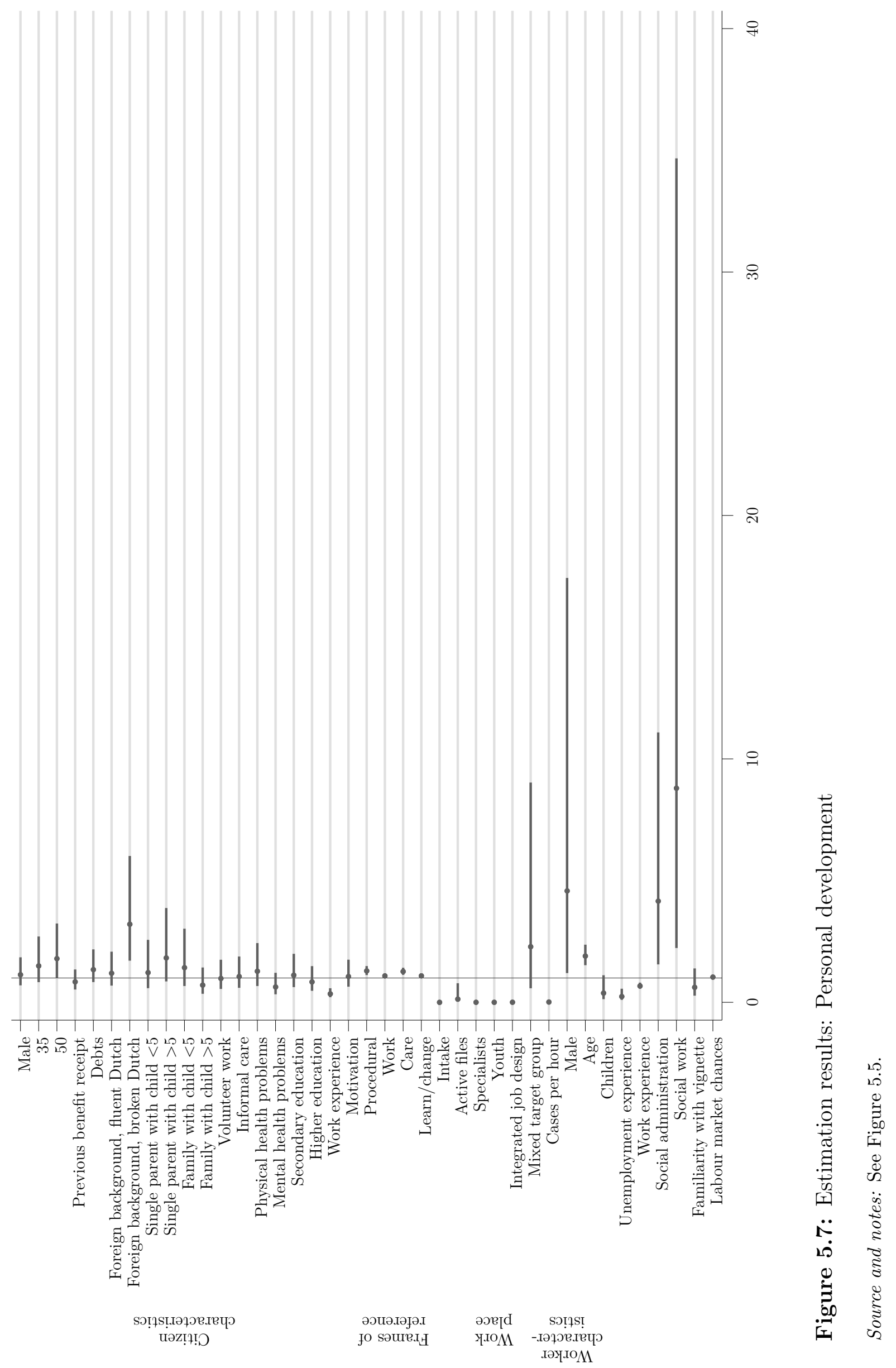




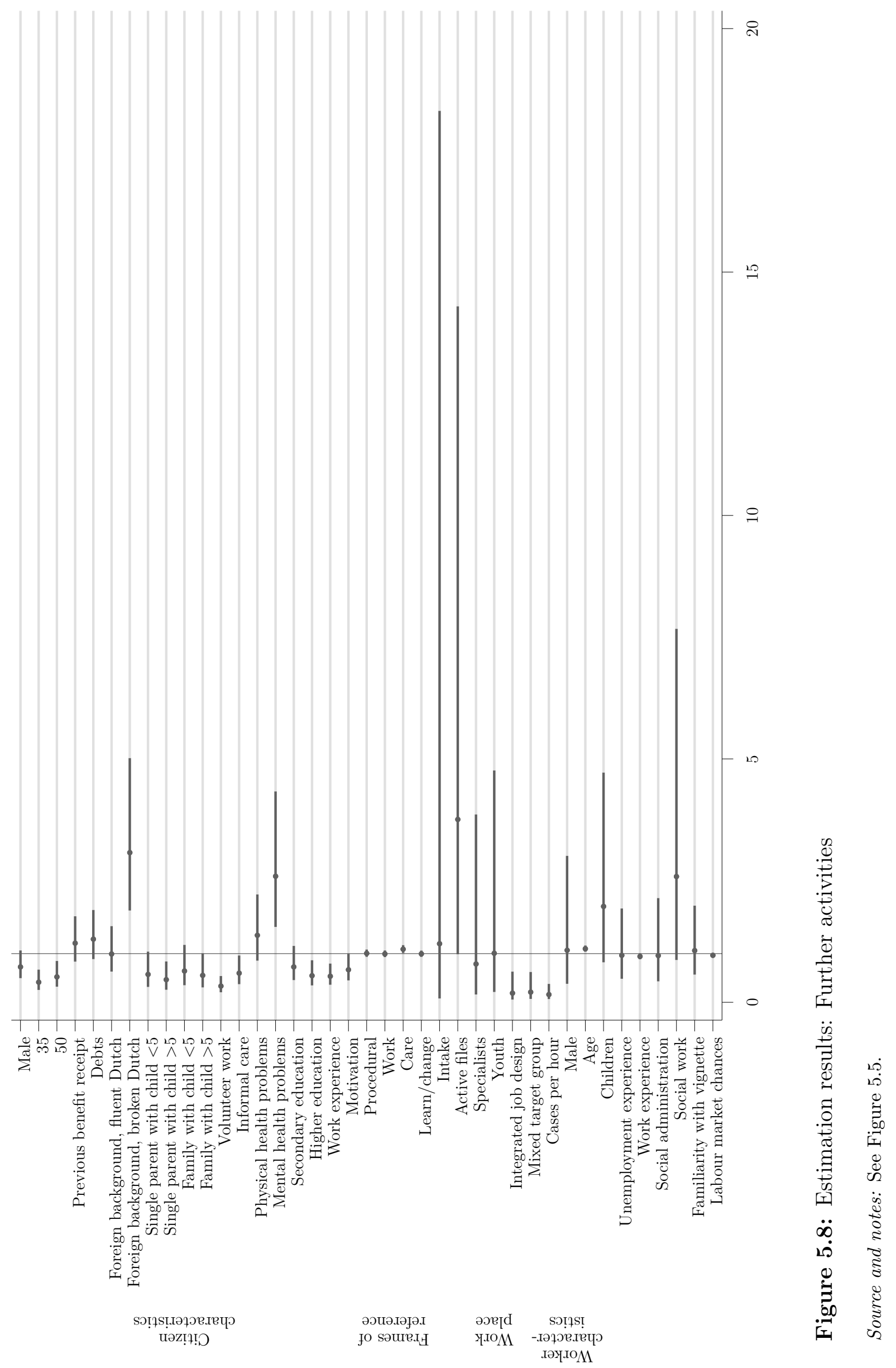




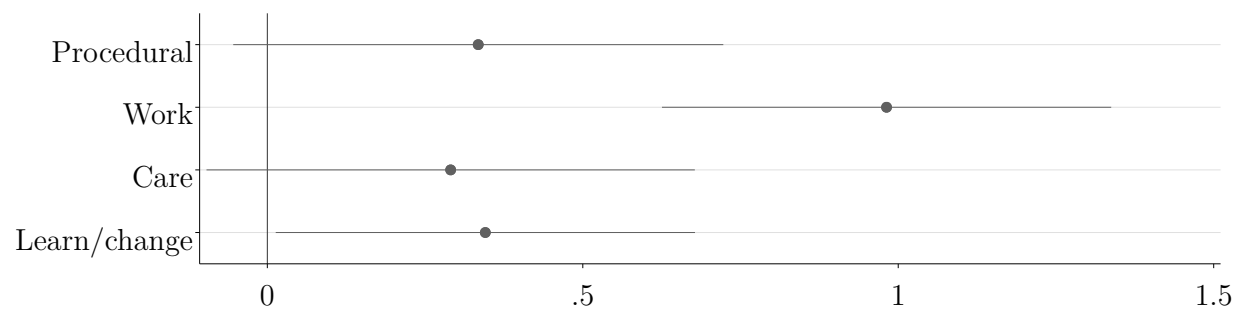

Figure 5.9: Detailed view: Effects of frames of reference on likelihood of finding work within 12 months

Source and notes: See Figure 5.4.

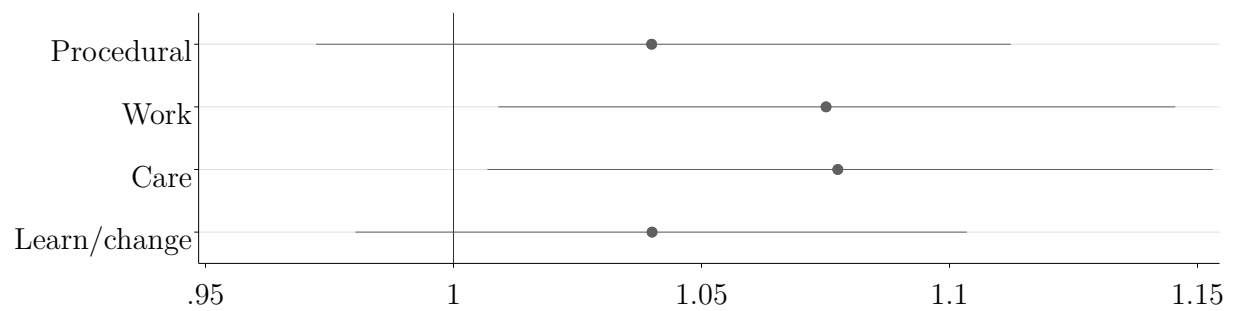

Figure 5.10: Detailed view: Effects of frames of reference on application requirement

Source and notes: See Figure 5.5.

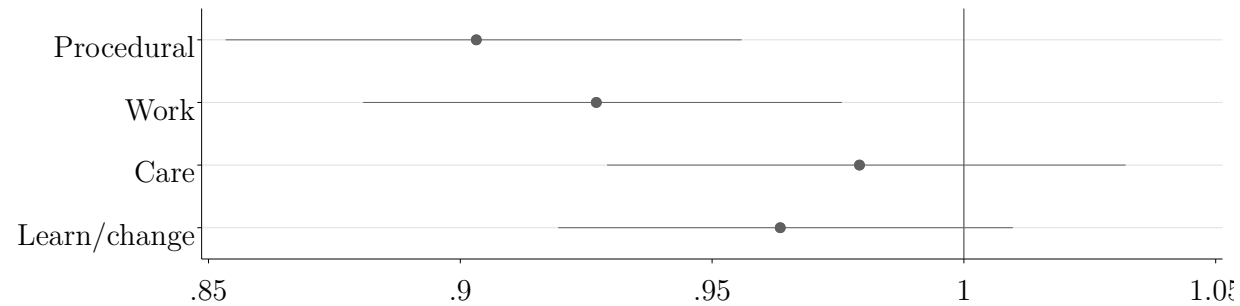

Figure 5.11: Detailed view: Effects of frames of reference on job mediation

Source and notes: See Figure 5.5.

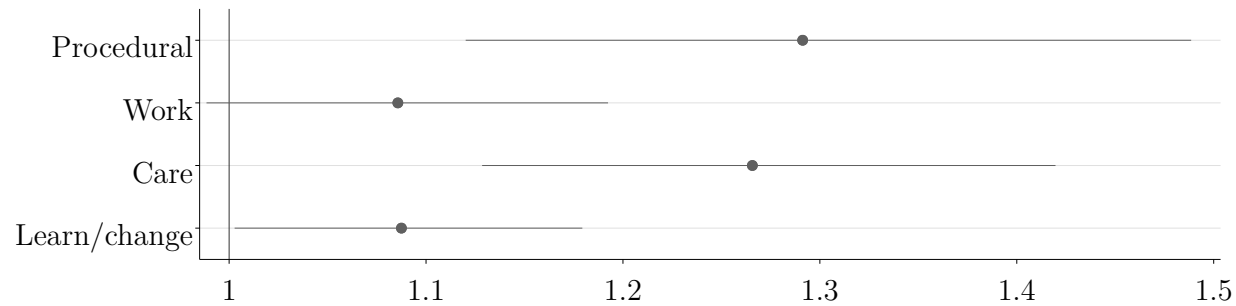

Figure 5.12: Detailed view: Effects of frames of reference on personal development Source and notes: See Figure 5.5. 


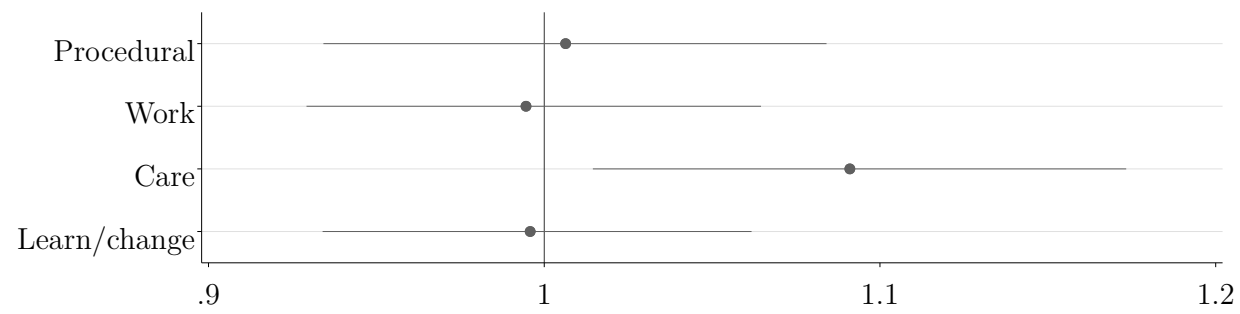

Figure 5.13: Detailed view: Effects of frames of reference on further activities

Source and notes: See Figure 5.5.

The results indicate some more refined relationships between the variation in the use of policy instruments and different frames of reference. With regard to the assessment of labour market chances, the null hypothesis that the coefficients of the work-focused and the care-focused frame are equal was rejected $\left(\chi^{2}(1)=\right.$ $15.94, p=0.0001)$. A one-unit increase of the points allocated to the work-focused frame is associated with a nearly one percentage point increase in the estimated likelihood of finding work within twelve months, everything else being equal. In the sample, the 50 per cent of respondents in the middle of the distribution allocated between 18 and 30 points to the work-focused frame (see left plot of Figure 5.2). In a thought experiment, it is possible to estimate what effect it would have if a caseworker who tends towards a work-focused frame (30 points) moves towards a frame that places less relative importance on this objective (18 points). Assuming at the same time that this change is compensated by a stronger emphasis on a carefocused frame (increasing from 18 to 30 points), keeping all other variables equal and at their means, and using the fixed part of the model only, the estimated likelihood of finding work within 12 months changes from 59.5 per cent to 51.2 per cent. ${ }^{8}$

Furthermore, activation workers who tended towards a caring frame were more likely to employ a job mediation instrument than activation workers who were inclined towards a work-focused frame. Again, the null hypothesis that the coefficients of the work-focused and the care-focused frame are equal was rejected $\left(\chi^{2}(1)=4.91, p=0.0266\right)$. Assuming that everything else is held equal and that all other variables are kept at their means, except for changing from a more workfocused to a more care-focused frame (from 30 points to 18 points and vice versa), the predicted probability of using job mediation as an enabling instrument increases by nearly 13 percentage points (from 65.3 per cent to 78.3 per cent).

8 It is also possible to keep all other variables equal and at their medians. In this case, the estimated likelihood changes from 79.9 per cent to 71.6 per cent. 
Table 5.8: Variance partition coefficients

\begin{tabular}{|c|c|c|c|c|}
\hline & $\begin{array}{r}\text { Between- } \\
\text { caseworker } \\
\text { variance } \\
(\text { level 2) }\end{array}$ & $\begin{array}{r}\text { Within- } \\
\text { caseworker, } \\
\text { between- } \\
\text { citizen } \\
\text { variance } \\
(\text { level 1) }\end{array}$ & $\begin{array}{r}\text { Total } \\
\text { variance }\end{array}$ & VPC \\
\hline \multicolumn{5}{|l|}{ Labour market chances } \\
\hline Null model & 88.63 & 365.65 & 454.28 & 19.51 \\
\hline + Citizen char. & 75.31 & 212.74 & 288.05 & 26.14 \\
\hline+ Frames of reference & 41.98 & 212.72 & 254.70 & 16.48 \\
\hline + Job char. & 34.39 & 212.74 & 247.13 & 13.92 \\
\hline+ Worker char. & 22.16 & 212.69 & 234.85 & 9.44 \\
\hline \multicolumn{5}{|l|}{ Application requirement } \\
\hline Null model & 1.11 & 3.29 & 4.40 & 25.15 \\
\hline + Citizen char. & 2.20 & 3.29 & 5.49 & 40.07 \\
\hline+ Frames of reference & 2.02 & 3.29 & 5.31 & 38.04 \\
\hline + Job characteristics & 1.09 & 3.29 & 4.38 & 24.89 \\
\hline + Worker char. & 0.53 & 3.29 & 3.77 & 12.73 \\
\hline \multicolumn{5}{|l|}{ Further diagnosis } \\
\hline Null model & 0.76 & 3.29 & 4.05 & 18.77 \\
\hline + Citizen char. & 2.22 & 3.29 & 5.51 & 40.29 \\
\hline+ Frames of reference & 2.01 & 3.29 & 5.30 & 37.93 \\
\hline + Job char. & 1.44 & 3.29 & 4.73 & 30.44 \\
\hline + Worker char. & 0.45 & 3.29 & 3.74 & 12.03 \\
\hline \multicolumn{5}{|l|}{ Job mediation } \\
\hline Null model & 1.04 & 3.29 & 4.33 & 24.02 \\
\hline + Citizen char. & 1.50 & 3.29 & 4.79 & 31.32 \\
\hline+ Frames of reference & 1.15 & 3.29 & 4.44 & 25.90 \\
\hline + Job char. & 1.10 & 3.29 & 4.39 & 25.06 \\
\hline + Worker char. & 0.18 & 3.29 & 3.47 & 5.19 \\
\hline \multicolumn{5}{|l|}{ Personal development } \\
\hline Null model & 2.95 & 3.29 & 6.24 & 47.28 \\
\hline + Citizen char. & 3.46 & 3.29 & 6.75 & 51.26 \\
\hline+ Frames of reference & 2.77 & 3.29 & 6.06 & 45.71 \\
\hline + Job char. & 1.85 & 3.29 & 5.14 & 35.99 \\
\hline+ Worker char. & 0.00 & 3.29 & 3.29 & 0.00 \\
\hline \multicolumn{5}{|l|}{ Activities } \\
\hline Null model & 1.88 & 3.29 & 5.17 & 36.36 \\
\hline + Citizen char. & 2.57 & 3.29 & 5.86 & 43.86 \\
\hline+ Frames of reference & 1.97 & 3.29 & 5.26 & 37.45 \\
\hline + Job char. & 1.48 & 3.29 & 4.77 & 31.03 \\
\hline + Worker char. & 0.68 & 3.29 & 3.97 & 17.13 \\
\hline
\end{tabular}

Source: Author's own calculations.

Notes: VPC denotes the variance partition coefficient, that is, the share of between caseworker variance in the total variance. Char. stands for characteristics. $N$ at level 1 (vignettes) $=630, N$ at level 2 (activation workers) $=53$. 
A consistent result for the use of enabling policy instruments was that the effects of the work-focused and the care-focused frame variables were not equal, and that the latter was always larger. Expressed differently, even when citizen characteristics, characteristics of the job design and team membership, as well as workers' personal and socio-economic background are controlled for, there are systematic and in practice non-negligible links between activation workers' ideas of what constitutes the essence of their work and the way in which they use enabling policy instruments.

Sixth, there are indeed systematic links between workplace characteristics and instruments. Table 5.8 shows that the inclusion of workplace characteristics decreased the unexplained variance further. For example, on average, the likelihood of demanding an application requirement was smaller for specialists. An integrated job design and a mixed target group were associated with larger odds of using this instrument. Seventh, as expected, individual worker characteristics played a role as well. For instance, caseworkers with personal experiences related to unemployment were more likely to use a job mediation instrument.

Against the results, the inherent limitations of factorial survey experiments can be discussed with reference to their construct, internal, and external validity (cf. Auspurg \& Hinz, 2015). Construct validity refers to the extent to which the survey question actually measures the idea that the researcher is interested in and whether or not the norms that are measured reflect respondents' real opinions. In this study, a way to measure frames of reference using a point-allocation method was proposed. The way in which the dimensions are correlated offers support for the validity of the construct. However, it would be desirable to continue testing validity, both in terms of comparisons across different respondent groups and across different measurements. Internal validity refers to the question of whether or not it is possible to make a claim of cause and effect. A causal relationship between two variables rests on three criteria, namely that the cause precedes the effect, that cause and effect covary, and that alternative explanations can be ruled out. In a factorial survey experiment, the set-up of the experiment is crucial. Internal validity was enhanced by following the methodological recommendations by Auspurg and Hinz (2015).

The most contentious aspect of a factorial survey experiment is its external validity and the question whether the same effects can be observed in different settings with other samples of activation workers or other measurements of the outcomes. One important point is that the sample is not representative of activation workers in the Netherlands and, due to non-response, most likely even not of activation workers 
in Maastricht. By design, there is only limited information that can be provided within a vignette and additional "real-world noise" is excluded in this very controlled setting. In reality, activation workers certainly probe into a range of other factors that could influence their decision-making. Furthermore, interactions between activation workers and citizens are also influenced by the atmosphere of the meeting, body language, or facial expressions. Nonetheless, it is this very controlled setting and the elimination of noise that is also one of the major strengths of the factorial survey. The best way forward to enhance external validity is to compare study results across a range of settings, respondent samples, and methods. For this specific topic, it could also be desirable to add organisations as an additional level (as done by De Wilde \& Marchal, 2018, in Belgium) and to investigate to what extent unexplained outcome variance is located at the organisational level.

\subsection{Conclusion}

The aim of this study was to investigate the extent to which activation workers share common warrants in their work, and to explore to what extent differences in judgements could be explained by characteristics of activation workers - the way in which their jobs are organised, their educational profiles, and their beliefs and role understanding. The importance of contextual factors, the considerable variations in contexts and, finally, in the treatment of citizens, has previously been emphasised by mostly qualitative research. A systematic analysis of these links, however, has so far only rarely been implemented. A way to do this by means of a newly designed factorial survey experiment was presented in this chapter.

The sampled group of activation workers was very diverse in terms of their education, their job design, their work preferences and role interpretation. In that sense, the sample appeared to be a good cross-section of caseworkers in the Netherlands. In particular, a look at educational profiles shows that what defines an activation worker is apparently not his/her education, but the task. Moreover, the survey results point to the diversity of job design even within one organisation as well as the complexity of tasks undertaken by them. Many activation workers have to carry out more than one major task and to cater for the needs of mixed target groups. Finally, workers differ in the relative importance that they attach to different work objectives. To some extent, there are indications of organisational subcultures within teams, yet the overall variation is still high. 
The experimental results indicate that these differences can indeed be linked to different frontline practices. This goes beyond tailor-making interventions based on citizen characteristics, even though caseworkers share some ideas. For instance, caseworkers are more likely to impose a job search requirement in circumstances where they assess labour market chances more positively. Job mediation and personal development instruments are more likely to be employed for persons that are presumably more likely to find a job in the short term, whereas further activities (such as social activation or sheltered employment) tend to be employed as it appears more and more unlikely that a recipient will find a job quickly. Yet, even when it is controlled for citizen characteristics, characteristics of the job design and team membership, as well as workers' personal, socio-economic background, their frames of reference exert a non-negligible influence on their decision-making. A telling example is that for a typical unemployed person, the likelihood of being assigned to job mediation can change by more than ten percentage points, merely depending on whether the caseworker tends more towards the idea that she should provide services that citizens need, or to understand her role more as having to promote outflow of citizens into work. Even before that, these different frames influence how caseworkers assess labour market chances. Caseworkers in the latter, work-focused frame thought that the same average citizen would be more likely to find a job within twelve months as compared to the care-focused colleague.

There are a number of policy implications of this study and questions that it raises. First, what does it actually mean to work as an activation worker? What are the expectations by the Participation Act (for instance, calling for uniform sanctioning practices), by municipalities (given their differing underlying principles), by the professional associations that are in the process of being established and, finally, individuals themselves? Framed differently, to what extent is it desirable that individual worker characteristics influence the treatment of citizens? In case that the answer is that this is not desirable, how can this be avoided? Second, the question of how caseworkers exploit their discretion links to a field experiment conducted by Bolhaar, Ketel, and van der Klaauw (2018) in Amsterdam. The authors found considerable heterogeneity in how caseworkers assigned citizens to different policy regimes. Interestingly, they also saw that empirical evidence on the impact of instruments did not motivate caseworkers to focus on effective interventions. These conclusions along with the results of this study mean that not only are beliefs important and influential on treatment decisions, but that it is also difficult to update these beliefs in light of new evidence. This warrants not only discussions at the national and municipal policy level and among professional organisations, but also 
questions of how frontline workers' beliefs can be changed.

Clearly, this study is only a first step and comparative analyses with different samples and methods are needed, specifically to further look at construct validity and external validity. Nonetheless, the factorial survey experiment revealed a number of patterns related to activation workers' beliefs that did not occur by chance. This raises questions on the extent to which it is desirable or at least acceptable that citizens' real opportunities can be influenced by caseworkers' beliefs that might not even be shared by colleagues or supported by organisational goals or legal frameworks. This emphasises the need to discuss and develop a shared professional identity of caseworkers, as well as the need for caseworkers to regularly reflect together on the principles that should guide their work. 


\section{References}

Altreiter, C., \& Leibetseder, B. (2015). Constructing inequality: Deserving and undeserving clients in Austrian social assistance offices. Journal of Social Policy, 44 (1), 127-145.

Auspurg, K., \& Hinz, T. (2015). Factorial survey experiments (No. 175). Thousand Oaks, CA: SAGE Publications.

Behncke, S., Frölich, M., \& Lechner, M. (2010). Unemployed and their caseworkers: Should they be friends or foes? Journal of the Royal Statistical Society: Series A (Statistics in Society), 173(1), 67-92.

Bolhaar, J., Ketel, N., \& van der Klaauw, B. (2018). Caseworker's discretion and the effectiveness of welfare-to-work programs. IZA Discussion Paper Series No. 11666 .

Brodkin, E. Z. (2013a). Street-level organizations and the welfare state. In E. Z. Brodkin \& G. Marston (Eds.), Work and the welfare state. Street-level organisations and workfare policies (pp. 17-34). Washington, DC: Georgetown University Press.

Brodkin, E. Z. (2013b). Work and the welfare state. In E. Z. Brodkin \& G. Marston (Eds.), Work and the welfare state. Street-level organisations and workfare policies (pp. 3-16). Washington, DC: Georgetown University Press.

Buss, C. (2018). Public opinion towards targeted labour market policies: A vignette study on the perceived deservingness of the unemployed. Journal of European Social Policy, 1-13.

Caswell, D., Kupka, P., Larsen, F., \& van Berkel, R. (2017). The frontline delivery of welfare-to-work in context. In R. van Berkel, D. Caswell, P. Kupka, \& F. Larsen (Eds.), Frontline delivery of welfare-to-work policies in Europe: Activating the unemployed (pp. 1-11). New York, NY: Routledge.

Caswell, D., Larsen, F., van Berkel, R., \& Kupka, P. (2017). Conclusions and topics for further research. In R. van Berkel, D. Caswell, P. Kupka, \& F. Larsen (Eds.), Frontline delivery of welfare-to-work policies in Europe: Activating the unemployed (pp. 181-200). New York, NY: Routledge.

De Wilde, M., \& Marchal, S. (2018). Weighing up work willingness in social assistance: A balancing act on multiple levels. University of Antwerp, Herman Deleeck Centre for Social Policy, Working Paper, No. 18.08.

Dingeldey, I. (2007). Between workfare and enablement - The different paths to transformation of the welfare state: A comparative analysis of activating 
labour market policies. European Journal of Political Research, 46(6), 823851.

Dülmer, H. (2007). Experimental plans in factorial surveys: Random or quota design? Sociological Methods \& Research, 35(3), 382-409.

Dülmer, H. (2016). The factorial survey: Design selection and its impact on reliability and internal validity. Sociological Methods \& Research, 45 (2), 304-347.

Dunn, A. (2013). Activation workers' perceptions of their long-term unemployed clients' attitudes towards employment. Journal of Social Policy, 42(4), 799817.

Eichhorst, W., Kaufmann, O., Konle-Seidl, R., \& Reinhard, H.-J. (2008). Bringing the jobless into work? An introduction to activation policies. In W. Eichhorst, O. Kaufmann, \& R. Konle-Seidl (Eds.), Bringing the jobless into work? Experiences with activation schemes in Europe and the US (pp. 1-16). Heidelberg, Germany: Springer.

Eikenaar, T., de Rijk, A. E., \& Meershoek, A. (2016). What's in a frame? How professionals assess clients in Dutch work reintegration practice. Social Policy \& Administration, 50(7), 767-786.

Fuertes, V., \& Lindsay, C. (2016). Personalization and street-level practice in activation: The case of the UK's work programme. Public Administration, $94(2), 526-541$.

Gauthier, D. P. (1963). Practical reasoning: The structure and foundations of prudential and moral arguments and their exemplification in discourse. Oxford, United Kingdom: Clarendon Press.

Government of the Netherlands. (2016). Verplichtingen cliënten (Participatiewet, informatie voor gemeenten). Retrieved June 25, 2016, from https://www.rijksoverheid.nl/documenten/publicaties/2016/02/ 23/verplichtingen-clienten

Hainmüller, J., Hangartner, D., \& Yamamoto, T. (2015). Validating vignette and conjoint survey experiments against real-world behavior. Proceedings of the National Academy of Sciences, 112(8), 2395-2400.

Hasenfeld, Y. (2010). Organizational responses to social policy: The case of welfare reform. Administration in Social Work, 34(2), 148-167.

Hupe, P., \& Hill, M. (2007). Street-level bureaucracy and public accountability. Public Administration, 85(2), 279-299.

Inspectie SZW. (2017). Handhaving arbeidsverplichtingen. Inspectie SZW, Ministerie van Sociale Zaken en Werkgelegenheid.

Jann, B. (2014). Plotting regression coefficients and other estimates. The Stata 
Journal, $14(4), 708-737$.

Jessen, J. T., \& Tufte, P. A. (2014). Discretionary decision-making in a changing context of activation policies and welfare reforms. Journal of Social Policy, 43(2), 269-288.

Jilke, S., \& Tummers, L. (2018). Which clients are deserving of help? A theoretical model and experimental test. Journal of Public Administration Research and Theory, 28(2), 226-253.

Kremer, M., van de Meer, J., \& Ham, M. (2017). Werkt de zachte hand in de bijstand? Tijdschrift voor Sociale Vraagstukken, Winter 2017(4), 14-19.

Lipsky, M. (1980). Street-level bureaucracy: The dilemmas of the individual in public service. New York, NY: Russell Sage Foundation.

Lødemel, I., \& Moreira, A. (2014). Introduction. In I. Lødemel \& A. Moreira (Eds.), Activation or workfare? Governance and the neo-liberal convergence (p. 1-18). Oxford, United Kingdom: Oxford University Press.

Marchal, S., \& Mechelen, N. (2017). A new kid in town? Active inclusion elements in European minimum income schemes. Social Policy \& Administration, 51(1), 171-194.

Maynard-Moody, S., \& Musheno, M. (2000). State agent or citizen agent: Two narratives of discretion. Journal of Public Administration Research and Theory, $10(2), 329-358$.

Nothdurfter, U. (2016). The street-level delivery of activation policies: Constraints and possibilities for a practice of citizenship. European Journal of Social Work, $19(3-4), 420-440$.

Rice, D. (2013). Street-level bureaucrats and the welfare state: Toward a microinstitutionalist theory of policy implementation. Administration $\&$ Society, 45(9), 1038-1062.

Rosenthal, P., \& Peccei, R. (2006). The social construction of clients by service agents in reformed welfare administration. Human Relations, 59(12), 16331658 .

Rossi, P. H., \& Anderson, A. B. (1982). The factorial survey approach. An introduction. In P. H. Rossi \& S. L. Nock (Eds.), Measuring social judgments: The factorial survey approach (pp. 15-67). Beverly Hills, CA: Sage Publications.

Sauer, C., Auspurg, K., Hinz, T., \& Liebig, S. (2011). The application of factorial surveys in general population samples: The effects of respondent age and education on response times and response consistency. Survey Research Methods, $5(3), 89-102$.

Solvang, I. (2017). Discretionary approaches to social workers' personalisation of 
activation services for long-term welfare recipients. European Journal of Social Work, $20(4), 536-547$.

Terum, L. I., Torsvik, G., \& Øverbye, E. (2018). Discrimination against ethnic minorities in activation programme? Evidence from a vignette experiment. Journal of Social Policy, 47(1), 39-56.

Toulmin, S. (1958). The uses of argument. Cambridge, United Kingdom: Cambridge University Press.

van Berkel, R. (2017a). State of the art in frontlines studies of welfare-to-work. In R. van Berkel, D. Caswell, P. Kupka, \& F. Larsen (Eds.), Frontline delivery of welfare-to-work policies in Europe: Activating the unemployed (p. 12-35). New York, NY: Routledge.

van Berkel, R. (2017b). The street-level activation of the unemployed remote and very remote from the labour market. The Dutch case. In R. van Berkel, D. Caswell, P. Kupka, \& F. Larsen (Eds.), Frontline delivery of welfare-towork policies in Europe: Activating the unemployed (pp. 144-162). New York, NY: Routledge.

van Berkel, R., \& Knies, E. (2018). The frontline delivery of activation: Workers' preferences and their antecedents. European Journal of Social Work, 21(4), 602-615.

van Berkel, R., \& van der Aa, P. (2012). Activation work: Policy programme administration or professional service provision? Journal of Social Policy, $41(3), 493-510$.

van Berkel, R., van der Aa, P., \& Van Gestel, N. (2010). Professionals without a profession? Redesigning case management in Dutch local welfare agencies. European Journal of Social Work, 13(4), 447-463.

van Oorschot, W., Roosma, F., Meuleman, B., \& Reeskens, T. (2017). The social legitimacy of targeted welfare: Attitudes to welfare deservingness. Cheltenham, United Kingdom: Edward Elgar Publishing.

Wallander, L. (2009). 25 years of factorial surveys in sociology: A review. Social Science Research, 38(3), 505-520.

Wallander, L., \& Molander, A. (2014). Disentangling professional discretion: A conceptual and methodological approach. Professions and Professionalism, $4(3), 1-19$.

Wanberg, C. R., Hough, L. M., \& Song, Z. (2002). Predictive validity of a multidisciplinary model of reemployment success. Journal of Applied Psychology, $87(6), 1100-1120$.

Wheeler, R. E. (2004a). optBlock. AlgDesign. The R project for statistical computing. 
Retrieved May 25, 2018, from http://www.r-project.org/

Wheeler, R. E. (2004b). optFederov. AlgDesign. The $R$ project for statistical computing. Retrieved May 28, 2018, from http://www.r-project.org/ 


\section{Conclusion}

This thesis set out to systematically rethink activation policy by moving away from a narrow focus on individual responsibility, and by re-embedding economic actions into a social context. The need for the research was motivated by the observation that a defining feature of welfare reforms in many developed countries has been an emphasis on active welfare arrangements, framed within a discourse which focuses on the increased responsibility of the individual vis-à-vis the state. The conceptualisation of the "active welfare subject" (Wright, 2016, p. 235) has been fiercely debated both among academics and in policy circles for decades. Questions on how to characterise the welfare subject are important in and of themselves, raising issues such as the risk of reinforcing prejudices and undermining social solidarity. These questions are just as crucial, however, when these assumptions about human behaviour and decision-making inform policymaking.

The case studied throughout this thesis was the implementation of the Participation Act in the Netherlands, which entered into force in 2015. The Participation Act is an interesting and relevant case to study in several respects. The discussions leading to the introduction of the law had rarely been backed up by explicit, evidence-based accounts on why this should be the preferred way to bring more people into work. Equally, the potential effects of such a policy on individuals' lives was rarely addressed beyond the economic domain, with little to no attention paid to the specific effects of different policy instruments, or potentially varying effects of such instruments depending on citizen characteristics. Furthermore, and somewhat surprisingly, the perspectives of social assistance recipients themselves were hardly heard. All these aspects have been taken up only more recently, mostly by policy actors at the municipal level, often joining forces with academia. This movement from the grassroots has started to voice its critical view on different aspects of the Participation Act and the currently prevalent approach of inducing certain behaviours and punishing others - a model of increased individual responsibility, but on terms prescribed by the state (Peeters \& Drosterij, 2011; van Echelt \& Josten, 2012).

Against this background, the aim of this dissertation was to look at the design of the Dutch social assistance scheme and activation policy, mainly from the point 
of view of the lived experiences of recipients and with particular attention to their relative position in society. In a series of subsequent studies, the decision context of social assistance recipients and the effect of different activation policy instruments on their well-being and agency was examined, which directly informed the design of a policy instrument. Reflections on the contribution of this thesis to academic literature, on the overall results, and on policy implications are summarised through the following four points: (i) the value of multidisciplinary and mixed-methods research to explicitly link assumptions and policy design; (ii) the deeper understanding of the effects of a policy by broadening the set of outcome measures; (iii) the use of a two-dimensional activation typology to study the effects of different instruments; and (iv) the more nuanced understanding of the effects of a policy by adding the role of the activation worker explicitly to the equation.

From a methodological view point, this thesis showcased how multidisciplinary and mixed-methods research can be used to make an explicit link between assumptions, policy design, and policy outcomes. Specifically, this thesis demonstrated that a sequential exploratory research design (cf. Creswell, 2009) contributed to uncovering gaps in separate strands of literature, and could be used to draw links between and combine these literatures in mutually beneficial ways. Literature on the psychosocial effects of living in poverty or with benefits, for instance, provides great depth of insight into individuals' well-being, including relational aspects. But it has so far rarely aimed to unveil the links between well-being and agency and different types or mixes of activation instruments that create incentives or provide active support. Yet this is important, particularly when the aim is to inform policy design by evaluating the effects of activation policy in a more in-depth way. For that purpose, this thesis built on literature on activation typologies, which is more often used to study questions of policy convergence or divergence. Impact evaluations, in turn, frequently focus narrowly on employment-related outcomes, thereby neglecting the well-being of citizens while they are receiving benefits, as well as the way in which citizens are embedded in social structures and the role of activation workers.

The exploratory phase therefore enlarged the evaluative space that is commonly used to assess activation policy by means of analysing authentic accounts of 45 social assistance recipients' experiences in the Dutch welfare state through the lens of the capability approach. By building on a two-dimensional, instrument-oriented activation typology, the first two empirical chapters demonstrated the conditions under which activation instruments can enhance or limit citizens' well-being and agency. The qualitative research phase showed that it is basically impossible to 
conceive activation policy on a merely individual level, but that its effects need to be seen in relation to the labour market, as well as the mediating role of activation workers, significant others and society at large. In addition, Chapters 2 and 3 illustrated the significant discordance between a top-down conception of the welfare recipient that is implied in the design and delivery of a number of coercive elements of Dutch activation policy (and is explicit in the writings of Charles Murray (1984) or Lawrence Mead (1986)) and a bottom-up view based on the lived experiences of social assistance recipients (also found, for example, in articles of Ruth Lister (2004; 2015), Ruth Patrick (2014; 2017a; 2017b), or Sharon Wright (2012; 2016), or in work in the Netherlands by Kampen and Tonkens (2019)). The chapters showed how these clashes could introduce an additional toll on social assistance recipients, who are left with the feeling that they do not only have to engage in strategies to manage their daily lives and to create future perspectives, but also to defend their lives, and even their feelings of personal integrity, against a rhetoric of alleged irresponsibility and inactivity. The chapters also demonstrated how coercive elements meant to 'activate' citizens might do exactly the opposite by taking away feelings of personal control; and how a group of individuals can be put at risk of deeper exclusion - a risk that is present from the outset for social assistance beneficiaries - as non-participation could too easily be equated with non-willingness to contribute to society.

Particularly in the current favourable economic environment, one concern is that a rhetoric that emphasises personal responsibility, along with a policy design that safeguards against (and thereby implicitly assumes) lack of motivation and irresponsible choices, can lead to an even more vicious rhetoric on lifestyle choices and a sharpening of relational and societal fault lines. This is an important consequence for policymakers to notice as they might even not be aware of the implications that their assumptions carry for beneficiaries. Taking this idea further, policymakers could ask themselves to what extent there are different perceptions of and benchmarks for poor and rich people, unemployed and employed individuals, and what the causes and consequences of these perceptions are. Some years ago, the Netherlands Institute for Social Research studied the role of increased personal responsibility in Dutch policymaking. One part of the study investigated individuals' responsibility to earn their own living (van Echelt \& Josten, 2012). In addition to policies related to the reintegration of unemployed people, it looked at policies to maintain employed peoples' employability and thereby offered a comparative perspective. Van Echelt and Josten (2012) concluded that policies directed to people who were out of employment were much more prescriptive, which is certainly associated with the stronger link between rights and obligations. Nonetheless, they also noticed a dif- 
ferent guiding conception of the human being, with more mistrust being expressed towards unemployed persons - not only in the law, but also in representative opinion polls. Respondents were, for instance, in favour of stricter application requirements for persons out of work. This leads us back to the starting point of this thesis, namely the pervasiveness of assumptions. There is the risk that the more distrust towards social assistance recipients is written into a law, the more this view becomes engrained in society, and vice versa. There needs to be a broader understanding that the decision-making of people living in poverty is in part a consequence of our societal architecture, namely the way in which society is built up (cf. Sheehy-Skeffington, 2015). If this is not acknowledged, it is likely that solutions to structural inequalities will continue to be sought only at the individual level (cf. Edmiston, 2018).

The findings in the first two empirical chapters corroborated findings from the Welfare Conditionality project in the UK, as well as from academic research carried out by scholars such as Sharon Wright and Ruth Patrick (2019) within and beyond this project. What made the research in this thesis interesting from a theoretical point of view, however, was that it took advantage of the Dutch activation policy mix and additionally studied the effects of instruments not only in the dimension of incentive construction, but also the dimension of active support. Chapters 2 and 3 provided examples of activities such as participation placements or volunteer work that had the potential to have a positive effect on individuals' well-being and agency by giving them the opportunity to make active choices and to shape their environments in meaningful ways. Consequently, in addition to contributing to the understanding of the 'vicious cycles' between loss of control and coercion, these chapters added to the academic literature by describing how 'virtuous cycles' could be created if active support and case management were in line with citizens' own preferences and/or the perceived labour market situation. Particularly in light of the fact that local welfare agencies have more recently expressed very different takes on their understanding of human motivation, decision-making or choice, or trust and personal autonomy (Kremer, van de Meer, \& Ham, 2017), and hence their preferred activation policy mix in the dimension of active support, future research can take advantage of these differences and investigate these questions in a comparative way across municipalities.

Chapter 2 and Chapter 3 had shown the value of studying the decision context of social assistance recipients and of broadening the outcome measures that literature on activation policy commonly looks at in order to grasp the "potential longer term, more insidious, 'side-effects"' (Brown, 2012, p. 306) of the current Dutch activation 
policy and the participation paradox (Hindriks, 2015) that is inherent in its design. This broader evaluative space offers more opportunities to inform policy design. In this case, the key themes and patterns that were identified led to a consideration of self-affirmation theory, a social psychology theory, in order to develop and test an instrument that could contribute to increased well-being and agency. The conceptual framework let us to expect that this self-affirmative exercise could have positive effects on citizens' well-being (higher sense of self-worth, reduced stress levels, stronger feelings of societal belonging) and agency (heightened job search-related self-efficacy and cognitive performance). However, the results of a randomised controlled trial with 174 social assistance applicants showed that self-affirmation did not benefit every applicant. It was indeed a catalyst for improved job search behaviour self-efficacy for citizens who might face more reintegration challenges. Contrary to our expectations, however, the self-affirmation reinforced negative feelings among a group of people that have better labour market perspectives.

The results presented in Chapter 4, in conjunction with the results of Chapters 2 and 3, identify a drawback of self-affirmation. It responds to a symptom rather than the cause of feelings of stigma and stereotype threat, and does not address power relations. This leads to further research avenues. First, to what extent can a self-affirmative exercise in this context propagate in the future by initiating positive feedback loops between the self system and the social system (cf. Cohen \& Sherman, 2014)? And could this missing piece be brought in by linking these results to academic literature on social class, power, and status, as for instance carried out by Sheehy-Skeffington (2018) or Kraus, Park, and Tan (2017)? Furthermore, and particularly from the perspective of policymakers, Chapter 4 showed that it is crucial that researchers test psychological theories in the field in order to generate policy-relevant insights, as these theories are to a large extent developed in the lab with non-standard populations (cf. Hall, Galvez, \& Sederbaum, 2014; Harrison \& List, 2004).

Finally, linking the four chapters, we see the implications of activation workers' frames of reference and role understanding on their actions, and the impact of their actions for the well-being and agency of citizens. Throughout the thesis, it became clear that what currently unites activation workers is the fact that they do the same task, and not that they necessarily share the same background and values. Activation workers have varying ideas of what their work entails. Not surprisingly, these ideas differ across individuals, as well as across groups of individuals, for instance along the lines of team membership. The important point that Chapter 5 
illustrated is that these frames matter for the treatment of citizens, even when citizen characteristics, activation workers' educational and socioeconomic backgrounds, and team membership are controlled for. Previous literature has often referred to the black box of decision-making and the factorial survey experiment with 53 activation workers in this thesis contributed to opening it up. These results can also be linked back to the discussions on the active welfare subject referred to above, as it shows another arena in which conceptions of the citizen are highly contested.

In light of the fact that the results presented in the previous chapters had shown that activation workers can influence the agency and well-being of citizens far beyond the written law, Chapter 5 warns us that even adjustments in laws or regulations might not be enough to change mindsets of activation workers in the short run (see also Bolhaar, Ketel, \& van der Klaauw, 2018). There is both a necessity and a chance to discuss what values are/should be at the core of activation work, and to use these discussions to develop the professional identity of activation workers. Beyond these policy implications, the chapters showed that Lipsky's seminal research is still timely, and that academic literature on the links between welfare reform and the practice and experience of social citizenship (e.g. Edmiston, Patrick, \& Garthwaite, 2017) needs to factor in the role of frontline workers, as "they hold the keys to a dimension of citizenship" (Lipsky, 1980, p. 4).

In conclusion, the terms activation and responsibility and their uses need to be critically rethought. It is important to recognise that these terms are not neutral. The concept of activation is loaded with assumptions about behaviour and rethinking it needs to start from a recognition of these assumptions and the connotations of the term. Equally, the use of the term responsibility should be reconsidered. What does it actually mean in these debates? Is the discussion about the economic or the social actor? Even if the activation and responsibility rhetoric is referring to the economic actor only, this research has shown that this rhetoric can have repercussions for the societal actor as well. This is illustrated in the creation or reinforcement of existing division in society, casting shame on individuals or attacking people's feelings of self-worth and personal integrity - all outcomes that would commonly not show up in the assessment of activation policy, yet are crucial for a society that claims to be participatory. The idea that everybody in society has equal chances and that it is effort alone that determines to what extent somebody can participate is deceptive. This comprises a rather individualistic outlook that neglects the fact that the equation "merit = intelligence + effort" contains more random and structural effects than is often acknowledged. Based on a comparison of social class divisions 
and the divisions created by the idea of meritocracy, Adamson (2018) stated that "we should revive the idea that all people are of equal value and that a fair society is one that opens up the possibility of life-satisfaction, in all of its varieties, to all of its members" (para. 58). In the context of this research, I would rephrase the statement by saying that a fair society is a society that opens up the substantive freedom to all its members to live a life in which they can conceive themselves as worthy human beings - worth not measured in terms of economic output alone, but taking into account the full range of activities that contribute to an individual's well-being, as well as those activities such as giving birth, caring for children or the elderly, volunteering, or continued training and education, that together contribute and give meaning to the communities and societies of which we are all part. 


\section{References}

Adamson, P. (2018, September 27). Long read: The merit trap. Retrieved December 18, 2018, from https://newint.org/features/long-read/2018/09/27/ long-read-merit-trap-ability-and-heritability

Bolhaar, J., Ketel, N., \& van der Klaauw, B. (2018). Caseworker's discretion and the effectiveness of welfare-to-work programs. IZA Discussion Paper Series No. 11666 .

Brown, P. (2012). A nudge in the right direction? Towards a sociological engagement with libertarian paternalism. Social Policy and Society, 11(3), 305-317.

Cohen, G. L., \& Sherman, D. K. (2014). The psychology of change: Self-affirmation and social psychological intervention. Annual Review of Psychology, 65, 333371.

Creswell, J. W. (2009). Research design: Qualitative, quantitative, and mixed methods approaches (Third ed.). London, United Kingdom: SAGE Publications.

Edmiston, D. (2018). The poor "sociological imagination" of the rich: Explaining attitudinal divergence towards welfare, inequality, and redistribution. Social Policy E Administration, 52(5), 983-997.

Edmiston, D., Patrick, R., \& Garthwaite, K. (2017). Introduction: Austerity, welfare and social citizenship. Social Policy and Society, 16(2), 253-259.

Hall, C. C., Galvez, M. M., \& Sederbaum, I. M. (2014). Assumptions about behavior and choice in response to public assistance: A behavioral decision analysis. Policy Insights from the Behavioral and Brain Sciences, 1(1), 137-143.

Harrison, G. W., \& List, J. A. (2004). Field experiments. Journal of Economic Literature, 42(4), 1009-1055.

Hindriks, F. (2015, October). Gedeelde verantwoordelijkheid in een verdeelde samenleving. Oratie uitgesproken door Prof. dr. F.A. Hindriks bij de aanvaarding van het ambt van hogleraar in de Ethiek, Sociale en Politieke Filosofie.

Kampen, T., \& Tonkens, E. (2019). Empowerment and disempowerment of workfare volunteers: A diachronic approach to activation policy in the Netherlands. Social Policy and Society, 18(3), 351-364.

Kraus, M. W., Park, J. W., \& Tan, J. J. X. (2017). Signs of social class: The experience of economic inequality in everyday life. Perspectives on Psychological Science, 12(3), 422-435.

Kremer, M., van de Meer, J., \& Ham, M. (2017). Werkt de zachte hand in de bijstand? Tijdschrift voor Sociale Vraagstukken, Winter 2017(4), 14-19. 
Lipsky, M. (1980). Street-level bureaucracy: The dilemmas of the individual in public service. New York, NY: Russell Sage Foundation.

Lister, R. (2004). Poverty. Cambridge, United Kingdom: Polity.

Lister, R. (2015). 'To count for nothing': Poverty beyond the statistics. Journal of the British Academy, 3, 139-165.

Mead, L. M. (1986). Beyond entitlement. The social obligations of citizenship. New York, NY: The Free Press.

Murray, C. A. (1984). Losing ground: American social policy, 1950-1980. New York, NY: BasicBooks.

Patrick, R. (2014). Working on welfare: Findings from a qualitative longitudinal study into the lived experiences of welfare reform in the UK. Journal of Social Policy, 43(4), 705-725.

Patrick, R. (2017a). For whose benefit? The everyday realities of welfare reform. Bristol, United Kingdom: Policy Press.

Patrick, R. (2017b). Wither social citizenship? Lived experiences of citizenship in/exclusion for recipients of out-of-work benefits. Social Policy and Society, $16(2), 293-304$.

Peeters, R., \& Drosterij, G. (2011). Verantwoordelijke vrijheid: Responsabilisering van burgers op voorwaarden van de staat. Beleid en Maatschappij, 38(2), 179-189.

Sheehy-Skeffington, J. (2015). Behavioural insights in the age of austerity: How the new 'psychology of poverty' can help us to stay focused on society. Angle Journal, 13. Retrieved October 21, 2016, from https://anglejournal.com/article/2015-12-behavioural-insights-in -the-age-of-austerity-how-research-on-the-psychology-of-poverty -can-help-us-to-stay-focused-on-so/

Sheehy-Skeffington, J. (2018). Decision-making up against the wall: A framework for understanding the behavioural dimension of low socioeconomic status. In A. K. Üskül \& S. Oishi (Eds.), Socio-economic environment and human psychology: Social, ecological, and culturalperspectives (p. 1-33). Oxford, United Kingdom: Oxford University Press.

van Echelt, P., \& Josten, E. (2012). Werken voor je geld. In V. Veldheer, J.J. Jonker, L. Van Noije, \& C. Vrooman (Eds.), Een beroep op de burger. Minder verzorgingsstaat, meer eigen verantwoordelijkheid? (pp. 95-115). The Hague, the Netherlands: Sociaal en Cultureel Planbureau.

Wright, S. (2012). Welfare-to-work, agency and personal responsibility. Journal of Social Policy, 41(2), 309-328. 
Wright, S. (2016). Conceptualising the active welfare subject: Welfare reform in discourse, policy and lived experience. Policy 65 Politics, 44 (2), 235-252.

Wright, S., \& Patrick, R. (2019). Welfare conditionality in lived experience: Aggregating qualitative longitudinal research. Social Policy and Society, 18(4), $597-613$. 
Appendices 



\section{Appendix A: Interview Guide}

$M B$ : We willen u graag bedanken dat $\mathrm{u}$ wilt deelnemen aan het interview. Mijn naam is Mira Bierbaum. Ik ben van de Universiteit Maastricht en ik ben verantwoordelijk voor dit onderzoek. Zoals $\mathrm{u}$ hoort kom ik niet uit Nederland, daarom ondersteunt Jáchyne Dejong mij en houdt het interview.

$J D$ : Mijn naam is Jáchyne Dejong. Ik kom uit Maastricht en ik werk samen met Mira aan dit onderzoek. Tijdens het interview zouden we graag iets meer te komen weten over uw ervaringen met uw leven met een uitkering, uw activiteiten om werk te vinden, wat voor ondersteunende factoren en moeilijkheden er voor u zijn, en wat $u$ over de activiteiten van de Sociale Dienst denkt. Er zijn geen goede of foute antwoorden, maar we zijn geïnteresseerd in wat u denkt en heeft ervaren.

We schatten dat het interview ongeveer een uur duurt, soms iets langer, soms iets korter. Alles wat $\mathrm{u}$ hier zegt wordt vertrouwelijk behandelt en uw naam zal in geen geval bekend worden gemaakt. Met name de Sociale Dienst en al haar medewerkers hebben geen toegang tot deze informatie. We praten met ongeveer 50 tot 60 mensen en maken een verslag. U naam zal niet worden vermeldt in dit verslag. Als $u$ geïnteresseerd bent in de uitkomsten van de interviews dan kunt $u$ een kopie van het verslag ontvangen.

Het interview is natuurlijk vrijwillig en $\mathrm{u}$ kunt het interview altijd stoppen als $\mathrm{u}$ het wilt. Als dank aan alle deelnemers verloten we aan het eind van dit onderzoek zes VVV-bonnen ten waarde van $€ 50$.

Tenslotte zouden we nog graag willen vragen of we het interview mogen opnemen. We zouden dan het gesprek nog eens kunnen terugluisteren. Het zou voor ons makkelijker zijn om het gesprek te kunnen volgen en we zouden graag zeker willen zijn dat we u goed begrijpen. Heeft u nog vragen? - Als u geen vragen meer heeft, mag ik u vragen a.u.b. de toestemmingsverklaring te tekenen?

Start tape recorder. Zeg datum, tijd en locatie, naam van de interviewer en wetenschapper, deelnemer ID (niet naam). 
I) Ervaring met het leven op uitkeringsbasis

1. Hoe ziet een doordeweekse dag voor $u$ eruit? Kunt $u$ ons er iets over vertellen?

2. En het weekend?

3. Zoals $\mathrm{u}$ weet, zijn we geïnteresseerd in uw ervaringen als bijstandsontvanger. Kunt $\mathrm{u}$ ons vertellen waarom $\mathrm{u}$ uitkering heeft aangevraagd?

- Sinds wanneer leeft u van de uitkering?

- Heeft u eerder uitkering aangevraagd?

- Wat had u gedaan voordat u uitkering kreeg?

4. Hoe voelt $\mathrm{u}$ zich in uw huidige situatie?

- Op een schaal van 0 tot 10 , hoe tevreden bent u met uw situatie? Kunt u ons voorbeelden geven? Heeft u zich altijd zo gevoeld?

- Hoe tevreden bent u met uw financiële situatie? Op een schaal van 0 tot 10? Kunt u ons voorbeelden geven? Heeft u zich altijd zo gevoeld?

- Hoe tevreden bent u met uw sociale leven? Op en schaal van 0 tot 10? Kunt u ons voorbeelden geven? Heeft u zich altijd zo gevoeld?

5. Is uw leven nu anders dan het was voordat u een uitkering ontving? Kunt $u$ ons voorbeelden geven? Heeft $u$ zich altijd zo gevoeld?

- Zijn er dingen die u nu kunt doen?

- Zijn er ook dingen die u misschien niet meer kunt doen?

6. Hoe reageren anderen op uw situatie? Is dit veranderd in de loop van de tijd? Hoe voelt $u$ zich erbij?

- Wat is de reactie van uw partner?

- En van uw familie?

- Van uw vrienden?

- En van uw buren? 
7. Op welke manier voelt $\mathrm{u}$ zich op dit moment onderdeel van de maatschappij? Is dit veranderd? Hoe voelt u zich erbij?

Alternatief indien de vorige vraag te abstract is:

- Wat denkt u, hoe bekijkt de maatschappij (of: andere mensen) personen die van een uitkering leven?

- Voelt u zich sociaal buitengesloten?

8. Hoe is uw netwerk veranderd sinds het ontvangen van uw uitkering, als het al veranderd is? Kunt u voorbeelden geven?

- Hoe ziet uw sociale netwerk er nu uit?

- In welke mate bent $u$ in contact met andere uitkeringsontvangers?

II) De betekenis van werk

9. $\mathrm{U}$ vertelde ons over uw huidige situatie. In welk opzicht denkt $\mathrm{u}$ dat het hebben van een baan een verschil zou maken in deze situatie? Kunt u ons voorbeelden geven? Waarom is dat belangrijk voor u?

10. Welke dingen wilt $\mathrm{u}$ uit uw werk halen? (Of simpelweg: Waarom wilt $\mathrm{u}$ graag werk hebben?) Waarom is dit belangrijk voor $u$ ? Heeft u zich altijd zo gevoeld? Of is dit veranderd?

Als iemand aangeeft dat werk niet belangrijk is of geen verschil maakt, dan kun je de volgende vragen stellen:

- Waarom denkt u dat werk voor andere mensen belangrijk is?

- Wat zou uw reactie kunnen veranderen?

III) Huidige werkzoekende activiteiten

11. Wat voor soort werk zoekt $\mathrm{u}$ ? Kunt u voorbeelden geven? Is dit veranderd in de loop van de tijd? Wat is de reden voor deze verandering? Welk ander werk kunt $u$ zich voorstellen dat $u$ zou doen?

Als iemand aangeeft dat hij of zij niet naar werk zoekt: Waarom zoekt u niet naar werk? Is dit veranderd in de loop der tijd? 
12. Kunt $\mathrm{u}$ vertellen wat $\mathrm{u}$ doet om werk te vinden? Kunt $\mathrm{u}$ een voorbeeld geven van de afgelopen week?

- Via welke kanalen/wegen zoekt u naar werk (krant, internet, netwerk via familie, vrienden, eerdere collega's)?

- Hoeveel tijd heeft u aan het vinden van werk besteed in de afgelopen week?

- Hoeveel sollicitaties heeft u geschreven in de afgelopen week?

- Hoe vaak bent u in contact geweest met werkgevers in de afgelopen week?

- Wanneer iemand een sollicitatie heeft gehad: Hoe is dit gegaan?

13. Is uw aanpak veranderd in de loop der tijd? Wat is de reden voor deze verandering?

14. Wat zou u anders kunnen doen om werk te vinden?

15. Stelt $u$ zich voor dat iemand $u$ een baan aanbiedt. Wat voor redenen zou u kunnen bedenken om de baan niet aan te nemen? Waarom is dat belangrijk? Heeft $u$ zich altijd zo gevoeld?

16. Hoe schat u uw huidige kansen in op het vinden van werk? Is dit veranderd in de loop der tijd?

17. Denkt $\mathrm{u}$ dat $\mathrm{u}$ dat kan beïnvloeden? Wat is de reden voor uw antwoord? Heeft u zich altijd zo gevoeld? Wat heeft hiertoe geleid?

IV) Obstakles en steunende factoren

18. Welke factoren maken het voor $\mathrm{u}$ moeilijk om werk te vinden en wat denkt $\mathrm{u}$ dat op dit moment $\mathrm{u}$ steun biedt bij het vinden van werk? Kunt $u$ ons hier meer over vertellen? Zijn er dingen veranderd? Wat heeft hiertoe geleid? Indien van toepassing: Heeft u ervaringen gehad waarbij het gelukt is?

Als iemand moeite heeft met het beantwoorden van deze vraag of de vraag is te breed, dan kan men vragen naar de laatste keer dat de geïnterviewde een poging deed om werk te vinden en dit te beschrijven. Wat is er 
gebeurd? Het is ook mogelijk om terug te gaan naar huidige werkzoekende activiteiten. Dit beschrijft $u$...

- Individuele factoren (voor alle vragen: Waarom doet dat ertoe?):

- In welke mate denkt u dat u de nodige vaardigheden heeft om werk te vinden? (Zoals: vacatures opzoeken, $C V$ en sollicitatiebrieven schrijven, interviews...)

- Hoe blijft u gemotiveerd bij het vinden van werk? Heeft u een bepaald plan (ontwikkeld)? (Bijvoorbeeld deadlines zetten, prioriteiten vaststellen, stappenplan ontwikkelen...)

- Zijn er andere factoren (fysische of psychische belemmeringen, huisvesting, verslaving, schulden, taalvaardigheden)?

- Externe factoren (voor alle vragen: Waarom doet dat ertoe?):

- Wat vindt u van de huidige arbeidsmarktsituatie?

- Maken kinderen het moeilijker om werk te vinden en te hebben? In welk opzicht? Zijn daar mensen binnen uw familie of kenniskring voor wie u moet zorgen? Om hoeveel uur gaat het dan?

- Welke rol spelen uw familie, vrienden, buren?

19. Denkt $\mathrm{u}$ dat er iets is wat $\mathrm{u}$ kan doen om met de obstakels om te gaan? Kunt $u$ een voorbeeld geven? Denkt $u$ dat dit veranderd is sinds het ontvangen van uitkering? Zo ja, wanneer?

20. Welke andere dingen, denkt $\mathrm{u}$, kunnen $\mathrm{u}$ steun bieden? Waarom is dat belangrijk voor u? Hoe zou dat uitzien?

V) Ervaringen met re-integratie activiteiten van de Sociale Dienst

21. Wat vindt $\mathrm{u}$ van de re-integratie activiteiten van de Sociale Dienst? Kunt $u$ hier voorbeelden van geven? Wat bieden ze? Waarom is dat belangrijk voor u? Is dit veranderd?

22. Indien van toepassing: Hiervoor zei $\mathrm{u}$ een aantal dingen die het voor $\mathrm{u}$ moeilijk maken om een baan te vinden. Hoe denkt $u$ dat de activiteiten van de Sociale Dienst van toepassing zijn? 
23. Kunt $\mathrm{u}$ ons iets vertellen over uw verplichtingen als uitkeringsontvanger? Hoe gaat u ermee om? Waarom is dat belangrijk voor $u$ ? Hoe voelt u zich hierbij?

24. Wat denkt $\mathrm{u}$ over het opleggen van maatregelen, wanneer $\mathrm{u}$ zich niet aan de regels houdt? Maakt dat iets voor u uit?

25. Hoe denkt u over uw relatie met uw consulent? Is deze relatie belangrijk voor $u$ ? Hoe voelt $u$ zich hierbij?

26. Stelt $\mathrm{u}$ zich voor dat $\mathrm{u}$ iets kan veranderen aan de re-integratie activiteiten van de Sociale Dienst. Wat zou u veranderen? Wat is hieraan belangrijk voor $u$ ?

VI) Doelen voor de toekomst

27. Wat zijn uw dromen voor de toekomst?

28. Waar ziet u zichzelf over vijf jaar?

29. Indien geïnterviewde kinderen heeft: Wat zijn uw dromen voor uw kinderen?

30. Wat kan u tegenhouden?

31. Wat helpt u om uw dromen te verwezenlijken?

$\underline{\text { Persoonlijke achtergrond }}$

Voordat we stoppen, willen we graag wat laatste informatie over uw persoonlijke achtergrond (interviewer vult de gegevens in).

Einde interview

Wij hebben verder geen vragen meer. Is er iets dat $u$ nog graag wilt vertellen, voordat we het interview beëindigen?

- Bedankt voor uw deelname.

- Feedback formulier. 


\section{Persoonlijke achtergrond}

1. Geslacht $\square$ Man $\square$ Vrouw

2. Leeftijd

3. Postcode

(4 cijfers, 2 let-

ters)

4. Nationaliteit

5. Herkomst $\square$ Autochtoon

$\square$ Allochtoon (Land:

$\square$ Eerstegeneratieallochtoon (in Nederland sinds $\longrightarrow$ )

$\square$ Tweedegeneratieallochtoon

Definities voor interviewer (Centraal Bureau voor de Statistiek, 2015):

Autochtoon: Persoon van wie de beide ouders in Nederland zijn geboren, ongeacht het land waar men zelf is geboren.

Allochtoon: Persoon van wie ten minste één ouder in het buitenland is geboren.

Eerstegeneratieallochtoon: Persoon die in het buitenland is geboren en van wie ten minste één ouder in het buitenland is geboren.

Tweedegeneratieallochtoon: Persoon die in Nederland is geboren en van wie ten minste één ouder in het buitenland is geboren.

\section{Taal thuis}

7. Verdere talen 
8. Hoogste opleiding

9. Hoogste opleiding van ouders

10. Richting van opleiding

(indien van toepassing; van respondent, niet van ouders)

11. Beroep

(indien van toepassing)

12. Werkervaring in jaren (indien van toepassing)
Geen onderwijs

Basisonderwijs

$\square$ Special onderwijs (bijvoorbeeld sbo of praktijkonderwijs)

$\square$ Lbo, mavo, vmbo, mbo niveau 1, eerste 3 jaren van havo/vwo

$\square$ Mbo niveau 2 of hoger, havo, vwo

Hbo of universiteit

$\square$ Geen onderwijs

Basisonderwijs

$\square$ Special onderwijs (bijvoorbeeld sbo of praktijkonderwijs)

$\square$ Lbo, mavo, vmbo, mbo niveau 1, eerste 3 jaren van havo/vwo

$\square$ Mbo niveau 2 of hoger, havo, vwo

$\square$ Hbo of universiteit

Onbekend 
13. Burgerlijke staat

\section{Samenstelling huishouden}

5. Hoogste opleiding van partner

(indien van toepassing) $\square$ Ongehuwd (nooit gehuwd en nooit geregistreerd partner geweest)

Gehuwd (wettig gehuwd of geregistreerd partnerschap)

Verweduwd (verweduwd na wettig huwelijk of partnerschap)

Gescheiden (gescheiden na wettig huwelijk of partnerschap)

$\square$ Eenpersoonshuishouden

$\square$ Eenoudergezin met minimaal een minderjarig kind

$\square$ Paar met minimaal een minderjarig kind

$\square$ Overig meerpersoonshuishouden met kinderen

Paar zonder kinderen

$\square$ Overig meerpersoonshuishouden zonder kinderen (Namelijk:

$\square$ Geen onderwijs

Basisonderwijs

$\square$ Special onderwijs (bijvoorbeeld sbo of praktijkonderwijs)

$\square$ Lbo, mavo, vmbo, mbo niveau 1, eerste 3 jaren van havo/vwo

Mbo niveau 2 of hoger, havo, vwo

$\square$ Hbo of universiteit

Onbekend

Aantal:

Leeftijd: 



\section{Appendix B: Survey for Citizens in Cluster Randomised Trial}

\section{Vragenlijst over uw ervaringen met het gesprek}

Beste deelnemer,

Welkom bij dit onderzoek naar uw tevredenheid met het gesprek. We waarderen uw deelname zeer. Dit is een onderzoek van de Universiteit Maastricht en wordt uitgevoerd door Mira Bierbaum, Prof. Franziska Gassmann, Dr. Eleonora Nillesen en Prof. Fred Zijlstra. ${ }^{9}$

Samen met Sociale Zaken Maastricht Heuvelland doen we dit onderzoek om te kijken hoe men gesprekken tussen $\mathrm{u}$ als burger en medewerkers van Sociale Zaken Maastricht Heuvelland kan verbeteren.

We zijn geïnteresseerd in hoe u deze afspraak hebt ervaren, en wat uw verwachtingen zijn in relatie tot het zoeken van werk. Daarnaast hebben we nog enkele vragen waarbij we een algemene indruk willen krijgen van hoe u zich voelt. Er zijn geen goede of foute antwoorden: het gaat om uw indruk.

Het invullen van de vragenlijst duurt gemiddeld 15-30 minuten. Zodra u klaar bent, kunt $\mathrm{u}$ de vragenlijst in de envelop doen en deze bij de balie afgeven. U ontvangt van de medewerker aan de balie meteen uw cadeaubon van 5 euro.

Uw antwoorden worden anoniem verwerkt. Dat betekent dat niemand, ook Sociale Zaken en haar medewerkers, inzicht krijgt in uw antwoorden. Niemand behalve het onderzoeksteam zal weten wat $\mathrm{u}$ hebt geantwoord op onderstaande vragen. Alleen de eindresultaten, bijvoorbeeld $60 \%$ antwoordde "Ja" op vraag 35, worden gedeeld met derden. We informeren u graag over de resultaten na afloop van het onderzoek.

Voor vragen kunt $\mathrm{u}$ contact opnemen met:

9 Het onderzoek is goedgekeurd door de Ethische Beoordelingscommissie Psychologie en Neurowetenschappen (Kenmerk ERCPN 176 05_02_2017) van de Universiteit Maastricht. 
Mira Bierbaum

Universiteit Maastricht, Graduate School of Governance

Telefoon: $043-3884404$

E-mail: mira.bierbaum@maastrichtuniversity.nl 


\section{PERSOONLIJKE ACHTERGROND}

1. Wat is uw geslacht? $\bigcirc$ man vrouw

2. Was is uw leeftijd? $\square \square$

3. Wat is uw nationaliteit? $\bigcirc$ Nederlands

anders, namelijk:

4. Is ten minste één van uw $\bigcirc$ nee ouders in het buitenland geboren?

$\bigcirc$ ja, namelijk in:

5. Welke taal spreekt $\mathrm{u}$ thuis $\bigcirc$ Nederlands gewoonlijk?

anders, namelijk:

6. Wat is uw burgerlijke staat? $\bigcirc$ ongehuwd $\bigcirc$ verweduwd

$\bigcirc$ gehuwd $\bigcirc$ gescheiden

7. Wat is uw woonsituatie? $\bigcirc$ ik woon alleen

$\bigcirc$ ik woon samen met mijn partner

$\bigcirc$ ik woon als alleenstaand ouder, samen met mijn kind(eren)

$\bigcirc \mathrm{ik}$ woon samen met partner en kind(eren)

anders, namelijk: 


\section{UITKERING}

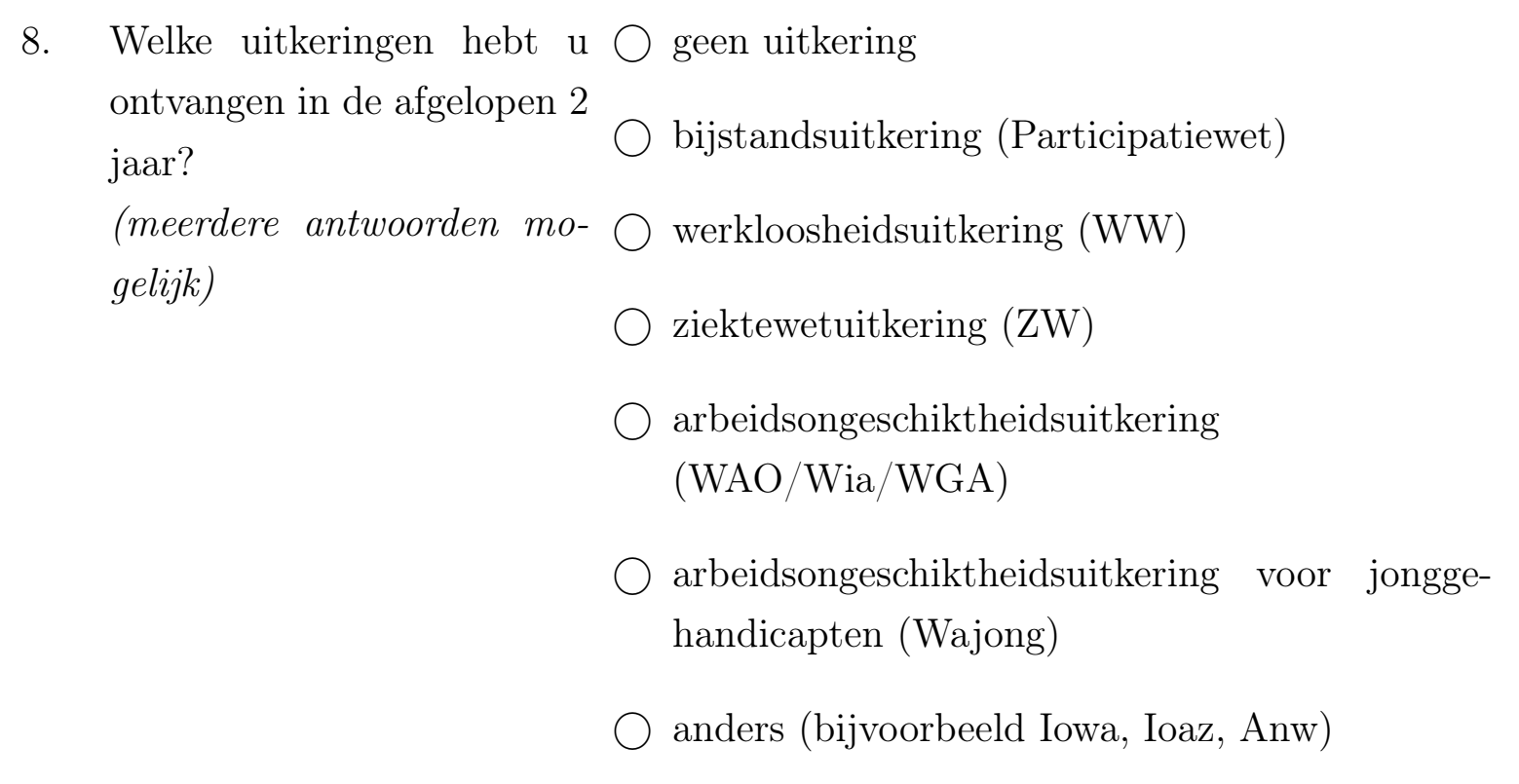




\section{OPLEIDING EN ARBEIDSVERLEDEN}

9. Wat is de hoogste opleiding $\bigcirc$ geen onderwijs

die $\mathrm{u}$ hebt afgerond?

basisonderwijs

speciaal onderwijs (bijvoorbeeld sbo of praktijkonderwijs)

lbo, mavo, vmbo, mbo niveau 1, eerste 3 jaren van havo en vwo

mbo niveau 2 of hoger, havo, vwo

hbo of universiteit

10. Hebt $\mathrm{u}$ in de afgelopen $2 \bigcirc$ ja, de gehele periode jaar betaald of onbetaald werk gedaan?

ja, maar niet de gehele 2 jaar

$\bigcirc$ nee, ik heb de afgelopen twee jaar niet gewerkt

$\rightarrow$ ga naar vraag 12

$\bigcirc$ nee, ik heb nooit gewerkt $\rightarrow$ ga naar vraag 12

11. Wat voor betaald of onbe- $\bigcirc$ loondienst met een vast contract taald werk deed $\mathrm{u}$ in de afgelopen 2 jaar?

loondienst met een tijdelijk contract

(meerdere antwoorden mogelijk)

$\bigcirc$ als uitzendkracht

zelfstandige zonder personeel (zzp'er)

ondernemer met personeel

$\bigcirc$ werk in de vorm van een groeibaan

werk met behoud van uitkering

vrijwilliger of mantelzorger

anders, namelijk 


\section{TEVREDENHEID OVER HET GESPREK}

\begin{tabular}{|c|c|c|c|c|c|c|}
\hline \multirow[t]{7}{*}{12.} & $\begin{array}{l}\text { In hoeverre bent } u \text { het eens of } \\
\text { oneens met de volgende } \\
\text { stellingen over hoe } u \text { het } \\
\text { gesprek heeft ervaren? }\end{array}$ & $\begin{array}{l}\text { hele- } \\
\text { maal } \\
\text { oneens }\end{array}$ & oneens & $\begin{array}{l}\text { niet } \\
\text { eens/niet eens } \\
\text { oneens }\end{array}$ & $\begin{array}{l}\text { hele- } \\
\text { maal } \\
\text { eens }\end{array}$ & $\begin{array}{l}\text { niet } \\
\text { van } \\
\text { toepas- } \\
\text { sing }\end{array}$ \\
\hline & $\begin{array}{l}\text { Ik heb het gesprek als } \\
\text { motiverend ervaren. }\end{array}$ & 0 & $\bigcirc$ & 0 & ( & 0 \\
\hline & $\begin{array}{l}\text { Ik heb het gesprek als } \\
\text { belastend ervaren. }\end{array}$ & 0 & $\bigcirc$ & 0 & $\Omega$ & \\
\hline & $\begin{array}{l}\text { Ik heb het gesprek als } \\
\text { gemakkelijk ervaren. }\end{array}$ & 0 & ) & 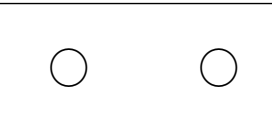 & & 0 \\
\hline & $\begin{array}{l}\text { Ik heb het gesprek als } \\
\text { moeilijk ervaren. }\end{array}$ & 0 & $\cap$ & 0 & & 0 \\
\hline & $\begin{array}{l}\text { Ik heb het gesprek als } \\
\text { ondersteunend ervaren. }\end{array}$ & $\bigcirc$ & 0 & 0 & & 0 \\
\hline & $\begin{array}{l}\text { Ik heb het gesprek als } \\
\text { dreigend ervaren. }\end{array}$ & 0 & $\Omega$ & $\cap$ & & \\
\hline \multirow[t]{7}{*}{13.} & $\begin{array}{l}\text { In hoeverre bent } \mathrm{u} \text { het eens of } \\
\text { oneens met de volgende } \\
\text { stellingen over de inhoud van } \\
\text { het gesprek? }\end{array}$ & $\begin{array}{l}\text { hele- } \\
\text { maal } \\
\text { oneens }\end{array}$ & oneens & $\begin{array}{l}\text { niet } \\
\text { eens/niet eens } \\
\text { oneens }\end{array}$ & $\begin{array}{l}\text { hele- } \\
\text { maal } \\
\text { eens }\end{array}$ & $\begin{array}{l}\text { niet } \\
\text { van } \\
\text { toepas- } \\
\text { sing }\end{array}$ \\
\hline & $\begin{array}{l}\text { Het doel van het gesprek was } \\
\text { voor mij duidelijk. }\end{array}$ & 0 & $\bigcirc$ & 0 & 0 & 0 \\
\hline & Ik vond het gesprek zinvol. & $\bigcirc$ & $\bigcirc$ & $\bigcirc$ & $\bigcirc$ & 0 \\
\hline & $\begin{array}{l}\text { Ik vind de informatie over } \\
\text { mijn uitkering zinvol. }\end{array}$ & $\cap$ & $\curvearrowright$ & $\bigcirc$ & ( & \\
\hline & $\begin{array}{l}\text { Ik vind de informatie over } \\
\text { mijn rechten duidelijk. }\end{array}$ & 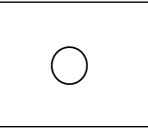 & 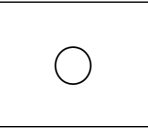 & $\cap$ & & ) \\
\hline & $\begin{array}{l}\text { Ik vind de informatie over } \\
\text { mijn plichten duidelijk. }\end{array}$ & 0 & $\bigcirc$ & $\bigcirc$ & C & 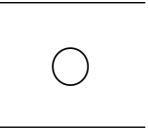 \\
\hline & $\begin{array}{l}\text { Ik vind de informatie over } \\
\text { werk zoeken duidelijk. }\end{array}$ & $\cap$ & 0 & 0 & C & O \\
\hline
\end{tabular}




\begin{tabular}{|c|c|c|c|c|c|}
\hline & $\begin{array}{l}\text { hele- } \\
\text { maal } \\
\text { oneens }\end{array}$ & oneens & $\begin{array}{l}\text { niet } \\
\text { eens/niet eens } \\
\text { oneens }\end{array}$ & $\begin{array}{l}\text { hele- } \\
\text { maal } \\
\text { eens }\end{array}$ & $\begin{array}{l}\text { niet } \\
\text { van } \\
\text { toepas- } \\
\text { sing }\end{array}$ \\
\hline $\begin{array}{l}\text { Ik vind het duidelijk wat de } \\
\text { gemeente voor mij kan doen } \\
\text { bij het vinden van werk. }\end{array}$ & 0 & 0 & 0 & 0 & 0 \\
\hline $\begin{array}{l}\text { Als ik een vraag over mijn } \\
\text { uitkering heb dan weet ik } \\
\text { waar of bij wie ik het } \\
\text { antwoord kan vinden. }\end{array}$ & 0 & 0 & 0 & 0 & 0 \\
\hline $\begin{array}{l}\text { Ik vind dat er vanuit de } \\
\text { sociale dienst voldoende } \\
\text { aandacht is voor mijn } \\
\text { persoonlijke situatie. }\end{array}$ & 0 & 0 & 0 & 0 & 0 \\
\hline
\end{tabular}

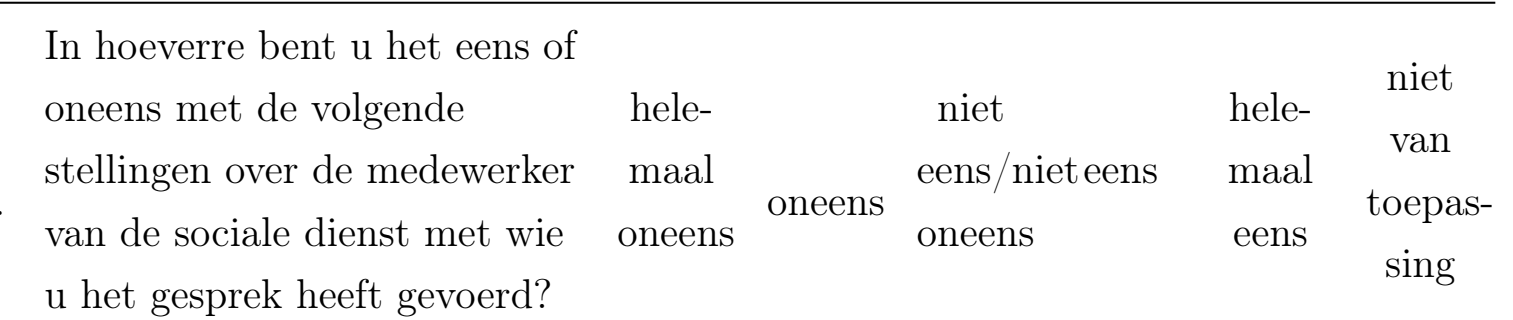

\begin{tabular}{|c|c|c|c|c|c|c|}
\hline De medewerker is vriendelijk. & $\bigcirc$ & $\bigcirc$ & $\bigcirc$ & $\bigcirc$ & $\bigcirc$ & $\bigcirc$ \\
\hline De medewerker is deskundig. & $\bigcirc$ & $\bigcirc$ & $\bigcirc$ & 0 & $\bigcirc$ & $\bigcirc$ \\
\hline De medewerker is duidelijk. & $\bigcirc$ & 0 & 0 & $\bigcirc$ & O & $\bigcirc$ \\
\hline $\begin{array}{l}\text { De medewerker is } \\
\text { toegankelijk. }\end{array}$ & $\bigcirc$ & $\bigcirc$ & $\bigcirc$ & $\bigcirc$ & b & $\bigcirc$ \\
\hline $\begin{array}{l}\text { De medewerker is } \\
\text { onbevooroordeeld. }\end{array}$ & $\bigcirc$ & $\bigcirc$ & $C$ & C & $\bigcirc$ & $\bigcirc$ \\
\hline $\begin{array}{l}\text { De medewerker toont } \\
\text { interesse. }\end{array}$ & $\bigcirc$ & $\bigcirc$ & $\bigcirc$ & C & & ) \\
\hline $\begin{array}{l}\text { De medewerker begrijpt mijn } \\
\text { persoonlijke situatie. }\end{array}$ & $\bigcirc$ & $\bigcirc$ & O & $\cap$ & & r \\
\hline $\begin{array}{l}\text { De medewerker houdt } \\
\text { rekening met mijn } \\
\text { persoonlijke situatie. }\end{array}$ & $\bigcirc$ & $\bigcirc$ & $\bigcirc$ & $\bigcirc$ & ) & $\bigcirc$ \\
\hline $\begin{array}{l}\text { De medewerker neemt mij } \\
\text { serieus. }\end{array}$ & $\bigcirc$ & $\bigcirc$ & $\bigcirc$ & $\bigcirc$ & 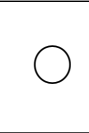 & $\bigcirc$ \\
\hline
\end{tabular}


Hoe beoordeelt u uw

15.

$\begin{array}{lllllllllll}\text { gesprek vandaag in zijn } & 1 & 2 & 3 & 4 & 5 & 6 & 7 & 8 & 9 & 10 \\ \text { geheel? } \\ \begin{array}{l}\text { U kunt dit aangeven met } \\ \text { een rapportcijfer (waarbij } \\ \text { een } 1 \text { 'heel slecht' is en een } \\ 10\end{array} \text { 'heel goed'). }\end{array}$

16.

Hebt u nog aanvullende opmerkingen?

Hieronder kunt u verdere opmerkingen opschrijven, als u dat wilt, over uw indruk van het gesprek en de medewerker. 


\section{ZOEKEN NAAR WERK}

17. Bent u op dit moment door de so- $\bigcirc$ ja ciale dienst vrijgesteld van de verplichting om naar werk te zoeken?

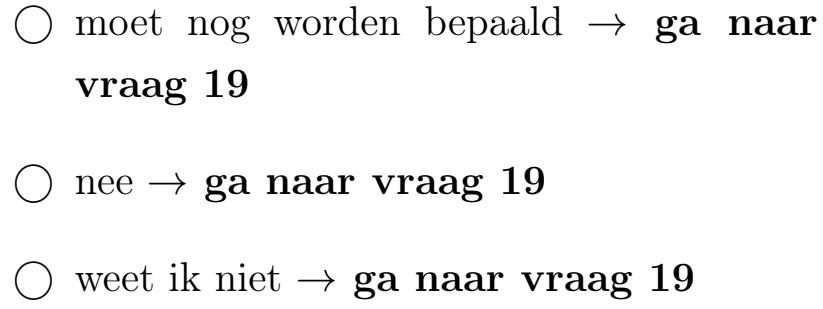

18. Waarom bent $\mathrm{u}$ op dit moment $\bigcirc$ ik ben arbeidsongeschikt door de sociale dienst vrijgesteld van de verplichting om naar werk te zoeken?

$\bigcirc$ ik ben vrijgesteld vanwege sociale omstandigheden

$\bigcirc$ ik doe mantelzorg

ik heb (een) kind(eren) jonger dan 5 jaar

anders, namelijk

$\rightarrow$ ga in ieder geval verder naar vraag 22

19. De volgende stellingen gaan over het zoeken naar werk en mogelijke uitslagen. Beoordeel hoe zeker $\mathrm{u}$ bent dat $\mathrm{u}$ de volgende dingen kan doen of bereiken.

Geef aan hoeveel vertrouwen $u$ heeft dat $u$ de volgende dingen kan uitvoeren of bereiken door een cijfer te geven van 1 (geheel geen vertrouwen) tot 5 (volledig vertrouwen).

$\begin{array}{llllll}\text { Ik kan mijn omgeving } & 1 & 2 & 3 & 4 & 5\end{array}$

(bijvoorbeeld familie, vrienden,

kennissen) gebruiken om werk te krijgen.

\begin{tabular}{lccccc}
\hline Ik kan een CV voorbereiden, & 1 & 2 & 3 & 4 & 5 \\
waardoor ik uitgenodigd word & $\bigcirc$ & $\bigcirc$ & $\bigcirc$ & $\bigcirc$ & $\bigcirc$ \\
voor sollicitatie gesprekken. & & & & & \\
\hline Ik kan tijdens een & 1 & 2 & 3 & 4 & 5 \\
sollicitatiegesprek indruk maken & $\bigcirc$ & $\bigcirc$ & $\bigcirc$ & $\bigcirc$ & $\bigcirc$ \\
op de interviewer. & & & & & \\
\hline
\end{tabular}




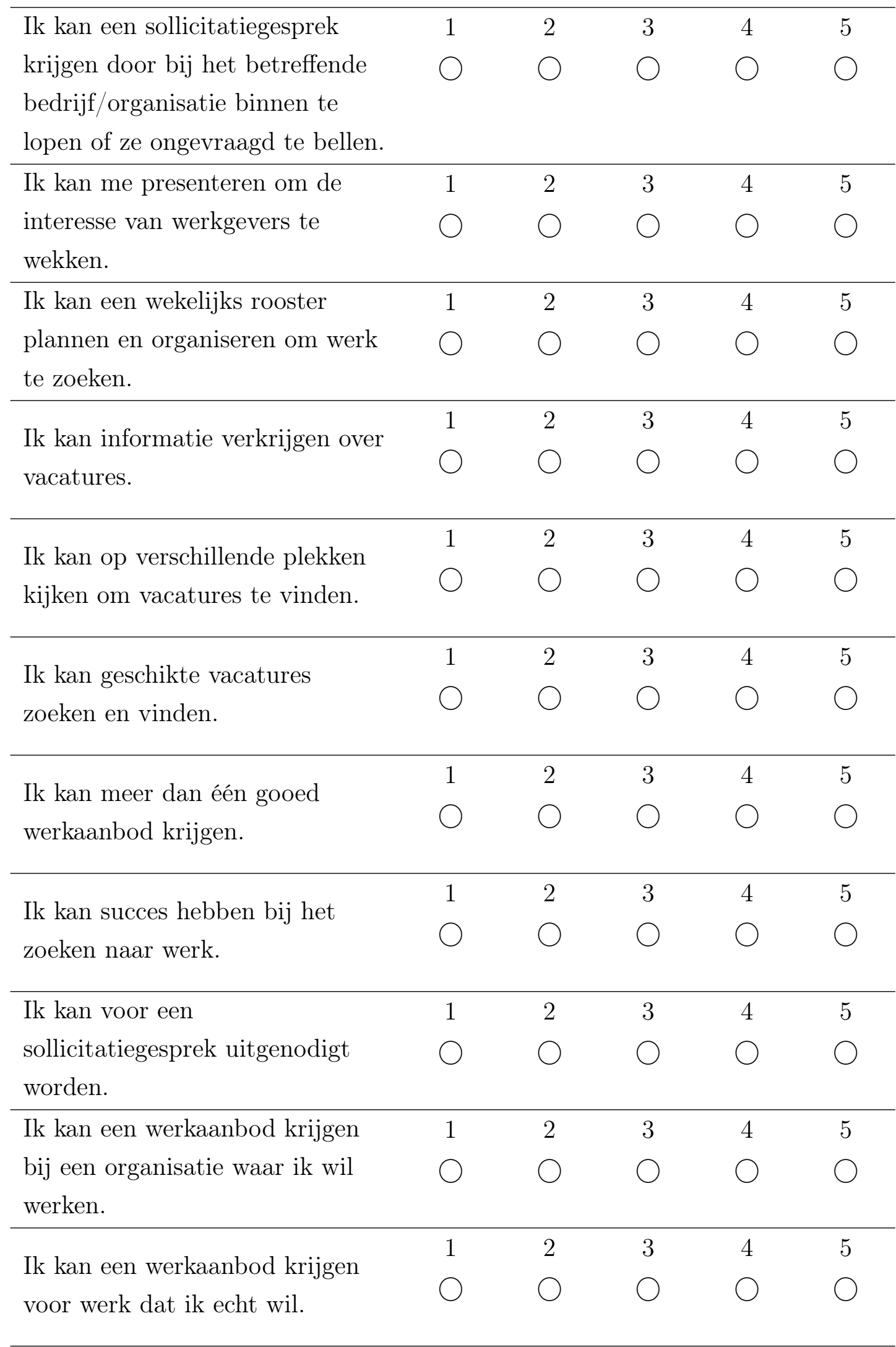




\begin{tabular}{lccccc}
\hline $\begin{array}{l}\text { Ik kan zo snel mogelijk werk } \\
\text { krijgen. }\end{array}$ & 1 & 2 & 3 & 4 & 5 \\
& & $\bigcirc$ & $\bigcirc$ & $\bigcirc$ & $\bigcirc$ \\
Ik kan werk met een goed salaris & 1 & 2 & 3 & 4 & 5 \\
krijgen. & $\bigcirc$ & $\bigcirc$ & $\bigcirc$ & $\bigcirc$ & $\bigcirc$
\end{tabular}

20. Hoeveel uur denkt $\mathrm{u}$ gemiddeld $\bigcirc 0$ uur per week per werk te gaan besteden aan het zoeken van werk? Maak een in$1-5$ uur per week schatting voor de komende twee $\bigcirc$ 6-10 uur per week maanden.

11-15 uur per week

16-20 uur per week

21 uur of meer per week

21. Hoeveel inspanning denkt u $\bigcirc$ geen inspanning gemiddeld per werk te gaan besteden aan het zoeken van weinig inspanning werk? Maak een inschatting voor de komende twee maanden.
niet veel, niet weinig inspanning
$\bigcirc$ veel inspanning
heel veel inspanning 


\section{GEMOEDSTOESTAND}

22. In hoeverre bent $\mathrm{u}$ het eens of oneens met de volgende stellingen over hoe u zich op dit moment voelt?

$U$ kunt dit aangeven op een schaal van 1 (helemaal oneens) tot 9 (helemaal eens).

$\begin{array}{lllllllll}1 & 2 & 3 & 4 & 5 & 6 & 7 & 8 & 9\end{array}$

Op dit moment voel ik me trots.

Op dit moment voel ik me

$\bigcirc \bigcirc \bigcirc \bigcirc \bigcirc \bigcirc \bigcirc \bigcirc \bigcirc$
zelfverzekerd.

$\begin{array}{lllllllll}1 & 2 & 3 & 4 & 5 & 6 & 7 & 8 & 9\end{array}$

$\bigcirc \bigcirc \bigcirc \bigcirc \bigcirc \bigcirc \bigcirc \bigcirc \bigcirc$

Over het algemeen voel ik me op dit moment positief over mezelf.

$\begin{array}{lllllllll}1 & 2 & 3 & 4 & 5 & 6 & 7 & 8 & 9 \\ \bigcirc & \bigcirc & \bigcirc & \bigcirc & \bigcirc & \bigcirc & \bigcirc & \bigcirc & \bigcirc\end{array}$

\begin{tabular}{lccccccccc}
\hline & 1 & 2 & 3 & 4 & 5 & 6 & 7 & 8 & 9 \\
Ik voel me succesvol. & $\bigcirc$ & $\bigcirc$ & $\bigcirc$ & $\bigcirc$ & $\bigcirc$ & $\bigcirc$ & $\bigcirc$ & $\bigcirc$ & $\bigcirc$
\end{tabular}

Op dit moment voel ik me

$\begin{array}{lllllllll}1 & 2 & 3 & 4 & 5 & 6 & 7 & 8 & 9\end{array}$
tevreden over mezelf.

$\begin{array}{lccccccccc}\text { Op dit moment voel ik me goed } & 1 & 2 & 3 & 4 & 5 & 6 & 7 & 8 & 9 \\ \text { over mezelf. } & \bigcirc & \bigcirc & \bigcirc & \bigcirc & \bigcirc & \bigcirc & \bigcirc & \bigcirc & \bigcirc\end{array}$

\begin{tabular}{lccccccccc}
\hline Ik voel heel erg dat ik een & 1 & 2 & 3 & 4 & 5 & 6 & 7 & 8 & 9 \\
waardevol iemand ben. & $\bigcirc$ & $\bigcirc$ & $\bigcirc$ & $\bigcirc$ & $\bigcirc$ & $\bigcirc$ & $\bigcirc$ & $\bigcirc$ & $\bigcirc$ \\
\hline
\end{tabular}

Op dit moment voel ik me niet overtuigd van mezelf.

$\begin{array}{lllllllll}1 & 2 & 3 & 4 & 5 & 6 & 7 & 8 & 9 \\ \bigcirc & \bigcirc & \bigcirc & \bigcirc & \bigcirc & \bigcirc & \bigcirc & \bigcirc & \bigcirc\end{array}$

Op dit moment voel ik me

$\begin{array}{lllllllll}1 & 2 & 3 & 4 & 5 & 6 & 7 & 8 & 9 \\ \bigcirc & \bigcirc & \bigcirc & \bigcirc & \bigcirc & \bigcirc & \bigcirc & \bigcirc & \bigcirc\end{array}$
ongemakkelijk.

Op dit moment voel ik me

$\begin{array}{ccccccccc}1 & 2 & 3 & 4 & 5 & 6 & 7 & 8 & 9 \\ \bigcirc & \bigcirc & \bigcirc & \bigcirc & \bigcirc & \bigcirc & \bigcirc & \bigcirc & \bigcirc\end{array}$
vernederd. 


\begin{tabular}{|c|c|c|c|c|c|c|c|c|}
\hline $\begin{array}{l}\text { Op dit moment voel ik me } \\
\text { beschaamd. }\end{array}$ & $\begin{array}{ll}1 & 2 \\
\bigcirc & \bigcirc\end{array}$ & 3 & 4 & 5 & 6 & 7 & 8 & $\begin{array}{l}9 \\
\bigcirc\end{array}$ \\
\hline $\begin{array}{l}\text { Op dit moment voel ik me } \\
\text { verveeld. }\end{array}$ & $\begin{array}{ll}1 & 2 \\
\bigcirc & \bigcirc\end{array}$ & 3 & 4 & 5 & 6 & 7 & 8 & $\begin{array}{l}9 \\
9\end{array}$ \\
\hline $\begin{array}{l}\text { Op dit moment voel ik me } \\
\text { minderwaardig. }\end{array}$ & $\begin{array}{ll}1 & 2 \\
\bigcirc & \bigcirc\end{array}$ & 3 & 4 & 5 & 6 & 7 & 8 & 9 \\
\hline $\begin{array}{l}\text { Op dit moment voel ik me } \\
\text { gefrustreerd en onzeker. }\end{array}$ & $\begin{array}{ll}1 & 2 \\
\bigcirc & \bigcirc\end{array}$ & $\begin{array}{l}3 \\
0\end{array}$ & & 5 & 6 & 7 & $\begin{array}{l}8 \\
0\end{array}$ & $\begin{array}{l}9 \\
\bigcirc\end{array}$ \\
\hline
\end{tabular}

23. Kruis het beeld aan wat de relatie tussen $u$ en de maatschappij het best beschrijft.

In ieder beeld, de kring aan de linkerkant staat voor $u(U)$ en de kring aan de rechterkant staat voor de maatschappij $(M)$. Met maatschappij bedoelen wij alle mensen samen en hoe ze met elkaar omgaan.
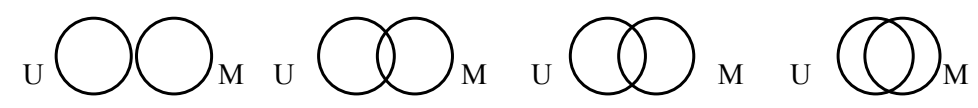

$\mathrm{U}$
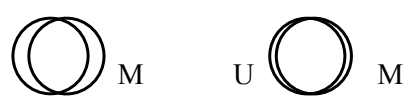

○

○

○

$\circ$

○

○ 
24. Op de volgende pagina's ziet $u$ meerdere patronen waar telkens een deel ontbreekt. Onder ieder patroon ziet $\mathrm{u}$ zes of acht delen. Kruis het deel aan wat in het patroon past.

Bijvoorbeeld, in dit patroon ontbreekt een deel. Er zijn zes mogelijke delen onder het patroon. Deel 4 past in het patroon. Dus, u kruist nummer 4 aan.

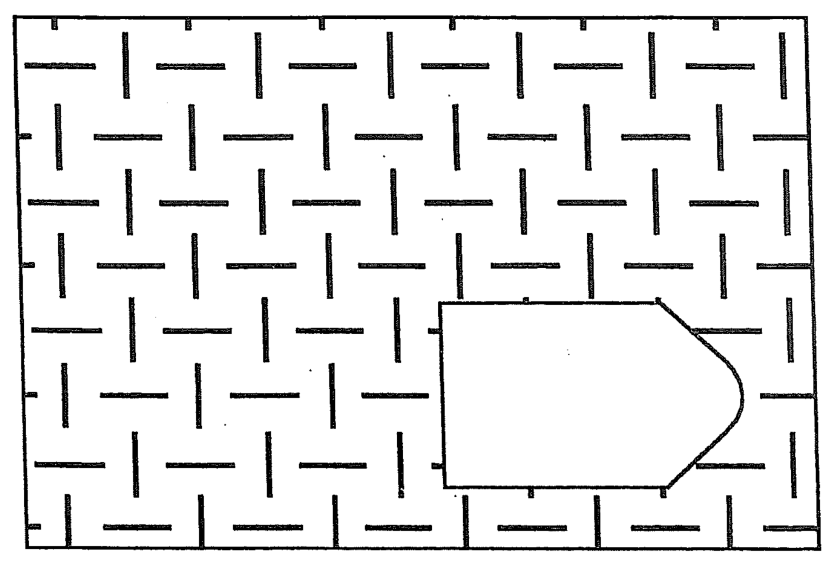

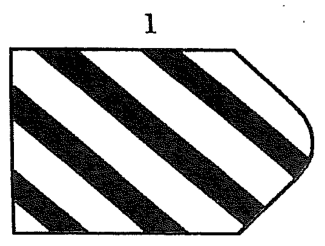

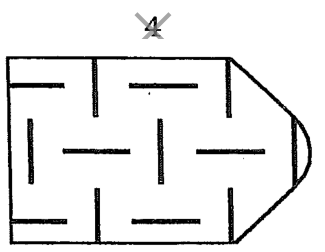

2

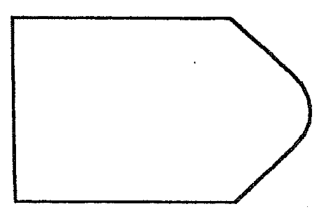

5

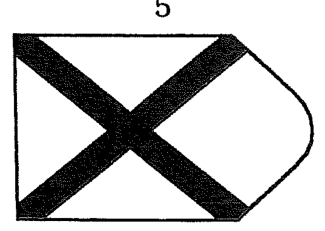

3
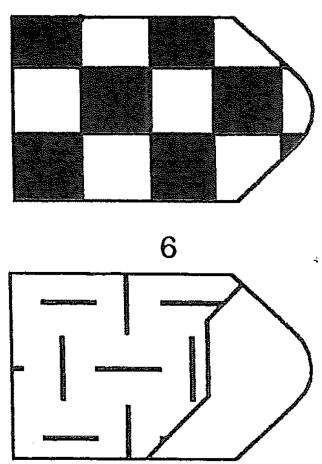

[The following items of the Standard Raven's Matrices were included in the questionnaire: $2,11,19,24,28,36,43,48,49,53,55,58$. 


\section{TOT SLOT}

25. Hieronder kunt $\mathrm{u}$, als $\mathrm{u}$ wilt, aanvullende opmerkingen opschrijven over het gesprek, uw uitkering, of de sociale dienst en/of de medewerker van de sociale dienst.

26. Hieronder kunt $\mathrm{u}$, als $\mathrm{u}$ wilt, opmerkingen over de vragenlijst van dit onderzoek opschrijven. 



\section{Appendix C: Factorial Survey for Activation Workers}

Beste klantmanager,

Hartelijk dank dat $u$ wilt deelnemen aan onze enquête in het kader van een onderzoek van de Universiteit Maastricht. Dit onderzoek wordt uitgevoerd door Mira Bierbaum, Prof. Franziska Gassmann en Prof. Fred Zijlstra. Het onderzoek is goedgekeurd door de Ethical Review Committee Inner City Faculties (Kenmerk ERCIC_072_04_04_2018) van de Universiteit Maastricht.

In dit onderzoek zijn wij geïnteresseerd in hoe klantmanagers tot besluiten komen en welke overwegingen daarbij een rol spelen. Door gegevens te verzamelen ten aanzien van overeenkomsten en verschillen in hoe klantmanagers hun discretionaire bevoegdheid gebruiken om burgers te activeren, is het mogelijk om inzicht te krijgen in de huidige uitvoeringspraktijk. Dit onderzoek levert een bijdrage aan de discussie over de betekenis van vakmanschap in het participatiedomein en hoe de professionaliteit kan worden ontwikkeld. Daarom wordt dit onderzoek ondersteund door de gemeente, lees Sociale Zaken Maastricht Heuvelland.

Tegen deze achtergrond zouden wij in deze enquête graag iets meer te weten komen over hoe $\mathrm{u}$ tot besluiten komt. Wij doen dit aan de hand van een aantal fictieve beschrijvingen van burgersituaties. Vervolgens zijn we geïnteresseerd in hoe u de kansen van deze burgers inschat om werk te vinden. Verder vragen wij u om keuzes te maken hoe $\mathrm{u}$ de casus verder zou aanpakken. Bovendien hebben wij nog enkele vragen over uw achtergrond en over uw eigen overtuigingen met betrekking tot uw werk en met welk beeld van de burger u dat doet. Er zijn geen goede of foute antwoorden. Het gaat ons uitsluitend om uw mening.

Uw deelname aan het onderzoek is vrijwillig. Niettemin is het belangrijk dat zo veel mogelijk collega klantmanagers meedoen om representativiteit en betrouwbaarheid van de resultaten te bereiken. Het invullen van de vragenlijst duurt gemiddeld 20 tot 30 minuten. Helaas kunt u een gedeeltelijk ingevulde vragenlijst niet opslaan en daarna teruggaan - dit in verband met het feit dat wij uw anonimiteit willen bewaren en geen persoonlijke links of cookies gebruiken. Zolang $u$ het browservenster niet

sluit, is het echter mogelijk om te pauzeren en de enquête ook iets later verder in te 
vullen.

Uw antwoorden worden anoniem opgeslagen en verwerkt. Andere medewerkers of het management van Sociale Zaken Maastricht Heuvelland hebben geen toegang tot de gegevens. Na afloop van het onderzoek informeren wij u graag over de resultaten. Als blijk van waardering verloten wij vijf VVV bonnen ter waarde van $€ 20$ per stuk onder alle deelnemers aan het onderzoek.

Voor vragen kunt $\mathrm{u}$ contact opnemen met:

Mira Bierbaum

Universiteit Maastricht, Graduate School of Governance

Telefoon: $043-3884404$

E-mail: mira.bierbaum@maastrichtuniversity.nl

\section{TOESTEMMINGSVERKLARING}

Ik ben geïnformeerd over het onderzoek. Ik heb de mogelijkheid gekregen om vragen te stellen over het onderzoek. Ik heb gelegenheid gekregen om over het onderzoek na te denken en mijn deelname is geheel vrijwillig. Ik heb te allen tijde het recht de verleende toestemming weer in te trekken en mijn deelname aan het onderzoek stop te zetten zonder opgaaf van reden.

Stemt $\mathrm{u}$ ermee in om aan het onderzoek deel te nemen? Door op Ja te klikken, gaat $\mathrm{u}$ ermee akkoord dat $\mathrm{u}$ bereid bent de vragen in deze enquête te beantwoorden. 


\section{VIGNETTES}

In wat volgt tonen wij $\mathrm{u}$ twaalf fictieve beschrijvingen van burgersituaties. Deze beschrijvingen bevatten telkens korte informatie over geslacht, leeftijd, herkomst, opleiding, werkervaring en houding ten aanzien van werk, gezondheidstoestand, gezinssamenstelling, mantelzorg, schulden en eerder ontvangen uitkeringen.

Op basis van deze beschrijvingen wordt $u$ gevraagd hoe $u$ de kansen inschat dat deze burgers binnen twaalf maanden werk vinden. Naast deze inschattingen vragen wij $\mathrm{u}$ om keuzes te maken hoe $\mathrm{u}$ de casus zou aanpakken: het opleggen van een sollicitatieplicht en wat $\mathrm{u}$ zou inzetten qua verdiepende diagnose, arbeidsmarktbemiddeling, ontwikkeling of arbeidsvervangende voorzieningen.

Er zijn geen goede of foute antwoorden. We zijn alleen geïnteresseerd wat $u$, op basis van deze fictieve (en, toegegeven, beperkte) beschrijvingen normaal gesproken zou voorstellen. Het kan zo zijn dat u niet met alle casussen bekend bent vanuit uw dagelijkse werk. In deze gevallen vragen wij u niettemin om zo goed mogelijk een inschatting te geven.

Nog een korte toelichting op een aantal gebruikte begrippen: Alle burgers in de omschreven situaties hebben geen inkomen of spaargeld en hebben op dit moment een PW-uitkering. Het middelbaar onderwijs omvat ook MBO en praktijkonderwijs. Het hoger onderwijs omvat $\mathrm{HBO}$ en WO. Als er sprake is van geestelijke of lichamelijke problemen, dan kunt $\mathrm{u}$ aannemen dat de burger onder behandeling van een arts is en/of medicijnen gebruikt.

1. Voorbeeld van een vignette, twaalf vignettes per deelnemer:

Een man van 35 jaar heeft nooit een bijstandsuitkering gehad. Hij heeft geen schulden.

De man is allochtoon en spreekt vloeiend Nederlands. Hij leeft alleen. De man heeft geen problemen qua gezondheid. Op dit moment doet de man vrijwilligerswerk.

De man heeft de basisschool afgerond, maar heeft nog bijna geen werkervaring opgedaan. Hij toont weinig motivatie om werk te vinden.

2. In uw dagelijkse werk, bent $\mathrm{u}$ bekend met een dergelijke casus?

$\mathrm{Ja}$

Nee 
3. Op een schaal van 0 tot 100 , hoe schat $\mathrm{u}$ de kansen in dat deze burger binnen twaalf maanden werk vindt?

U kunt dit aangeven door de schuifregelaar te slepen naar de gewenste positie.

0

100

(heel onwaar-

(heel waarschijnlijk) schijnlijk)

4. Zou u deze burger een sollicitatieplicht (inclusief inschrijving bij Podium24) opleggen?

$\bigcirc \mathrm{Ja}$

$\bigcirc$ Nee

5. Zou u voor deze burger een verdiepende diagnose zoals TWB of Annex (bedrijfsarts of bedrijfspsycholoog) inzetten?

$\mathrm{Ja}$

$\bigcirc$ Nee

6. Welk soort arbeidsbemiddeling zou u inzetten?

Sollicitatietraining

Project $45+$

Geen

7. Welk soort ontwikkelingsmogelijkheid zou u inzetten?

Proefplaatsing/stage/groeibaan/werken met behoud van uitkering

Scholing/training/taalcursus

Jobcoaching

Geen 
8. Welk soort arbeidsvervangende activiteiten zou u inzetten?

Sociale activering

$\bigcirc$ Beschut werk

$\bigcirc$ Dagbesteding

$\bigcirc$ Geen

9. Hebt u nog aanvullende opmerkingen met betrekking tot deze casus? 


\section{JOB DESIGN}

10. Waar werkt $\mathrm{u}$ op dit moment?

Intake

Actief bestand

$\bigcirc$ Specialist (45+, werken met behoud van uitkering, wijkservicepunt, bbz, bijzondere bijstand, arbeidsdeskundige)

Jongerenteam

Anders, namelijk:

11. Wat is de hoofdtaak van uw werk? (meerdere antwoorden mogelijk)

Intake

Begeleiding

Specialist

Anders, namelijk:

12. Wat is uw belangrijkste doelgroep?

Burgers met een kleine afstand tot de arbeidsmarkt

$\bigcirc$ Burgers met een grote afstand tot de arbeidsmarkt

$\bigcirc$ Gemengde doelgroep

13. Hoeveel uur werkt u per week?

14. Voor hoeveel burgers was u (mede-)verantwoordelijk in de maand mei 2018 ?

Gelieve ook burgers met wie u geen contact had in mei 2018, maar die wel onder uw (mede-)verantwoordelijkheid vallen, mee te tellen. 


\section{WERKWEIJZE EN VOORKEUREN}

De volgende vragen gaan over uw eigen overtuigingen ten aanzien van uw werk en met welk beeld van de burger u dat doet. Dit kan afhankelijk zijn van de specifieke situatie, maar hier zijn wij geïnteresseerd in uw overtuigingen en waarnemingen in het algemeen.

15. Wat vindt $\mathrm{u}$ belangrijk in uw werk?

U kunt in totaal 100 punten verdelen over de volgende vijf doelen. De doelen die voor u het meest belangrijk zijn, geeft u meer punten dan de doelen die voor u minder belangrijk zijn. Het is ook mogelijk om bepaalde doelen hetzelfde aantal punten te geven, of om een doel helemaal geen punten te geven.

Het zorgvuldig en precies uitvoeren van regels en voorschriften:

Het bevorderen van de uitstroom vanuit de uitkering naar werk:

Het aanbieden van diensten die burgers nodig hebben:

Het bevorderen van de eigen kracht en zelfredzaamheid van burgers:

Het aanbieden van diensten die burgers wensen:

16. Wat is uw beeld van de burgers met wie u werkt? Ziet u de burger ...

U kunt opnieuw in totaal 100 punten verdelen over het beeld dat u van burgers hebt.

... als werkloos?

... als behoeftig?

... als leerling?

... als cliënt?

... als coöpererend?

Hoe benadert $\mathrm{u}$ burgers? Wij zijn geïnteresseerd in drie dimensies. Bent $\mathrm{u}$, over het algemeen, eerder coulant of streng? Eerder formeel of informeel? En eerder afstandelijk of betrokken? Zoals eerder aangegeven: dit kan afhankelijk zijn van de specifieke situatie, maar hier zijn wij geïnteresseerd in uw benadering in het algemeen.

$U$ kunt dit aangeven door de schuifregelaar te slepen naar de gewenste positie. Bijvoorbeeld, de schuifregelaar staat nu op een neutrale positie. Hoe strenger u, volgens $u$, burgers benadert, hoe verder sleept $u$ de regelaar naar rechts. 
17.

Coulant

Streng

0

100

18.

Formeel

Informeel

0

100

19.

Afstandelijk

Betrokken

0 100

De volgende vragen gaan over uw omgang met de informatie die een burger u geeft.

U kunt dit opnieuw aangeven door de schuifregelaar naar de gewenste positie te slepen.

20. In hoeverre vindt $u$ het belangrijk veel te weten over de achtergrond en persoonlijke situatie van een burger?

Persoonlijke informatie niet

Persoonlijke belangrijk informatie belangrijk 0 100

21. In hoeverre vertrouwt $\mathrm{u}$ de informatie die een burger geeft, bijvoorbeeld over sollicitaties, inkomsten of werk?

Sceptisch

Vertrouwen 0 100

22. In hoeverre hebt $u$ een uniforme werkwijze die $u$ toepast bij alle burgers? Of past $\mathrm{u}$ eerder maatwerk toe?

Maatwerk

0
Uniform

100 
23.

\begin{tabular}{|c|c|c|c|c|}
\hline $\begin{array}{l}\text { In hoeverre bent } \mathrm{u} \text { het eens of } \\
\text { oneens met de volgende } \\
\text { stellingen? }\end{array}$ & $\begin{array}{l}\text { hele- } \\
\text { maal } \\
\text { oneens }\end{array}$ & oneens & $\begin{array}{l}\text { niet } \\
\text { eens/niet eens } \\
\text { oneens }\end{array}$ & $\begin{array}{l}\text { hele- } \\
\text { maal } \\
\text { eens }\end{array}$ \\
\hline
\end{tabular}

Het monitoren van burgers zou

zich moeten richten op het

naleven van verplichtingen.

Het opleggen van een maatregel

zou afhankelijk moeten zijn van

het effect op het

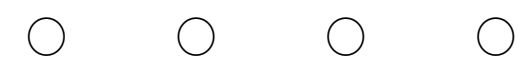

re-integratieproces.

De gelijke behandeling van

burgers zou belangrijker moeten

zijn dan de toepassing van

maatwerk.

Bewezen effectieve methoden op

het gebied van re-integratie

zouden een grote invloed op

mijn beslissingen moeten

hebben.

Het correct uitvoeren van

regelwerk zou belangrijker

moeten zijn dan het bereiken

van resultaten.

24. Sommigen vinden dat de overheid meer verantwoordelijkheid moet nemen om te zorgen dat iedereen krijgt wat hij nodig heeft. Anderen vinden dat elk individu meer verantwoordelijkheid moet nemen om voor zichzelf te zorgen. Hoe kijkt $u$ hier tegenaan?

$U$ kunt dit opnieuw aangeven door de schuifregelaar naar de gewenste positie te slepen.

Mensen moeten meer

verantwoordelijkheid nemen om voor zichzelf te zorgen.
De overheid moet meer verantwoordelijkheid nemen om te zorgen dat iedereen krijgt wat hij nodig heeft.

10 


\section{PERSOONLIJKE ACHTERGROND}

Tenslotte willen wij graag informatie over uw persoonlijke achtergrond.

25. Wat is uw geslacht?

$\bigcirc$ Man

$\bigcirc$ Vrouw

26. Wat is uw leeftijd?

27. Wat is uw nationaliteit?

$\bigcirc$ Nederlands

Anders, namelijk:

28. Is ten minste één van uw ouders in het buitenland geboren?

$\bigcirc$ Nee

Ja, namelijk in:

29. Hebt u kinderen?

$\bigcirc \mathrm{Ja}$

Nee

30. Bent $\mathrm{u}$ zelf of iemand uit uw naaste omgeving ooit langer dan zes maanden werkloos geweest en/of hebt een bijstandsuitkering ontvangen?

$\bigcirc \mathrm{Ja}$

$\bigcirc$ Nee

31. Wat is de richting van uw opleiding? (meerdere antwoorden mogelijk)

Sociaal-juridische Dienstverlening/Hoger Juridisch Onderwijs

Sociaal-agogisch Werk 
$\bigcirc$ Bestuurskunde

$\bigcirc$ Personeel en Arbeid

Anders, namelijk:

32. Wat is het hoogste niveau van uw opleiding?

$\bigcirc$ Universiteit

$\bigcirc \mathrm{HBO}$

$\bigcirc$ Overig

33. Hoeveel jaar werkervaring hebt $\mathrm{u}$ in het participatiedomein?

34. Hieronder kunt $\mathrm{u}$, als $\mathrm{u}$ wilt, aanvullende opmerkingen opschrijven, bijvoorbeeld over uw werk, uw werkwijze of uw omgang met burgers.

35. Hieronder kunt $\mathrm{u}$, als $\mathrm{u}$ wilt, opmerkingen over de vragenlijst van dit onderzoek opschrijven. 



\section{Estimation Results of Factorial Survey Experiment}

Table D.1: Regression model of assessment of labour market chances

\begin{tabular}{|c|c|}
\hline & Labour market chances (0-100) \\
\hline \multicolumn{2}{|l|}{ Citizen characteristics } \\
\hline \multirow[t]{2}{*}{ Male } & $2.374^{*}$ \\
\hline & $(1.194)$ \\
\hline \multirow[t]{2}{*}{35} & $-2.928^{*}$ \\
\hline & $(1.461)$ \\
\hline \multirow[t]{2}{*}{50} & $-6.660^{*}$ \\
\hline & $(1.442)$ \\
\hline \multirow[t]{2}{*}{ Previous benefit receipt } & -0.993 \\
\hline & $(1.184)$ \\
\hline \multirow[t]{2}{*}{ Debts } & $-2.437^{*}$ \\
\hline & $(1.182)$ \\
\hline \multirow[t]{2}{*}{ Foreign background, fluent Dutch } & $2.817+$ \\
\hline & $(1.462)$ \\
\hline \multirow{3}{*}{$\begin{array}{l}\text { Foreign } \\
\text { Dutch }\end{array}$} & $-8.146^{*}$ \\
\hline & \\
\hline & $(1.458)$ \\
\hline \multirow[t]{2}{*}{ Single parent with child $<5$} & $-5.460^{*}$ \\
\hline & $(1.840)$ \\
\hline \multirow[t]{2}{*}{ Single parent with child $>5$} & -2.752 \\
\hline & $(1.846)$ \\
\hline \multirow[t]{2}{*}{ Family with child $<5$} & $-3.298+$ \\
\hline & $(1.852)$ \\
\hline \multirow[t]{2}{*}{ Family with child $>5$} & -1.725 \\
\hline & $(1.856)$ \\
\hline \multirow[t]{2}{*}{ Volunteer work } & $4.374^{*}$ \\
\hline & $(1.440)$ \\
\hline \multirow[t]{2}{*}{ Informal care } & 2.152 \\
\hline & $(1.448)$ \\
\hline Continued on next page & \\
\hline
\end{tabular}


Table D.1 - continued from previous page

\begin{tabular}{|c|c|}
\hline & Labour market chances $(0-100)$ \\
\hline \multirow[t]{2}{*}{ Physical health problems } & $-11.985^{*}$ \\
\hline & $(1.454)$ \\
\hline \multirow[t]{2}{*}{ Mental health problems } & $-14.851^{*}$ \\
\hline & $(1.454)$ \\
\hline \multirow[t]{2}{*}{ Secondary education } & $2.830^{*}$ \\
\hline & $(1.438)$ \\
\hline \multirow[t]{2}{*}{ Higher education } & $5.620^{*}$ \\
\hline & $(1.438)$ \\
\hline \multirow[t]{2}{*}{ Work experience } & $6.065^{*}$ \\
\hline & $(1.180)$ \\
\hline \multirow[t]{2}{*}{ Motivation } & $11.924^{*}$ \\
\hline & $(1.179)$ \\
\hline \multicolumn{2}{|l|}{ Frames of reference } \\
\hline \multirow[t]{2}{*}{ Procedural } & 0.334 \\
\hline & $(0.236)$ \\
\hline \multirow[t]{2}{*}{ Work } & $0.982^{*}$ \\
\hline & $(0.216)$ \\
\hline \multirow[t]{2}{*}{ Care } & 0.291 \\
\hline & $(0.235)$ \\
\hline \multirow[t]{2}{*}{ Learn/change } & $0.346+$ \\
\hline & $(0.202)$ \\
\hline \multicolumn{2}{|l|}{ Workplace characteristics } \\
\hline \multirow[t]{2}{*}{ Intake } & -1.906 \\
\hline & $(8.909)$ \\
\hline \multirow[t]{2}{*}{ Active files } & 0.415 \\
\hline & $(4.340)$ \\
\hline \multirow[t]{2}{*}{ Specialists } & 1.862 \\
\hline & $(5.084)$ \\
\hline \multirow[t]{2}{*}{ Youth } & -2.134 \\
\hline & $(5.133)$ \\
\hline \multirow[t]{2}{*}{ Integrated job design } & 4.869 \\
\hline & $(3.774)$ \\
\hline \multirow[t]{2}{*}{ Mixed target group } & 0.147 \\
\hline & $(3.319)$ \\
\hline \multirow[t]{2}{*}{ Cases per hour } & -0.785 \\
\hline & $(2.668)$ \\
\hline
\end{tabular}

Continued on next page 
Table D.1 - continued from previous page

Labour market chances (0-100)

Worker characteristics

Male

Age

Children

$-5.762^{*}$

$(2.761)$

Unemployment experience

Work experience

$-0.445^{*}$

$(0.198)$

Social administration

$4.658+$

(2.683)

Social work

$6.618+$

$(3.498)$

Personnel and labour

5.078

$(4.550)$

Familiarity with vignette

Constant

19.261

(19.769)

\begin{tabular}{lc}
\hline Standard deviation of $u_{j}$ & $4.708^{*}$ \\
& $(0.835)$ \\
Standard deviation of $\epsilon_{i j}$ & $14.584^{*}$ \\
& $(0.429)$ \\
\hline Number of vignettes & 630 \\
Number of respondents & 52 \\
Log likelihood & -2603.637
\end{tabular}

Notes: ${ }^{*} p<0.05,{ }^{+} p<0.10$. Standard errors are given in brackets.

Dummies for decks are omitted. The reference categories for categorical variables that refer to citizen characteristics are shown in Table 5.2 (the first level of the dimensions respectively). The reference categories for categorical variables that refer to activation worker characteristics are given in Table 5.4 and Table 5.5. 


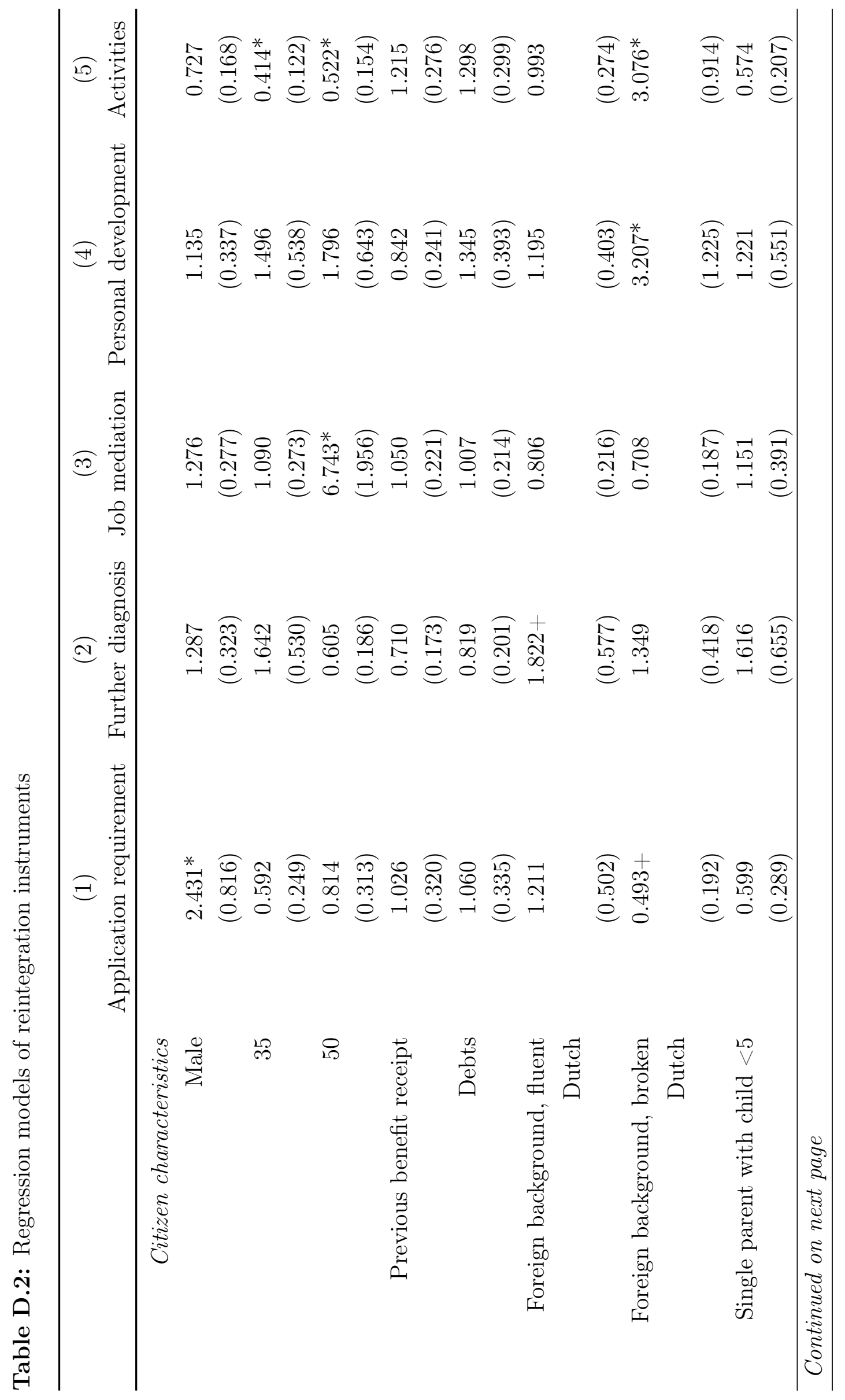




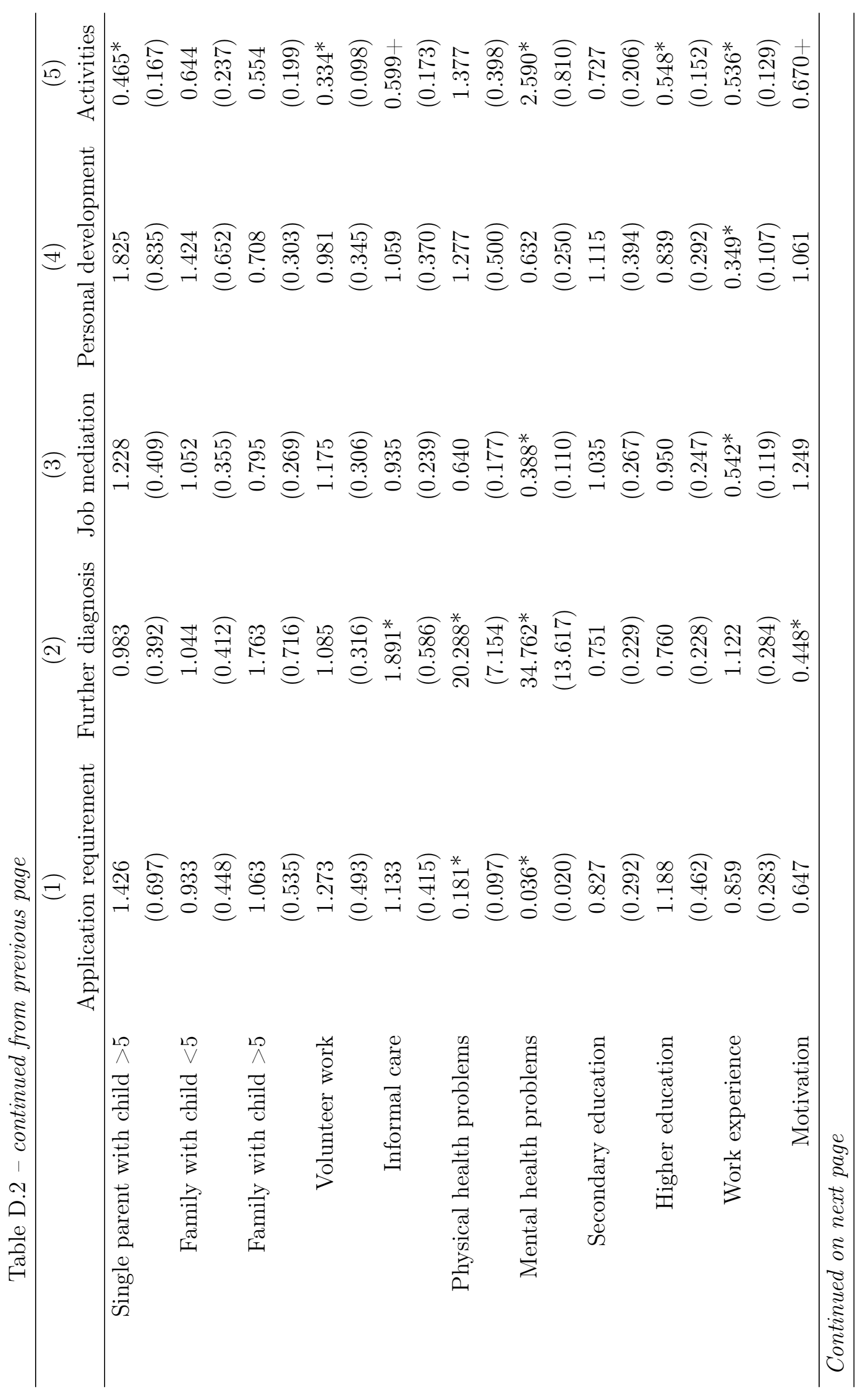




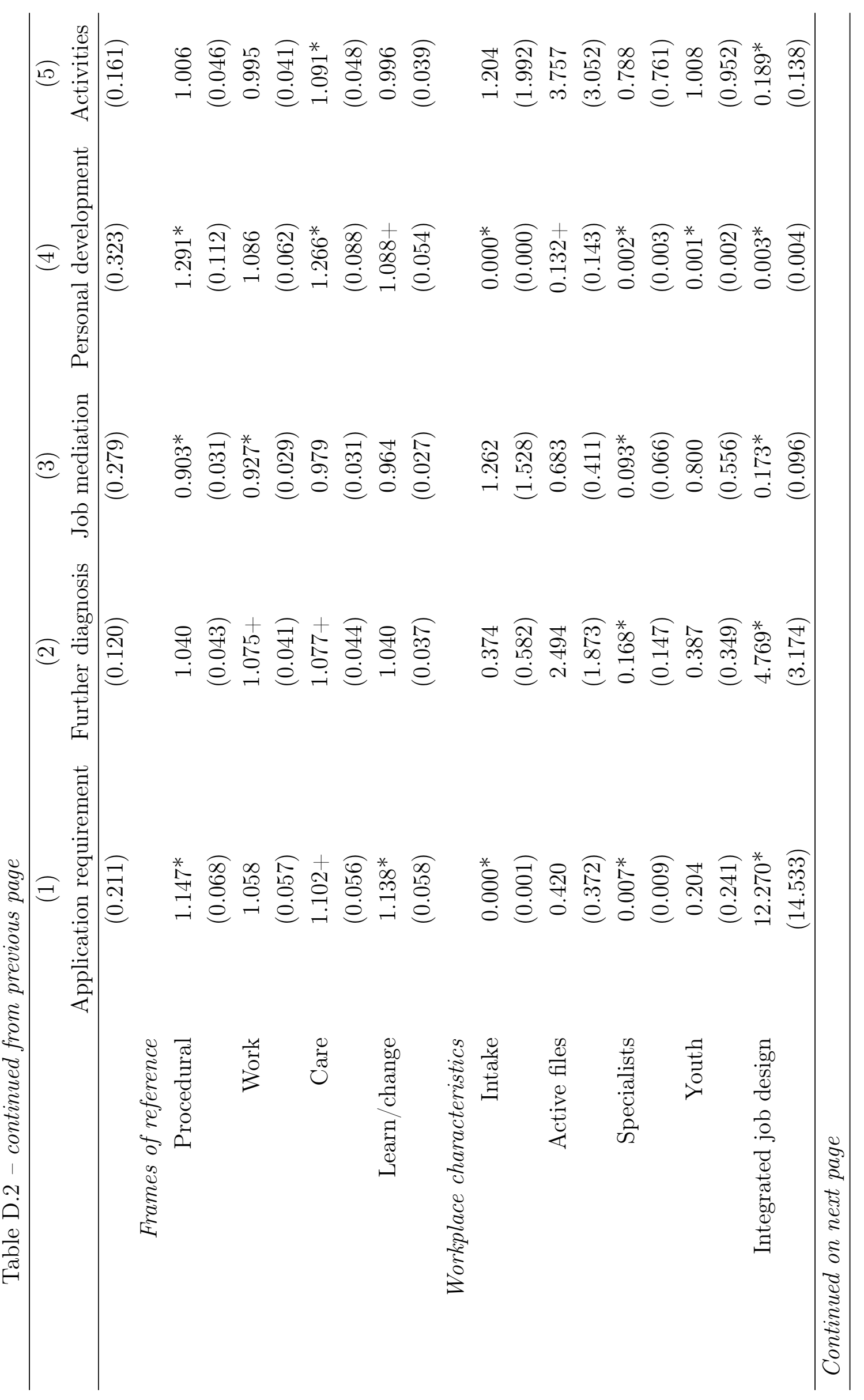




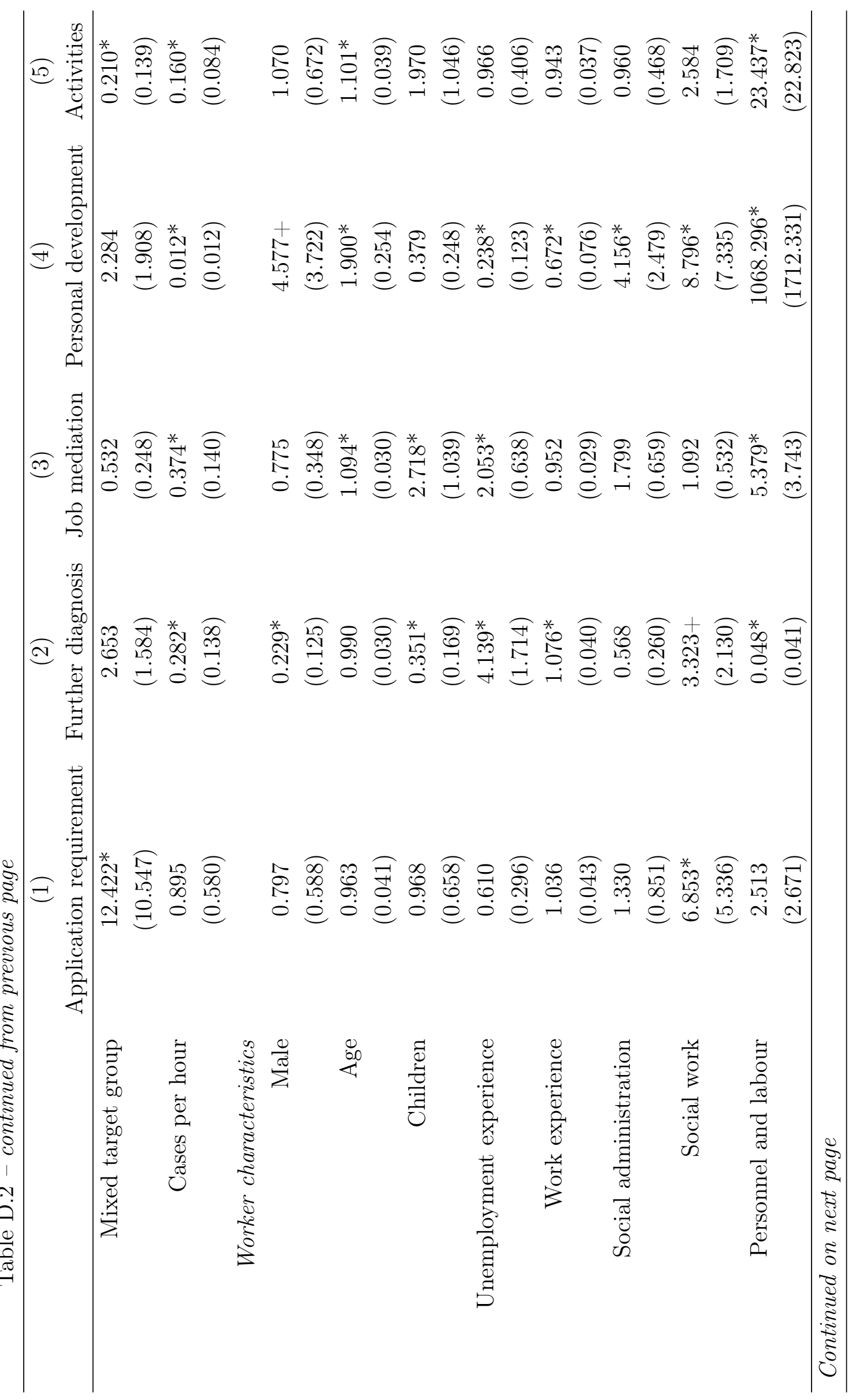




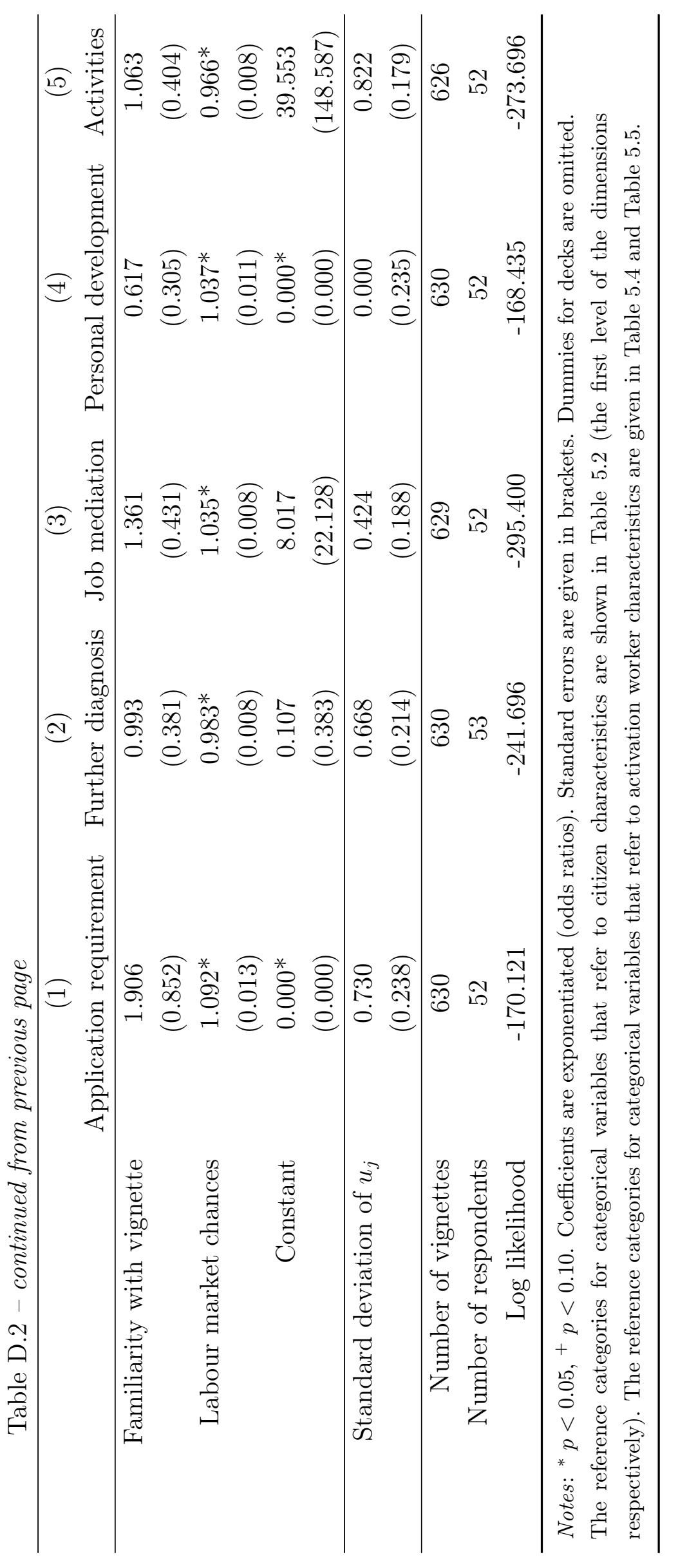




\title{
Samenvatting voor Beleidsmakers
}

\section{Activerend Beleid in de Participatiesamenleving}

\author{
"Wat is uw mensbeeld?"
}

Deze vraag werd meerdere keer gesteld tijdens de behandeling van de Participatiewet en de Wet werk en bijstand in de Eerste Kamer der Staten-Generaal op 24 juni 2014 (Eerste Kamer der Staten-Generaal, 2014). Het doel van de Participatiewet, die vanaf 1 januari 2015 van kracht is, is het bevorderen van de arbeidsmarktdeelname van mensen met arbeidsvermogen, met en zonder beperkingen. Hoe dat kan worden bereikt, daarover verschilden de meningen. Maken mensen financiële afwegingen en beslissen zij op basis daarvan dat ze niet willen meedoen gezien het genereuze sociale zekerheidsstelsel in Nederland? Is het daarom nodig om financiële prikkels in te zetten zodat mensen beslissen om actief aan de arbeidsmarkt deel te nemen, in plaats van passief en afhankelijk te worden? Of zijn de reden voor werkloosheid ingewikkelder en gerelateerd aan een structureel zwakke arbeidsmarkt? Verdienen deze mensen daarom steun en compassie? Gaat het hier over klaplopers en profiteurs of over mensen die zijn gevangen in ongelukkige omstandigheden?

Dit debat in de Eerste Kamer wierp talloze vragen op die controversieel waren en vaak tot op de dag van vandaag tot een verhitte discussie leiden. De aanleiding van dit proefschrift waren deze debatten die vijf jaar geleden werden gevoerd - niet alleen in Nederland, maar ook bijvoorbeeld in het Verenigd Koninkrijk; en, niet alleen in beleidskringen, maar ook onder wetenschappers. In het licht van deze debatten begon dit onderzoek met de volgende vraagstellingen: Welk soort veronderstellingen liggen ten grondslag aan het ontwerp van de Participatiewet en welke implicaties heeft dit voor burgers? Kan het ooit "zwart of wit" zijn of verhindert deze manier van denken een dieper inzicht in de oorzaken en gevolgen van werkloosheid en adequate beleidsreacties? Moeten we dieper graven en rekening houden met variatie in de zin dat we denken aan de specifieke besluitvormingscontext van burgers, de potentieel heterogene effecten van verschillende beleidsinstrumenten op hun welzijn en handelingscapaciteit, en de gevolgen van de wet wanneer burgers deze ervaren in hun interacties met de uitvoerende instanties? Tenslotte, welke rol speelt daarbij de in 2013 door Koning Willem-Alexander uitgeroepen participatiesamenleving die van iedereen die dat kan, vraagt om eigen verantwoordelijkheid te nemen voor zijn of haar leven en omgeving? 
Onderzoek naar de ervaringen van burgers met bijstand in andere landen, specifiek in het Verenigd Koninkrijk, heeft impliciete aannames in de beleidsvorming op losse schroeven gezet en de ontbrekende schakel tussen aannames en het beschikbare bewijsmateriaal aangetoond. Verkeerde aannames brengen het risico met zich mee dat het beleid niet voldoet aan de doelstellingen. Nog erger, het zou zelfs tot schadelijke effecten kunnen leiden waar geen rekening mee is gehouden of die zich voordoen op gebieden die mogelijk zijn verwaarloosd. Tegen deze achtergrond draagt dit onderzoek bij tot het aanpakken van bestaande onderzoeklacunes door middel van:

(1) een expliciete verkenning van de verbanden tussen aannames en beleidsontwikkeling, met behulp van een mixed-methods onderzoeksopzet en primaire dataverzameling;

(2) een analyse van de effecten van verschillende activeringsinstrumenten;

(3) een focus op uitkomsten die verder gaan dan de overgang naar regulier werk, specifiek het welzijn van individuen, inclusief hun sociale netwerk, en hun capaciteit om te handelen;

(4) aandacht voor de rol van zowel activeringswerkers en burgers, hun interacties, en hoe deze vorm geven aan de resultaten voor beleidsgebruikers.

\section{Onderzoeksopzet en -vragen}

Dit promotieonderzoek is gebaseerd op een pragmatisch wereldbeeld dat het onderzoeksprobleem centraal stelt en de methode kiest die het meest geschikt is om de onderzoeksvraagstelling te begrijpen. Een pragmatisch wereldbeeld creëert de mogelijkheid om meerdere methoden en verschillende vormen van dataverzameling en -analyse te gebruiken. Verder stimuleert het onderzoekers om na te denken over hoe en waarom ze keuzes maken met betrekking tot hun onderzoek en wat de gevolgen van hun keuzes zijn.

In de eerste plaats riep de schijnbare kloof tussen volksverhalen en retoriek aan de ene kant en de ervaringen van burgers die een bijstandsuitkering ontvangen aan de andere kant de vraag op welke aannames leidend moeten zijn voor de beleidsontwikkeling. Deze discrepantie zet ons aan om de besluitvormingscontext van mensen met een bijstandsuitkering (of de doelpopulatie in het algemeen) in detail te onderzoeken alvorens beleid uit te werken. Kwalitatieve methoden die gebruik maken van open vragen, in dit geval semi-gestructureerde interviews met 45 burgers 
in Maastricht, zijn geschikt om de ervaringen van individuen te begrijpen en hen hun eigen verhalen te laten samenstellen. Hierdoor is het mogelijk om complexe concepten te onderzoeken, zoals het welzijn en de handelingscapaciteit van een individu, die onder andere worden bepaald door de relatieve positie van het individu in de samenleving. Bovendien erkent deze benadering de unieke kennis en expertise van degenen die door het beleid worden beïnvloed en neemt deze kennis serieus. Hoofdstuk 2 en 3 behandelen de volgende vragen: Wat zijn de verbanden tussen verschillende activeringsinstrumenten en het welzijn en de handelingscapaciteit van burgers? Onder welke voorwaarden bevorderen activeringsinstrumenten het welzijn en de handelingscapaciteit, of beperken ze deze juist?

Het doel van de tweede fase van het onderzoek was om de verkregen inzichten te gebruiken om een instrument te ontwikkelen dat kan bijdragen aan het vergroten van het individuele welzijn en handelingscapaciteit, en dit instrument experimenteel te testen. Daarvoor werd een zelf-affirmatieve oefening toegepast. Dat is een procedure om het gevoel van eigenwaarde te beschermen, bijvoorbeeld door na te denken over belangrijke waarden en op te schrijven waarom deze belangrijk zijn. Dit deel van het onderzoek baseert zich op sociaal-psychologische theorieën. Aan de hand daarvan werden hypothesen ontwikkeld, verder onderbouwd met de belangrijkste aspecten en patronen die in de eerste fase werden gevonden. Om causaliteit vast te stellen en om veranderingen in het welzijn en de handelingscapaciteit van individuen toe te schrijven aan het nieuw ontwikkelde instrument werd voor een experimentele benadering gekozen. Samengevat worden in hoofdstuk 4 de volgende vragen onderzocht op basis van een onderzoek met een controlegroep met 174 bijstandsaanvragers en 15 activeringswerkers in Maastricht: Hoe kan een zelf-affirmatie worden geïntegreerd in de eerste afspraak van een burger die bijstand aanvraagt met een activeringswerker? In hoeverre levert de zelf-affirmatie de beoogde effecten voor burgers op, zoals een sterker gevoel van eigenwaarde, dat ze deel uitmaken van de maatschappij, minder stress ervaren tijdens het gesprek, een hogere inschatting maken van hun zelf-effectiviteit en een hogere cognitieve prestatie leveren?

De laatste onderzoeksfase onderzocht de besluitvorming van activeringswerkers en was gericht op het begrijpen van de principes die ten grondslag liggen aan de keuzes die activeringswerkers maken. Factoren die de besluitvorming van activeringswerkers beïnvloeden, zoals kenmerken van burgers, blijken vaak sterk gecorreleerd met elkaar. In een experimentele setting zou het mogelijk zijn om ervoor te zorgen dat verschillende factoren niet met elkaar gecorreleerd raken. Dit gaat echter meestal gepaard met de prijs dat er niet veel factoren in aanmerking kunnen worden 
genomen. De oplossing voor dit onderzoek werd gevonden in het gebruik van een factorial survey experiment, een methode die een multidimensionaal experimenteel ontwerp binnen een enquête implementeert. Net als in de vorige onderzoeksfase diende de verkennende fase als input voor het ontwerp van het factorial survey experiment, maar ook als referentie voor het contextualiseren van de resultaten. Het doel van hoofdstuk 5 is dan ook een systematische verkenning van de volgende vraag, waarbij gebruik wordt gemaakt van een factorial survey experiment onder 53 activeringswerkers in Maastricht: In welke mate zijn activeringswerkers het eens in hun besluitvorming en delen ze gezamenlijke normen? In welke mate weerspiegelen meningsverschillen in de besluitvorming verschillende interpretaties van de rol van activeringswerkers?

\section{Betekenis en Implicaties van Onderzoeksresultaten}

Welke betekenis en implicaties hebben de resultaten van dit onderzoek? Dit kan worden samengevat in negen reflecties die de link leggen tussen empirisch onderzoek en maatschappelijke betekenis.

\section{De weg naar een participatiesamenleving leidt niet noodzakelijk naar} een inclusieve samenleving. In 2013 kondigde Koning Willem-Alexander aan dat de klassieke verzorgingsstaat vervangen zou worden door een participatieve samenleving. In een participatieve samenleving wordt iedereen die daartoe in staat is, gevraagd verantwoordelijkheid te nemen voor zijn of haar eigen leven. Sommige critici waarschuwden voor mogelijk negatieve effecten van deze retoriek. Moeilijke situaties, zoals het niet kunnen werken, kunnen te gemakkelijk worden toegeschreven aan persoonlijke mislukkingen in plaats van structurele problemen. De realiteit van dit risico werd aangetoond in gesprekken met burgers die bijstand ontvangen. Individuen maken voortdurend vergelijkingen, of het nu gaat om de huidige situatie in relatie tot het verleden, of in relatie tot de ervaringen van anderen. Vanaf het begin brengt het leven met een bijstandsuitkering voor mensen het risico van verschillende vormen van uitsluiting met zich mee: uitsluiting van productieve processen, maar ook uitsluiting van zinvolle persoonlijke relaties, bijvoorbeeld als gevolg van beperkte financiële middelen. Een retoriek die de nadruk legt op persoonlijke verantwoordelijkheid, in combinatie met een beleidsontwerp dat bescherming biedt tegen (en daardoor impliciet uitgaat van) een gebrek aan motivatie en onverantwoorde keuzes, kan deze risico's gemakkelijk verergeren. De vormgeving van beleid moet niet alleen worden beoordeeld in het licht van de directe doelstellingen die 
het wil bereiken (in dit geval het verhogen van de arbeidsparticipatie), maar het moet ook rekening houden met de maatschappelijke dynamiek die het creëert. De huidige opzet van de Participatiewet heeft aantoonbaar de bredere maatschappelijke implicaties die deze wet met zich meebrengt verwaarloosd, namelijk dat een groep individuen het risico loopt verder te worden uitgesloten, omdat niet-deelname gelijkgesteld kan worden met onwil om bij te dragen aan de samenleving.

De termen activering en eigen verantwoordelijkheid en hoe deze worden gebruikt, moeten kritisch worden heroverwogen. De term activering zit vol met aannames, zoals in de inleiding en hoofdstuk 3 is geschetst. Uit de interviews blijkt dat burgers juist met deze implicaties worstelen. Zo wordt verondersteld dat zij zich onverantwoordelijk gedragen en dat hun gedrag moet worden gestuurd. Of het verhaal dat zij passief zijn of passief zijn geworden en in beweging moeten worden gebracht. Het is veelzeggend dat respondenten in hun verhalen de nadruk legden op de manier waarop ze actief zijn, de domeinen in hun leven die voor hen belangrijk zijn en hoe ze daarin handelen. Dit gaat veel verder dan het hebben van betaald werk. Activiteiten en verantwoordelijk gedrag werden benadrukt met betrekking tot het zijn van een goede ouder, een bezorgde verzorger, een betrouwbare vriend, een creatieve vrijwilliger. Op die manier zochten mensen naar alternatieve manieren van "actief burgerschap" (Garthwaite, 2017, p. 283). Nochtans, waren zij ook soms van mening dat deze activiteiten niet werden beschouwd toen zij werden "geëvalueerd", zij het bij de Sociale Dienst of in sociale interacties. Daarom moet het heroverwegen van die termen uitgaan van de veronderstellingen die worden gemaakt over gedrag en rekening houden met de connotaties die die termen met zich meebrengen. Het is van cruciaal belang om te erkennen dat activering geen neutrale term is.

Ook het gebruik van de term verantwoordelijkheid moet worden heroverwogen Wat betekent het eigenlijk in deze debatten? Eriksen (2019) beweerde dat het normaliter meer een begrip is dat de verwachtingen duidt ten aanzien van burgers met betrekking tot een grotere economische zelfredzaamheid en arbeidsmarktparticipatie. Wat blijkbaar in de discussies van vandaag tot verwarring leidt, zijn de domeinen waarnaar het verwijst. Is het de discussie over de economische of de maatschappelijke actor? Immers, ook al verwijst de activerings- en verantwoordelijkheidsretoriek alleen maar naar de economische actor, met name in hoofdstuk 3 is gebleken dat dit ook voor de maatschappelijke actor belangrijke gevolgen kan hebben. Dit wordt geillustreerd door het ontstaan of versterken van bestaande scheidingslijnen in de samenleving, waardoor individuen in verlegenheid worden gebracht en het gevoel van eigenwaarde en persoonlijke integriteit van mensen wordt aangetast. 
Wij moeten een expliciete discussie voeren welk werk in de maatschappij wordt gewaardeerd. In hoofdstuk 2 wordt geïllustreerd hoe sociale uitsluiting het resultaat kan zijn van werkloosheid, aangezien dit betekent dat mensen van productieve processen worden uitgesloten. In hoofdstuk 3 wordt geïllustreerd dat burgers gedemoraliseerd kunnen raken omdat het werk dat zij verrichten niet als reguliere arbeid kan worden aangemerkt. Dit omvatte vrijwilligerswerk of het verkennen van mogelijkheden om zelfstandig te gaan werken. Axel Honneth's definitie van werk, die alle activiteiten omvat die nodig zijn voor de reproductie van de samenleving, werd als alternatief aangeboden. In de toekomst zal deze discussie waarschijnlijk meer op de voorgrond treden. Technologische ontwikkelingen, zoals automatisering, digitalisering of kunstmatige intelligentie, hebben de wereld van het werk al veranderd en zullen dat blijven doen. Er worden nieuwe banen gecreëerd, terwijl andere overbodig worden. In haar onlangs gepubliceerde rapport heeft de Global Commission on the Future of Work (International Labour Office, 2019) een agenda opgesteld waarin de mens centraal staat. Elementen zijn verhoogde investeringen in de capaciteiten van mensen, in de instellingen van werk en in erkend en duurzaam werk. Maar deze onvermijdelijke veranderingen kunnen ook als kans worden gezien om de fundamentele discussie op gang te brengen over wat werk is en om ons perspectief ten aanzien van de definitie van werk te verbreden.

\section{De interactie tussen burgers en activeringswerkers heeft directe in- vloed op het welbevinden en de handelingscapaciteit, zowel positief als} negatief. De empirische hoofdstukken bestuderen deze interacties vanuit verschillende invalshoeken. De kwalitatieve studies identificeren een aantal voorwaarden die bijdragen tot positieve ervaringen van burgers. Burgers verwezen naar sociale en communicatieve vaardigheden van activeringswerkers, zoals benaderbaar, empathisch en respectvol, ondersteunend en motiverend. Ze wilden dat hun activeringswerkers hun persoonlijke situatie, omstandigheden en beperkingen begrepen en hen beschouwden als individuen met een uniek verleden, heden en toekomst. Het falen van de activeringswerkers om dit te doen kan leiden tot onthechting, frustratie en zelfs gevoelens van machteloosheid. Uit alle gesprekken resulteerde een cruciaal punt: Burgers willen als integraal lid van de samenleving worden gezien, vooral wanneer ze zich in een zeer kwetsbare situatie bevinden.

De bescherming van de persoonlijke integriteit van elk lid van de samenleving moet in de beleidsontwerpfase worden overwogen en gerespecteerd. Dit onderzoek heeft echter ook aangetoond dat er ruimte is om dit te doen buiten de schriftelijke wet- en regelgeving, namelijk in de interactie tussen burger en activeringswerkers. 
De in hoofdstuk 4 ontwikkelde en geteste zelf-affirmatieve oefening is hier een goed voorbeeld van. Het is een eenvoudige, gunstige oefening die het potentieel heeft om de zelf-effectiviteit van burgers te verhogen door hun persoonlijke integriteit te beschermen, waarbij zelf-effectiviteit een cruciale bouwsteen is voor een succesvolle zoektocht naar werk. De zelfbevestiging kan echter ook onbedoelde neveneffecten hebben voor sommige burgers, met name burgers die betere kansen op de arbeidsmarkt hebben. Voor hen heeft de zelf-affirmatie blijkbaar de dreiging om op bepaalde manieren beoordeeld te worden (d.w.z. deel uit te maken van een groep die verondersteld wordt de samenleving te bedriegen of onverantwoordelijk te handelen) niet verminderd. In tegendeel, ze heeft kennelijk extra aandacht besteed aan hun huidige situatie, namelijk dat ze tot deze potentieel gestereotypeerde groep behoren. De belangrijke les is dat verschillende burgers verschillende behoeften hebben en dat maatwerk nodig is om aan deze verschillende behoeften tegemoet te komen. Tegelijkertijd moeten de beslissingen van activeringswerkers gebaseerd zijn op bewijs. Anders bestaat het risico dat besluiten willekeurig en ondoorzichtig worden. Dit onderwerp werd aan de orde gesteld in hoofdstuk 5, waarin werd besproken in welke mate de beslissingen van activeringswerkers gebaseerd waren op de kenmerken van de burger, de kenmerken van de functie, maar ook de individuele kenmerken van de activeringswerkers en de verschillen in rolbegrip.

Een professionele identiteit van medewerkers in het activeringsdomein moet nog worden bediscussieerd en ontwikkeld. Zoals eerder opgemerkt door andere auteurs, is het domein van het activeringswerk divers. Het gaat hierbij om vrijwel alle aspecten waaraan gedacht kan worden, zoals job design, doelgroep, of kennis, opleiding en training van activeringswerkers. Zelfs binnen één organisatie was de steekproef van activeringswerkers divers. Ze verschilden in vooropleiding en in de manier waarop ze hun rol, d.w.z. het hoofddoel van hun werk, begrepen. In het algemeen werd duidelijk dat wat de activeringswerkers op dit moment verenigt, het feit is dat ze dezelfde taak doen, en niet dat ze noodzakelijkerwijs dezelfde normen en waarden delen. Met name tegen de achtergrond van de lopende organisatorische veranderingen in Maastricht Heuvelland, is er zowel een noodzaak als een kans om te bespreken welke waarden de kern van het activeringswerk vormen/zouden moeten vormen.

De manier waarop activeringswerkers hun rol begrijpen beïnvloedt hun besluitvormingsproces en uiteindelijk de kansen en beperkingen voor burgers. Het belang van deze stelling werd aangetoond en gekwantificeerd in een factorial survey experiment, beschreven in hoofdstuk 5. Activeringswerkers hebben 
verschillende ideeën over wat hun werk inhoudt. Het is niet verrassend dat deze ideeën van persoon tot persoon en van groep tot groep verschillen, bijvoorbeeld in de zin van teamlidmaatschap. Het punt is echter dat deze kaders van belang zijn voor de behandeling van burgers, ook al wordt er gecontroleerd op basis van persoonskenmerken van burgers, de educatieve en sociaaleconomische achtergrond van activeringswerkers en hun teamlidmaatschap of job design. Alhoewel al deze zaken gelijk waren, hing de beslissing om al dan niet gebruik te maken van een faciliterend instrument, in dit geval arbeidsbemiddeling, in belangrijke mate af van de vraag of een activeringswerker meer geneigd was om te begrijpen dat hij of zij de re-integratie moest bevorderen, of dat hij of zij zichzelf overwegend als dienstverlener zag. Lipsky (1980) zei dat de manieren waarop uitvoerende ambtenaren al dan niet voordelen realiseren of sancties opleggen, het leven en de kansen van mensen beïnvloeden (p. 4); zij vormen een belangrijke dimensie van burgerschap (p. 4). Dit spoort ons aan om na te denken en te discussiëren over deze factoren die van invloed zijn op de levering van voordelen en sanctionering. De resultaten van het factorial survey experiment dat het effect van verschillende factoren liet zien en hun relatieve belang kwantificeerde, is een belangrijk referentiepunt voor dergelijke discussies.

De vraag in hoeverre er verschillende waarnemingen van en referentiepunten voor rijke en arme mensen zijn, voor mensen met en zonder werk, en de oorzaken en gevolgen ervan, verdient meer aandacht. Het Sociaal en Cultureel Planbureau (SCP) heeft enkele jaren geleden onderzoek gedaan naar de rol van meer eigen verantwoordelijkheid in de Nederlandse beleidsvorming. Een deel van het onderzoek onderzocht de persoonlijke verantwoordelijkheid van individuen om in hun eigen onderhoud te voorzien (van Echelt \& Josten, 2012). Naast het re-integratie beleid werd ook gekeken naar het beleid om de inzetbaarheid van werknemers op de arbeidsmarkt te verhogen. Dit bood een vergelijkend perspectief op beleid voor mensen met en zonder werk. De auteurs concluderen dat het beleid voor deze laatste groep erg prescriptief is, wat een duidelijk verband aangeeft tussen rechten en plichten. Ze merkten echter ook op dat er meer wantrouwen werd geuit ten aanzien van werklozen - overigens niet alleen in de wet, maar ook in representatieve opiniepeilingen. De respondenten waren bijvoorbeeld voorstander van strengere toepassingsvereisten. Dit brengt ons terug naar het uitgangspunt van dit proefschrift, namelijk de alomtegenwoordigheid van de veronderstellingen. Het risico bestaat dat, hoe meer wantrouwen er in een wet geschreven wordt ten aanzien van de ontvangers van bijstand, hoe meer deze visie in de maatschappij verankerd raakt en vice versa. Er moet een breder besef komen dat de besluitvorming van de mensen die in armoede leven gedeeltelijk een gevolg is van onze maatschappelijke architectuur, de manier 
waarop de samenleving is opgebouwd (vgl. Sheehy-Skeffington, 2015). Als dit niet wordt erkend, is het waarschijnlijk dat oplossingen voor structurele ongelijkheden nog steeds op individueel niveau worden gezocht (vgl. Edmiston, 2018).

Een meritocratie is geen oplossing ... Het idee dat iedereen in de samenleving gelijke kansen heeft en dat het alleen de inspanning is die bepaalt in hoeverre iemand kan deelnemen, is misleidend. Ook dit lijkt een nogal individualistische visie te zijn die voorbijgaat aan het feit dat de vergelijking "merit = intelligentie + inspanning" meer willekeurige en structurele effecten bevat dan vaak wordt erkend. Op basis van een vergelijking tussen sociale klassenscheidingen en de scheidingslijnen die ontstaan zijn door het idee van meritocratie, stelde Adamson (2018) dat we het idee moeten herleven dat alle mensen van gelijke waarde zijn en dat een rechtvaardige samenleving er een is die de mogelijkheid van levenstevredenheid, in al haar variëteiten, openstelt voor al haar leden (paragraaf 58). In de context van dit onderzoek zou ik de stelling willen herformuleren door te zeggen dat een rechtvaardige samenleving een samenleving is die de wezenlijke vrijheid voor al haar leden openstelt om een leven te leiden waarin zij zich als waardige mensen kunnen voorstellen - niet alleen in termen van economische output, maar rekening houdend met het volledige scala aan activiteiten die bijdragen aan ons eigen welzijn, maar ook met activiteiten die bijdragen aan onze samenleving, zoals bevalling, zorg voor kinderen of ouderen, vrijwilligerswerk, of opleiding en educatie (vgl. Axel Honneth, genoemd in Schweiger, 2013, p. 544).

... maar misschien een basisinkomen? Dat hangt ervan af, zoals de econoom zou zeggen. Basisinkomen is de laatste jaren een begrip geworden (vgl. De Wispelaere \& Haagh, 2019), ook al is het idee helemaal niet nieuw. De discussie rondom het basisinkomen is niet altijd geleid met de conceptuele helderheid die het verdient. Het hangt af van het concrete ontwerp van een basisinkomen (vgl. Ortiz, Behrendt, Acuña-Ulate, \& Nguyen, 2018) in hoeverre het beleid kan zijn dat een positief effect kan hebben op het welzijn, de handelingscapaciteit en de sociale inbedding van burgers. In plaats van te pleiten voor een specifieke oplossing, is mijn belangrijkste zorg en doel van dit onderzoek dat beleidsmakers, eerstelijnswerkers en de maatschappij in het algemeen zich meer bewust worden van de terminologie die wordt gebruikt en wat die veronderstelt, de veronderstellingen die ten grondslag liggen aan het ontwikkelen van beleid en de gevolgen van het daadwerkelijke beleid. Met deze factoren moet rekening worden gehouden bij het ontwerpen van beleid dat gericht is op het aanpakken van sociale onrechtvaardigheden. 


\section{Referenties}

Adamson, P. (2018, September 27). Long read: The merit trap. Retrieved December 18, 2018, from https://newint .org/features/long-read/2018/09/27/ long-read-merit-trap-ability-and-heritability

De Wispelaere, J., \& Haagh, L. (2019). Introduction. Basic income in European welfare states: Opportunities and constraints. Social Policy $\&$ Society, 18(2), $237-242$.

Edmiston, D. (2018). The poor "sociological imagination" of the rich: Explaining attitudinal divergence towards welfare, inequality, and redistribution. Social Policy \& Administration, 52(5), 983-997.

Eerste Kamer der Staten-Generaal. (2014, June 24). Behandeling Participatiewet en Wet werk en bijstand. Retrieved February 19, 2019, from https://www.eerstekamer.nl/verslagdeel/20140624/ participatiewet_en_wet_werk_en_3

Eriksen, A. (2019). Reclaiming responsibility: The case of welfare-to-work policy. Journal of Social Policy, 48(3), 529-546.

Garthwaite, K. (2017). 'I feel I'm giving something back to society': Constructing the 'active citizen' and responsibilising food bank use. Social Policy $\&$ Society, 16(2), 283-292.

International Labour Office. (2019). Work for a brighter future - Global Commission on the future of work. Geneva, Switzerland: ILO.

Lipsky, M. (1980). Street-level bureaucracy: The dilemmas of the individual in public service. New York, NY: Russell Sage Foundation.

Ortiz, I., Behrendt, C., Acuña-Ulate, A., \& Nguyen, Q. A. (2018). Universal Basic Income proposals in light of ILO standards: Key issues and global costing. ESS - Working Paper No. 62, Social Protection Department, International Labour Office.

Schweiger, G. (2013). Recognition and social exclusion. A recognition-theoretical exploration of poverty in Europe. Ethical Perspectives, 20(4), 529-554.

Sheehy-Skeffington, J. (2015). Behavioural insights in the age of austerity: How the new 'psychology of poverty' can help us to stay focused on society. Angle Journal, 13. Retrieved October 21, 2016, from https://anglejournal.com/article/2015-12-behavioural-insights-in -the-age-of-austerity-how-research-on-the-psychology-of-poverty -can-help-us-to-stay-focused-on-so/ 
van Echelt, P., \& Josten, E. (2012). Werken voor je geld. In V. Veldheer, J.J. Jonker, L. Van Noije, \& C. Vrooman (Eds.), Een beroep op de burger. Minder verzorgingsstaat, meer eigen verantwoordelijkheid? (pp. 95-115). The Hague, the Netherlands: Sociaal en Cultureel Planbureau. 



\section{Valorisation Addendum}

This thesis was designed in light of the observation that what has often been missing in debates leading to and following the enactment of the 2015 Participation Act, which set out to harmonise a number of laws and increase labour participation, including for groups that face physical or psychological constraints, has been the point of view and the experiences of social assistance recipients. Assumptions have been made regarding their motivation, goals or skills. Subsequently, these assumption have informed discussions on as well as the final design of the Participation Act. Yet, do these assumptions hold? If not, what does this mean for social assistance recipients - both in relation to the effectiveness of policies to support them to reintegrate into the labour market, and with regard to their well-being? I argue that this thesis has had societal impact not only in terms of the results that were created and disseminated, but also with regard to the process of how knowledge was generated in interaction with citizens and employees at the Social Services Maastricht Heuvelland.

First, this thesis provides valuable insights into how Dutch citizens experience living with a social assistance benefit. The way this thesis was designed puts citizens on centre stage and, in this fashion, deviates from a large part of the literature on the effectiveness of activation policy. Commonly, researchers and policymakers aim to make the impact of an activation policy quantifiable by looking at the number of recipients that leave a social assistance or unemployment scheme within a certain timeframe, and by trying to establish whether the outflow can be attributed to this policy. Yet, there are important dimensions beyond outflow - not only the quality and sustainability of jobs that citizens find, which is another aspect that still deserves further attention - but the well-being of citizens while they receive social assistance benefits. Moreover, this thesis does not only look at the individual citizen, but at how citizens form a society. This thesis provides important impetus to move away from an overly exclusive focus on the individual and his or her responsibility and to reconsider the respective rights and obligations of the citizen and the state. It sensitises policymakers, people working at the frontline, and the society at large to the impact that terminology and policy design can have on people's lives, and advocates for dignity-promoting policies.

Second, the results of this thesis are valuable for the Social Services Maastricht Heuvelland. They obtained detailed insights into how citizens experience living on 
social assistance, including in relation to the policy instruments of the Social Services and to their interactions with caseworkers. For example, the satisfaction of social assistance applicants with the intake meeting (the first longer meeting with a caseworker) was explored, as well as their satisfaction with the services in the weeks after the intake. Sharing these results with the management team and caseworkers, and pointing towards leverage points for improvement and consideration, can contribute to improved services for citizens in the future. This is relevant in order to find more effective ways to support reintegration into the labour market and to promote citizens' well-being and capacity to act while they receive benefits.

In this way, the results of the studies were continuously used to provide concrete recommendations for the Social Services office and its employees. One example is the self-affirmative exercise that was developed and can be used by activation workers in intake meetings and potentially other meetings as well. If carefully applied, it has the potential to boost job search behaviour self-efficacy of social assistance recipients, which is an important building block for finding work. Additionally, the self-affirmation sensitises activation workers to the considerable challenges that accompany applying to and living on social assistance benefits not only financially, but also psychologically. Applications beyond the social assistance scheme are conceivable as well, for instance in relation to debt counselling or when working with young people. Another example was the importance of taking into account the complexity of the circumstances of social assistance recipients, who often have to juggle many tasks in addition to finding work. Acknowledging the mental effort that this involves, and comparing it to their own experience of stressful situations, can assist caseworkers in developing a more compassionate approach. These results could be incorporated explicitly into trainings for caseworkers. In fact, such training has to a large extent already been developed in the form of a workshop that was conducted with caseworkers to train them for the field experiment. The workshop introduced the results of the studies on how citizens experience living on social assistance in order to explain the rationale of the self-affirmation exercise. Based on the detailed protocol that was developed for the experiment, caseworkers could practice the use of this exercise in small groups during the workshop. The workshop materials could also be easily adapted to be included in other training or to form the basis for a day-long workshop that provides more room for reflection, for a toolbox of evidencebased practice, or as a basis for working with different target groups.

A further angle was added by providing insights into the role of caseworkers in the activation process that, contrary to other professions, is still being developed. 
On top of broader discussions at a national level (for instance led by the Dutch knowledge institute on social issues, Movisie (e.g. Spierts \& van Rest, 2017), or the association of Dutch caseworkers, BvK (e.g. Polstra \& Bakker, 2017)), Social Services Maastricht Heuvelland has gone through several transformations over the past years. Currently, a large project is underway that aims to put citizens at the heart of its work. According to the Social Services office's vision for the future, this requires, along with organisational changes, changes in caseworkers' attitude, behaviour and culture (Sociale Zaken Maastricht Heuvelland, 2018). This thesis thereby responded to current needs and questions of the Social Services office in several ways. It set the work of caseworkers in relation to how citizens experience activation policy and how it can affect citizens' well-being and agency; it developed a self-affirmative instrument adapted to the local context that could also be used for facilitating reflection processes on the part of caseworkers; and it provided an initial quantification of the relative importance of different factors on caseworkers' decision-making. Concretely, the Social Services office were recommended to use these results to initiate discussions among activation workers, for example during a workshop, regarding their role understanding in the context of the demands that are put on them by the written law, the organisational context (such as budget considerations and internal targets), and their own convictions.

Third, an important element was that this thesis did not only produce results for the Social Services, but with them. The early involvement of the Social Services office during all stages of the research not only facilitated but also made these studies possible in the first place. The direct interactions with employees, in the form of formal and informal talks and meetings, presentation of results and workshops, have also created awareness among both the management and activation workers of how social assistance recipients experience activation policies and what this means for policy design and implementation. The development of the self-affirmative exercise in cooperation with the Social Services office guaranteed that it fitted current work processes and consequently could be directly implemented without further adjustments. Ample attention was given to create support at the working level by convincing activation workers about the potential benefits - in addition to the support from the senior level of the organisation, i.e. the management. Equally, the content of the factorial survey experiment was developed in close collaboration with activation workers, quality assurance employees and team managers, in order to reflect their day-to-day decision-making as closely as possible.

Fourth, an objective of all studies was to think about the conditions under which 
different policy instruments worked or did not work. By analysing the effects of different types of activation instruments, and by taking into account heterogeneous responses of citizens, it is possible to reflect to what extent these results would carry over to other contexts. This could include, for instance, different types of meetings, other municipalities, or various target groups. External validity, that is, the extent to which the results of a study are valid beyond the specific study context, is a particular concern for policymakers, who need to understand and decide whether these results have implications for their own organisation. In the Dutch reintegration context, municipalities are asked to uniformly implement a number of obligations for citizens, such as work and reintegration obligations, or a quid pro quo requirement as applicable. Beyond that, however, municipalities have important leeway with regard to the reintegration activities that they offer. It is thus crucial to discuss the effects of specific instruments, as undertaken in this study, so that policymakers or frontline workers in other municipalities can reflect on their relevance and feasibility in their own organisation. Moreover, the results are relevant beyond the borders of the Netherlands, as activation policies have gained particular prominence in most countries of the Organisation for Economic Development and Co-operation (OECD) since the mid-1990s. Beyond that, the results may also speak to developing and emerging countries, where interest in combining anti-poverty policies with supporting individuals in finding more sustainable income sources has increased as well (Malo, 2018). As there has recently also been more attention paid to the experience of shame and stigma in the context of anti-poverty programmes, as well as their potential to increase dignity, this thesis provides interesting leverage points to consider for both research and policymaking in these contexts (Roelen, 2017).

At all stages of the thesis, results were disseminated widely with different audiences and in appropriate formats. For example, results were shared with study participants and Social Services Maastricht Heuvelland in the form of policy briefs and reports, as well as in the form of presentations to the management team of Social Services Maastricht Heuvelland. In addition, I plan to further explore the extent to which results can be shared more widely with networks of activation workers and managers in the Netherlands. On the academic side, I have presented papers at international conferences, including at the International Conference on Welfare Conditionality (2018), the Human Development and Capability Association Annual Conference (2016) and the Association for Public Policy Analysis \& Management International Conference (2016). Furthermore, I plan to publish the studies in international, peer-reviewed journals. Finally, the experimental data will be shared with the research community to ensure that results can be replicated. 


\section{References}

Malo, M. Á. (2018). Finding proactive features in labour market policies: A reflection based on the evidence. ILO Future of Work Research Paper Series, 8 .

Polstra, L., \& Bakker, H. (2017). De kern van het beroep van klantmanager. Utrecht, the Netherlands: Beroepsvereniging voor Klantmanagers.

Roelen, K. (2017). Shame, poverty and social protection. IDS Working Paper, 489.

Sociale Zaken Maastricht Heuvelland. (2018). Van droom tot werkelijkheid. Samen doen! Maastricht, the Netherlands: SZMH.

Spierts, M., Marcel en van Pelt, \& van Rest, S., Evert en Verweij. (2017). Visie en vakbekwaamheid maken het verschil. Utrecht, the Netherlands: Movisie. 



\section{About the Author}

Mira Bierbaum, born in 1986 (Ulm/Donau, Germany), holds a bachelor's degree in Politics and Public Administration from Konstanz University (BA, 2010) and a master's degree in Public Policy and Human Development from Maastricht Graduate School of Governance (MGSoG)/United Nations University (UNU) with a specialisation in Social Policy Design and Financing (MSc, 2012). In 2012, Mira joined the research group on Social Protection, Inclusive Innovation and Development at MGSoG/UNU-MERIT as a research assistant. In 2013, she joined the Joint PhD programme in Economics and Governance at UNU-MERIT and the MGSoG.

Mira has experience with poverty and vulnerability assessments and the assessment of the effectiveness and efficiency of social protection systems using large household data sets. She taught advanced classes on quantitative methods in poverty analysis, the analysis of social protections systems and impact evaluation. Additionally, Mira worked as a consultant for the World Bank on projects in the Kyrgyz Republic, Tajikistan and Russia. Since 2015, in cooperation with the FriedrichEbert-Stiftung and the Global Coalition for Social Protection Floors, she has been involved in developing and then updating an indicator that measures the extent to which countries have implemented a social protection floor. In a related project, she recently prepared a costing analysis for UN Women's 2019 flagship report Progress of the World's Women.

Mira currently works in the Social Policy Unit of the International Labour Organization's Social Protection Department. 